\title{
Leonardo Egas
}

\section{Análise pluridimensional da sustentabilidade do ciclo de vida de um sistema estrutural de cobertura em madeira de Pinus. Caso: Assentamento rural Pirituba II.}

Dissertação apresentada à Escola de Engenharia de São Carlos da Universidade de São Paulo como parte dos requisitos para obtenção do Título de Mestre em Arquitetura e Urbanismo.

Orientadora: Profa. Dra. Akemi Ino 
A Lívia, que transformou minha vida com seu amor A meus pais e irmãos por serem uma base firme na qual sempre pude me apoiar 


\section{Agradeço,}

À Akemi, pela orientação, companheirismo e por me mostrar um objetivo pelo qual vale a pena lutar.

Ao Prof. Shimbo, pelas ajudas e orientações.

À Lívia, por ter me acompanhado em todos os momentos difíceis, sempre me ajudando, incentivado e mostrando o objetivo da vida para que eu nunca desanimasse.

A todos os amigos do grupo Habis que me acompanharam nesses anos, especialmente: Fernando, Tati, Melissa, Carol, Ivan, Albenise, Mauricio e Nagui, que tanto contribuíram com a minha formação acadêmica e profissional.

A todas as famílias do Assentamento Rural Pirituba II, que me despertaram para um mundo que eu não conhecia, em especial: Bete, Cida, Doraci e Sebastiana.

Ao engenheiro florestal Ronaldo e gerente Aguinaldo pelas preciosas informações cedidas.

A todos os funcionários do departamento de Arquitetura e Urbanismo que me auxiliaram durante esse período.

À FAPESP pelo provimento da bolsa, que permitiu a o desenvolvimento desse trabalho de forma satisfatória.

A Deus, por me fazer olhar para essa caminhada com alegria e prazer. 
"O homem consciente luta pela participação politica e trabalha para despertar novas consciências, pois o aumento do número de participantes será a grande força, capaz de eliminar as injustiças e restaurar a dignidade bumana".

Dalmo de Abreu Dallari. 
EGAS, L. (2008) Análise pluridimensional da sustentabilidade do ciclo de vida de um sistema estrutural de cobertura em madeira de Pinus. Caso Assentamento Rural Pirituba II. Dissertação (Mestrado) - Escola de Engenharia de São Carlos, Universidade de São Paulo, São Carlos, 2008.

O trabalho está inserido no debate dos sistemas construtivos mais sustentáveis, procurando analisar a forma como a construção civil está atuando atualmente e propondo alternativas para minimização de seus impactos. Nas últimas décadas esse tema vem sendo abordado de forma parcial, com proposições de novas tecnologias, sem no entanto avançar nos estudos que procuram avaliar as complexas relações existentes na realidade para resolução desses problemas. As práticas sociais, econômicas, políticas e culturais, normalmente não abordadas na maioria dos estudos, muitas vezes são causadoras dos atuais níveis de consumo e produção de resíduos e emissões, devendo ser necessariamente estudadas de forma indissociável às questões tecnológicas e ambientais e em relações de ganhos e perdas de sustentabilidade, para que então se proponham novos sistemas construtivos e procedimentos, capazes de trazer um cenário mais sustentável em determinado contexto e dimensão. O objetivo do trabalho é levantar e analisar os pontos de maior e menor sustentabilidade do ciclo de vida do sistema estrutural de cobertura em vigas laminadas pregadas de madeira de Pinus de $3^{a}$ qualidade, nas dimensões ambiental, social, econômica, política e cultural, avaliando suas relações de ganhos e perdas ao longo do processo. O trabalho dividiu-se em duas grandes etapas, sendo que na primeira foi feita uma revisão bibliográfica, levantando os atuais métodos de sustentabilidade e identificando seus limites e potencialidades, na qual constatou-se que nenhum estudo abrangia as diferentes dimensões de forma satisfatória, concentrando-se apenas na ambiental. Em seguida, para se aproximar de uma análise pluridimensional de forma satisfatória, escolheu-se a Avaliação do Ciclo de Vida (ACV) como método mais indicado, associando-o aos Indicadores Ethos, a outras variáveis levantadas da literatura e a uma nova ferramenta criada para organização e visualização dos dados, resultando no método proposto, a Avaliação Pluridimensional do Ciclo de Vida (APCV). Na segunda etapa aplicou-se o método desenvolvido em um estudo de caso único, o ciclo de vida do sistema estrutural em vigas laminadas pregadas produzido no assentamento rural Pirituba II, onde foram levantados os impactos gerados durante toda sua cadeia. Os resultados atingidos mostraram que a utilização da madeira em um processo de mutirão, com pré-fabricação em uma 
marcenaria coletiva, pode trazer impactos positivos, pois, além de ser um material renovável, é capaz de capturar do $\mathrm{CO}_{2}$ da atmosfera, gerar energia a partir de seus resíduos, gerar trabalho e renda e trazer melhorias na qualidade de vida dos mutirantes e da comunidade. O trabalho chega em uma análise de relações de ganhos e perdas da sustentabilidade, indicando os pontos de maior ou menor fragilidade nos processos e dimensões, possibilitando assim mudanças de postura frente a essas questões e auxiliando nas escolhas de sistemas construtivos mais sustentáveis.

Palavras chave: sustentabilidade, análise pluridimensional, ciclo de vida, sistema estrutural de cobertura, madeira de Pinus, método de análise da sustentabilidade. 
EGAS, L. (2008) Multidimensional sustainability analysis of a structural roof system life cycle made of Pinus wood. Case: Pirituba II Rural Settlement. Master Degree Dissertation Escola de Engenharia de São Carlos, Universidade de São Paulo, São Carlos, 2008.

This paper is enclosed in the discussion of a more sustainable building systems, seeking to study how the civil construction is acting out in the present time and offering alternatives to reduce its impacts. In the last decades this theme has been partially approached, with new technology propositions, however, without coming along with studies that assess the existing complex relations in the reality to solve these problems. The social, economical, political and cultural experiences usually not approached in most studies, mostly are the ones responsible for the current levels of consumerism and production of leftovers and emission, thus necessarily becoming the target of studies that connect them to the technical and environmental matters, regarding to the gains and losses of sustainability, to propose new building systems and procedures ables to bring up a more sustainable scenario in some contexts and dimension. The aim of this paper is to bring about and analyze the points of higher and lower sustainability in the structural roof system life cycle in nail-laminated wood beams made of $3^{\text {rd }}$ class quality Pinus, in the environmental, social, economical, political and cultural dimensions, assessing its relations of gains and losses along the process. The work was divided in two big steps, having the first one step a bibliography revision, collecting data about the current sustainable methods and identifying their limits and potentialities, where it revealed that no studies has covered the different dimensions in a satisfactory way, focusing only on the environment. Following, to become closer to an acceptable multidimensional analysis, the Life Cycle Assessment (LCA) was chosen as the most indicated method, connected to the Ethos Indicators, the other raised variables from the literature and the new tool created to organize and viewing the data, resulting in the proposed method, the Multidimensional Life Cycle Assessment (MLCA). In the second step, it was used the method developed in the singular case study, the life cycle of the structural system of naillaminated beams, developed in the Pirituba II Rural Settlement, where the impact generated across the chain was raised. The achieved results showed that the use of wood in a cooperative process, with prefabricated parts in the cooperative carpentry workshop can bring positive impacts, since it is a renewable resource and also capable to capture $\mathrm{CO}_{2}$ from the atmosphere, to generate energy from its leftovers, creating works and revenues hence bringing quality of life for 
workers and the community. The work progresses to the analysis of relations in the sustainability gains and losses, suggesting the points of major or minor fragility in the process and dimensions, thus allowing changes of posture facing these matters and helping out in the choices of more sustainable building systems .

Keywords: sustainability, multidimensional analysis, life cycle, structural roof system, Pinus wood, sustainability analysis method. 


\section{Sumário}

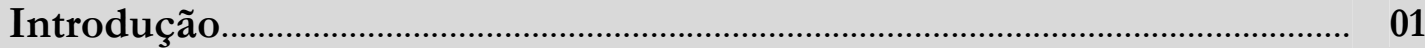

\section{Capítulo 1 Os conceitos da sustentabilidade e seus métodos de análise.... 07}

1.1. O conceito de sustentabilidade ................................................................................ 07

1.2. As divergências sobre o tema............................................................................ 11

1.3. As dimensões da sustentabilidade e suas diretrizes............................................. 15

1.4. Panorama dos métodos de análise da sustentabilidade e critérios para uma análise mais balanceada.

1.5. Escolha do método de análise da sustentabilidade........................................... 24

\section{Capítulo 2 Método de pesquisa..................................................................................... 29}

2.1 Perguntas, hipóteses e objetivos de pesquisa ........................................................ 30

2.2 Estratégia geral de pesquisa..................................................................................... 32

2.2.1 Revisão bibliográfica para elaboração do método de análise pluridimensional da

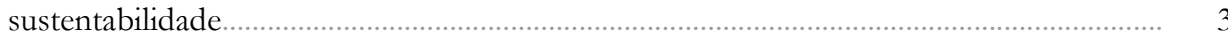

2.2.2 Aplicação do método de Avaliação Pluridimensional do Ciclo de Vida em um objeto

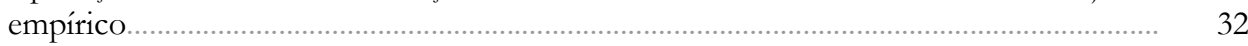

2.3 Apresentação do objeto de estudo...................................................................... 34

2.3.1 O processo de escolha da região de Itapeva e do assentamento Pirituba II como local

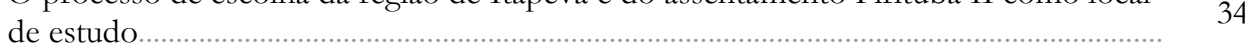

2.3.2 O assentamento Pirituba II e sua organização para construção das habitações............... 38

2.3.3 A escolha da arquitetura e dos sistemas construtivos........................................................ 40

2.3.4 Formação da marcenaria coletiva autogestionária .......................................................... 41

2.3.5 Descrição do sistema estrutural em Vigas Laminadas Pregadas......................................... 42

\section{Capítulo 3 Adaptação e aplicação do método de Avaliação do ciclo de} vida no sistema estrutural de cobertura em VLP............................ 49

3.1 Adaptação do método de avaliação do ciclo de vida visando um instrumento

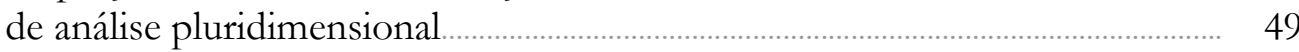

3.1.1. Estrutura do método de análise do ciclo de vida ............................................................ 50

3.1.2 Adaptação e ampliação da abrangência do método de avaliação do ciclo de vida para uma análise pluridimensional. 
3.2 Aplicação do método de APCV- Avaliação Pluridimensional do Ciclo de Vida na cadeia do sistema estrutural de cobertura em VLP.

3.3 Definição do objetivo e escopo do objeto de estudo ...................................................... 59

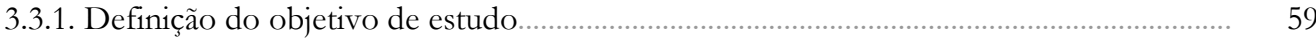

3.3.2. Definição do escopo do objeto de estudo........................................................................ 59

3.4 Análise do inventário do objeto de estudo ………………………………………... $\quad 72$

3.4.1 Descrição dos processos envolvidos na cadeia de produção da VLP ................................. 75

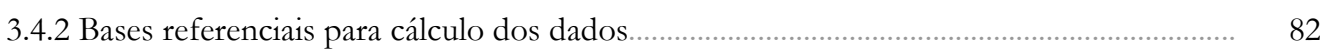

\section{Capítulo 4 Avaliação dos impactos do ciclo de vida do sistema estrutural em VLP.}

4.1 Seleção das categorias de impacto e modelagem dos dados de inventário por categorias de impacto.

4.2 Apresentação dos dados referentes à dimensão ambiental ..................................... 102

4.2.1 Entradas das matérias primas e geração de resíduos ............................................................ 102

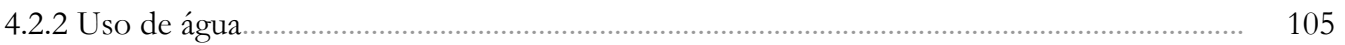

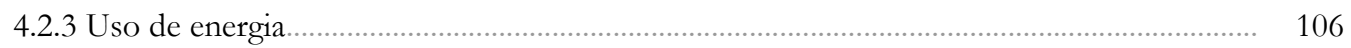

4.2.4 Emissão de poluentes ao ar, solo e água ....................................................................... 107

4.3 Apresentação dos dados da dimensão social............................................................... 110

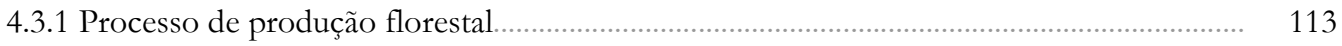

4.3.2 Processo de beneficiamento da madeira .............................................................................. 115

4.3.3 Processo de construção do sistema estrutural de cobertura ............................................... 117

4.4 Apresentação dos dados da dimensão econômica ..................................................... 121

4.4.1 Processo de produção florestal .......................................................................................... 121

4.4.2 Processo de beneficiamento da madeira …....................................................................... 124

4.4.3 Processo de construção do sistema estrutural de cobertura .............................................. 126

4.5 Apresentação dos dados da dimensão cultural .......................................................... 130

4.5.1 Processo de produção florestal ......................................................................................... 130

4.5.2 Processo de beneficiamento da madeira ….......................................................................... 130

4.5.3 Processo de construção do sistema estrutural de cobertura e operações de manutenção

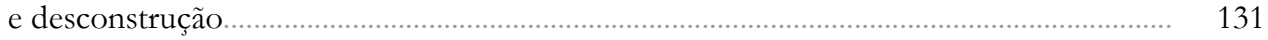

4.6 Apresentação dos dados da dimensão política ............................................................... 132

4.6.1 Processo de produção florestal ................................................................................................ 132

4.6.2 Processo de beneficiamento da madeira …........................................................................ 133

4.6.3 Processo de construção do sistema estrutural de cobertura e operações de manutenção e desconstrução

\section{Capítulo 5 Interpretação dos dados}

5.1 Identificação e análise das questões significativas 
5.2 Análise da dimensão ambiental ao longo do ciclo de vida do sistema estrutural em VLP.

5.3 Análise da dimensão social ao longo do ciclo de vida do sistema estrutural em VLP.

5.4 Análise da dimensão econômica ao longo do ciclo de vida do sistema estrutural em VLP.

5.5 Análise da dimensão cultural ao longo do ciclo de vida do sistema estrutural em VLP.

5.6 Análise da dimensão política ao longo do ciclo de vida do sistema estrutural em VLP

5.7 Análise das relações entre as dimensões do processo de produção florestal....

5.8 Análise das relações entre as dimensões do processo de beneficiamento da madeira

5.9 Análise das relações entre as dimensões do processo de construção.

5.10 Análise das relações entre as dimensões da operação de manutenção.

5.11 Análise das relações entre as dimensões da operação de desconstrução e disposição final..

5.12 Verificação da integridade e consistência do trabalho.

Capítulo 6 Considerações finais. 


\section{Introdução}

A necessidade de se atender o déficit habitacional de um país subdesenvolvido como o Brasil confronta-se com o debate da sustentabilidade, já que as escolhas dos materiais, dos sistemas construtivos e do processo para execução dos mesmos determinam a forma como a construção civil atua no Brasil e em todo o mundo, consumindo altos níveis de energia e gerando grande quantidade de resíduos e emissões.

Considerando as estatísticas da CIB (1999), as construções na União Européia são responsáveis por mais de $40 \%$ do consumo total de energia e estima-se que o setor da construção civil gere aproximadamente $40 \%$ de todo o lixo produzido pelo homem, além de ser responsável por cerca de 30\% das emissões de dióxido de carbono, contribuindo diretamente com as questões ambientais, como o aquecimento global, que põe em pauta as nefastas conseqüências da atual mudança de temperatura da Terra, e o esgotamento dos recursos naturais não renováveis, como os combustíveis fósseis e a água.

Também é importante ressaltar os padrões econômicos e sociais indicados pela qualidade de vida dos países subdesenvolvidos na atualidade, que segundo dados do World Resources Institute e UNDP (1990 apud SACHS, 1993) tem-se que grande parcela do mundo vive em condições miseráveis, impróprias para e reprodução da vida humana e registrou, em 1990, 25\% da população mundial com alimentação insuficiente, sendo que quase 1 bilhão de pessoas passavam fome, 1,5 bilhões não tinham acesso a água potável e o mesmo número não tinha nenhum acesso a serviços de saúde. Dados que se comparados aos índices de consumo de países desenvolvidos mostram o grande desequilíbrio do planeta, com grande concentração de riqueza e consumo na minoria da população mundial, enquanto a grande maioria não possui o suficiente para sobreviver, arcando ainda com os danos ambientais causados pela população rica, além dos gerados pela sua condição de existência.

Dentro desse quadro mundial, vê-se a necessidade de se buscar uma melhor forma de produzir habitações, atendendo não somente às diretrizes ambientalmente sustentáveis, mas considerando a pluridimensionalidade dessa questão. Surge então a necessidade de melhor definir o conceito de sustentabilidade nos contextos em que seja adotada como referência qualitativa, por se tratar de uma idéia condicionada por componentes genéricos, nem sempre consensuais ou universalizáveis, e assim poder explicar as bases sobre as quais se fundamentam a sua utilização 
(SILVA, S., 2000). Outros autores colocam as dificuldades de se definir sustentabilidade devido aos diferentes enfoques que podem ser dados por diferentes países. Por exemplo, países com economias em desenvolvimento podem dar mais prioridade à desigualdade social e econômica, enquanto países com economias maduras darão mais enfoque à criação de um mercado imobiliário mais sustentável, à invenção de novas tecnologias, à renovação e à questão ambiental.

Segundo Sachs (1993) a sustentabilidade vai muito além da dimensão ambiental, abordando em seu trabalho seu caráter interdisciplinar, buscando conceituá-la no que seria chamado de tripé da sustentabilidade: eficiência econômica, justiça social e prudência ecológica. O autor mostra a grande relação entre esses conceitos e como, ao se priorizar apenas um deles, pode-se estar criando uma deficiência em outro, e coloca a necessidade de se tratar o assunto de forma indissociável, abrindo um primeiro debate sobre o caráter pluridimensional. Essa visão adequa-se ao contexto dos países em desenvolvimento, à medida que não prioriza somente a questão ambiental como usualmente é feito em países cujo problema social está em grande parte resolvido.

Partindo-se dessa visão, é necessário colocar a discussão na realidade da construção civil, considerando-se o déficit habitacional que em 2005 era de 7,9 milhões (FUNDAÇÃO JOÃO PINHEIRO, 2007), e particularmente o déficit da habitação rural, responsável por 18,2\% - ou 1,48 milhões de novas moradias - dessa mesma estatística, que em termos relativos, equivale a 16,5\% dos domicílios particulares permanentes contra 14,5\% da área urbana.

Para se viabilizar uma análise de abrangência pluridimensional da sustentabilidade, dentro do tempo e recursos financeiros disponíveis para essa pesquisa, optou-se por estudar o ciclo de vida de apenas um dos sub-sistemas construtivos das habitações do Assentamento Rural Pirituba II (objeto empírico escolhido para o estudo de caso único), o sistema estrutural de cobertura, que representa um grande custo dentro do sistema de cobertura e que pode chegar a $20 \%$ do custo total de uma obra no caso das habitações sociais (SAVASTANO, 2001). Para a produção de seus componentes, foi implantada uma marcenaria coletiva autogestionária formada pelas famílias beneficiárias dessas moradias, que participaram ativamente dos processos decisórios, contribuindo para o aumento de sua autonomia e cidadania (SILVA, S., 2000), e dos processos de pré-fabricação do sistema de cobertura, possibilitando a continuidade do funcionamento da marcenaria coletiva após o término das moradias e gerando trabalho e renda para as famílias.

O sistema estrutural de cobertura proposto (com madeira de Pinus spp) tinha como condição principal a replicabilidade, para que fosse acessível ao maior número possível de pessoas, e foi 
uma inovação pensada para ser mais sustentável que o sistema tradicional de cobertura (que utiliza madeira nativa e um sistema estrutural de tesouras, terças, caibros e ripas), utilizando-se a madeira como material construtivo devido a diversos fatores:

- Abundância do material na região: somente na área de abrangência do pólo de plantios florestais de Itapeva concentram-se 61.660 ha equivalentes à maior concentração de plantios de Pinus spp do Estado de São Paulo com 38,9\% do total (GAVA, 2005).

- Qualidades inerentes ao material: reservas renováveis, produção de peças em diversas dimensões, trabalhável com ferramentas convencionais, reutilizável, resistente aos esforços de tração e bom isolante térmico e acústico (ARRUDA, 2000).

- Respeito à participação dos moradores: os moradores participaram ativamente das escolhas em todas as etapas da obra, inclusive no projeto e escolha dos materiais construtivos, a partir das quais puderam optar pela telha cerâmica com estrutura em madeira.

No atual cenário brasileiro da construção civil, os sistemas de cobertura comumente utilizados nas habitações são feitos com madeiras nativas provenientes das regiões norte e centro-oeste do país devido à sua baixa oferta nas regiões sul e sudeste, que tiveram suas florestas nativas reduzidas pelo uso não manejado (PINHEIRO, 1996), resultando no baixo grau de sustentabilidade dessa prática, tanto ambientalmente (causando grandes danos às florestas) como economicamente (alto custo de transporte). Os estudos para utilização de madeiras de plantios florestais em sistemas de cobertura ainda são muito pontuais e raramente abordam sua utilização em habitações sociais, enfocando na maioria das vezes em novos desenhos de estruturas, desenvolvimento de novos materiais ou na racionalização e/ou melhoramento das técnicas convencionais. Pinheiro (1996) realizou um estudo de sistemas estruturais de cobertura utilizando madeira de Pinus, contribuindo com o aumento do grau de sustentabilidade na dimensão ambiental ao se preocupar com a não utilização das madeiras nativas, porém não desenvolve inovações para que esses sistemas sejam acessíveis à população de baixa renda. Já em outros trabalhos desenvolvidos observa-se um avanço em relação ao tema da habitação social mais sustentável, como na dissertação de Arruda (2000) "Diretrizes para projeto arquitetônico de habitação social em Pinus spp produzida por mutirão", em que o autor coloca o Pinus spp de plantios florestais como um material capaz de responder às exigências do desenvolvimento sustentável, levantando o debate sobre o sistema do mutirão como processo de produção e destacando que esses programas atenderam até hoje, independentemente da forma de gestão, 
populações de baixíssima renda (nunca antes atendidas por qualquer programa de provisão direta de habitação à população), além de ser uma forma viável, rica, significativa e democrática de se produzir habitações, aproximando-se assim de um estudo que tende para a habitação mais sustentável, tanto do ponto de vista ambiental como do social.

No entanto, Arruda (2000) ainda acrescenta:

O trabalho não tem como objetivo a avaliação de projetos arquitetônicos para habitação social segundo essas classes de variáveis (se referindo às dimensões social e política), ainda que elas deverão ser consideradas sempre que possível. Neste momento, é importante apenas demonstrar que a utilização de madeira de plantios florestais é capaz de responder às exigências ambientais, por ser um recurso renovável e por consumir baixa quantidade de energia na produção de madeira serrada.

E Ino; Shimbo (1998), explorando mais algumas dimensões da sustentabilidade, colocam que “[...] para que determinada habitação seja mais sustentável, é preciso que ela responda de maneira mais favorável às dimensões ecológica, social, econômica e tecnológica” e, segundo Yuba (2005):

[...] as variáveis que determinam a sustentabilidade [observando os conceitos e seus princípios] têm relações tão intrincadas que se modificam continuamente, que se percebe que a análise baseada somente nos princípios da dimensão ambiental não reflete a sua complexidade, pois basicamente estabelece comparações entre características inerentes aos materiais ou produtos.

É nesse contexto que se insere o presente trabalho "Análise pluridimensional da sustentabilidade do ciclo de vida de um sistema estrutural de cobertura em madeira de Pinus. Caso: Assentamento Rural Pirituba II", que busca, através de um levantamento bibliográfico de trabalhos que discutem os métodos de análise da sustentabilidade, revisar e adaptar os mais indicados para uma análise em diferentes dimensões, vista a grande dificuldade de se definir qual é a melhor forma de se avaliar um sistema construtivo dentro das diretrizes da sustentabilidade. A partir da sua adaptação, o método será aplicado a um objeto de estudo, levantando e avaliando as variáveis que interferem nos processos de ganhos e perdas de sustentabilidade ao longo de seu ciclo de vida e entre suas diferentes dimensões, ambiental, social, econômica, cultural e política.

Busca-se assim, a criação de uma base referencial de sistemas e materiais construtivos, do ponto de vista pluridimensional da sustentabilidade, para que futuros trabalhos possam comparar 
diferentes experiências com mais clareza, permitindo escolhas mais conscientes para os profissionais da construção civil, contribuindo assim para a redução dos impactos que vêm criando no planeta Terra.

Para atingir os objetivos pretendidos o trabalho foi estruturado da seguinte maneira:

No capítulo 1 é feito um resgate histórico dos conceitos da sustentabilidade, elucidando as divergências que foram criadas ao longo dos anos de debate e como os diferentes posicionamentos frente ao problema resultaram em um conceito amplo e não consensual. É introduzida a idéia de pluridimensionalidade, onde se discute a indissociabilidade das questões ambientais das sociais, econômicas, políticas e culturais. Também são levantados os métodos de análise da sustentabilidade e feita uma avaliação de qual seria o mais adequado para uma análise pluridimensional no contexto brasileiro, considerando os seus limites e potencialidades, adotando-se a Avaliação do Ciclo de Vida como método que irá estruturar a incorporação de outras dimensões.

No capítulo 2 é explicado o método de pesquisa, esclarecendo o objetivo geral e específicos da pesquisa e as perguntas e hipóteses nos quais foram baseados. Em seguida é relatada a forma como o trabalho foi estruturado, suas etapas, os procedimentos de coleta de dados e de aplicação do método de avaliação do ciclo de vida sobre o objeto empírico para que se pudessem atingir os objetivos pretendidos. Por fim descrevem-se os processos de escolha do assentamento como local de estudo, do financiamento da habitação e da elaboração do projeto arquitetônico e escolha dos sistemas construtivos, apresentando o sistema estrutural de cobertura que será estudado e a marcenaria onde foi pré-fabricado.

No capítulo 3, o método escolhido para servir como base, a Avaliação do Ciclo de Vida, é adaptado, a partir das análises da literatura, e associado a outro método que aborda as questões sociais e econômicas, acrescentando-se ainda novos indicadores, retirados da literatura, para as dimensões política e cultural, que não eram abordadas por nenhum dos métodos levantados. Também são propostas novas ferramentas, para facilitar a organização e visualização dos dados a serem coletados e analisados, encerrando a etapa de adaptação do método existente, para chegarse então a um método de avaliação pluridimensional da sustentabilidade. Ainda nesse capítulo é apresentada a estrutura do método proposto, a Análise Pluridimensional de Ciclo de Vida (APCV), dividida em quatro fases, e a aplicação das duas primeiras, delimitação do objetivo e escopo e análise do inventário, no objeto de estudo. 
No capítulo 4 aplica-se a terceira fase do método proposto, onde são selecionadas e descritas as categorias de impacto das diferentes dimensões e apresentados os dados do inventário, já divididos em suas respectivas categorias, calculados e organizados em tabelas e gráficos, para dados quantitativos, e em forma de ponderações e textos, para dados qualitativos.

No capítulo 5 os dados apresentados serão usados como base para a análise dos impactos de cada dimensão da sustentabilidade ao longo do ciclo de vida e das relações entre as dimensões em um mesmo processo. Assim são levantados os pontos de maior e menor sustentabilidade do ciclo de vida e das relações ali existentes, concluindo a última fase do método proposto.

No capítulo 6 são elaboradas as considerações finais, salientando os pontos mais relevantes da análise feita, e sugerindo possíveis encaminhamentos para futuras pesquisas e ações. Também é feita uma análise de consistência do trabalho, procurando avaliar as limitações encontradas durante a pesquisa. 


\section{Capítulo 1}

\section{Os conceitos da sustentabilidade e seus métodos de análise}

Nesse capítulo discute-se a evolução dos conceitos de sustentabilidade e de desenvolvimento sustentável através de um resgate histórico das últimas décadas, mostrando como esses termos apresentam divergências conceituais para diferentes autores, que muitas vezes defendem uma visão que prioriza interesses específicos de determinados grupos e países.

Apresenta-se também como a crescente participação dos países subdesenvolvidos em fóruns de debate sobre esse tema vem contribuindo, nos últimos anos, para a convergência dos diferentes enfoques em uma postura de consenso, agregando-se outras questões, como sociais, políticas e culturais, que representam prioridades aos países que anteriormente não viam nessas discussões o reflexo de sua realidade. A abrangência das questões envolvidas ao se considerar diferentes interesses, no entanto, dificulta a ação, exigindo que se definam seus conceitos, diretrizes e metas para implementação de métodos de análise da sustentabilidade mais balanceados.

Assim, faz-se um levantamento desses métodos até o ano de 2005, através do estudo de autores que fazem uma avaliação metodológica, considerando diferentes aspectos, tais como as dimensões apreciadas por cada método, quais as variáveis abordadas, qual o seu peso dentro de cada método e os limites para uma aplicação em várias dimensões. Como nenhum dos métodos levantados atende as exigências de uma análise pluridimensional balanceada, procurou-se definir os principais objetivos e metas a serem alcançados por um novo método, e escolheu-se a análise do ciclo de vida como método base para revisão e proposição de uma análise pluridimensional.

\section{1 - O conceito de sustentabilidade.}

Para que se possa fazer uma caracterização de todo o ciclo de vida de um produto é necessário que se tenha claro para qual fim se está coletando os dados, pois para cada tipo de análise são necessários diferentes tipos de dados, e uma coleta de todas as variáveis envolvidas na realidade pode se tornar inviável pelo tempo e recursos financeiros destinados a pesquisa. Assim, colocase como fundamental delimitar sobre quais conceitos da sustentabilidade a análise se pautará, 
deixando claro com quais diretrizes, metas e principalmente embasado em qual visão de sustentabilidade se trabalhará. E para que sejam estabelecidas essas definições, serão resgatados brevemente o histórico do conceito desse termo, sua evolução e contradições usualmente debatidas.

O conceito de sustentabilidade, desde o início ligado à idéia de manutenção de "algo" que perdura ao longo do tempo, era usualmente embasado em princípios ambientais de manutenção dos recursos naturais ou biodiversidade do planeta Terra, como afirma Silva, S. (2000), "As primeiras noções que geraram a utilização de termos baseados em um estado 'sustentável' estavam relacionadas mais diretamente com as questões ecológicas, envolvendo os impactos antrópicos aos ecossistemas naturais". Segundo a mesma autora, alguns marcos representativos para o início desse debate foram a publicação de "Silent Spring", de Rachel Carson em 1962, e do relatório "The limits to growth" em 1972, redigido por um grupo de estudiosos conhecidos como "Clube de Roma". Essas publicações colocam pela primeira vez a capacidade de limite dos ecossistemas do planeta terra, a necessidade de manutenção da biodiversidade e a importância de se mudar a forma como o homem vem atuando sobre ele.

$\mathrm{Na}$ década de 70 o conceito de sustentabilidade começa a se formar ${ }^{1}$ e o mundo volta suas atenções para questões que então se tornariam de importância vital não só para pesquisadores, mas para todos os habitantes do planeta. Um dos primeiros efeitos que atingiu diretamente toda a população terrestre foi a crise gerada pela escassez de combustíveis fósseis, a chamada "crise do petróleo", na década de 70. Segundo Sachs (1993) as atenções ainda se voltaram para a questão ambiental na década de 70 e 80 também pela ampliação dos conceitos empíricos sobre o funcionamento da biosfera e sobre os riscos possíveis de acidentes nucleares e químicos (Three Mile Island, Techrnobyl e Bhopal), de desastres provocados pelo homem (encolhimento do Mar de Aral e destruição ambiental no leste europeu), de aquecimento global da atmosfera e do efeito estufa, além de ameaças à segurança representadas pelos conflitos e disputas por recursos naturais e pela guerra ecológica.

Assim, no bojo do crescente número de congressos internacionais para o debate do futuro do planeta, surgem os conceitos mais divulgados no meio acadêmico sobre o desenvolvimento sustentável, sendo o principal deles o publicado pelo relatório Brundtland em 1987: "Desenvolvimento sustentável é aquele que satisfaz as necessidades do presente sem comprometer a capacidade das gerações futuras de satisfazer as suas próprias necessidades"

\footnotetext{
${ }^{1}$ Em 1974 foi elaborado o conceito de ecodesenvolvimento na conferência das Nações Unidas sobre Comércio e Desenvolvimento, realizada no México, apontado como sinônimo de desenvolvimento sustentável por Sachs (1993).
} 
(WCED, 1987 apud CIB, 1999). Porém, esse novo termo, apesar de inicialmente ter sido considerado consensual, é tido como contraditório por muitos críticos que apontam o paradoxo existente na expressão "desenvolvimento sustentável”, enquanto outros apontam ainda para a existência de uma tensão permanente entre esses dois termos. Há também aqueles que defendem a idéia de que o termo desenvolvimento não devesse vir acompanhado de qualquer adjetivo, considerando a sustentabilidade uma condição necessária para a existência do desenvolvimento, apesar da realidade objetiva estar distante dessa condição (SILVA, S., 2000).

Layrargues (1997) critica diretamente o documento elaborado pela Comissão Brundtland dizendo que:

[...] retira o componente ideológico da questão ambiental, que passa a ser considerada com uma certa dose de ingenuidade e descompromisso, frente à falta de visibilidade do procedimento histórico que gerou a crise ambiental.

Essa visão crítica sobre o foco dado por alguns autores à questão ambiental gera algumas linhas de pensamento que vão para além da questão ecológica. Na década de 80, Sachs traz uma importante contribuição para o debate do desenvolvimento sustentável, e resgata o termo "ecodesenvolvimento", que coloca a questão da "implementação de estratégias ambientalmente viáveis para promover um desenvolvimento socioeconômico eqüitativo" (SACHS, 1993). O autor ainda coloca que esse conceito foi utilizado em seu trabalho na década de 80 como sinônimo do que depois os pesquisadores viriam a chamar de desenvolvimento sustentável. Esse resgate de Sachs do conceito criado na Conferência das nações Unidas sobre Comércio e Desenvolvimento, realizada no México em 1974, traz um grande avanço dentro do conceito de desenvolvimento sustentável, pois inclui as questões "sócioeconômicas", apesar de ainda estar ligada à idéia de que seriam as "estratégias ambientalmente viáveis" que trariam a solução para o desenvolvimento social e econômico, reforçada pela utilização do termo "eco".

Assim como o termo desenvolvimento sustentável, o conceito de sustentabilidade foi alvo de uma grande amplitude de enfoques e divergências teóricas seguindo durante muitos anos como um termo não consensual e que por muito tempo ainda teve seu conceito ligado à idéia de "um estágio que o desenvolvimento sustentável deveria alcançar" (CIB e UNEP-IETC, 2002, P.06).

Seguindo a linha conceitual de desenvolvimento sustentável publicada pelo relatório Brundtland, a Agenda 21, já na década de 90, coloca que uma boa definição para construção sustentável é a elaborada por Kibert na primeira Conferência Internacional para Construções Sustentáveis em Tampa, 1994: “[...] a criação e gerenciamento responsável de um ambiente saudável construído 
em fontes eficientes e em princípios ecológicos” (CIB, 1999). Essa definição já coloca o debate dos "ambientes saudáveis", incluindo questões sociais de qualidade de vida, junto com a preocupação ecológica. Mas a agenda 21 ainda é elaborada colocando as questões ambientais como foco das discussões, sem deixar claras as relações de cada área sobre a outra.

Já Sachs (1986), na década de 80, partindo do resgate do conceito de ecodesenvolvimento, amplia a visão estritamente ambientalista da sustentabilidade, como a colocada por Kibert, e introduz um conceito que se baseia em um tripé, constituído de: "eficiência econômica, justiça social e prudência ecológica” (SACHS, 1986). A inclusão de novas dimensões da sustentabilidade em seu conceito irá partir de críticas, como as do próprio Sachs, que consideram ingênua a crença de que a tecnologia e as novas técnicas ecológicas, apartadas de ações políticas, sociais, econômicas e culturais, pudessem solucionar os problemas colocados pelos próprios ambientalistas.

Essa nova linha conceitual, que não deixa mais as questões sociais e econômicas em segundo plano, é desenvolvida principalmente nas agendas dos países em desenvolvimento, que vêem nesse conceito o reflexo muito mais próximo de sua realidade, com problemas sociais, políticos e econômicos tão latentes quanto os ambientais. Assim, o desenvolvimento sustentável é definido pela Agenda 21 de Construção Sustentável para Países em Desenvolvimento como:

O tipo de desenvolvimento que precisamos ter para alcançar a sustentabilidade. É um processo contínuo de manutenção de um equilíbrio dinâmico entre as necessidades e demandas das pessoas por eqüidade, prosperidade e qualidade de vida, e o que é ecologicamente possível (CIB e UNEP-IETC, 2002, P.06).

Para Silva, S. (2000) a noção de desenvolvimento sustentável está, assim como a sustentabilidade, ligada à idéia de um processo ou tendência norteadora de reflexões e ações determinadas por opções humanas em face ao relacionamento com o meio envoltório em circunstâncias específicas. E justamente pelo seu caráter de "processo norteador", e por estar "relacionado a circunstâncias específicas", não seria possível existir um único caminho para se atingir o desenvolvimento sustentável, como uma fórmula aplicável universalmente.

Assim como Silva, S., Yuba (2005) não delimita o termo sustentabilidade em conceitos estáticos e imutáveis, colocando ao invés disso como algo que está ligado à noção de equilíbrio dinâmico, onde alguns mecanismos ensaiariam diferentes meios e modos até estacionarem em um campo onde não entrariam mais em conflito com valores críticos do ambiente, resultando em diferentes possibilidades de estados sustentáveis. A definição para sustentabilidade dada pela agenda 21 de construção sustentável para países em desenvolvimento vai de encontro às visões de Yuba (2005) 
e Silva, S. (2000), considerando não só o caráter dinâmico da sustentabilidade, mas também incluindo questões sociais, econômicas e culturais, além da ambiental.

[...] a condição ou estado que permitiria a existência do homo sapiens, provido de segurança, saúde e vida produtiva para todas as gerações em harmonia com a natureza e com os valores culturais e espirituais locais (CIB e UNEP-IETC, 2002, P.06).

Apesar do amplo debate acerca do tema da sustentabilidade que vem ocorrendo nas últimas décadas, pode-se notar, através de alguns conceitos apresentados aqui, que existiram pelo menos dois posicionamentos bem distintos em torno do tema, defendidos pelos países desenvolvidos e pelos subdesenvolvidos, ou denominados pela Agenda 21 respectivamente como países do norte e do sul, em documento publicado após o encontro da ONU em 1992.

No item 1.2 explorar-se-á esses diferentes enfoques, optando por um posicionamento frente às divergências desse tema.

\section{2 - As divergências sobre o tema.}

Devido à sustentabilidade ser um conceito muito amplo e holístico, é natural que haja muitos enfoques sobre o mesmo tema, e considerando que uma das questões centrais, o da capacidade de suporte do meio, faz imperativo os diferentes focos de abordagens do tema em cada região. Porém, é possível encontrar não só diferentes abordagens dentro desse conceito, como também conceitos diferentes para o termo sustentabilidade - de acordo com o contexto em que cada autor se encontra ou mesmo pela rápida evolução dos conceitos ligados a esse termo nas últimas décadas - por isso é necessário entender os posicionamentos de alguns segmentos que discutem essa questão na atualidade. A maior cisão acerca do tema foi entre os ditos países do norte e sul nas décadas de 70 e 80 , sendo os primeiros um conjunto de países desenvolvidos e os outros considerados pobres ou em desenvolvimento. Sachs (1993) coloca a disparidade entre esses dois conjuntos:

[...] o abismo entre o Norte e o resto do mundo se evidencia no fato de que os países da Organização para a Cooperação Econômica e Desenvolvimento, com $16 \%$ da população do mundo e $24 \%$ da área terrestre, concentrem $72 \%$ do produto bruto mundial, $73 \%$ do comércio internacional, $78 \%$ de todos os automóveis e $50 \%$ do consumo de energia. Ao mesmo tempo, respondem por 
$45 \%$ das emissões de dióxido de carbono, $40 \%$ das de óxido de sulfúrico, $50 \%$ das de óxido de nitrogênio e $60 \%$ da emissão de resíduos industriais [...] [...] enquanto os países de renda média têm perdas decorrentes das atividades de deterioração comercias de US\$219 bilhões [...] [...] o consumo per capita do norte é de três a oito vezes maior que no sul, para produtos básicos, e 20 ou mais vezes maior para itens como produtos químicos ou automóveis.

Assim, o autor coloca que é "natural" que o norte e o sul tenham perspectivas diferentes, sendo o norte mais preocupado com os riscos ambientais, enquanto o sul tentará resolver suas questões sociais e econômicas, posicionamento também defendido por CIB (1999), que coloca que além dos países terem diferentes diretrizes para a sustentabilidade são poucos os países do norte que irão considerar as questões sociais e econômicas como os principais pontos a serem abordados em estudos de sustentabilidade.

Para Silva, V. (2003) essa disparidade de posicionamentos ocorre porque o desenvolvimento econômico foi encorajado e acelerado, e nos países industrializados a sociedade encontrou um nível de qualidade de vida, de igualdade social e de distribuição de riqueza - ou ao menos de eliminação de extremos de desigualdade - sem precedentes ou paralelo em países em desenvolvimento.

O preço deste desenvolvimento foi a causa ou a acentuação de fenômenos destruição de elementos naturais em seu próprio território ou - como mais tarde seria constatado - em escala global. Por esta razão, a agenda dos países desenvolvidos em relação à sustentabilidade tem sido tão centrada na dimensão ambiental. Uma segunda diferença de contexto notável é o reconhecimento do direito do "outro" - seja ele um vizinho, um operário ou um bairro - existentes nos países desenvolvidos. O resultado prático é o altíssimo nível de regulamentações e de democratização da tomada de decisões orientadas à produção, manutenção e renovação do ambiente construído urbano (SILVA, V., 2003).

Como conseqüência desse posicionamento esses países adotam medidas ditas sustentáveis que visam a recuperação ambiental de áreas degradadas, políticas de uso racional de energia e água, desenvolvimento de técnicas construtivas ambientalmente menos impactantes, entre outras que visam principalmente a manutenção dos ecossistemas.

Essa visão de sustentabilidade colocada pelos países do norte é duramente criticada por alguns autores, que defendem principalmente a não adoção indiscriminada de tal visão para os países do 
sul, pois os atuais problemas ambientais enfrentados por esses países são decorrência de padrões sociais de alto consumo, geração de resíduos e lixo. A adoção de uma postura que ataca as conseqüências (ambientais) dos problemas seria um erro para os países do sul, que poderiam procurar resolver suas causas (padrões sociais, econômicos e políticos). Sobre tal postura Leroy et al (2002) diz:

[...] os padrões de produção e consumo dos países ditos "do norte" é que são apontados como os ideais desejáveis para toda vida humana na terra. Não somos todos iguais, [...] Não temos a mesma base material. [...] Somos pois potencialmente diferenciados nas nossas necessidades, sonhos e desejos. Tudo isso entretanto é negado pelos interessados em nos manterem iludidos.

Outra citação que coloca a incapacidade desse ponto de vista desenvolvimentista ser implantado nos países do sul é a de Sachs (1993):

[...] para proporcionar a todos do terceiro mundo o mesmo padrão de vida material que a rica minoria a que pertencemos, deve-se extrair uma quantidade dez vezes maior de que a atual de combustível fóssil e ampliar a extração de riquezas minerais em cerca de duzentas vezes. Isso é impossível: o único caminho é retroceder.

O autor então aponta a redistribuição da riqueza como uma possível solução, e deixa claro que para se alcançar a sustentabilidade não se deve abordar a questão tecnológica e ambiental, e sim a "divisão de poder" para que se possa distribuir a riqueza de forma mais igualitária; mas assume essa possibilidade como remota, considerando o jogo de interesses dos países desenvolvidos.

O diferente posicionamento desses blocos de países frente ao tema discutido tem como conseqüência uma vasta gama de argumentos e conceitos elaborados para defender o que seria considerada a verdadeira sustentabilidade, que implicitamente conteria os interesses de cada país. Como coloca Chauí (1982), muitas vezes as teorias e conceitos têm a intenção de:

[...] transmitir a idéia de ser uma ideologia autônoma, porém ela seria um conjunto de idéias da classe dominante de uma época e tal autonomia é produzida no momento em que se faz uma separação entre os indivíduos que dominam e as idéias que dominam, de tal modo que a dominação de homens sobre homens não seja percebida porque aparece como dominação das idéias sobre os homens. 
Assim, muitos autores colocaram críticas de forma contundentes às proposições que começavam a ser elaboradas nas décadas de 70 e 80 , resultando em um não consenso sobre seu conceito e posicionamentos frente ao tema da sustentabilidade, não só por parte dos pesquisadores mas de diversos atores sociais, como coloca Bakens (2003),

\begin{abstract}
Tomadores de decisão, profissionais e pesquisadores [...] frequentemente parecem falar línguas diferentes, baseados em diferentes entendimentos do que a sustentabilidade da construção civil engloba, distintas bagagens culturais e educacionais, assim como distintas responsabilidades e interesses - juntamente com distintas definições de questões, prioridades e possíveis soluções.
\end{abstract}

Sachs aponta como um caminho o processo participativo de todos os agentes envolvidos, garantindo a eles igual poder de decisão; assim, os diferentes interesses iriam se confrontar, gerando a necessidade de se delimitar as metas, diretrizes e planos para uma solução mais equilibrada para cada caso, visto o caráter holístico em que a sustentabilidade está embasada.

É clara a importância de não haver processos de modernização de cima para baixo, pois essa não participação da população (dimensão política da sustentabilidade) tem produzido freqüentemente graves desequilíbrios socioambientais, como no caso de Papua-Nova Guiné, enquanto os sistemas de gestão de recursos e meio ambiente baseados na comunidade provam a sua eficiência e merecem ser protegidos e fortalecidos. (SACHS, 1993).

Esse processo de diálogo pode trazer não só diretrizes mais equilibradas para atores como governo e comunidade, mas também entre países desenvolvidos e subdesenvolvidos. A Cúpula Mundial sobre Desenvolvimento Sustentável, que ocorreu em 2002 em Johannesburgo na África do Sul, já levantou uma série de questões, sempre consideradas díspares entre norte e sul, que foram tratadas dessa vez como um só problema mundial, e não mais como problemas de países isolados. Algumas questões debatidas foram: o peso que os países do norte têm sobre a economia dos mais pobres, apontando como solução o alívio das dívidas externas, a evolução para o comércio justo no lugar do comércio livre, a redução da "pegada ecológica" dos países do norte, a garantia dos direitos de subsistência do sul, assumindo o compromisso de em vez de prosseguir com uma política desenvolvimentista, adotar um padrão de consumo diferente do atual padrão dos países desenvolvidos, entre outros. (SACHS, W., 2002). No "Memorando para cúpula Mundial do Desenvolvimento Sultentável” é colocada com destaque que:

Os tempos de desenvolvimento por imitação terminaram. Não porque a emulação do Norte não tenha produzido os efeitos desejados, mas porque o 
modelo de desenvolvimento do Norte é obsoleto, está historicamente ultrapassado. Até a eclosão da crise ambiental, ainda era possível atribuir um certo grau de superioridade à civilização tecnológica, que emergiu em ambos os lados do Atlântico no último quarto do século XX. Tornou-se óbvio, porém, que suas realizações gloriosas são na verdade ilusões de ótica disfarçadas.

Apesar de nos dias atuais o debate da sustentabilidade começar a apontar para um consenso, o da necessidade de se introduzir o tema de forma ampla e multidisciplinar para além da questão ambiental, como coloca Diegues (1992): “é imperioso que cada sociedade se estruture em termos de sustentabilidades próprias, segundo suas tradições culturais, seus parâmetros próprios e sua composição étnica específica", ainda se tem uma longa discussão sobre como abordar essas questões pluridimensionais, como poderá se verificar no próximo item.

\section{3 - As dimensões da sustentabilidade e suas diretrizes.}

Partindo-se do consenso de uma forma de se abordar o tema da sustentabilidade para além da idéia de remediação dos impactos antrópicos sobre o ecossistema, diversos autores a partir das décadas de 80 e 90 procuraram explorar novas bases para uma ação efetiva no campo da sustentabilidade, como coloca Paula et al (1997, p.204):

[...] é central na perspectiva crítica a idéia de que a crise ambiental é um produto histórico das formas concretas de produção, reprodução material, das formas concretas de apropriação da natureza, formação dos territórios, do exercício do poder e organização social, dos modos, mentalidades e culturas.

A autora procura definir assim as causas do desequilíbrio no ecossistema, ficando claro que os principais pontos a serem discutidos estão na ordem social, cultural e política; e não mais exclusivamente nas dimensões ambientais e econômicas, como era colocado pelos autores da década de 70. Sachs (1993) diz que com a abertura do foco da sustentabilidade houve um crescimento do componente humano no lugar do econômico e ambiental, dado pela noção de desenvolvimento humano, a mesma que deu origem ao IDH, elaborado com intuito de oferecer um panorama baseado nas relações sociais em vez da econômica. E através dessa perspectiva, elabora o conceito das dimensões que a sustentabilidade deveria abranger.

- sustentabilidade social: uma civilização com maior grau de equidade na distribuição de renda e bens, reduzindo o distanciamento e as discrepâncias entre as camadas sociais; 
- sustentabilidade econômica: é a eficiência econômica medida em meios macrossociais e não através de critérios microeconômicos de rentabilidade empresarial;

- sustentabilidade ecológica: racionalização dos recursos esgotáveis ou danosos ao meio ambiente com a redução do volume de resíduos por meio da conservação de energia e práticas de reciclagem, pesquisas em tecnologias ambientalmente mais adequadas e implementação de políticas de proteção ambiental;

- sustentabilidade geográfica ou espacial: configuração rural-urbana mais equilibrada, com a redução de concentrações urbanas e das atividades econômicas com a proteção de ecossistemas frágeis, práticas de agricultura regenerativa;

- sustentabilidade cultural: práticas que contemplem a importância das raízes endógenas e especificidades locais do ecossistema, de forma que as transformações estejam em sintonia com um contexto que permita a continuidade cultural.

Essa multiplicidade de abordagens e amplitude do tema permite uma flexibilidade de tratamento, podendo-se inclusive incorporar novas dimensões que sejam exigidas pelo problema em questão (SILVA, S. 2000). Assim, o próprio Sachs colocaria posteriormente um dos fatores considerado por vários autores essencial para se atingir uma maior sustentabilidade: a participação de todos os agentes nos processos decisórios, dizendo que "a emergência da sociedade civil na cena política como um terceiro sistema de poder, ao lado dos Estados e do poder econômico, deve ser vista como um dos acontecimentos mais importantes dos últimos 25 anos" (SACHS, 1993). O autor ainda cita bons exemplos de organizações de pessoas em movimentos populares de base que lutaram pela sobrevivência, acesso à alimentação, moradia e meio ambiente; colocando a democracia participativa em todos os níveis como um objetivo a ser alcançado.

Outros autores também ressaltam a importância dessa nova dimensão a ser abordada e como a sustentabilidade só conseguirá efetivamente se estabelecer com uma nova forma de organização da sociedade. Para Santos, M. (1994), o projeto de desenvolvimento sustentável é, sobretudo, um desafio político por demandar a identificação dos sujeitos cuja razão social seria a constituição do referido projeto, e afirma que a sustentabilidade requer mais interesse social e político do que resoluções técnicas ou financeiras, para que se possa instruir uma outra relação entre sociedade e natureza. A própria agenda 21 de construção sustentável para países em desenvolvimento coloca a necessidade de se mudar a forma como estão estabelecidas as relações de poder entre os países, para que então algumas mudanças na economia mundial possam se consolidar nos modelos de 
desenvolvimento, nas práticas de produção e nas atitudes em relação aos recursos e aos modos de vida (CIB E UNEP-IETC, 2002).

A inclusão, ou exclusão, de novas dimensões não é somente possível como desejável, segundo alguns autores, como Silva, S. (2000) que defendem que a sustentabilidade ainda deve estar relacionada com o contexto de cada local, considerando-o um caráter indissociável da sustentabilidade.

Partindo-se do pressuposto de que a sustentabilidade não é algo que se adquira de forma completa, definitiva e permanente e não pode se revelar por meio de postulados científicos, o universo fica estabelecido em princípios e diretrizes que contemplem ações e intervenções específicas e limitadas temporal e espacialmente. Assim podemos dizer que cada região, em determinada época, possuirá políticas e diretrizes específicas para atingir o que consideram um estado de maior sustentabilidade, podendo em muitos casos ser contraditória as diretrizes colocadas por outros agentes em contextos diferentes (SILVA, S., 2000).

Assim, alguns autores como Silva, S. (2000) e Yuba (2005) procuraram, através de uma ampla revisão bibliográfica, sistematizar os princípios, estratégias e características da sustentabilidade mais recorrentes dentro dos principais autores que abordam a pluridimensionalidade do tema. Como resultado as autoras citadas chegaram à sistematização desses itens, que podem ser vistos no quadro 1 (dos princípios e estratégias) e no quadro 2 (das características da sustentabilidade). Procurou-se acrescentar dentro dos princípios da dimensão social a visão de Sachs (1993) e CIB E UNEP-IETC (2002) sobre a necessidade de abordar o tema da melhoria da qualidade de vida da população do terceiro mundo, tema já discutido nesse capítulo, e amplamente abordado pelos autores citados e outros. 
Quadro 1: Princípios e estratégias da sustentabilidade

\section{Princípios e Estratégias da Sustentabilidade}

\begin{tabular}{|c|l|}
\hline $1^{\text {a }}$ dimensão & $\begin{array}{l}\text { Manutenção da integridade ecológica por meio da preservação das várias formas de } \\
\text { poluição, da prudência na utilização dos recursos naturais, na preservação da diversidade } \\
\text { da vida e do respeito à capacidade de carga dos ecossistemas. }\end{array}$ \\
\hline $\begin{array}{c}2^{a} \text { dimensão } \\
\text { Social }\end{array}$ & $\begin{array}{l}\text { Viabilização de uma maior equidade de riquezas e de oportunidades, e aumento da } \\
\text { qualidade de vida da população dos países subdesenvolvidos, combatendo-se as práticas } \\
\text { de exclusão, discriminação e reprodução da pobreza e respeitando-se a diversidade em } \\
\text { todas as formas de expressão. }\end{array}$ \\
\hline $\begin{array}{c}3^{a} \text { dimensão } \\
\text { Econômica }\end{array}$ & $\begin{array}{l}\text { Realização do potencial econômico que contemple prioritariamente a distribuição de } \\
\text { riqueza e renda associada a uma redução das externalidades socioambientais, buscando- } \\
\text { se resultados macrossociais positivos. }\end{array}$ \\
\hline $\begin{array}{c}4^{\text {a }} \text { dimensão } \\
\text { Política }\end{array}$ & $\begin{array}{l}\text { Criação de mecanismos que incrementem a participação da sociedade nas tomadas de } \\
\text { decisões, reconhecendo e respeitando os direitos de todos, superando as práticas e } \\
\text { políticas de exclusão e permitindo o desenvolvimento da cidadania ativa. }\end{array}$ \\
\hline $\begin{array}{c}5^{\text {a }} \text { dimensão } \\
\text { Cultural }\end{array}$ & $\begin{array}{l}\text { Garantia de preservação de patrimônios históricos, urbanísticos, paisagísticos e } \\
\text { ambientais, respeitando a diversidade das culturas dos povos em suas formas expressão } \\
\text { e representação. }\end{array}$ \\
\hline
\end{tabular}

Fonte: Adaptado de SILVA, S. (2000).

Quadro 2: Síntese das características básicas da sustentabilidade

\section{Caráter progressivo}

- Caráter de tendência: a sustentabilidade se apresenta como uma condição a ser introjetada em um processo onde se pretenda atingir determinadas metas devendo ser continuamente construída e permanentemente reavaliada;

- Caráter dinâmico: não se trata de algo tangível que se adquira definitiva e completamente, mas uma condição que deve interagir com o dinamismo da realidade em que se insere, adequandose a fatores conjunturais, estruturais ou imprevisíveis;

\section{Caráter holístico}

- Caráter plural: a sustentabilidade é pluridimensional e envolve aspectos básicos tais como: ambientais, econômicos, sociais, políticos e culturais. Novas dimensões podem ser acrescentadas se o problema em questão assim o exigir;

- Caráter de indissociabilidade: além do caráter plural que pressupõe o envolvimento de vários aspectos, existe um vínculo indissociável entre eles exigindo a sua plena consideração para que se garanta uma condição sustentável;

- Caráter interdisciplinar: devido à amplitude de interações que são contempladas em suas considerações, demanda a confluência de diferentes áreas do conhecimento, tanto pra a construção de suas compreensões teóricas como de suas ações práticas;

\section{Caráter histórico}

- Caráter espacial: embora a noção de sustentabilidade tenha um forte perfil de origem que valoriza as condições endógenas, ela não pode prescindir da inserção e interação dos contextos locais com os mais amplos, contemplando também as causas e conseqüências das pegadas ecológicas;

- Caráter temporal: a relação de tempo adquire uma importância fundamental no equacionamento das ações praticadas no passado, no presente e as que serão exercidas no futuro. Quando se trata do meio ambiente construído urbano, geralmente se adota o tempo social do universo antrópico;

- Caráter participativo: a preservação de uma condição sustentável tem uma forte interdependência com $\mathrm{o}$ aspecto da diversidade participativa dos agentes sociais, na medida em que a presença ou não deste fator pode tanto contribuir, como comprometer as metas pretendidas. 
Partir-se-á então, nesse trabalho, das características básicas, princípios e estratégias da sustentabilidade para se fazer a análise sobre os avanços ou retrocessos das experiências que vêm sendo realizadas atualmente ou, como irá ser tratado adiante, da forma como essas experiências vêm sendo avaliadas pelos métodos de análise da sustentabilidade atualmente utilizados.

\subsection{Panorama dos métodos de análise da sustentabilidade e critérios para uma análise mais balanceada}

A vasta gama de posicionamentos frente ao tema da sustentabilidade gerou não só dificuldades para a definição de um conceito universal, como também uma infinidade de maneiras de se posicionar frente às experiências concretizadas e às formas de se avaliar essas experiências. Surgem então, ao longo das últimas décadas, dezenas de métodos que se propõem a analisar o "nível de sustentabilidade" dos empreendimentos e edificações. Hoje já existem trabalhos que procuram comparar os métodos de análise de sustentabilidade, buscando analisar quais seriam os melhores dentre os existentes, ressaltando suas lacunas e potencialidades.

Silva, V.(2003) faz em seu trabalho o levantamento de alguns métodos existentes e procura classificá-los em dois grandes grupos: os criteria-based, que têm suas estruturas organizadas em função de inputs ou campos em que investidores, projetistas e construtores precisam necessariamente tomar decisões tais como implantação, uso da água e energia, materiais e ambiente interno; e os sistemas LCA-based (Life-Cycle-Assessment) que são organizados pelos impactos ambientais associados a elementos ou características do edifício. Tukker (2000 apud Silva, P., 2003, p. 31) define o Life-Cycle-Assessment como:

[...] uma metodologia de avaliação de impactos ambientais associados a produtos, processos ou atividades. Isto, através da identificação, da quantificação e da avaliação de todos as matérias primas e energia consumidas a rejeitos gerados ao longo do ciclo de vida, ou seja, desde a extração da matérias primas até a disposição final dos resíduos.

A autora fez uma sistematização das variáveis levantadas por cada método, avaliando qual a sua importância dentro da análise, além de compará-las entre os diferentes métodos. O resultado desse levantamento pode ser visto no gráfico da figura 1. 


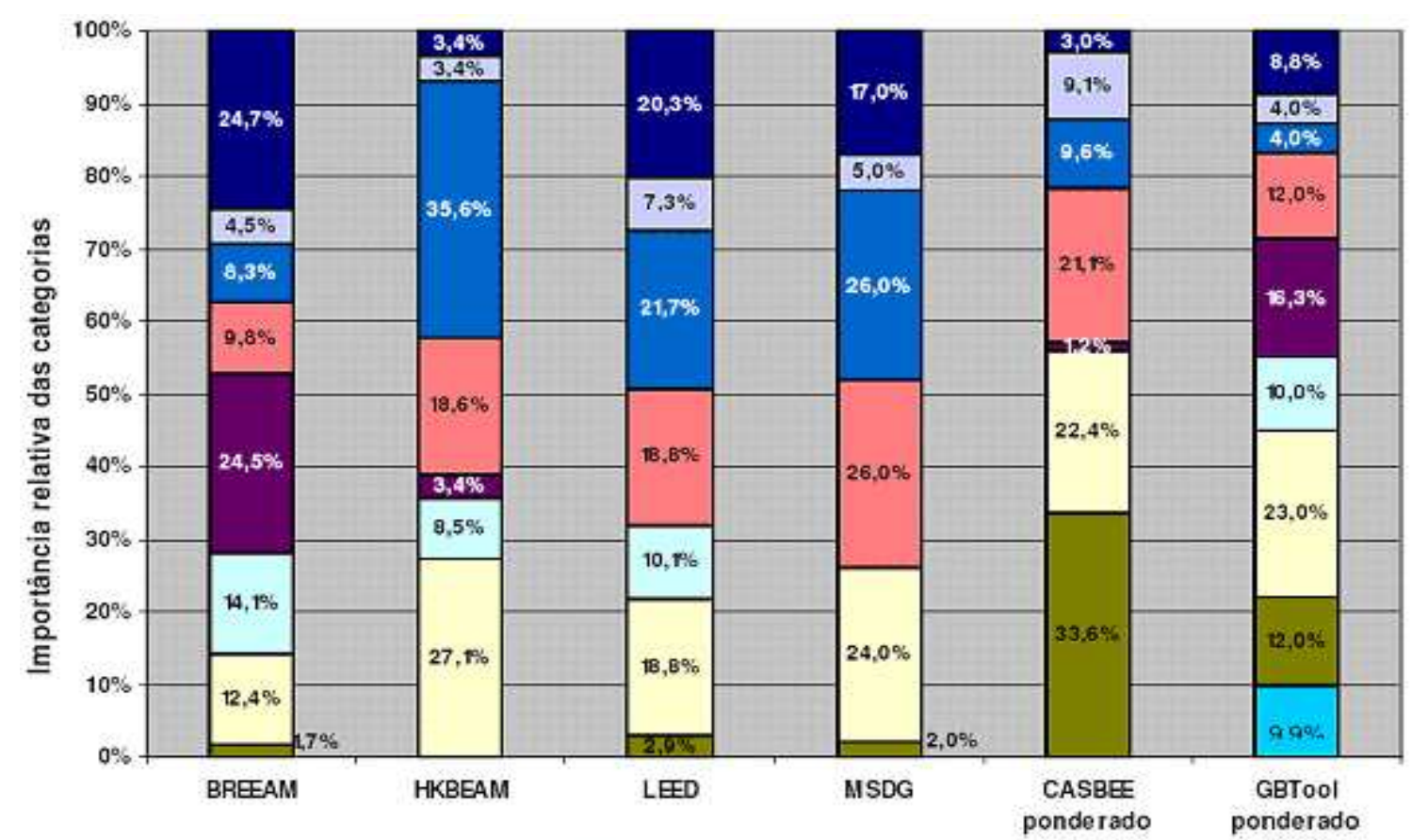

- Estratégias de imlantação •Prevenção de poluição

口Gestão do uso da água $\quad$ a Gestão ambiental do processo

- Gestão do uso da energia aGestão da qualidade do ambiente interno

- Gestão de materiais e aQualidade dos serviços

(redução de) residuos

ם Desempenho econômico

Figura 1: Distribuição dos créditos ambientais do BREEAM, HKBEAM, LEEDTM, MSDG, CASBEE e GBTool após a normalização.

Fonte: Adaptado de SILVA, V. (2003).

O gráfico mostra a grande quantidade de variáveis relacionadas aos impactos no ecossistema, enquanto somente o desempenho econômico e a qualidade dos serviços são colocados como itens a serem avaliados fora da dimensão ambiental. No método HKBEAM nenhuma dessas variáveis é considerada, no LEED, MSDG e BREEAM considera-se somente a qualidade de serviços e com o peso máximo de $2,6 \%$, e no método CASBEE somente uma das variáveis é adicionada. O GBTool inclui as duas variáveis, mas que somadas não chegam a $25 \%$ do peso total, o que mostra o baixo peso dado para questões que não são ambientais. A idéia de maiores ou menores pesos ou a idéia de prioridade dentro das dimensões de sustentabilidade, assim como o foco ou a ênfase, são questionáveis devido à inter-relação dessas questões, que segundo YUBA (2005) "[...] podem ser de causa e conseqüência, contradições e conflitos, que resultam na determinação de ganhos e perdas de sustentabilidade". 
A autora também faz um levantamento dos métodos de análise existentes e consegue abranger um grande número deles, analisando suas qualidades e deficiências. Foram levantados 28 métodos e classificados em unidimensionais, bidimensionais e pluridimensionais. A quantidade de métodos levantados e as dimensões abordadas por eles estão descritos no quadro 3.

Quadro 3: Métodos de análise da sustentabilidade.

\begin{tabular}{|c|c|c|}
\hline Nome do método e ano & Dimensão abordada & País \\
\hline Método das preferências ambientais (1996) & Ambiental & Holanda \\
\hline Enviromental Building News (EBN) (1995) & Ambiental & EUA \\
\hline $\begin{array}{l}\text { Declarações Ambientais elaborada pelo Trätek (Swedish } \\
\text { Institute for Wood Technology Research) (1996) }\end{array}$ & Ambiental & Suécia \\
\hline ECOPROFILE (1999) & Ambiental & Noruega \\
\hline Environmental Status (Miljöstatus) (2002) - $4^{a}$ versão & Ambiental & Suécia \\
\hline Pegada Ecológica (PE) (1997) & Ambiental & \\
\hline Ecoquantum (2001) & Ambiental & Holanda \\
\hline Lista Bown Milieu Evaluatie - BME (1998) & Ambiental & Holanda \\
\hline Social Impact Assessment - SIA (1994) & Social & \\
\hline Análise do Custo Benefício Social - SCBA & Social & \\
\hline Ecoeffect (2004) & Ambiental e econômica & Suécia \\
\hline $\begin{array}{l}\text { Building for Envarionmental and Economic } \\
\text { Sustainability -BEES } 3.0 \text { (1994) }\end{array}$ & Ambiental e econômica & EUA \\
\hline Green Globes (2004) & Ambiental e social & Canadá \\
\hline Green Building Digest - GBD (1995) & Ambiental e social & Reino Unido \\
\hline $\begin{array}{l}\text { Comprehensive Assessment system for Building } \\
\text { Environmental Efficiency - CASBEE (2002) }\end{array}$ & Ambiental e social & Japão \\
\hline Pimwag (2001) & Ambiental e social & Finlândia \\
\hline Twin Model & Ambiental e social & Holanda \\
\hline ISO & $\begin{array}{l}\text { Ambiental, social e } \\
\text { econômica }\end{array}$ & \\
\hline $\begin{array}{l}\text { Leardeship in Energy and Environmental Designe - } \\
\text { LEED (2002) }\end{array}$ & $\begin{array}{l}\text { Ambiental, social e } \\
\text { econômica }\end{array}$ & EUA \\
\hline EcoProP (2001) & $\begin{array}{l}\text { Ambiental, social e } \\
\text { econômica }\end{array}$ & Finlândia \\
\hline Ecopoints (2001) & $\begin{array}{l}\text { Ambiental, social e } \\
\text { econômica }\end{array}$ & Reino Unido \\
\hline $\begin{array}{l}\text { National Australian Building Enviromental Rating } \\
\text { Systen - NABERS (2001) }\end{array}$ & $\begin{array}{l}\text { Ambiental, social e } \\
\text { econômica }\end{array}$ & Austrália \\
\hline $\begin{array}{l}\text { Network on Construction and City related Susteinability } \\
\text { Indicators - CRISP }\end{array}$ & $\begin{array}{l}\text { Ambiental, social e } \\
\text { econômica }\end{array}$ & \\
\hline Green Building Assessment Tool - GBToll (1998) & $\begin{array}{l}\text { Ambiental, social e } \\
\text { econômica }\end{array}$ & $\begin{array}{l}24 \text { países que } \\
\text { desenvolvem }\end{array}$ \\
\hline $\begin{array}{l}\text { Building Research Establishment Environmental } \\
\text { Assessment Method - BREEAM (1990) }\end{array}$ & $\begin{array}{l}\text { Ambiental, social e } \\
\text { econômica }\end{array}$ & Reino Unido \\
\hline MaSe-System & $\begin{array}{l}\text { Ambiental, social e } \\
\text { econômica }\end{array}$ & Noruega \\
\hline Susteinable Building Assessment Tool - SBAT & $\begin{array}{l}\text { Ambiental, social e } \\
\text { econômica }\end{array}$ & África do Sul \\
\hline Athena & $\begin{array}{l}\text { Ambiental, social e } \\
\text { econômica }\end{array}$ & Canadá \\
\hline
\end{tabular}

Fonte: Adaptado de YUBA (2005) 
Apesar de aparentemente o quadro 3 mostrar uma grande variedade de métodos que adotariam um princípio pluridimensional, poucos estão efetivamente embasados no caráter holístico da sustentabilidade. Mesmo para os métodos que abordam o tema para além da questão ambiental, Silva, V.(2003 p. 6) coloca que se concentram prioritariamente nessa dimensão da sustentabilidade, e Yuba (2005 p. 158) ainda complementa:

Além das fases do ciclo de vida, o conjunto de questões de cada dimensão também é analisado separadamente em todos os métodos. Não foi identificada relação inter nem intradimensões e todas as questões são apresentadas em paralelo, simplificando demasiadamente a complexidade das relações entre as questões de sustentabilidade.

A partir desse contexto é possível entender como os métodos de avaliação de sustentabilidade se desenvolveram de forma tão desequilibrada, focando preponderantemente em apenas uma das dimensões, a ambiental. Portanto, Deakin et al (2002) diz que, para diminuir as deficiências dos métodos atuais ao se avaliar a complexidade do ambiente construído, deve-se buscar um método que integre as áreas ambientais, sociais e econômicas.

Yuba (2005) ainda acrescenta que para uma avaliação ser considerada pluridimensional, esta deve necessariamente fazer uma análise dos elos existentes entre diferentes etapas do processo, bem como a relação de ganhos e perdas entre cada dimensão analisada, para assim gerar ações efetivas para cada contexto específico e para as áreas com maior deficiência.

Outra questão a ser considerada que dificulta as análises atualmente é a forma como o conhecimento é produzido e transferido para a sociedade, não aproximando os especialistas das diferentes áreas, nem os diferentes setores da sociedade para um diálogo construtivo. Segundo Lyle (1994) "as disciplinas acadêmicas são áreas de conhecimento e habilidade estreitamente definidos, com limites protegidos invejosamente, tendo pouco a fazer com a realidade dos processos naturais", e Barkens (2003) e Silva, V. (2002) ainda colocam que a atual tendência não mostra uma cooperação entre os profissionais relacionados com a construção civil para elaboração de um único método que considere o conjunto de questões. Assim, é colocada a necessidade de um método que possa ter uma base de dados para ser comparada com outras experiências de forma normalizada, transparente e sem distorções.

Como solução alguns autores apontam para uma visão mais abrangente dos objetos de estudo, incluindo várias áreas do conhecimento. 
[...] a visão sustentável deve estar munida da análise do maior número possível de interações entre as variáveis de um dado contexto. Por isso, para compreender a sustentabilidade seria necessário entender como a realidade opera. Por sua vez, a compreensão da dinâmica requer uma análise abordando diferentes dimensões, havendo uma escala mínima para lidar com a diversidade de questões, maior do que normalmente utilizada pelas pesquisas tradicionais $[\ldots][\ldots]$ Essa escala seria a da cadeia produtiva (YUBA 2005, pag. 5).

Assim, a elaboração de ferramentas para análise da sustentabilidade foi mais bem sucedida em países onde o governo, investidores, arquitetos e especialistas em ciclo de vida desenvolveram uma linguagem e indicadores comuns, trabalhando em rede ao longo de todo o ciclo de vida (BOONSTRA; PETTERSEN, 2003 apud YUBA, 2005). Outra vantagem dos métodos baseados em análises do ciclo de vida é que, apesar de demandarem um grande trabalho de levantamento do inventário, possibilitam o cálculo de valores absolutos, de entradas e saídas, que representam um grande avanço para a transparência dos dados, além de possibilitar uma base comparativa universal, fundamentado em valores matemáticos (SPERB, 2000).

Observando a obrigatoriedade de uma grande abrangência (ciclo de vida) e pluridimensionalidade (necessidade da atuação de diversas áreas para um entendimento da realidade) para que haja uma boa análise da sustentabilidade, e a partir das críticas e análises dos métodos levantados em seu trabalho, YUBA (2005) faz um resumo dos objetivos de um método que busca uma análise pluridimensional (ver quadro 4) que, para obter um resultado mais plural e inter relacionado das dimensões da sustentabilidade, deveria conter:

- As relações entre dimensões e entre processos da cadeia produtiva

- Como cada questão repercute nas outras questões;

- os ganhos e perdas de sustentabilidade em uma dimensão

- os ganhos e perdas de sustentabilidade entre as dimensões

- Cenários de maior e menor sustentabilidade. 
Quadro 4: Proposição para objetivos das avaliações de sustentabilidade

\begin{tabular}{|c|c|}
\hline Objetivos principais & Objetivos secundários \\
\hline $\begin{array}{l}\text { Compreender a dinâmica } \\
\text { do contexto }\end{array}$ & $\begin{array}{l}\text { Identificar a dinâmica } \\
\text { - dos processos que geram impactos } \\
\text { - das relações entre os elementos (importância das relações, selecionar } \\
\text { indicadores, atribuir pesos, definição de níveis de referência e metas e } \\
\text { equilíbrio entre ideal e possível) }\end{array}$ \\
\hline $\begin{array}{l}\text { Compreender os } \\
\text { elementos da dinâmica do } \\
\text { contexto }\end{array}$ & $\begin{array}{l}\text { Identificar os elementos: } \\
\text { - fatores impactantes } \\
\text { - melhores práticas }\end{array}$ \\
\hline $\begin{array}{l}\text { Comunicar / informar } \\
\text { sobre a situação dos } \\
\text { desempenhos }\end{array}$ & $\begin{array}{l}\text { - quantificar os impactos ou quaisquer outros dados qualitativos } \\
\text { - simplificar ou popularizar os dados } \\
\text { - uniformizar os dados produzidos } \\
\text { - explicitar a situação atual } \\
\text { - monitorar o desenvolvimento do evento analisado } \\
\text { - explicitar a tendência à maior ou menor sustentabilidade } \\
\text { - servir de base para a tomada de decisões }\end{array}$ \\
\hline
\end{tabular}

Fonte: Adaptado de YUBA (2005).

Nesse trabalho serão adotados os objetivos e metas colocados por YUBA (2005) como critérios para escolha dos métodos de análise da sustentabilidade, procurando revisá-los a partir dos pontos aqui levantados e discutidos, visando uma análise mais equilibrada das diferentes dimensões da sustentabilidade.

\subsection{Escolha do método de análise da sustentabilidade.}

A partir das críticas aos métodos atualmente utilizados e dos quadros de objetivos e resultados esperados, nesse trabalho será proposta a utilização do método de análise do ciclo de vida, devido aos seguintes fatores:

- o levantamento de toda a cadeia através de entradas e saídas permite a formulação de uma base de dados nacional, que estimularia o levantamento das condições do contexto brasileiro, repudiando a utilização de um método por imitação (YUBA, 2005);

- o inventário levantado é uma base de dados qualitativa, conseqüentemente mais transparente e confiável, além de uniformizar os dados em bases confiáveis para que haja comparações sem distorções (SPERB, 2000); 
- identifica os impactos ambientais ao longo de toda a cadeia, possibilitando verificar quais os processos causadores de impactos e sua relação com o resto da cadeia produtiva (ABNT, 2001);

- é normalizado internacionalmente pela International Standartization Organization (ISO) e no Brasil pela Associação Brasileira de Normas Técnicas (ABNT), já tendo uma ampla legitimidade no cenário internacional e nacional, facilitando estudos comparativos entre os trabalhos já realizados;

- é o método mais reconhecido e recomendado pelos trabalhos de avaliação dos métodos de análise da sustentabilidade, (YUBA, 2005; SILVA, V., 2003; SPERB, 2000; DEAKIN et al, 2002).

Porém, como já colocado anteriormente, o método de análise do ciclo de vida, assim como todos os outros analisados por Yuba (2005), Sperb (2000), Silva, V (2003), concentram-se na dimensão ambiental, sendo necessário, portanto, uma revisão desse método, procurando ampliá-lo para abranger alguns objetivos e resultados esperados não levantados pelo ACV, tais como:

- as relações entre dimensões e entre processos da cadeia produtiva;

- como cada questão repercute nas outras questões;

- os ganhos e perdas de sustentabilidade em uma dimensão;

- os ganhos e perdas de sustentabilidade entre as dimensões.

Além de observar as diferentes dimensões é necessário verificar a escala de ação de cada método, podendo variar desde o edifício e materiais construtivos, até empresas, estados ou países, sendo que cada uma teria sua contribuição. Silva, V. (2003) esquematiza essas escalas e exemplifica com alguns métodos atuais (figura 2). 


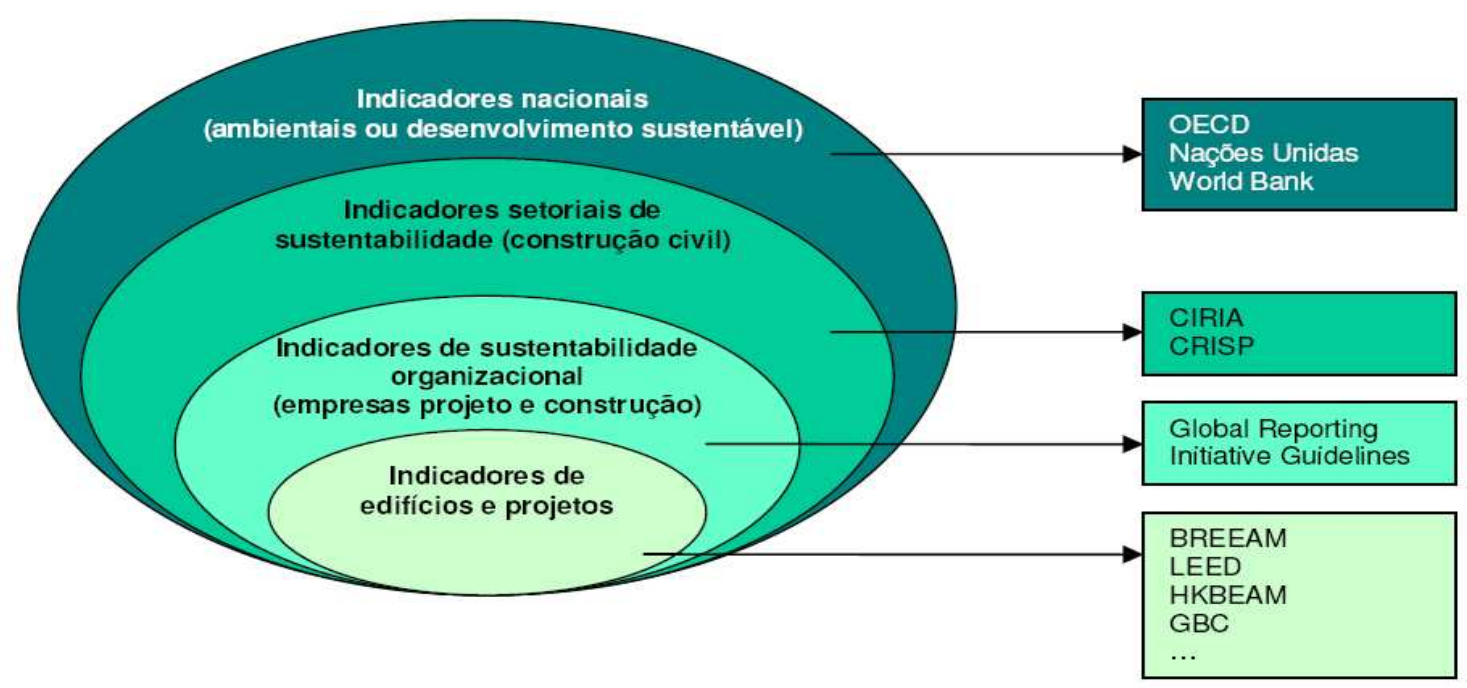

Figura 2: Escalas de ação das principais iniciativas de organização de indicadores ambientais /de desenvolvimento sustentável / de sustentabilidade. Fonte: SILVA, V. (2003).

A atual norma sobre avaliação do ciclo de vida diz que o método é "uma técnica para avaliar aspectos ambientais e impactos associados a um produto" (ABNT, 2001), restringindo-o à avaliação de edifícios ou sistemas construtivos e materiais construtivos, delimitando assim sua escala de ação. Porém Yuba (2005) e ABNT (2001) colocam que o método de análise do ciclo de vida pode trazer benefício não só para a escala do produto ou edifício, mas também:

- para os consumidores: informação para orientar o consumo de produtos e dar oportunidade para o seu envolvimento em estratégias conjuntamente com as empresas e outros interessados, para aumentar a sustentabilidade;

- para as empresas: avaliação ambiental, de saúde e segurança, tecnológica e de gerenciamento, melhoria da imagem da empresa;

- para os governos: benefícios ambientais à sociedade e exemplo de uso e disseminação da responsabilidade global no apoio às iniciativas de implementação de análises de ciclo de vida como ferramenta para definir as prioridades na legislação e auxiliar na determinação de taxas e impostos.

A revisão do método da avaliação de ciclo de vida também buscará ampliar sua escala de ação, saindo do edifício e materiais construtivos para o organizacional, além de buscar integrar as diferentes dimensões e o processo de ganhos e perdas da sustentabilidade ao longo de toda a cadeia. 
Além da ampliação da escala de ação, Silva, V. (2003) ainda indica que é necessário: “[...] saltar da avaliação ambiental para a avaliação da sustentabilidade dos edifícios, e contemplar também os aspectos sociais e econômicos relacionados à produção, operação e modificação do ambiente construído". A autora ainda coloca que essa mudança poderá ser feita através da adição de variáveis das dimensões sociais e econômicas nas entradas e saídas do levantamento de inventários, assunto que será abordado na adaptação do método de avaliação do ciclo de vida para uma análise pluridimensional durante a aplicação desse no objeto de estudo durante o capítulo 3.

Identificado qual é o método mais adequado para o contexto brasileiro, suas potencialidades e limitações, poder-se-á destacar quais as lacunas existentes nos estudos feitos até aqui e, através das perguntas, hipóteses e objetivos de pesquisa, propor uma estrutura de trabalho para a formulação de uma análise que aborde a pluridimensionalidade, o que será feito no capítulo 2. 


\section{Capítulo 2}

\section{Método de pesquisa}

A partir da revisão da literatura sobre os conceitos e métodos da sustentabilidade, constatou-se a diversidade de enfoques dados para esse tema, que podem passar de uma visão estritamente ambientalista e focada em questões de manutenção e equilíbrio dos ecosistemas, até enfoques mais holísticos, que procuram compreender as diferentes variáveis sociais, culturais e políticas e como essas podem interferir no meio ambiente, sendo muitas vezes causadoras desses desequilíbrios. Assim, colocou-se que o estudo das relações dessas diferentes dimensões seria parte essencial de uma análise que procura identificar os ganhos e perdas de sustentabilidade de um determinado objeto, para que então possam ser tomadas decisões para melhorar a forma como vivemos e atuamos no nosso planeta. Também foi constatado que, assim como os conceitos de sustentabilidade, os estudos feitos atualmente avaliam majoritariamente aspectos ambientais, e raramente abordam outras questões relacionadas a esses temas e quando o fazem, só abordam suas dimensões de forma isolada não procurando identificar suas relações. Essas avaliações são decorrentes dos métodos de análise utilizados atualmente, que também procuram focar em uma única dimensão da sustentabilidade ou algumas de forma isolada, não sendo encontrado na literatura nenhum método capaz de explicitar as relações necessárias para uma análise pluridimensional.

Esse debate contrasta com o quadro geral de como construção civil vem atuando atualmente, pois seu setor, que é responsável por grandes impactos, ainda procura soluções de cunho estritamente técnicos ou focados em algumas questões específicas, principalmente a ambiental, como mostrado no texto de apresentação, não contribuindo assim para resolução dos problemas sociais, políticos ou culturais relacionados a seus estudos, que muitas vezes são as causas dos problemas atacados.

Portanto, nesse capítulo serão desenvolvidas, a partir das lacunas encontradas na literatura geral, questões de pesquisa capazes de nortear as hipóteses e objetivos que abordem esses temas. Ainda será feita a decomposição das perguntas, hipóteses e objetivos da pesquisa em principais e secundários, para um melhor entendimento das perguntas que precedem a pergunta principal, permitindo que essa seja respondida, assim como hipóteses e objetivos. Posteriormente, serão apresentados a estratégia geral de pesquisa e seus métodos e etapas, para que esses objetivos 
sejam alcançados, finalizando-se com a apresentação do objeto empírico, que é a cadeia envolvida na produção do sistema estrutural de cobertura em vigas laminadas pregadas, utilizada nas construções do assentamento rural Pirituba II, em Itapeva/SP, e seu processo de escolha para esse estudo.

\subsection{Perguntas, hipóteses e objetivos de pesquisa.}

O debate de toda a revisão da literatura, a identificação de suas lacunas quanto a estudos voltados para análises pluridimensionais e sua contraposição com a realidade dentro do objeto que será estudado nesse trabalho, o ciclo de vida de um sistema estrutural de cobertura em madeira de Pinus de terceira qualidade no assentamento rural Pirituba II, trouxeram alguns questionamentos ou perguntas, que nortearão esse trabalho, direcionando assim seus objetivos para que se possa contribuir no debate colocado e na realidade estudada.

O fluxograma da figura 3 mostra as relações entre as perguntas, hipóteses e objetivos da pesquisa, elucidando através de qual questionamento foram elaboradas as hipóteses e posteriormente os objetivos a serem atingidos nesse trabalho. O fluxograma também relaciona a pergunta principal de pesquisa a algumas perguntas que a precedem, e que são necessárias para alcançar suas respostas, mostrando uma linha de perguntas precedentes (ou intermediárias), também relacionadas a suas próprias hipóteses e objetivos. 


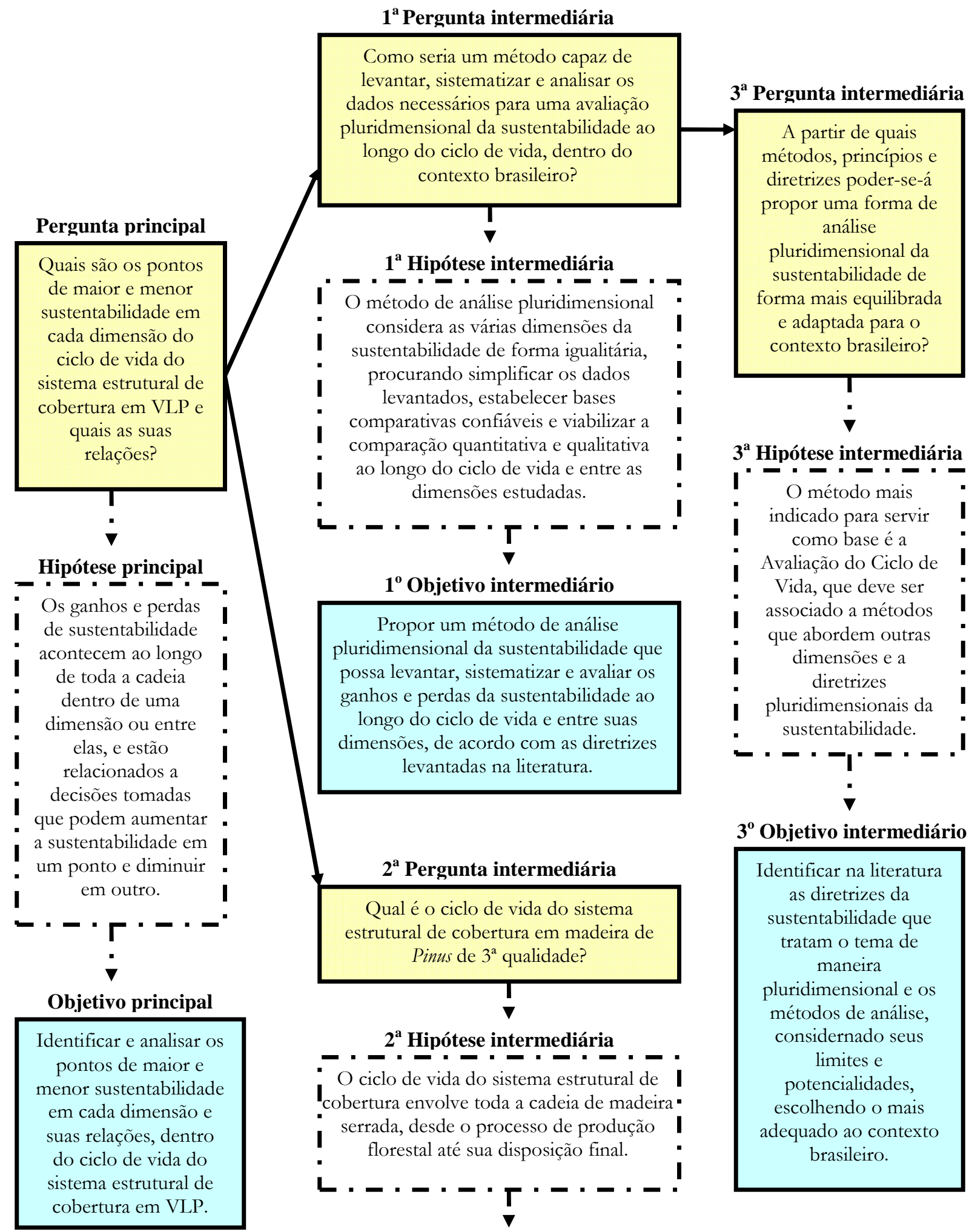

$2^{\circ}$ Objetivo intermediário

Descrever os processos e agentes envolvidos no ciclo de vida do sistema estrutural de cobertura em vigas laminadas pregadas de madeira de Pinus de $3^{\text {a }}$ qualidade.

Figura 3: Fluxograma de decomposição das perguntas, hipóteses e objetivos de pesquisa. Fonte: Autor. 
Para a resolução das questões de pesquisa, confirmação das hipóteses e alcance dos objetivos propostos foram adotadas algumas estratégias e métodos, que serão descritos no próximo item.

\subsection{Estratégia geral de pesquisa.}

Para se alcançar a análise pluridimensional do sistema estrutural de cobertura em vigas laminadas pregadas, a pesquisa foi dividida em duas etapas principais, que serão descritas nos itens abaixo:

\subsubsection{Revisão bibliográfica para elaboração do método de análise pluridimensional da sustentabilidade.}

A primeira etapa consiste no levantamento bibliográfico e análise dos conceitos da sustentabilidade e dos autores que já haviam avaliado os principais métodos de análise da sustentabilidade até o ano de 2005. Em seguida foram listados alguns objetivos que um método pluridimensional deve atingir e então escolhido o método que mais se adequaria a esse tipo de análise, já delimitando suas potencialidades e limites. Essa etapa está contida no capítulo 1.

Ainda dentro dessa etapa, são levantados quais os métodos que poderiam ser associados ao método base escolhido para ampliar sua abrangência, aproximando-se da análise pretendida. Nessa fase também são levantadas as dimensões não abordadas nos métodos estudados, acrescentando-as como indicadores qualitativos a partir da revisão da literatura do capítulo 1. Essa etapa está descrita dentro do item 3.1.2.

A última etapa para elaboração do método de análise pluridimensional da sustentabilidade é a proposição de ferramentas que auxiliem na organização e visualização dos dados, elaboradas em forma de matrizes de dados e descritas no item 3.1.2.

\subsubsection{Aplicação do método de Avaliação Pluridimensional do Ciclo de Vida em um objeto empírico.}

Essa segunda grande fase consistiu na aplicação do método adaptado para uma análise pluridimensional da sustentabilidade e avaliação de seus resultados. A aplicação do método foi feita dentro de um estudo de caso único, definido por Yin (2001) como uma investigação empírica sobre um fenômeno contemporâneo dentro de um contexto da vida real, onde o fenômeno estudado e o contexto não possuem limites definidos. Segundo o autor, o método escolhido ainda “[...] contribui para a compreensão que temos dos fenômenos individuais, 
organizacionais, sociais e políticos" e também coloca que para um estudo de caso ter confiabilidade, a coleta de evidências (inicialmente colocada como coleta de dados) deve seguir o uso de duas ou mais fontes de evidências, possuir um banco de dados com informações formais de evidências distintas, conclusões elaboradas, e sua análise possuir uma ligação explícita entre as questões levantadas, os dados coletados e as conclusões.

Assim, associando as recomendações do autor acima citado e da proposta de divisão das etapas do método de avaliação do ciclo de vida, obteve-se como resultado a estrutura de aplicação do método de avaliação pluridimensional do ciclo de vida, descrita a seguir.

I - Definição do objetivo e escopo do estudo. Fase onde são delimitados a abrangência do estudo e quais processos serão abordados (etapa que está descrita no item 3.3).

II - Levantamento do inventário. Fase do levantamento feito em campo para a formação do banco de dados. Segundo Yin (2001) existem seis possíveis fontes de evidências, sendo elas: a documentação, os registros em arquivos, entrevistas, observações diretas, observações participantes e artefatos físicos. Nesta pesquisa utilizaram-se como fontes de evidências os relatos de reuniões realizadas durante o processo de fabricação dos componentes e construção das habitações (documentação), fotografias dos eventos (documentação), registros pessoais (registro em arquivo), lista de nomes (registro em arquivo), entrevistas e observação participante nas várias atividades realizadas. Essa etapa que está descrita no item 3.4.

III - Avaliação dos impactos do ciclo de vida. Fase de ligação das questões e dados levantados no inventário com as categorias de impacto que serão analisadas, além de sua organização e exposição dos dados calculados (etapa descrita no capítulo 4).

IV - Interpretação dos dados. Fase da elaboração das conclusões a partir da análise dos dados já organizados (etapa descrita no capítulo 5).

Para a aplicação do método e de suas etapas ao longo do trabalho, será necessário saber qual o objeto será estudado, em que contexto está inserido e quais os atores envolvido em seu ciclo de vida, assunto que será abordado pelo próximo item, apresentação do objeto de estudo. 


\subsection{Apresentação do objeto de estudo}

A apresentação do objeto de estudo não abordará somente o sistema estrutural de cobertura que será estudado, mas também alguns atores envolvidos, o contexto em que está inserido e seu processo de escolha, visto que esses fatores influenciarão ou farão parte do ciclo de vida em questão.

O sistema estrutural de cobertura escolhido como objeto de estudo é um dos sistemas construtivos utilizados na construção de um conjunto de habitações que fazem parte do projeto denominado INOVARURAL, coordenado pelo grupo de pesquisa em Habitação e Sustentabilidade (Habis, EESC/USP - UFSCar). Esse projeto de pesquisa/ensino/extensão tinha como objetivo construir 49 unidades habitacionais em um assentamento rural em Itapeva/SP, com inovações no processo e gestão, contando com a formação e participação das famílias em todas as etapas, e nos produtos, utilizando recursos locais e renováveis para atingir uma maior sustentabilidade.

O projeto baseou-se no método de "pesquisa-ação", que é definida por Thiollent (1986 apud Silva, F. 2006) como:

[...] um tipo de pesquisa social com base empírica que é concebida e realizada em estreita associação com uma ação ou com a resolução de um problema coletivo no qual os pesquisadores e os participantes representativos da situação ou do problema estão envolvidos de modo cooperativo ou participativo.

Assim, todo o projeto foi baseado em uma intervenção na realidade social, e a pesquisa desenvolvida pelo grupo foi definida e delimitada ao longo do processo de intervenção, fazendo com que, ao mesmo tempo em que a pesquisa interferisse nas resoluções dos problemas da realidade, também interferisse em suas metas, hipóteses e objetivos. Assim coloca-se como fundamental entender o processo de delimitação desse objeto durante a pesquisa realizada, o que será feito nos itens a seguir.

\subsubsection{O processo de escolha da região de Itapeva e do assentamento Pirituba II como local de estudo.}

O município de Itapeva, onde está localizado o objeto de estudo, situa-se na Região Sudoeste do Estado de São Paulo e está inserido na região administrativa de Sorocaba, em um contexto de grande disponibilidade florestal em contraste aos seus baixos indicadores sociais. 
Essa região é detentora de $42,3 \%$ de todo o plantio florestal do estado, e de $58,5 \%$, quando se trata apenas do plantio de Pinus (figura 4), o que significa, somente para o município de Itapeva, um total de 22.532 ha de áreas plantadas.

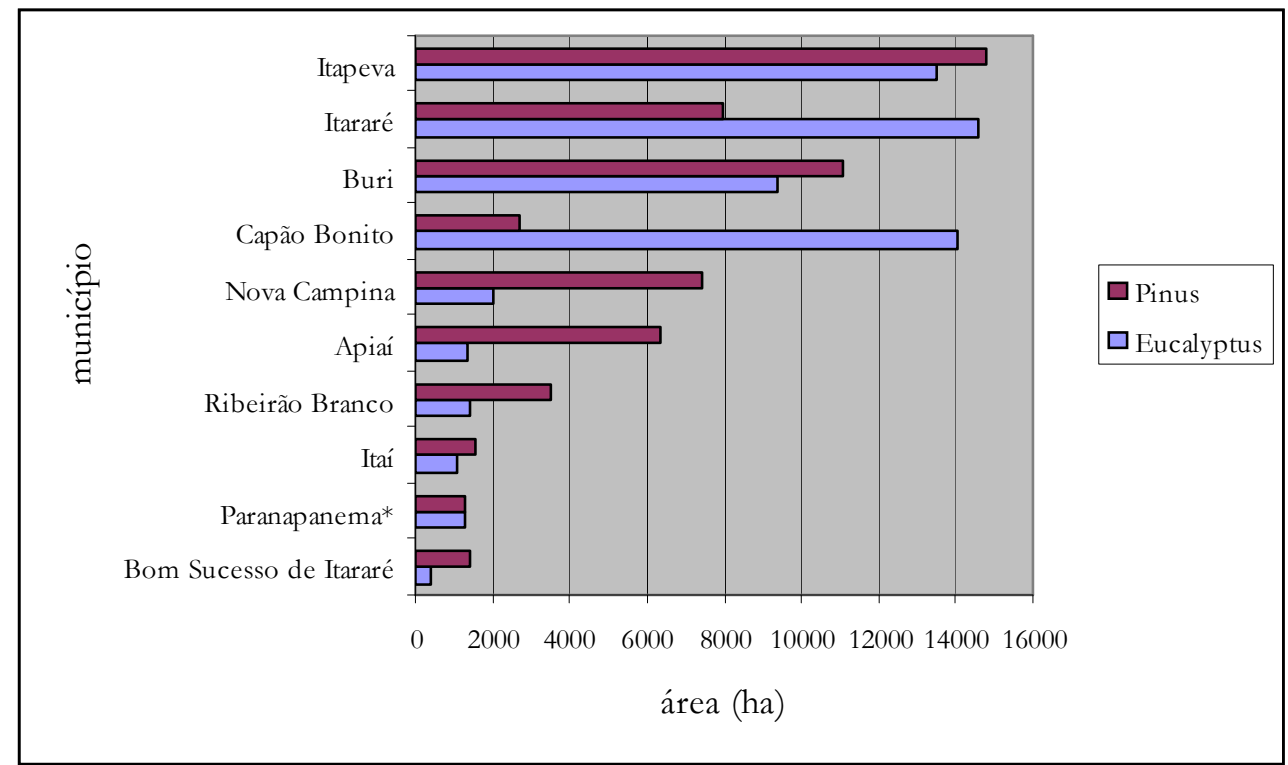

Figura 4: Área plantada dos dez municípios com quantidades mais expressivas no Pólo de Reflorestamento de Itapeva/ Capão Bonito/ Buri.

Fonte: RELATÓRIO TRIMESTRAL DO PROJETO DE PESQUISA (2005) adaptado de KRONKA, (2002).

Em contrapartida à disponibilidade de matérias-primas renováveis, tem-se o cenário de pobreza desses municípios, caracterizado por índices apresentados pelo SEBRAE, em geral muito abaixo da média do Estado de São Paulo. Na educação, a taxa de analfabetismo é de 15,21\% da população e, apesar dos municípios oferecerem do ensino básico ao universitário, a população jovem tende a procurar outros municípios para o ensino público de nível técnico e superior, diminuindo a cada ano a taxa de crescimento populacional dos municípios dessa região.

Outro indicador que caracteriza a situação social dos municípios é o Índice de Desenvolvimento Humano (IDH), que pode ser visto na figura 5, onde os índices mais baixos são representados pelas áreas em vermelho. 


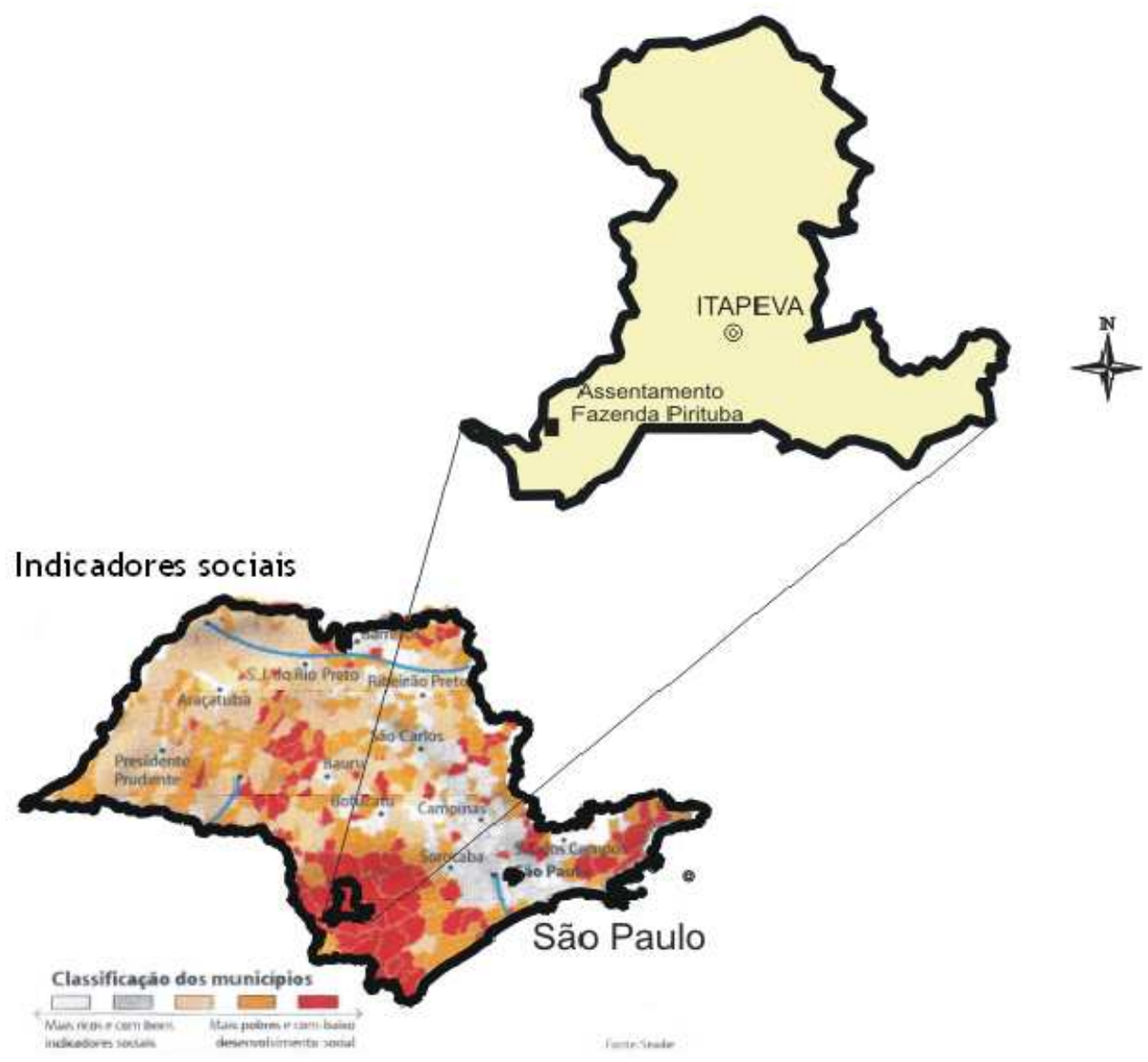

Figura 5: Índice de desenvolvimento humano no estado de São Paulo. Fonte: Shimbo, L. (2004).

Segundo dados do SEADE (SEADE, 2003), no setor agropecuário, a média da remuneração dos trabalhadores dessa região (3,23 SM, tomando-se como base o município de Itararé) é muito abaixo do que a média salarial do Estado de São Paulo (6,68 SM), em todos os níveis de instrução.

Partindo-se desse contexto, o grupo de pesquisa Habis iniciou suas atividades de pesquisa e intervenção na realidade dessa região unindo a demanda habitacional rural do município de Itapeva e a disponibilidade da madeira como matéria-prima para a construção das mesmas, através do projeto de políticas públicas denominado "Habitação social em madeira de reflorestamento como alternativa econômica para usos múltiplos da floresta”, financiado pela FAPESP (processo no 98/14124-1), que abrangia três áreas de estudo:

- reposição florestal: agricultura familiar e criação e fortalecimento da articulação entre as famílias, Estado, cadeia produtiva da madeira e assessoria; 
- habitação social: participação das famílias, criação e fortalecimento da articulação entre as famílias, Estado, cadeia produtiva da madeira e assessoria e a inovação de técnicas e de formas de gestão;

- geração de trabalho e renda: economia solidária e inovação de técnicas e de gestão.

O projeto de políticas públicas teve condições favoráveis na implementação de algumas das metas previstas, principalmente relativas à habitação social e geração de trabalho e renda, com a demanda por construção de novas unidades habitacionais no Assentamento Rural Pirituba II, localizado nos municípios de Itaberá e Itapeva, que foi levada para o grupo Habis através de uma lista de famílias do assentamento que reivindicavam moradias para o Instituto de Terras do Estado de São Paulo (ITESP). Em fevereiro de 2004, as famílias desse assentamento foram contempladas com um financiamento para a construção de 49 unidades habitacionais dentro do Programa de Subsídio à Habitação de Interesse Social (PSH), vinculado ao Ministério das Cidades, a partir de um convênio entre Caixa Econômica Federal (CEF) e Incra (Instituto de Colonização e Reforma Agrária).

O desafio colocado nesse processo de construção foi a redução de custos da habitação, procurando-se enquadrar um projeto com maior área e melhor qualidade dentro dos valores de financiamentos públicos para habitação social, além das metas já colocadas pelo projeto de políticas públicas nas áreas de habitação e geração de renda. Considerando-se então a grande quantidade de plantios florestais da região, optou-se pela madeira como alternativa de material construtivo para a produção de habitação social, por ser um material disponível, renovável e de fácil e rápida montagem.

Para Ino, (1997b) na fase de construção das unidades habitacionais no canteiro de obras, a madeira permite a montagem de alguns componentes pré-fabricados, de fácil aprendizagem das técnicas de montagem pelos usuários em tempo menor, comparado aos sistemas convencionais, com possibilidade de redução de custos, uso intensivo de mão de obra, baixo investimento de bens de capital e possibilidade de alternativa econômica para geração de renda.

Assim, possibilitou-se a utilização de recursos locais e a produção de componentes construtivos pelas próprias famílias, conciliando-se produção de habitação e atividades de geração de trabalho e renda, condizentes com o objetivo geral do Projeto. 


\subsubsection{O assentamento Pirituba II e sua organização para construção das habitações.}

A Fazenda Pirituba abrange uma área de 17.500 ha localizada nos municípios de Itapeva e Itaberá e sua história é marcada por diversos conflitos e processos judiciais relativos à propriedade da terra e sua ocupação, com a formação, em 1984, do Assentamento Rural Pirituba II - um dos projetos implementados pelo Plano de Valorização de Terras Públicas (PVTP - governo Franco Montoro) em que as famílias assentadas obtêm a cessão de uso da terra com todas as condições de uso de um proprietário (inclusive na questão da herança) e, embora ainda pertença ao Estado, é garantida que sempre terá o uso para a reforma agrária.

A área do assentamento em questão é cortada por uma estrada estadual pavimentada, com ruas não pavimentadas de acesso aos lotes, com terras para lavoura, áreas de preservação ambiental, nascentes e rio, onde cada família assentada ocupa um lote de campo (ou lote de plantio, com área aproximada de 16ha) e um lote de moradia (ou lote de agrovila, com área de 1ha). Os lotes de moradia são agrupados em agrovilas que funcionam como centros de cada área e contam com duas escolas (da creche ao ensino fundamental) e um posto de saúde como equipamentos coletivos.

Até o momento da intervenção do grupo Habis, dezoito anos após a cessão do direito de uso da terra, a maioria das habitações ainda se encontrava em condições precárias (construídas com costaneiras de madeira, papelit e tábuas já deterioradas) e com muitos problemas de infraestrutura, com abastecimento de água proveniente de nascente ou de poço comum (em muitos pontos, já contaminada) e sem coleta e tratamento de esgoto (águas negras: fossa negra; águas cinzas: escoamento direto).

Para conhecer melhor tanto a situação socioeconômica quanto as condições de infra-estrutura e de habitação das famílias assentadas, a equipe de pesquisadores visitou cerca de setenta casas, onde foi aplicado um questionário, abrangendo questões sobre educação, trabalho e renda, produção agrícola, dívidas, terra e habitação, lazer e comunidade, além da observação direta da condição das habitações.

Sistematizados os dados, foram confirmados os principais problemas levantados pelas famílias durante as reuniões, apresentados parcialmente no quadro 5. 
Quadro 5: Levantamento socioeconômico e das condições de infra-estrutura e de habitação

\begin{tabular}{|l|l|}
\hline \multicolumn{1}{|c|}{ Índices } & \multicolumn{1}{c|}{ Dados levantados } \\
\hline Renda & $\begin{array}{l}\text { - } 86 \% \text { das famílias possui renda inferior a } 2 \text { salários mínimos (dos quais } \\
44 \% \text { recebem até 1 salário). }\end{array}$ \\
\hline Inadimplência & $\begin{array}{l}\text { - } 80 \% \text { têm alguém inadimplente na família (dívida adquirida em projetos } \\
\text { de financiamento agrícola). }\end{array}$ \\
\hline Ocupação profissional & - $51 \%$ trabalham somente em lavoura própria; \\
& - $24 \%$ trabalham em lavoura própria e como diarista. \\
\hline \multirow{2}{*}{ Escolaridade } & - $47 \%$ freqüentou $1^{\circ}$ a $4^{\circ}$ série (ens. fundamental); \\
& - $28 \%$ freqüentou $5^{\circ}$ a $8^{\circ}$ série (ens. fundamental); \\
& - $12 \%$ freqüentou ensino médio; \\
\hline
\end{tabular}

Fonte: adaptado do grupo de pesquisa Habis.

A situação das habitações e das condições de higiene e infra-estrutura foi considerada precária, através da observação direta e de registros fotográficos (figura 6).
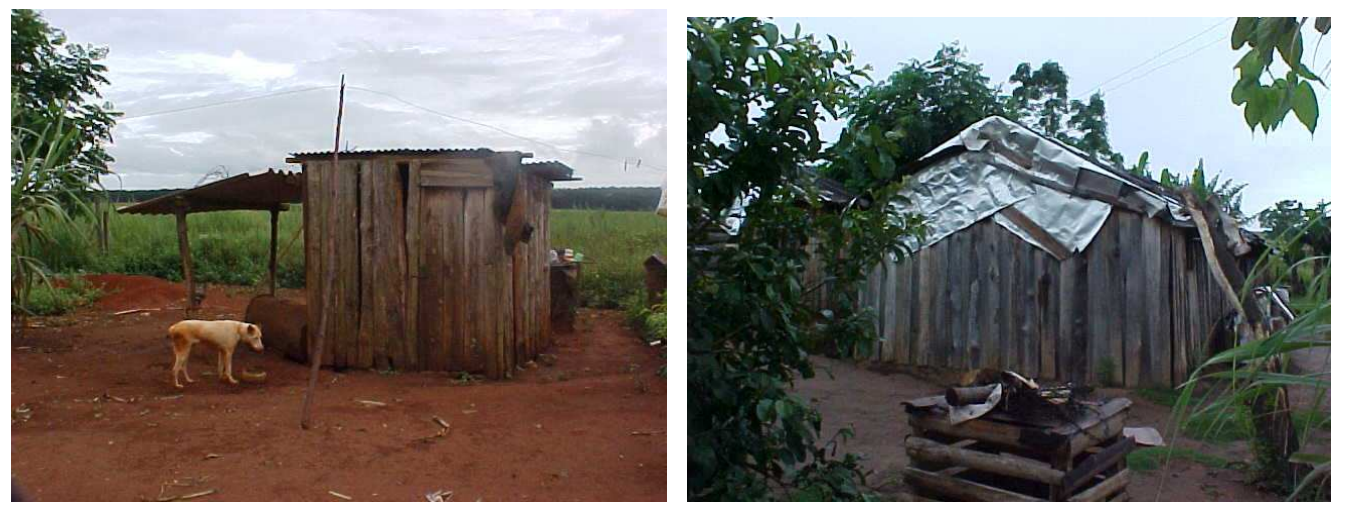

Figura 6: Seqüência de fotos das habitações do assentamento Pirituba II antes do projeto de construção de moradias (janeiro de 2003).

Fonte: Grupo de pesquisa Habis.

Para atender a demanda de construção das casas, cerca de oitenta famílias participaram de assembléias que discutiam a questão da habitação, e foram divididas em sete subgrupos que elegeram seus respectivos representantes para a formação da Coordenação Geral, que também contava com a participação dos pesquisadores, representantes do ITESP e outras lideranças convidadas. Nas reuniões realizadas foram discutidas, principalmente, as alternativas de financiamento para a construção das habitações e a organização interna da coordenação (papel dos participantes, fundo financeiro, tesoureiro, moderadores).

O grupo então conquistou um financiamento para as habitações pela primeira portaria do PSH, efetivada por um Termo de Cooperação Técnica entre CEF e Incra, onde parte dos recursos era subsidiada (com recursos da CEF, valor máximo do subsídio: $\mathrm{R} \$ 4.500,00$ ) e a outra parte era financiada pelo Incra (valor máximo do financiamento: $\mathrm{R} \$ 5.000,00$ ), cujo pagamento é feito em 
seis parcelas anuais, sem juros e, caso fossem pagas dentro do prazo, com desconto de $50 \%$ no seu valor. Das 80 famílias, 49 assinaram o contrato desse convênio e formaram o Grupo das Casas; o restante optou por outro financiamento, não participando mais do projeto. Esse processo é descrito na dissertação "A casa é o pivô", de Shimbo, L. (2003).

\subsubsection{A escolha da arquitetura e dos sistemas construtivos.}

$\mathrm{Na}$ fase de definição da arquitetura e escolha dos sistemas construtivos, o grupo Habis adotou como estratégia geral a participação das famílias, com a perspectiva de se experimentar uma nova alternativa de gestão para programas de habitação social, procurando assim, aumentar a sustentabilidade do projeto. As famílias participaram das tomadas de decisões da concepção e elaboração do programa de necessidades, planta arquitetônica, volumetria e materiais construtivos através de dinâmicas feitas em assembléias ou grupos menores onde as famílias e técnicos contrapunham suas experiências e debatiam sobre as decisões a serem tomadas, resultando em um projeto arquitetônico que atendesse todos os requisitos técnicos mínimos e ao mesmo tempo correspondesse aos anseios e valores culturais das famílias. O resultado da discussão arquitetônica resultou nas plantas ilustradas na figura 7.
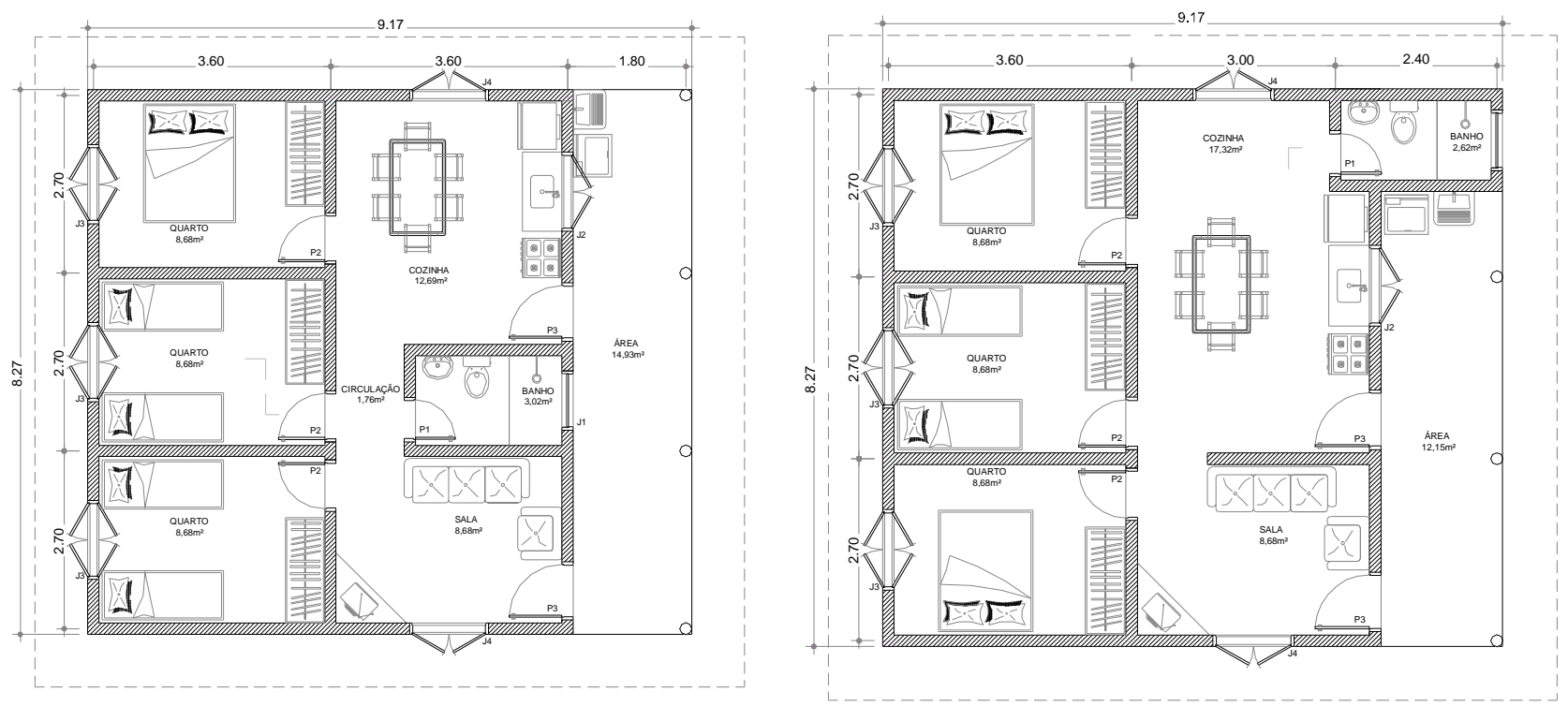

Figura 7: plantas baixas definidas com a participação das famílias.

Fonte: Grupo de pesquisa Habis.

Em uma das dinâmicas realizadas entre famílias e assessores foram apresentados os diferentes materiais construtivos e suas características (durabilidade, aparência, confecção, possibilidade de gerar renda, se eram poluentes e se eram repostos na natureza) e, diante do questionamento sobre o custo dos materiais e o custo final da casa, os assessores apresentaram dados comparativos 
entre os materiais sugeridos para o meio urbano pela CDHU (Programa Habiteto) e os materiais utilizados pelo Habis (madeira e terra), com o objetivo de mostrar que as casas construídas com materiais alternativos poderiam ser maiores $\left(60 \mathrm{~m}^{2}\right.$, corpo principal da casa $+15 \mathrm{~m}^{2}$ de varanda $=75 \mathrm{~m}^{2}$ ) com o mesmo valor do financiamento da CDHU $\left(43 \mathrm{~m}^{2}\right)$, respeitando o projeto arquitetônico definido pelas famílias. O maior custo das habitações estava na vedação e na cobertura, por isso os assessores estudaram alternativas de uso de materiais mais econômicos sem perda de qualidade (como o adobe e a madeira de Pinus de terceira qualidade), e que pudessem também dar a oportunidade de gerar trabalho e renda para as famílias (figura 8).
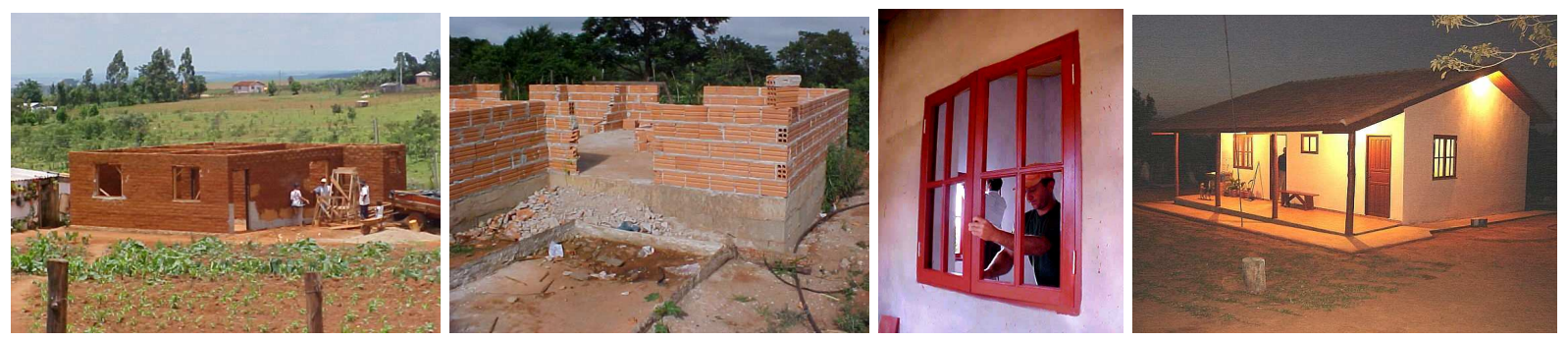

Figura 8: Seqüência de fotos de alguns sistemas construtivos escolhidos, adobe, bloco cerâmico esquadrias de madeira de reflorestamento e a casa acabada; da esquerda para a direita respectivamente.

Fonte: Grupo de pesquisa Habis.

Essas questões, que eram metas do Projeto InovaRural, deram espaço para a concretização de um empreendimento autogestionário dentro do assentamento, a Marcenaria Madeirarte, criada com o propósito de fornecer as esquadrias e coberturas em madeira para as habitações do Assentamento Rural Pirituba II, e com a possibilidade de atender novas demandas posteriormente.

\subsubsection{Formação da marcenaria coletiva autogestionária.}

Para viabilizar a implementação de fabricação de componentes em madeira de Pinus, constituiu-se um grupo de pessoas interessadas na capacitação em gestão de empreendimentos autogestionários e nos serviços qualificados de processamento da madeira. O objetivo principal era capacitar as famílias para o ofício de marceneiro e produzir os componentes de madeira de todas as habitações do programa, recebendo em forma de troca de serviços com outros mutirantes a execução de todas as outras etapas de construção de suas casas. Essa marcenaria teria o intuito de, posteriormente, gerar trabalho e renda aos assentados que fossem capacitados durante esse processo.

A aquisição de máquinas e ferramentas para dar início ao funcionamento da marcenaria foi obtida com recursos do Fundo de Cultura e Extensão da USP e da premiação de $1^{\circ}$ lugar no III Prêmio Mostra PUC - Rio de Janeiro (na categoria técnico-científica para projetos de extensão 
universitária). Os equipamentos adquiridos foram cedidos ao grupo de interessados para iniciar a produção dos componentes construtivos para as 49 unidades habitacionais e o barracão, localizado no assentamento, para implantar a Marcenaria foi cedido pelo ITESP.

Tendo em vista os componentes construtivos para as 49 unidades habitacionais, a capacitação e a produção foram estruturadas em duas fases: fabricação de esquadrias com madeira de eucalipto e fabricação de componente para cobertura com Pinus de $3^{\text {a }}$ qualidade.

O grupo de pessoas interessadas em participar da marcenaria coletiva foi formado a partir de indicações de nomes durante assembléias no segundo semestre de 2003. Foram colocados como critérios de seleção o interesse das pessoas em aprender o ofício e a vontade de continuar no empreendimento após o fim da construção das habitações, pois desde o início colocou-se a possibilidade de continuidade do empreendimento com a perspectiva de geração de trabalho e renda para as famílias assentadas. Esses critérios, que inicialmente levaram à formação de um grupo de dez pessoas, foram alterados em fevereiro de 2004, com o início das atividades de canteiro para construção das casas, pois houve uma série de desistências no grupo inicialmente formado, segundo alguns participantes pela insegurança da troca de serviço com outros mutirantes. Com um grupo inicial reduzido adotou-se o critério de que cada grupo de trabalho em canteiro deveria ter um representante que trabalhasse na marcenaria, mas após alguns meses esse novo acordo também foi quebrado, resultando na formação de um grupo permanente de três mulheres, um marceneiro instrutor e um jovem aprendiz, chamado de "auxiliar", que assumiram toda a produção dos componentes em madeira do projeto InovaRural.
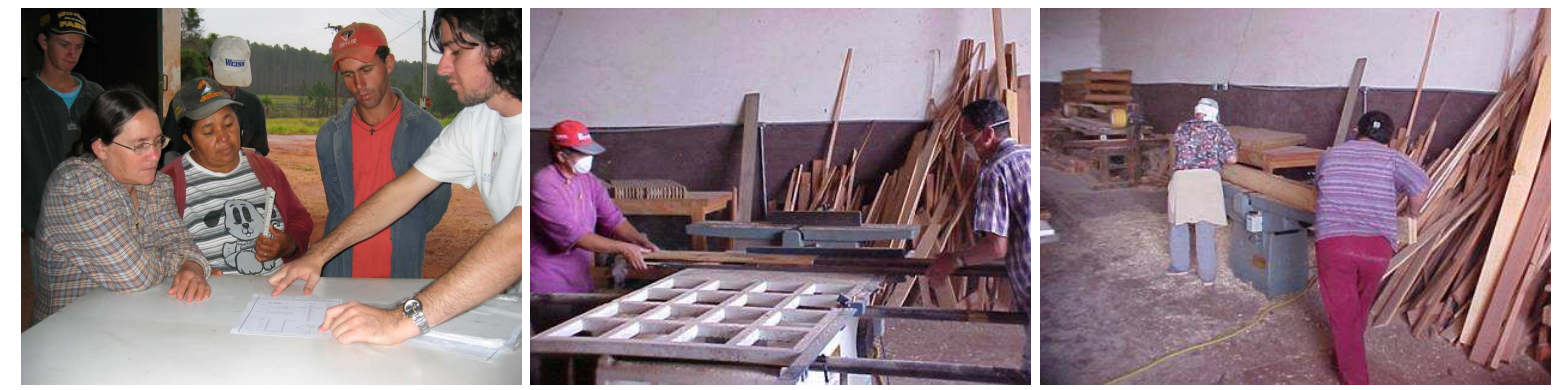

Figura 9: Seqüência de fotos do grupo da marcenaria sendo capacitado pelos técnicos, marceneiro instrutor e trabalhando na produção de componentes; da esquerda para a direita respectivamente.

Fonte: Grupo de pesquisa Habis.

\subsubsection{Descrição do sistema estrutural em Vigas Laminadas Pregadas.}

A partir das discussões coletivas com as famílias e do cenário de criação de uma marcenaria coletiva, foi desenvolvido o sistema estrutural de cobertura que seria utilizado nas habitações do 
assentamento rural Pirituba II. O primeiro ponto considerado para a definição do projeto foi a mão-de-obra que executaria a produção dos componentes e instalaria o sistema no canteiro de obras, pois em um sistema de cobertura de madeira convencional (tesouras, terças, caibros e ripas) existe a necessidade da mão-de-obra especializada de um carpinteiro para sua execução. Como nesse caso a obra seria executada pelas próprias famílias beneficiárias através do sistema de mutirão (não existindo recursos para a contratação de um carpinteiro), procurou-se priorizar a pré-fabricação dos componentes na marcenaria, onde existiriam pessoas capacitadas para executar trabalhos mais complexos, deixando o mínimo de operações possíveis para serem realizadas no canteiro de obras, facilitando assim a instalação das coberturas nas habitações por pessoas com menos experiência.

Em segundo lugar foi considerada a disponibilidade da madeira na região, através de um levantamento das serrarias existentes nas proximidades, verificando-se o preço e os tipos de madeiras disponíveis (o grupo de pesquisa Habis deu prioridade às madeiras de Pinus e de Eucalipto de plantios florestais, visto que as madeiras nativas não possuíam certificado de manejo florestal), e constatou-se que grande parte da madeira produzida era destinada à exportação e as madeiras comercializadas no Brasil eram de uma qualidade inferior, entre elas havia peças disponíveis de Pinus de $3^{\text {a }}$ qualidade, de baixo custo e de pequenas dimensões.

Esses pontos considerados, somado ao caráter social do projeto, devendo portanto ser economicamente viável, fizeram com que a equipe pensasse em uma maneira de utilizar essas peças, que não possuíam valor comercial, agregando-lhes valor e fazendo com que pudessem ser utilizadas na construção civil, melhorando o aproveitamento das toras que antes eram subutilizadas.

Durante o processo projetual foram desenvolvidas cinco propostas de componentes para o sistema estrutural de cobertura, sendo que as decisões técnicas e projetuais contaram com a participação dos técnicos do grupo de pesquisa, dos técnicos do laboratório que produziu os protótipos dos componentes e das famílias, que participaram da capacitação para serviços de marcenaria durante a produção dos protótipos e davam suas opiniões como futuros moradores e fabricantes dos componentes pré-fabricados. Assim, o projeto final foi um sistema estrutural de cobertura que utiliza as lâminas de Pinus disponíveis no mercado, com seções de, em média, 190 centímetros de comprimento por 14 centímetros de largura e 1,2 centímetros de espessura, justapostas em uma mesa de gabarito e pregadas, para adquirirem seções robustas o suficiente para o fim estrutural, mudando o sistema de madeiramento tradicional de ripas, caibros e terças para uma viga única, denominada VLP simples, de seção 3,6 x 13,5 cm e comprimento de 2,7 $\mathrm{m}$ 
(para vão simples) ou 3,4 $\mathrm{m}$ (para vão de 2,7 $\mathrm{m}$ mais o beiral), posicionadas no mesmo espaçamento das ripas. As tesouras, vigas e mãos-francesas também foram substituídas por novos componentes, a viga laminada pregada (VLP) composta, VLP da varanda e VLP do beiral, respectivamente. Todos os novos componentes foram pré-fabricados a partir da justaposição e pregação das mesmas lâminas de Pinus de terceira qualidade utilizadas para a fabricação da VLP simples.

Na figura 10 é mostrada uma seqüência de fotos com as laminas de Pinus utilizadas e parte da fabricação dos componentes.
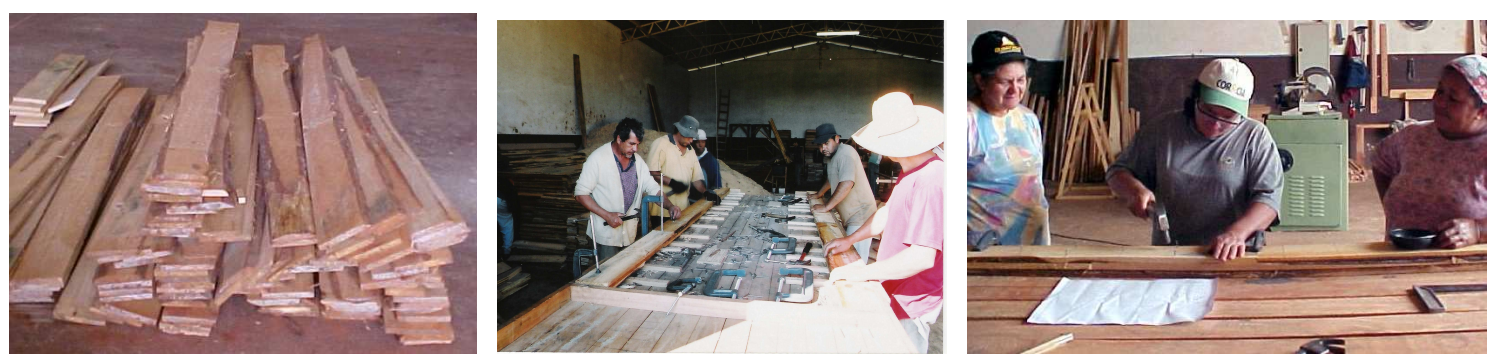

Figura 10: Seqüência de fotos das laminas de Pinus de terceira qualidade, da etapa de posicionamento das peças na mesa de gabarito e pregação, da esquerda para direita respectivamente. Fonte: Valle (2007).

A figura 11 mostra um desenho que representa um sistema estrutural de cobertura convencional e a figura 12 um desenho que representa o sistema em vigas laminadas pregadas. A figura 13 mostra os diferentes componentes do sistema estrutural e como são compostas as suas diferentes camadas de lâminas. 


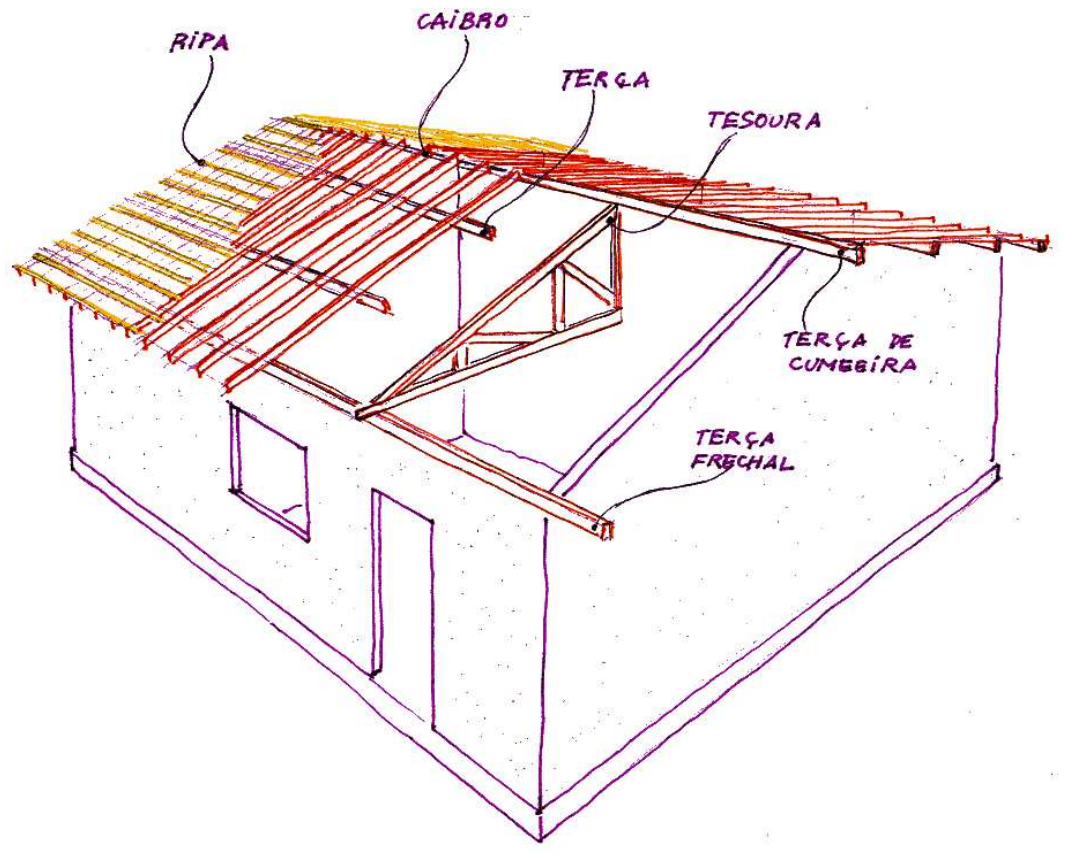

Figura 11: Desenho esquemático de um sistema estrutural de cobertura convencional com ripas, caibros, terças e tesoura.

Fonte: Valle, $(2008)^{2}$

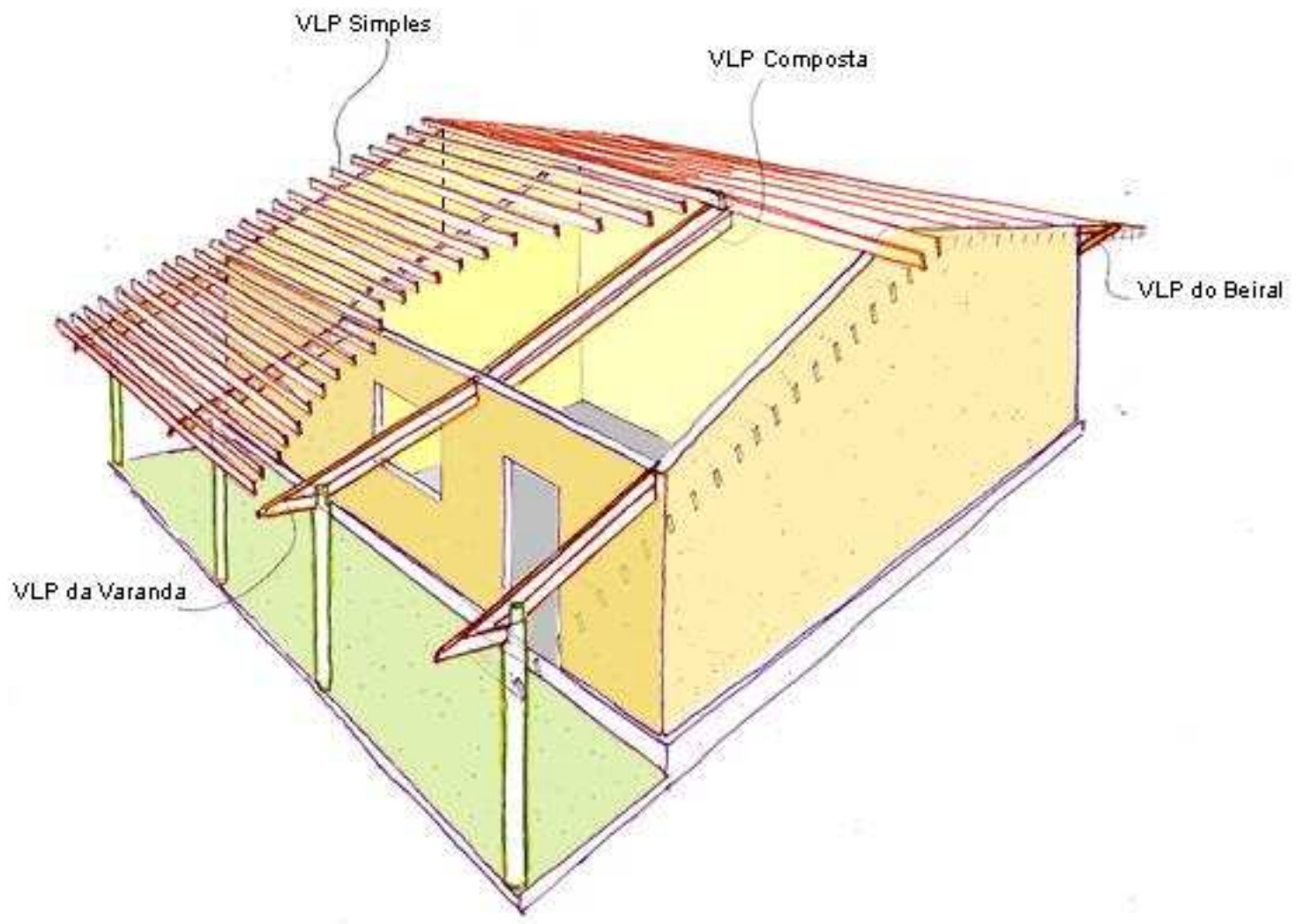

Figura 12: Desenho esquemático de um sistema estrutural de cobertura em vigas laminada pregadas. Fonte: Valle, $(2008)^{2}$.

2 Desenhos cedidos por Ivan Manoel Rezende do Valle. 

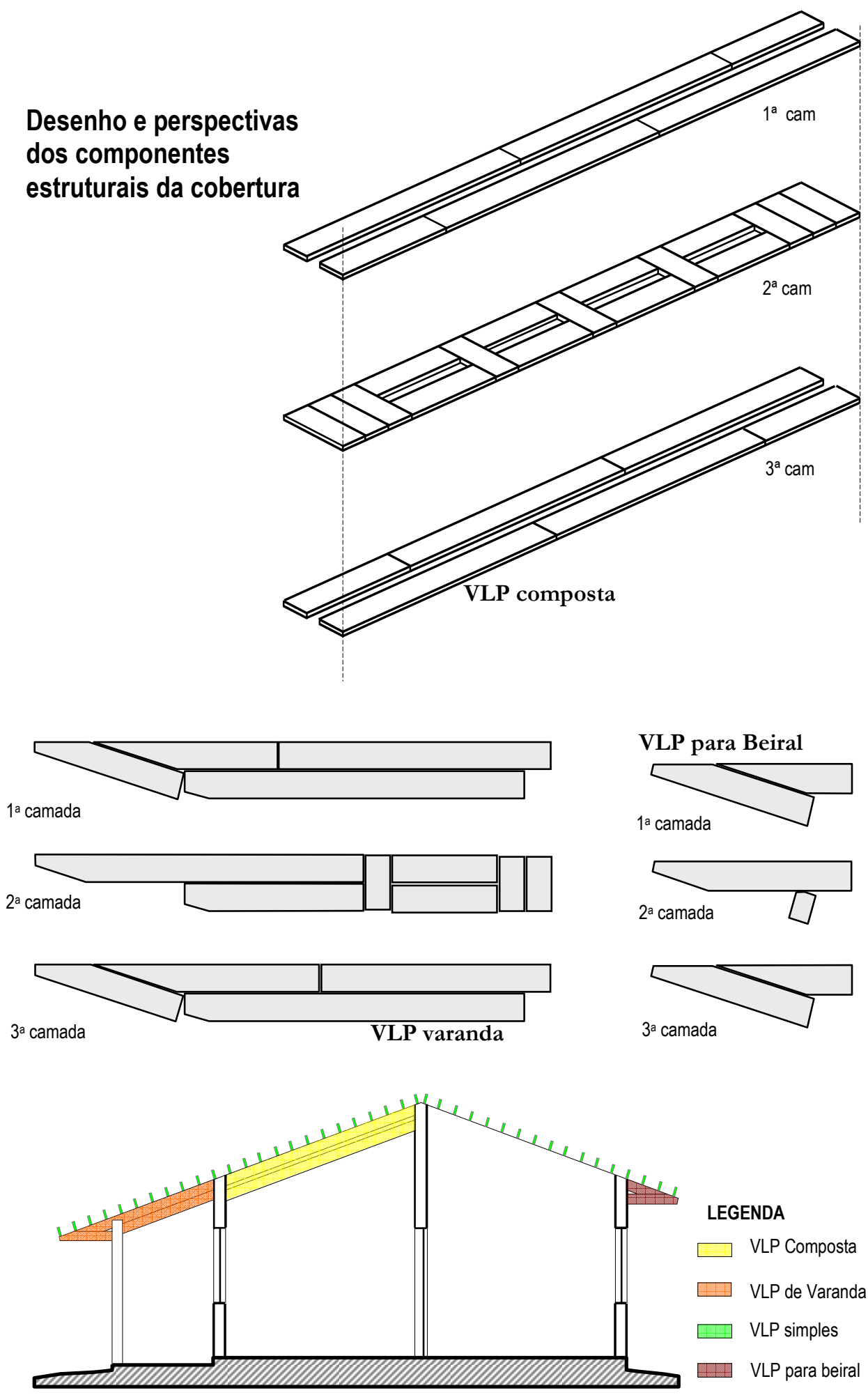

Figura 13: Desenhos de alguns componentes do sistema de cobertura. Fonte: Valle, (2008) ${ }^{3}$.

${ }^{3}$ Desenhos cedidos por Ivan Manoel Rezende do Valle. 
A fixação das vigas compostas, de beiral e de varanda, e das VLP simples de 2,7 m e 3,4 m foram feitas através de sua fixação em chapuzes e peças de madeira chamadas de berços. Os berços eram peças de madeira de Pinus de seção $1,6 \times 14 \mathrm{~cm}$ aparafusadas ao longo dos oitões da alvenaria e os chapuzes eram peças de eucalipto em forma de triângulos retos de $10 \mathrm{x} 10 \mathrm{x} 14 \mathrm{~cm}$ com $4 \mathrm{~cm}$ de espessura onde eram pregadas as VLP simples nos berços, com espaçamento das galgas das telhas cerâmicas que foram utilizadas. Além dos componentes de madeira também é necessário fazer um travamento do sistema estrutural com um cabo de aço, que é transpassado pelas VLP simples, tencionado e travado com espaçadores, que são peças de madeira de eucalipto de seção 4 x $4 \mathrm{~cm}$ e comprimento de $27 \mathrm{~cm}$. A figura 14 traz uma foto da fixação da VLP simples em um berço através da pregação do chapuz e do sistema de travamento da estrutura.
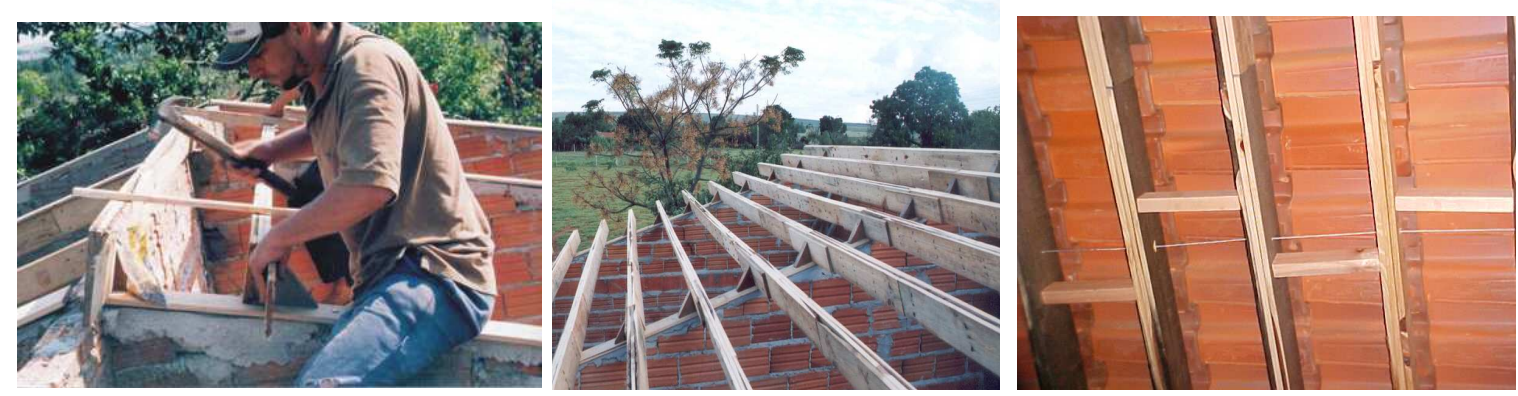

Figura 14: Seqüência de fotos da fixação da VLP simples em um berço através da pregação do chapuz, sistema já fixado e do travamento da estrutura, da esquerda para a direita respectivamente.

Fonte: Valle, $(2008)^{4}$.
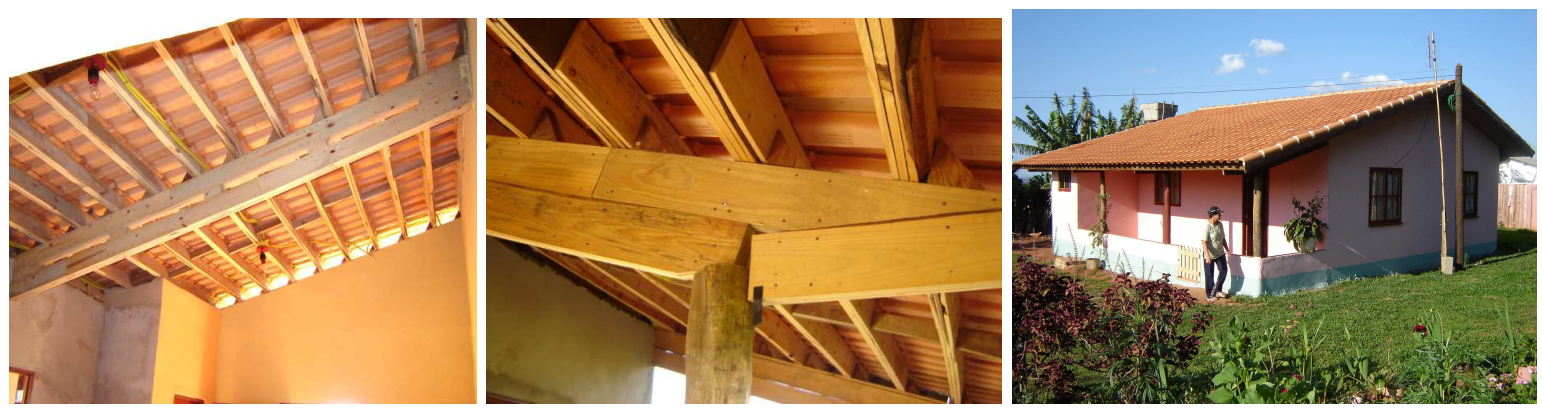

Figura 15: Seqüência de fotos do sistema estrutural em vigas laminadas pregadas já montadas na obra com as telhas cerâmicas, e aparência final do sistema com a casa acabada.

Fonte: Valle (2008)

O desenho executivo comleto do sistema estrutural de cobertura em vigas laminadas pregadas está contido no Anexo III, fornecido em CD.

\footnotetext{
${ }^{4}$ Fotografias cedidas por Ivan Manoel Rezende do Valle.
} 


\section{Capítulo 3}

\section{Adaptação e aplicação do método de Avaliação do ciclo de vida no sistema estrutural de cobertura em VLP}

Nesse capítulo serão feitas a adaptação e a associação do método base escolhido, ACV, a outro método e variáveis retiradas da literatura para permitir uma análise das dimensões ambiental, social, política, econômica e cultural mais balanceada, verificando suas relações de ganho e perda ao longo da cadeia e entre as dimensões estudadas. Para isso foram esclarecidas as estruturas do método de avaliação do ciclo de vida e do método da análise socioeconômica que será estudado, indicando suas limitações de cada um e propondo a associação de novas variáveis e ferramentas. Posteriormente a análise pluridimensional do ciclo de vida será aplicada ao objeto de estudo, a estrutura de cobertura em vigas laminadas pregadas pré-fabricadas e montadas em sistema de mutirão.

Durante a aplicação do método nesse capítulo serão definidos os objetivos do estudo e seu escopo, que indica a abrangência do estudo a ser feita com suas unidades de referência, utilizadas para uma futura comparação, e será feita a explicitação do método de levantamento dos dados do inventário, ressaltando os processos e etapas envolvidos e as bases de cálculo que serão utilizadas para relacionar os dados levantados com as categorias de impacto da fase de análise dos dados.

\section{1. - Adaptação do método de avaliação do ciclo de vida visando um instrumento de análise pluridimensional.}

Para que seja feita a revisão do método de avaliação do ciclo de vida é necessário entender seu funcionamento e estrutura, para só então incluir novas variáveis para uma análise pluridimensional. Assim, a revisão do método será feita em três etapas: a apresentação da estrutura convencional do método ACV, a apresentação do método socioeconômico, das variáveis de outras dimensões e das novas ferramentas a serem associadas ao método base, e revisão do método ao longo de sua aplicação no objeto empírico (para detectar os limites do método proposto durante sua aplicação prática, possibilitando a revisão dos mesmos). 


\subsection{1 - Estrutura do método de avaliação do ciclo de vida.}

Para que se possa reformular o modo como a avaliação do ciclo de vida é feita, será necessário entender seu funcionamento e algumas definições para que, através da proposição de novas ferramentas e variáveis, se tenha uma análise mais equilibrada das diferentes dimensões. Uma das principais características desse tipo de análise é sua abrangência, neste caso o "ciclo de vida", cuja definição é: "estágios sucessivos e encadeados de um sistema de produto, desde a aquisição da matéria prima ou geração de recursos naturais até a disposição final” (ABNT, 2001), denominado por alguns autores como "berço ao túmulo", ou mesmo "do berço ao berço", eliminando a idéia de disposição final e acrescentando a de reciclagem em seu conceito (YUBA, 2005).

Portanto, o ciclo de vida seria formado pelos diferentes estágios do "sistema do produto", termo utilizado para expressar um "conjunto de processos elementares, conectados por fluxos de produtos intermediários, que realizam uma ou mais funções definidas", e que "inclui processos elementares, fluxos elementares, fluxos de produto através da fronteira do sistema (para dentro do sistema ou para fora dele) e fluxo de produtos intermediários dentro do sistema”, (ABNT, 2004), referindo-se não somente a produtos físicos, mas também a sistemas de serviços.

Assim pode-se dividir o sistema do produto em quantos processos elementares forem necessários, como por exemplo, o sistema da produção de vigas em madeira pode ser dividido em processo de produção florestal, processo de beneficiamento da madeira e processo de comercialização; sendo que esses processos elementares ainda podem ser subdivididos quantas vezes forem necessárias e estarão sempre ligados por fluxos, que podem ser de três tipos:

- Fluxos elementares: material ou energia que entra em um sistema ou processo por meio de retirada do meio ambiente sem transformação humana prévia. Ou material ou energia que deixa um sistema ou processo por descarte no meio ambiente sem transformação humana subseqüente. Ex.: água da chuva e energia solar para o processo de produção florestal.

- Fluxos de produtos: material que entra em um sistema de produto previamente transformado pelo homem. Ex.: fertilizantes e agrotóxicos para o processo de produção florestal.

- Fluxos de produtos intermediários: material que entra em um processo elementar de um sistema de produto para outro sistema elementar do mesmo sistema, havendo transformações do homem nesses processos. Ex.: toras que saem do processo de produção florestal para o processo de beneficiamento (ABNT, 2004). 
Um exemplo de entradas e saídas dos fluxos de produtos, produtos intermediários e fluxos elementares dentro de um sistema de produto pode ser visto na figura 16.

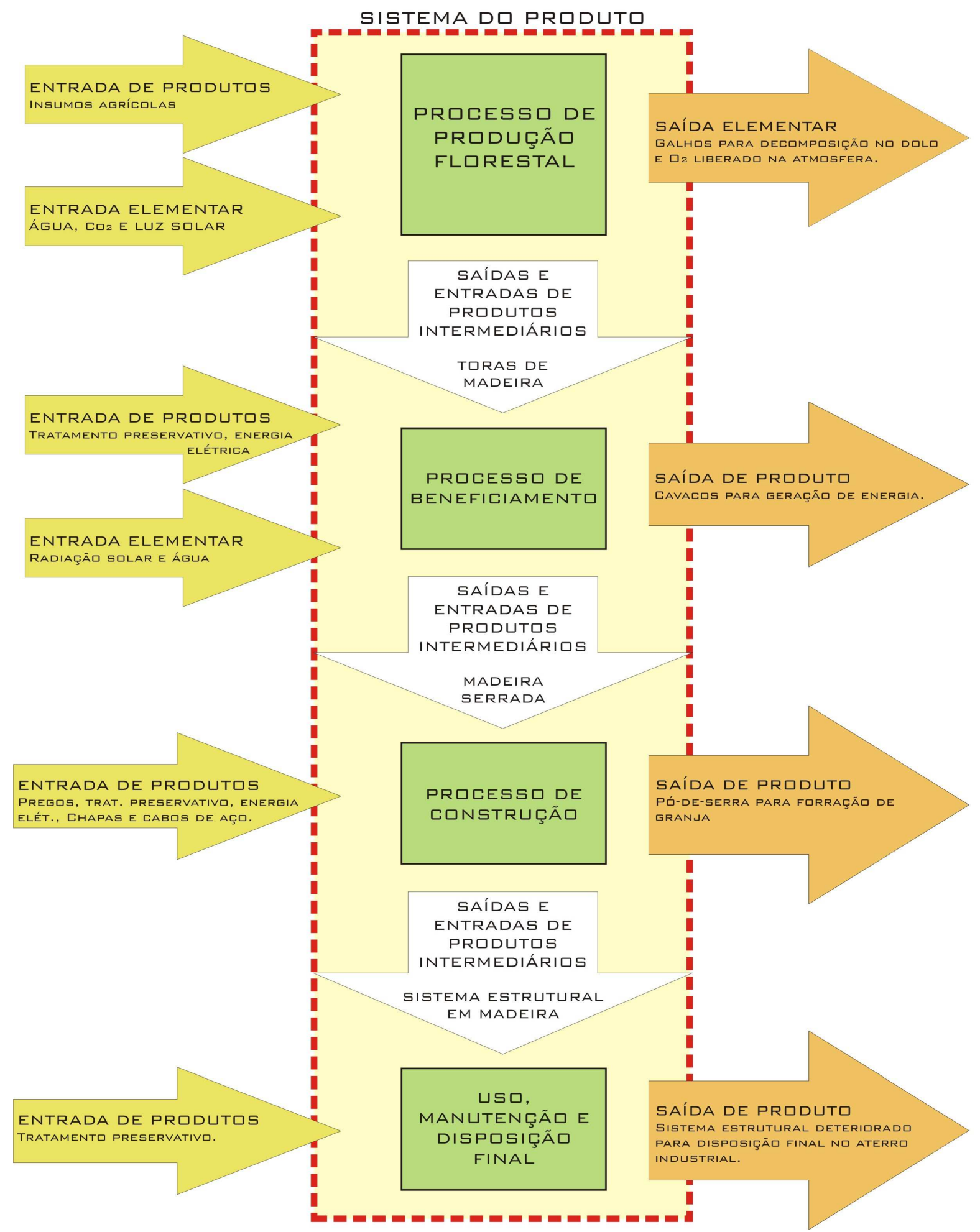

Figura 16: Exemplo de um conjunto de unidades de processos elementares e seus fluxos em um recorte de um sistema do produto.

Fonte: Autor 
Portanto, a partir do esclarecimento dos principais conceitos envolvidos e da delimitação da cadeia do produto a ser estudado, pode-se aplicar a estrutura do método de avaliação de ciclo de vida, que é normatizada pela ABNT, NBR ISO 14040, NBR ISO 14041, NBR ISO 14042, NBR ISO 14043, que regulamentam a aplicação do método de análise do ciclo de vida, dividida em quatro grandes etapas: I) Definição de objetivo e escopo; II) Análise de inventário; III) Avaliação de impacto e IV) Interpretação dos dados (ver figura 17).

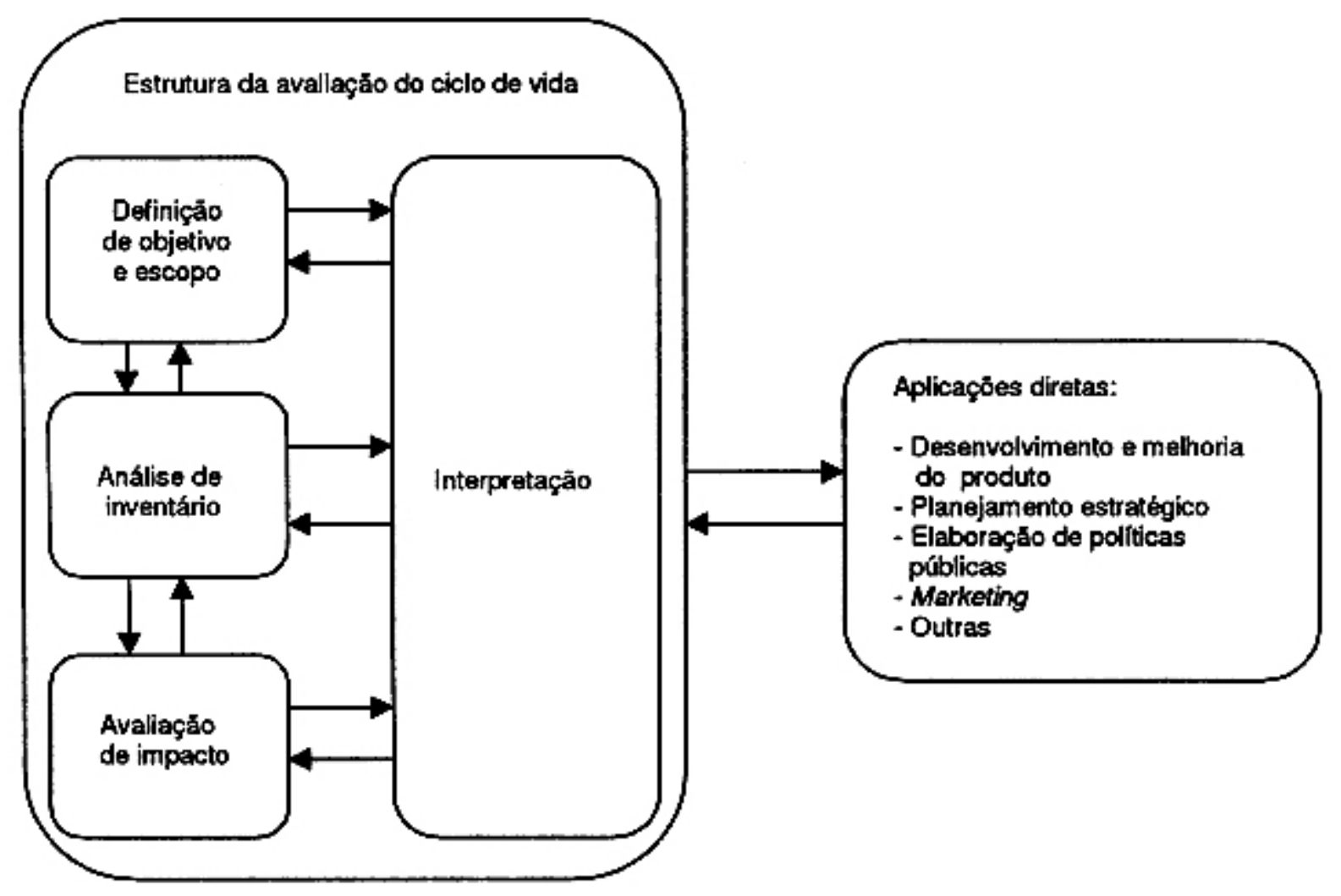

Figura 17: Estrutura das fases de uma avaliação de ciclo de vida. Fonte: ABNT (2001).

Cada etapa do método de avaliação do ciclo de vida será detalhada e revisada durante sua aplicação no sistema de produto da estrutura em Vigas Laminadas Pregadas. Porém, como foi verificado na literatura, trata-se de um método concentrado nos aspectos ambientais, pela sua própria definição, "[...] uma técnica para avaliar aspectos ambientais e impactos potenciais [...]" (ABNT, 2001), portanto no próximo item será feita a revisão do método visando uma análise pluridimensional. 


\subsubsection{Adaptação e ampliação da abrangência do método de avaliação do ciclo de vida para uma análise pluridimensional.}

Considerando-se o caráter unidimensional do método ACV, a partir dele serão feitas algumas considerações para se chegar à proposição de ferramentas capazes de fazer uma análise em diferentes dimensões, assim, serão utilizadas como base sua estrutura principal, apresentada na figura 17, e as etapas I, II, III, e IV, porém serão incluídas novas entradas e saídas de fluxos referentes às questões sociais, econômicas, políticas e culturais, baseadas em pesquisas que procuraram fazer um levantamento dos métodos já existentes e um balizamento das várias definições encontradas na literatura atual, em princípios e conceitos da sustentabilidade como aqueles analisados por Yuba (2005), Silva, S.(2000), entre outros. Procurou-se então, assim como na escolha do método de avaliação do ciclo de vida, buscar métodos para a análise das dimensões a serem incluídas utilizando os critérios levantados para escolha do método de análise da sustentabilidade descritos no item 1.4. Panorama dos métodos de análise da sustentabilidade e critérios para uma análise mais balanceada, mas agora não mais focados na questão ambiental, e sim nas questões social, econômica, política e cultural.

Um desses métodos já consolidados no Brasil são as normas para responsabilidade social, proposta pela ABNT 16001, que regulamentam os requisitos mínimos e os sistemas de gestão para que se atinja um maior grau de responsabilidade social. Segundo ABNT (2004), a responsabilidade social é a "relação ética e transparente da organização com todas as partes interessadas, visando o desenvolvimento sustentável", e acrescenta que, se adotada e implementada de forma sistêmica, pode contribuir para obtenção de resultados ótimos no campo social, resultando em um aumento da sustentabilidade, pois:

[...] o conceito de responsabilidade social é freqüentemente associado à concepção de desenvolvimento sustentável desenvolvido pela comissão Brutland e aceito pela conferencia da ONU - Rio de Janeiro 1992. Muitas das atividades associadas com a responsabilidade social refletem as três dimensões da sustentabilidade - econômica, ambiental e social - conceitos descritos como sustentabilidade.

O mesmo autor trata a sustentabilidade a partir do tripé - social, ambiental e econômico - porém define, baseando-se no GLOBAL REPORT INITIATIVE (2002) e de forma menos genérica que Sachs, a sustentabilidade social: 
A dimensão social da sustentabilidade refere-se aos impactos das organizações sobre os sistemas sociais (incluindo as questões política, cultural, espacial e espiritual entre outras) nos quais opera. [...] [...] Esta Norma utiliza as três dimensões da sustentabilidade como um de seus fundamentos.

Adotar-se-á a norma de responsabilidade social como base para a análise da sustentabilidade socioeconômica, pois poderá ser mais facilmente utilizada como base comparativa nacional, já que apresenta as variáveis do cenário brasileiro de forma mais contextualizada à realidade social local. O método ainda considera os diferentes atores envolvidos, como empresa, usuários, governo, consumidores, fornecedores e comunidade, além de ser balizado pelos critérios do GRI para elaboração de relatórios de sustentabilidade, iniciativa tida por SILVA, V. (2003), como a mais importante no campo de elaboração de indicadores de sustentabilidade para a escala da ação organizacional. O Global Reporting Initiative - GRI desenvolveu uma reporting framework de adoção voluntária para que corporações e organizações governamentais e não-governamentais, de qualquer setor econômico, pudessem relatar as dimensões econômica, social e ambiental de suas atividades, produtos e serviços, demonstrando assim, o seu comprometimento com o desenvolvimento sustentável através da publicação total ou parcial de um relatório de progresso de desempenho em sustentabilidade.

Desta maneira, o método da NBR 16001 foi escolhido para fazer a análise socioeconômica, pois:

- pode ser feito um levantamento de toda a cadeia através de entradas e saídas, se associado ao método de análise do ciclo de vida, formando uma base de dados nacional que estimularia o levantamento das condições do contexto brasileiro, repudiando a utilização de um método por imitação;

- faz um levantamento quantitativo e qualitativo socioeconômico das empresas, além de ser um sistema baseado em indicadores, capaz de simplificar uma análise complexa do sistema social, o que facilita a transferência e comparabilidade dos dados, ABNT (2004);

- identifica as deficiências sociais e econômicas ao longo de toda a cadeia (se associado ao $\mathrm{ACV}$, possibilitando verificar quais os processos causadores de impactos e sua relação com o resto da cadeia produtiva;

- é normalizado no Brasil pela Associação Brasileira de Normas Técnicas (ABNT), e possui um projeto de norma internacional em andamento pela International Standartization Organization (ISO) que será lançada em 2008 com o nome de ISO 26000, já tendo uma 
ampla legitimidade no cenário nacional, facilitando estudos comparativos entre os trabalhos já realizados;

Porém esse método também apresenta suas limitações:

- ao ser aplicado apenas no campo de ação organizacional, considerando as interações sociais dos agentes abordados nessa escala (construtores, usuários, comunidade de entorno e governo local), não sendo aplicado ao edifício ou a técnicas construtivas;

- na análise das relações entre dimensões e entre processos da cadeia produtiva;

- na análise de como cada questão repercute nas outras questões;

- na análise dos ganhos e perdas de sustentabilidade em uma dimensão;

- na análise dos ganhos e perdas de sustentabilidade entre as dimensões.

Segundo a ABNT 16001, o método para responsabilidade social deve fundamentar-se nos seguintes objetivos, metas e programas compatíveis com a responsabilidade social (que ainda podem ser complementados):

- Boas práticas de governança;

- Combate à pirataria, sonegação, fraude e corrupção;

- Práticas leais de concorrência;

- Direitos da criança e do adolescente, incluindo combate ao trabalho infantil;

- Direitos do trabalhador, incluindo o de livre associação, de negociação, de remuneração justa e benefícios básicos, bem como o combate ao trabalho forçado;

- Promoção da diversidade e combate à discriminação (por exemplo: cultural, de gênero, de raça/etnia, de idade, pessoa com deficiência);

- Compromisso com o desenvolvimento profissional;

- Promoção da saúde e segurança;

- Promoção de padrões sustentáveis de desenvolvimento, produção, distribuição e consumo, contemplando fornecedores, prestadores de serviço, entre outros;

- Proteção ao meio ambiente e aos direitos das gerações futuras; e

- $\quad$ Ações sociais de interesse público.

Para que as diretrizes acima sejam seguidas, a ABNT (2004) propõe a utilização de ferramentas para auxiliar na implementação e verificação de sistemas de responsabilidade social, e diz que: "Existem instituições de renome que propõem conceitos, práticas e indicadores que podem contribuir para o planejamento do sistema de gestão da responsabilidade social"; e coloca como 
referência as seguintes ferramentas de gestão: Indicadores Ethos, Guia de Elaboração do balanço social, Matriz de evidências de sustentabilidade, Banco de Práticas - Instituto Ethos de Empresas e Responsabilidade Social.

Serão utilizadas as ferramentas de análise da responsabilidade social empresarial criado pelo instituto ETHOS que já são empregadas por várias empresas brasileiras e possuem um banco de dados que facilita a análise comparativa entre seus resultados, levantando questões sociais e econômicas, dentro do padrão exigido pela norma ABNT 16001, sendo ainda acrescentadas algumas novas variáveis como as da dimensão econômica, produtividade, distribuição de riquezas e investimentos. $\mathrm{Na}$ fase de levantamento do inventário serão utilizados os métodos de "balanço social" e na fase de análise de impactos serão utilizados os "Indicadores Ethos", para médias e grandes empresas, e "Indicadores Ethos-SEBRAE", para pequenas e micro empresas.

Pretende-se aplicar esses métodos de responsabilidade social a todos os executores dos processos escolhidos na delimitação de fronteira do ciclo de vida (empresas, instituições ou outros agentes envolvidos), assim será possível analisar em que processos do sistema de produto haverá melhor ou pior desempenho social.

O método de "balanço social" do Instituto Ethos baseia-se em um grande questionário quantitativo e qualitativo de análise da empresa, que segundo Custodio; Moya (2007) pode ser dividido nas seguintes etapas: 1- Definição dos facilitadores, 2- Capacitação e conscientização dos facilitadores sobre os indicadores, 3- Preenchimento dos indicadores, 4- Verificação dos fatores críticos e consolidação final dos dados e 5- Obtenção do relatório final.

As dimensões política e cultural não possuem métodos consagrados de avaliação, portanto as variáveis dessas dimensões foram formuladas a partir dos princípios e conceitos da sustentabilidade levantados por Yuba (2005), Silva, S (2000) e Sachs (1993) e serão acrescentadas dentro dos métodos existentes como entradas e saídas através de levantamentos quantitativos e qualitativos. Assim como as questões sociais, essas variáveis poderão futuramente ser relacionadas a indicadores capazes de ponderar e transformar as informações em uma base de fácil comparação e divulgação.

A adição das novas classes de variáveis (cultural, política, social e econômica) permitirão então criar uma base comparativa que mostrará a situação de cada dimensão em um determinado processo elementar da cadeia do produto, além de permitir a análise dos ganhos e perdas 
concretizados em uma determinada dimensão ao longo da cadeia, graças à associação do método de análise do ciclo de vida.

Isso faz com que a adição dos métodos empregados supere algumas limitações que os mesmos possuíam individualmente:

- as relações entre dimensões e entre processos da cadeia produtiva;

- como cada questão repercute nas outras questões;

- os ganhos e perdas de sustentabilidade em uma dimensão;

- os ganhos e perdas de sustentabilidade entre as dimensões.

Assim fica como principal limitante do método seu campo de ação, que se restringirá ao do edifício e organizacional, segundo o esquema da figura 4, permitindo redefinir as etapas do método que agora será nomeado de Avaliação Pluridimensional do Ciclo de Vida - APCV.

\subsection{Aplicação do método de APCV - Avaliação Pluridimensional do Ciclo de Vida na cadeia do sistema estrutural de cobertura em VLP.}

Para aplicação do método no objeto de estudo, partir-se-á a estrutura do método de avaliação do ciclo de vida, porém, além das etapas e da revisão do método já apresentadas, deve-se ainda definir e revisar uma série de sub-etapas que são essenciais para uma análise do ciclo de vida com consistência e confiabilidade. Para um bom entendimento do conjunto de etapas e sub-etapas do método foi elaborada a figura 18, que mostra essas sub divisões e em que capítulos essas serão abordadas. 


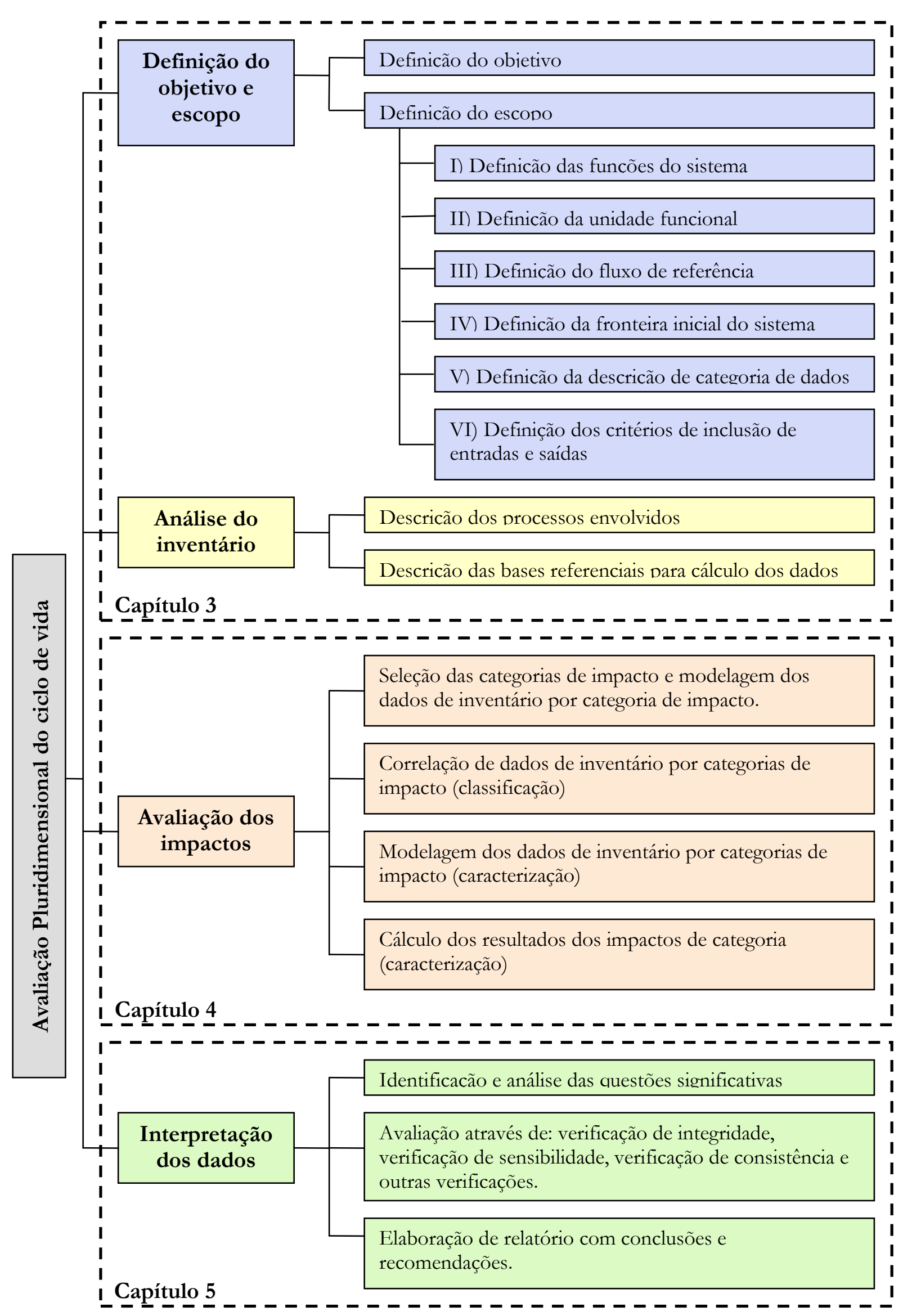

Figura 18: Estrutura geral do método APCV

Fonte: autor 


\subsection{Definição do objetivo e escopo do objeto de estudo.}

Nesse item será detalhada cada sub-etapa da definição do objetivo e escopo, elucidando as definições convencionais dadas pelas normas, adaptando o método ACV, para que se aproxime de uma análise pluridimensional, e por fim aplicando o método no objeto de estudo, que é a cadeia do sistema estrutural em VLP.

\subsubsection{Definição do objetivo do estudo.}

O objetivo de um estudo convencional de avaliação do ciclo de vida (ACV) deve declarar inequivocamente a aplicação pretendida, as razões para conduzir o estudo e o público alvo (como o estudo está sendo realizado, quais serão as aplicações dos resultados obtidos e para quem se pretende transmitir os resultados).

Deve-se ressaltar que para se fazer uma análise da sustentabilidade para além da questão ambiental, é necessário acrescentar quais dimensões serão abordadas, colocando como objetivo uma análise que possa avaliar as relações entre dimensões e entre processos da cadeia produtiva, como cada questão repercute nas outras questões e os ganhos e perdas de sustentabilidade em uma dimensão e entre as dimensões.

Assim, o objetivo principal da avaliação pluridimensional do ciclo de vida nesse objeto de estudo é levantar e analisar todo ciclo de vida do sistema estrutural de cobertura em madeira de Pinus de terceira qualidade utilizado na experiência do assentamento rural Pirituba II, em suas múltiplas dimensões: ambiental, cultural, econômica, política e social, relacionando os ganhos e perdas de sustentabilidade ao longo dos processos e entre suas dimensões.

O trabalho procura cobrir uma lacuna do conhecimento nos estudos de sistemas construtivos mais sustentáveis, procurando analisar o ciclo de vida do sistema estrutural proposto, viabilizando assim uma futura análise pluridimensional da sustentabilidade entre diferentes sistemas construtivos, para então propor uma melhor forma da construção civil atuar na realidade.

\subsubsection{Definição do escopo do objeto de estudo.}

De acordo com a norma NBR 14040, escopo do estudo pode ser tratado genericamente como a amplitude que o trabalho vai abordar, e pode ser dividido em seis categorias: I) funções do sistema do produto, II) unidade funcional, III) fluxo de referência, IV) fronteiras do sistema inicial, V) descrição das categorias de dados e VI) critérios de inclusão de entradas e saídas. 
Detalhar-se-á cada categoria procurando dar sua definição segundo a norma, fazendo sua revisão para que se atinja o objetivo pretendido e aplicando-as ao objeto de estudo.

\section{I) As funções do sistema.}

As funções do sistema do produto são o fim para que se destina tal produto, ou de forma simplificada "para que serve". Como exemplo tem-se que o sistema estrutural de cobertura se destina a suportar eficientemente a carga do sistema de cobertura, proporcionando segurança e estabilidade.

Para uma análise de sustentabilidade de habitações é importante ressaltar não somente para que fim é usado determinado produto, mas se ele consegue atingir aquele fim com um nível de desempenho satisfatório, pois o desempenho da edificação está diretamente ligado ao usuário e sua qualidade de vida. Segundo Yuba (2005) a abordagem normalmente feita pelos métodos de avaliação de sustentabilidade nessa etapa é focada na avaliação de desempenho da edificação (estrutural, durabilidade, conforto ambiental) muitas vezes feitas através de avaliações pósocupação, porém nesse trabalho será utilizada a norma de "Avaliação do Desempenho das Habitações de até 5 Pavimentos", que avalia o desempenho das habitações ainda na fase de projeto, e cujo foco "[...] está nas exigências dos usuários para o edifício habitacional e seus sistemas, quanto ao seu comportamento em uso [...]", sempre considerando o contexto brasileiro (ABNT, 2008). Segundo a referida norma as habitações devem atender os níveis mínimos de qualidade dentro dos seguintes itens:

- Segurança estrutural

- Segurança contra incêndio

- Segurança no uso e na operação

- Estanqueidade

- Conforto térmico

- Conforto acústico

- Conforto lumínico

- Durabilidade e manutenabilidade

- Saúde, higiene e qualidade do ar

- Funcionalidade e acessibilidade

- Conforto táctil e antropodinâmico

- Adequação ambiental 
A norma também define que a função de um sistema estrutural de cobertura é "apresentar um nível satisfatório de segurança contra a ruína, e não apresentar avarias ou deformações excessivas que prejudiquem a funcionalidade do sistema de cobertura ou dos sistemas contíguos, considerando-se as combinações de ações passíveis de ocorrerem durante a vida útil do edifício habitacional", e propõe que o mesmo deve atingir o nível de desempenho satisfatório nos seguintes requisitos:

- Segurança estrutural

- Segurança contra incêndio

- Durabilidade e manutenabilidade

- Adequação ambiental

Ainda de acordo com a ABNT (2008), os sistemas estruturais de cobertura devem atender especificamente aos seguintes requisitos de desempenho:

- de resistência e deformabilidade

- de solicitações de montagem ou manutenção

- de solicitações dinâmicas em sistemas de coberturas e em coberturas-terraço acessíveis aos usuários

- para solicitações em forros

- para a ação do granizo e outras cargas acidentais em telhados

Esta mesma norma apresenta um quadro de vida útil prevista para cada parte da edificação, classificando em 3 níveis de desempenho: mínimo, intermediário e superior, (ver Quadro 6).

A partir destas definições de função e de desempenho encontradas na norma, para a presente análise, considerou-se os seguintes requisitos:

- a segurança estrutural (e todas as solicitações de esforços e deformabilidade) foi verificada de acordo com a norma NBR 7190 de estruturas de madeira, sendo necessários ensaios em laboratório para adaptar a classe de madeira (de terceira qualidade) que não está normalizada. O sistema atende a todos os seus requisitos, que podem ser verificados no cálculo estrutural, Anexo IV (fornecido em CD);

- a segurança contra incêndio não foi verificada, fica aqui o registro como lacuna de conhecimento para futuros trabalhos; 
- a durabilidade e manutenabilidade foram verificadas e atendem aos requisitos da norma que exigem: "Os sistemas, elementos e componentes que compõem o edifício habitacional devem apresentar durabilidade compatível com a vida útil esperada, especificada em projeto de forma a atender à tabela E.1 indicada no anexo E", considerando o sistema estrutural de cobertura dentro do item "fundação, estrutura principal, estruturas periféricas, contenções e arrimos" ( a primeira coluna do Quadro 1) e com previsão de durabilidade igual ou superior a 50 anos (a partir das recomendações de manutenção do fabricante do tratamento preservativo), adota-se o desempenho no patamar superior, indicado pela letra "S"; ver quadro 6.

- a adequação ambiental será verificada no capítulo 5, a partir da aplicação do método de análise do ciclo de vida, que levanta os impactos ambientais gerados pelo sistema.

Quadro 6 - Vida útil de projeto e níveis de desempenho $(\mathrm{M}=$ mínimo, $\mathrm{I}=$ intermediário, $\mathrm{S}=$ superior $)$.

\begin{tabular}{|c|c|c|c|}
\hline \multirow{2}{*}{ Sistemas, elementos ou componentes } & \multicolumn{3}{|c|}{ Anos } \\
\hline & M & I & $\mathrm{S}$ \\
\hline $\begin{array}{l}\text { Fundações, estrutura principal, estruturas periféricas, } \\
\text { contenções e arrimos }\end{array}$ & $\geq 25$ & $\geq 35$ & $\geq 50$ \\
\hline Sistemas de cobertura & $\geq 10$ & $\geq 15$ & $\geq 20$ \\
\hline $\begin{array}{l}\text { Paredes de vedação, estrutura das escadarias internas } \\
\text { ou externas, guarda-corpos, muros de divisa }\end{array}$ & $\geq 15$ & $\geq 20$ & $\geq 30$ \\
\hline Equipamentos & $\geq 8$ & $\geq 10$ & $\geq 12$ \\
\hline $\begin{array}{l}\text { Sistemas de proteção contra descargas atmosféricas } \\
\text { Sistemas de combate a incêndio } \\
\text { Sistemas de pressurização das escadas } \\
\text { Sistemas de segurança patrimonial }\end{array}$ & $\geq 8$ & $\geq 10$ & $\geq 12$ \\
\hline Porta corta-fogo & $\geq 8$ & $\geq 10$ & $\geq 12$ \\
\hline $\begin{array}{l}\text { Sistemas hidrossanitários e instalações de gás: } \\
\text { colunas de água fria e colunas de água quente; } \\
\text { tubos de queda de esgoto; } \\
\text { colunas de gás; coletores, ramais } \\
\text { Aparelhos e metais sanitários: } \\
\text { louças, caixas de descarga, bancadas,sifões, ligações } \\
\text { flexíveis, válvulas, registros, ralos e tanques }\end{array}$ & $\geq 10$ & $\geq 15$ & $\geq 20$ \\
\hline Sistemas de impermeabilização & $\geq 5$ & $\geq 8$ & $\geq 10$ \\
\hline Esquadrias de madeira, de ferro, de alumínio e de PVC & $\geq 8$ & $\geq 10$ & $\geq 12$ \\
\hline Fechaduras e ferragens & $\geq 6$ & $\geq 8$ & $\geq 10$ \\
\hline \begin{tabular}{|l|} 
Revestimentos de paredes, pisos e tetos internos e \\
externos
\end{tabular} & $\geq 10$ & $\geq 15$ & $\geq 20$ \\
\hline $\begin{array}{l}\text { Pisos de madeira: } \\
\text { tacos, assoalhos e decks } \\
\text { Cimentados, piso acabado em concreto e contrapiso }\end{array}$ & $\geq 10$ & $\geq 15$ & $\geq 20$ \\
\hline $\begin{array}{l}\text { Revestimentos especiais: } \\
\text { fórmica, plásticos, têxteis, pisos elevados, materiais } \\
\text { compostos de alumínio) }\end{array}$ & $\geq 10$ & $\geq 15$ & $\geq 20$ \\
\hline Forros de gesso e madeira & $\geq 10$ & $\geq 15$ & $\geq 20$ \\
\hline Pintura interna e externa) & $\geq 3$ & $\geq 4$ & $\geq 5$ \\
\hline Selantes, componentes de juntas e rejuntamentos & $\geq 3$ & $\geq 4$ & $\geq 5$ \\
\hline Vidros & $\geq 8$ & $\geq 10$ & $\geq 12$ \\
\hline
\end{tabular}

Fonte: ABNT (2002). 


\section{II) A unidade funcional.}

De forma simplificada pode-se dizer que a unidade funcional é a base de referência de um sistema de produto que permite estabelecer comparações entre seus dados de entrada e saída e os de outros sistemas. Por exemplo, se a unidade funcional de um sistema de produto for definida como sendo um metro quadrado de sistema estrutural de cobertura em madeira, pode-se ter $10 \mathrm{Kwh}$ de entrada de energia elétrica, que pode ser comparada aos $80 \mathrm{kwh}$ de entrada de energia elétrica na produção de um metro quadrado de sistema estrutural de cobertura em alumínio (unidade funcional de outro sistema de produto).

À unidade funcional serão acrescentadas as características temporais e espaciais da sustentabilidade, dois importantes pontos levantados na literatura e analisados por Yuba (2005) e Silva, S. (2000) contrapondo a limitação do método ACV colocada pela ABNT (2001) no que se refere à "falta de dimensões espaciais e temporais dos dados do inventário usados para avaliar os impactos". Assim, será especificado o local para onde se destina a unidade funcional e qual a previsão de durabilidade, de determinado edifício ou sistema construtivo, a partir do quadro 6 , de vida útil do projeto e seu desempenho, que alterará os impactos de manutenção, renovação do material e reciclagem, durante os processos elementares de uso e manutenção.

A unidade funcional no caso deste objeto de estudo será $\mathrm{o}^{3}$ do sistema estrutural proposto montado no Assentamento Pirituba II durante 50 anos. Essa unidade funcional atende a todos os requisitos colocados anteriormente para estabelecimento de uma medida que permitirá a comparação entre diferentes sistemas de produto, dentro das cinco dimensões da sustentabilidade propostas. A unidade metro cúbico foi tomada devido à grande variabilidade de projetos estruturais (dependendo do projeto estrutural se utiliza mais ou menos volume de materiais, como a diferença entre aço e concreto armado) e tipo de edificações (construções com utilizações diferentes como um galpão e uma habitação com a mesma área construída terão um volume maior ou menor de materiais utilizados). Também foram acrescentados o fator espacial (pois o sistema do produto no processo de construção em uma metrópole e em um assentamento rural possui diferenças) e a base temporal, considerada a partir do quadro 6 , de vida útil de projeto e níveis de desempenho, onde foi adotada a vida útil de um sistema estrutural a partir do desempenho superior. 


\section{III) O fluxo de referência.}

Fluxo de referência é a quantidade de unidades funcionais necessárias para cumprir uma determinada função (ex.: quantidade de $\mathrm{m}^{2}$ de sistema estrutural de madeira instalado em obra necessário para cobrir uma habitação de $70 \mathrm{~m}^{2}$ ).

No objeto de estudo o fluxo de referência será baseado no volume de metros cúbicos de sistema estrutural necessário para cobrir uma habitação social rural de $75,8 \mathrm{~m}^{2}$, com área coberta de $106,00 \mathrm{~m}^{2}$. O quadro 7 apresenta o quantitativo de componentes pré-fabricados e os respectivos volumes, ao final, tem-se a soma de $2,86 \mathrm{~m}^{3}$, volume necessário para cobrir uma casa de $75,8 \mathrm{~m}^{2}$, ou seja, o fluxo de referência é $\mathbf{2 , 8 6}$ unidades funcionais para o objeto em estudo.

Quadro 7: Quantitativo de componentes e respectivo volume do sistema estrutural pré-fabricada para uma habitação.

\begin{tabular}{|l|c|c|c|}
\hline \multicolumn{3}{|c|}{ Modelo 3QBF (3 quartos banheiro fora) } \\
\hline \multicolumn{2}{|c|}{ Materiais } & \multicolumn{2}{c|}{ Volumes } \\
\hline Componentes & $\begin{array}{c}\text { Quantidade para } \\
\text { uma casa }\end{array}$ & Unitário $\left(\mathrm{m}^{3}\right)$ & Total $\left(\mathrm{m}^{3}\right)$ \\
\hline VLP composta & 2 & 0,052 & 0,105 \\
\hline VLP de 2,70m & 36 & 0,018 & 0,653 \\
\hline VLP de 3,40m & 72 & 0,022 & 1,645 \\
\hline VLP de varanda & 3 & 0,034 & 0,102 \\
\hline Beiral com mão-francesa & 5 & 0,008 & 0,044 \\
\hline Berço 1,6x11cm & 28 & 0,003 & 0,088 \\
\hline Emenda de VLP* & 72 & 0,001 & 0,096 \\
\hline Ripa 1,6x5cm & 12 & 0,001 & 0,017 \\
\hline Espaçador de Eucalipto & 123 & 0,0005 & 0,067 \\
\hline Chapuz de Eucalipto & 164 & 0,0002 & 0,039 \\
\hline Total & & & 2,86 \\
\hline
\end{tabular}

Fonte: Valle, (2007).

\section{IV) Fronteira do sistema inicial.}

A fronteira do sistema inicial define quais processos deverão ser incluídos no sistema de produto a ser modelado, que de forma simplificada pode-se dizer que é a escolha de quais etapas de produção de um produto serão analisadas, desde a retirada da matéria prima até a disposição final, ou se algumas etapas serão suprimidas por alguma razão. De forma ideal a fronteira do sistema teria como entradas apenas fluxos elementares (retirada de matérias primas da natureza), ou seja, materiais não transformados pelo homem. É importante salientar que a norma coloca que "na maioria dos casos não haverá tempo, dados ou recursos financeiros suficientes para conduzir um estudo tão abrangente", e justamente devido a essa abrangência deve-se decidir 
quais processos elementares serão estudados e quais não serão relevantes para obtenção do objetivo proposto, desde que quaisquer decisões de omitir estágios de ciclo de vida, processos ou entradas e saídas sejam claramente declaradas e justificadas. Para facilitar o entendimento do sistema de produto é recomendado o uso de um fluxograma das etapas que apresente os processos elementares e suas inter-relações.

Deve-se atentar para a fronteira do sistema inicial em um estudo pluridimensional, pois a complexidade e abrangência do estudo são ainda maiores que um estudo simples de ACV, e pode-se exigir uma fronteira menor para viabilizar o estudo.

No objeto de estudo em questão a delimitação do processo é muito importante para tornar a análise viável dentro do tempo da pesquisa de mestrado proposta e dos recursos financeiros disponíveis. Existe uma grande quantidade de cadeias produtivas envolvidas no processo de produção e construção do sistema de cobertura em madeira de Pinus, e elas podem estar relacionadas diretamente com o processo de produção dos componentes (como no caso da cadeia de produção dos pregos utilizados diretamente nos componentes) ou indiretamente através da relação com outros processos (como no caso da cadeia de produção de adubos e defensivos agrícolas, utilizados no processo de produção florestal que gerará a matéria-prima para os componentes de cobertura). As relações também podem se dar ao longo de todo um processo (utiliza-se energia elétrica em todas as etapas do processo de beneficiamento) ou em apenas uma etapa (utiliza-se energia apenas na etapa de chumbamento no processo de montagem dos componentes pré-fabricados no canteiro). Segundo ABNT (2004) é recomendável a presença de alguns processos elementares e fluxos dentro da fronteira do sistema, como:

- entradas e saídas na seqüência principal de fabricação / processamento;

- distribuição / transporte;

- uso e manutenção dos produtos;

- disposição dos resíduos de processo e de produtos;

- recuperação de produtos usados;

- fabricação de materiais auxiliares;

- produção / uso de combustíveis, eletricidade e calor;

- operações adicionais como iluminação e aquecimento.

No estudo da cadeia de produção das vigas laminadas pregadas os dois materiais básicos são a madeira de Pinus e os pregos, e o principal material a ser analisado será a madeira de Pinus de terceira qualidade, por representar 59\% do custo total e $92 \%$ da massa dos materiais empregados, 
ou seja, representa o maior consumo de recursos naturais e terá o maior valor despendido. Os gráficos das figuras 19 e 20 mostram a porcentagem de custo de cada matéria prima e a porcentagem da massa de cada material empregado, respectivamente Os dados para elaboração dos gráficos a seguir estão nas planilhas de coleta de dados no anexo I.

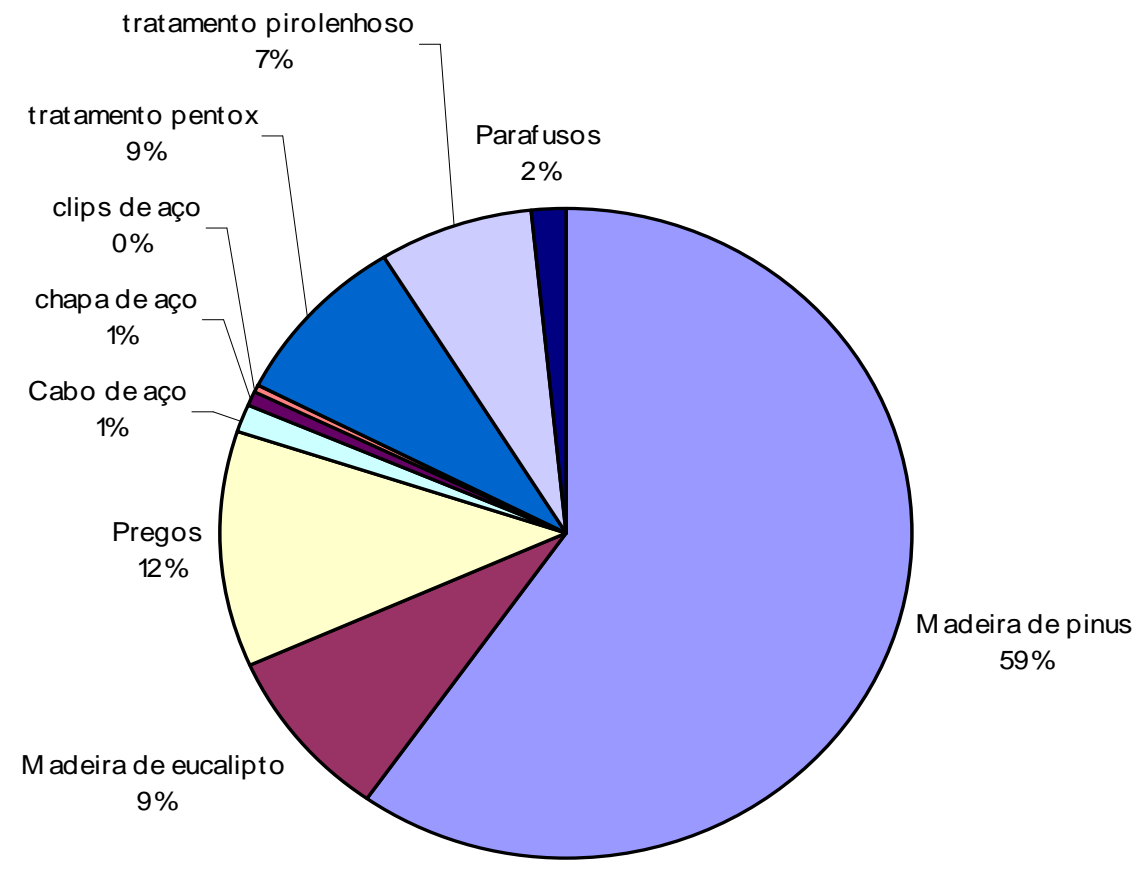

Figura 19: Porcentagem de custo de cada material dentro do sistema de cobertura. Fonte: Autor

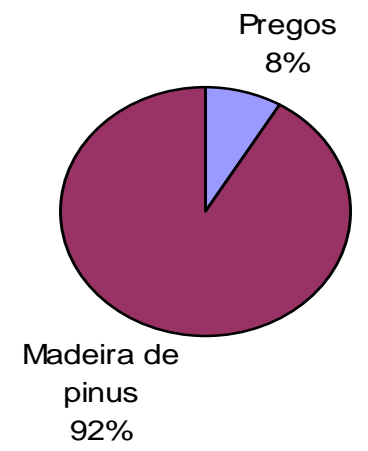

Figura 20: Porcentagem de massa de cada material dentro da estrutura. Fonte: Autor

A partir dos dados observados anteriormente, o principal processo a ser considerado será o da matéria prima "madeira de Pinus de terceira qualidade" e seu processo de produção. Os materiais dos processos secundários, como os pregos e a madeira de Eucalipto, serão estudados na forma 
de entradas (inputs) para cada etapa, podendo-se assim analisar o seus impactos dentro da cadeia produtiva principal, sem no entanto detalhar e analisar cada etapa de seu processo. Yuba (2005) caracteriza a cadeia de produção em habitação em madeira pela seqüência dos seguintes processos elementares: produção florestal, beneficiamento da madeira e construção; além das operações de uso, manutenção e disposição final. As figuras 21 e 22 representam esquematicamente os processos envolvidos na cadeia de produção do sistema de cobertura e a delimitação feita para os processos que apresentam maior influência.

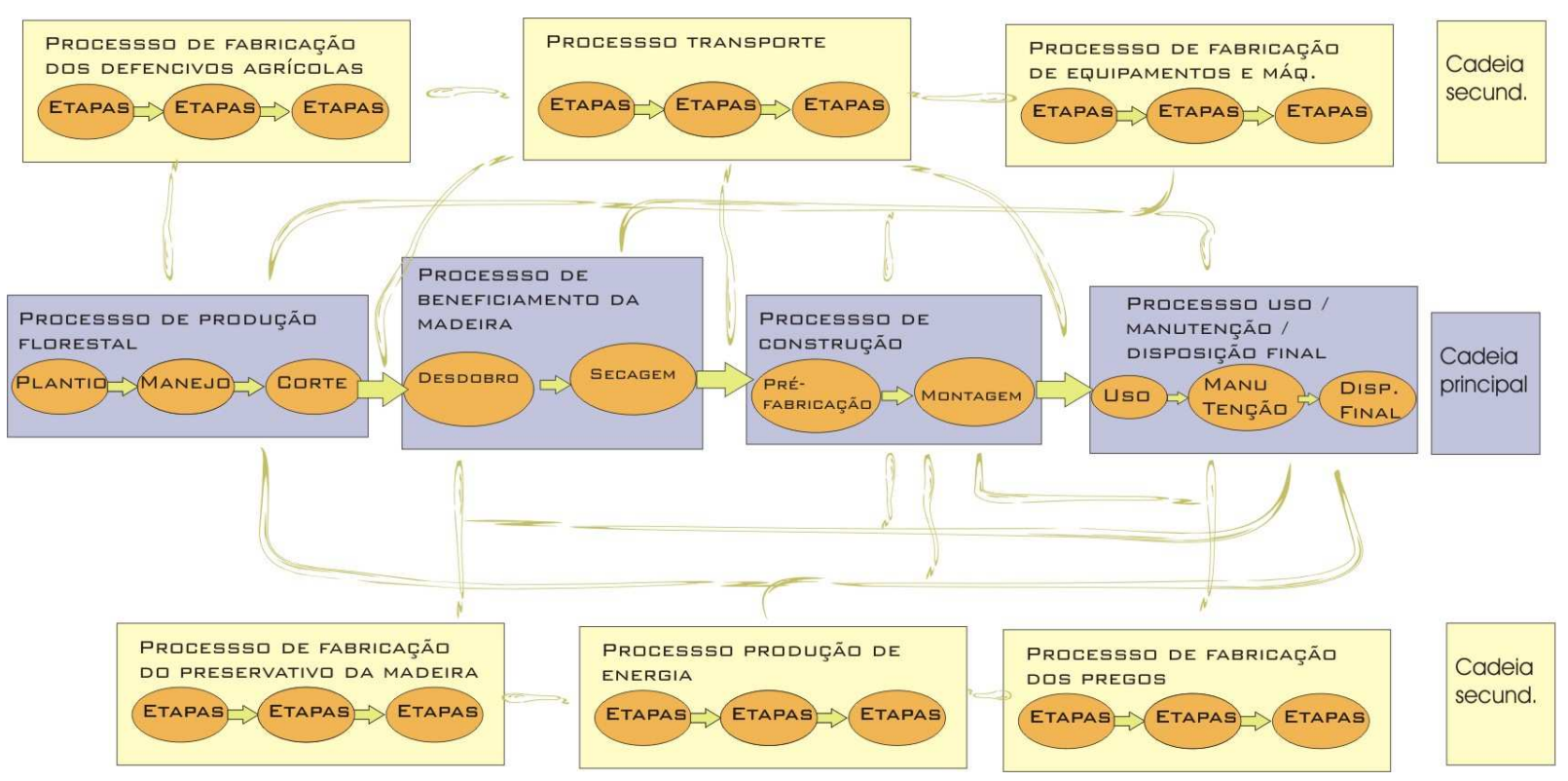

Figura 21: Esquema dos processos envolvidos na cadeia de produção do sistema de cobertura em Pinus. Fonte: Autor

Assim, a partir dos critérios colocados pela ABNT (2004) e pelo estudo já colocado acima, foi delimitada a fronteira do sistema na cadeia principal que considera os quatro processos: 1) Produção Florestal: 2) Beneficiamento da Madeira; 3) Construção; e 4) Uso, Manutenção e Disposição Final, (ver figura 22). 


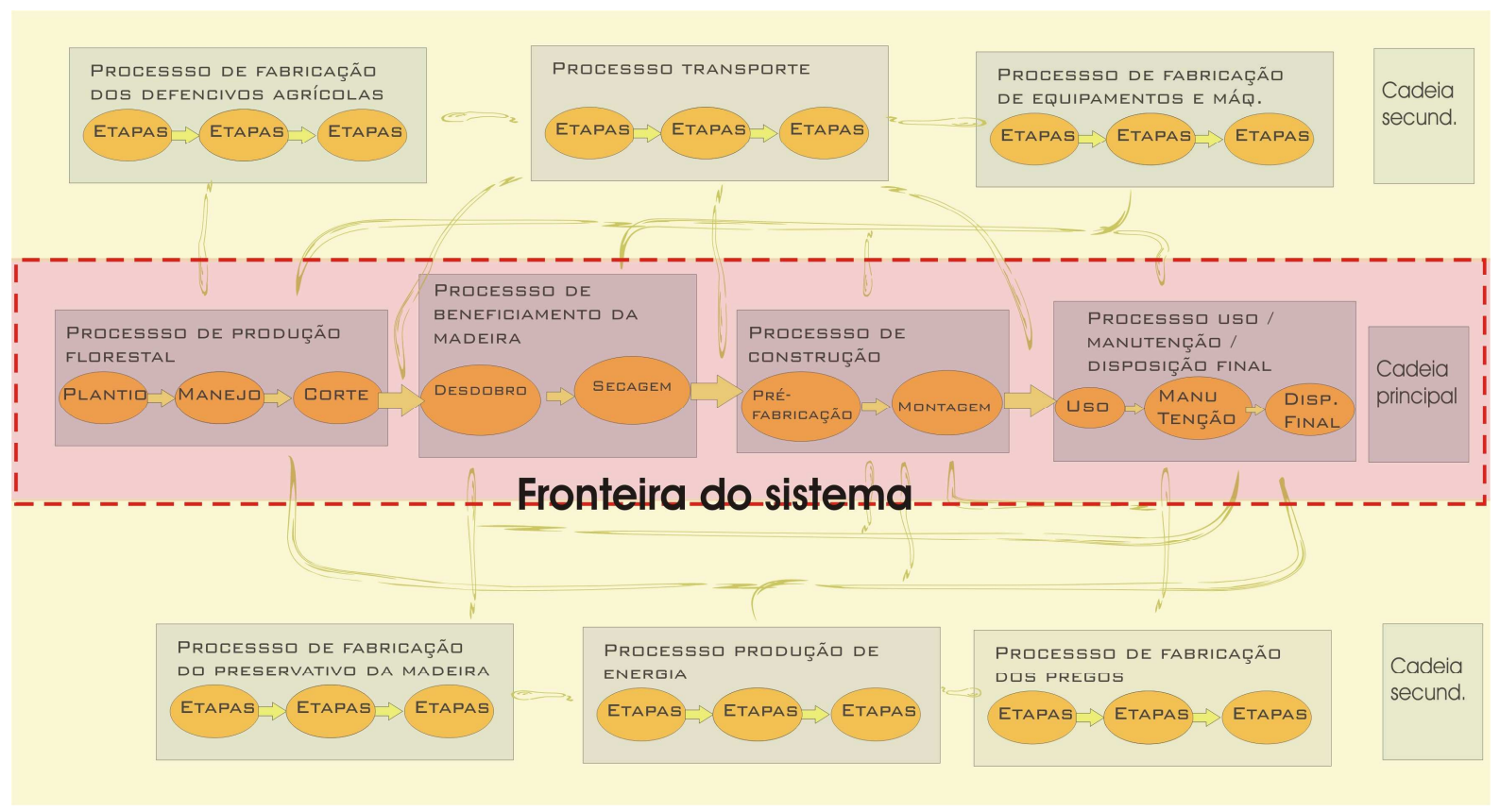

Figura 22: Delimitação dos processos de maior influência dentro da cadeia de produção do sistema estrutural de coberturas em vigas laminadas pregadas.

Fonte: Autor

Os processos elementares escolhidos serão divididos em operações, de onde serão coletados os dados de entradas (inputs) e saídas (outputs). No caso de operações complexas será utilizada a decomposição em etapas, que também poderão ser decompostas em sub-etapas e essas decompostas quantas vezes forem necessárias para a apreensão do processo (ABNT, 2004). No entanto, também é necessário estabelecer um limite para o detalhamento do processo, para que não se crie uma quantidade inviável de variáveis a serem coletadas que possam inviabilizar a pesquisa por falta de recursos financeiros, indisponibilidade de dados ou tempo. Além disso, é necessário verificar qual a relevância do detalhamento desse processo para não se criar variáveis que não influenciariam no objetivo proposto e na análise do processo (ABNT, 2004). Na decomposição da operação pré-fabricação dos componentes pode-se gerar um número grande de etapas e sub-etapas que, pelo seu nível de detalhamento, não trariam benefícios a essa pesquisa devido ao objetivo que aqui foi colocado. Porém essa subdivisão pode ser útil para pesquisas como as que procuram o aperfeiçoamento de um determinado produto ou a verificação de gargalos de produção.

A experiência de produção de vigas laminadas pregadas foi estudada pelo grupo de pesquisa Habis no RELATÓRIO TRIMESTRAL DO PROJETO DE PESQUISA (2005), que faz uma grande decomposição do processo de capacitação da pré-fabricação onde os autores fazem um estudo sobre o processo elementar apresentado, verificando suas dificuldades e gargalos, e posteriormente propondo uma mudança na forma como esse processo é feito. Nesse caso a 
decomposição em sub-etapas detalhadas foi imprescindível, pois o estudo tinha como objetivo a melhoria na forma de produção das vigas laminadas pregadas, porém, como o esquema da figura 23 mostra através de um exemplo de classificação das subdivisões do processo elementar em etapas e sub-etapas, essas últimas não possuem nenhum impacto quanto às dimensões estudadas nesse trabalho e seu objetivo. Mesmo as entradas e saídas que surgirão dessas pequenas subetapas estarão expressas nas entradas e saídas finais de cada etapa, como a soma de homens/horas/metro cúbico produzido em cada sub-etapa ou mesmo as questões relativas à participação das famílias durante cada sub-etapa do processo produtivo.

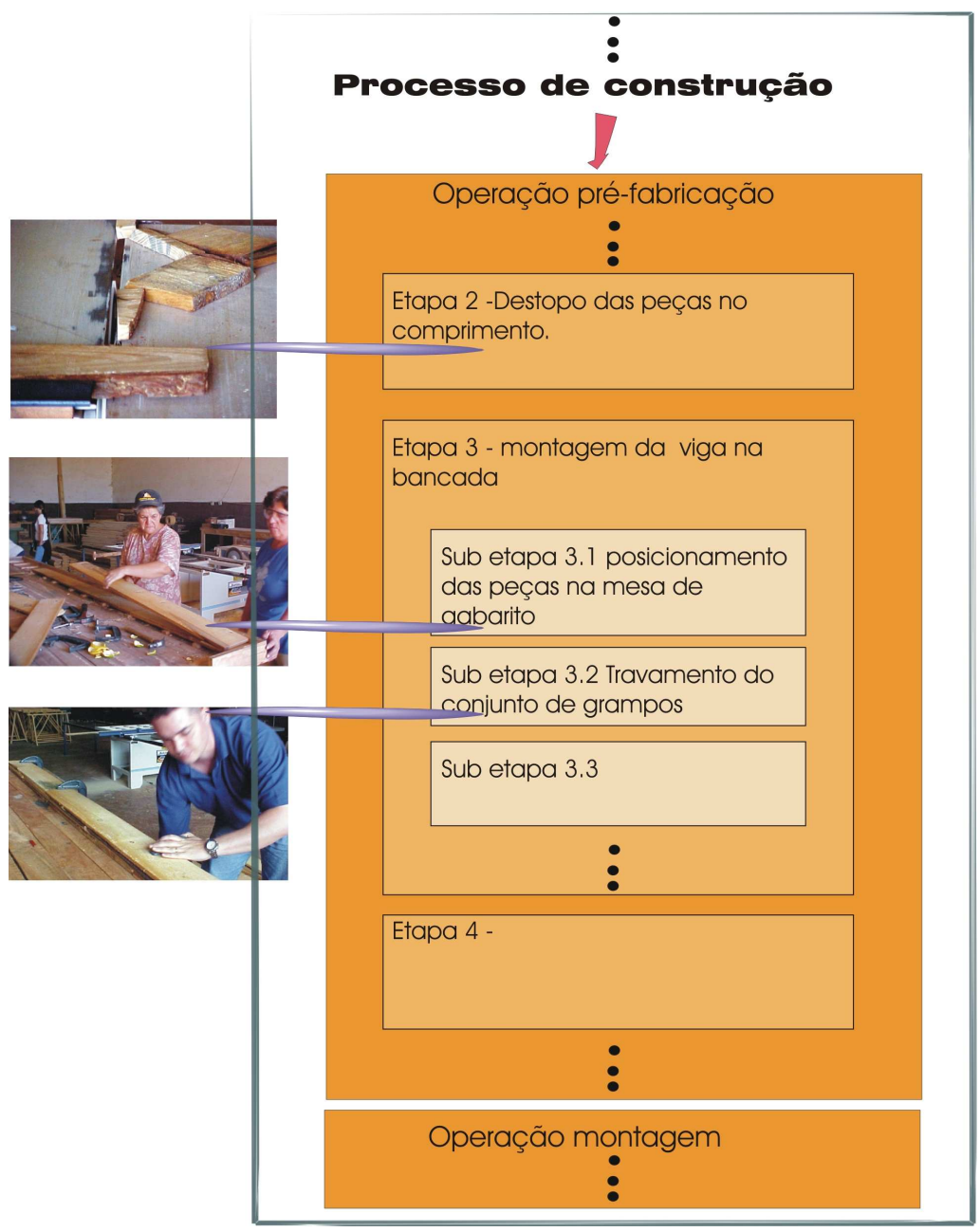

Figura 23: Exemplo de divisão das etapas em sub-etapas.

Fonte: Autor.

Após a definição da abrangência dos estudos nos níveis macro (quais os processos envolvidos que serão estudados) e micro (quais as etapas e sub-etapas que serão abordadas), chegou-se à cadeia a ser estudada (representada na figura 24) dentro do ciclo de vida. 


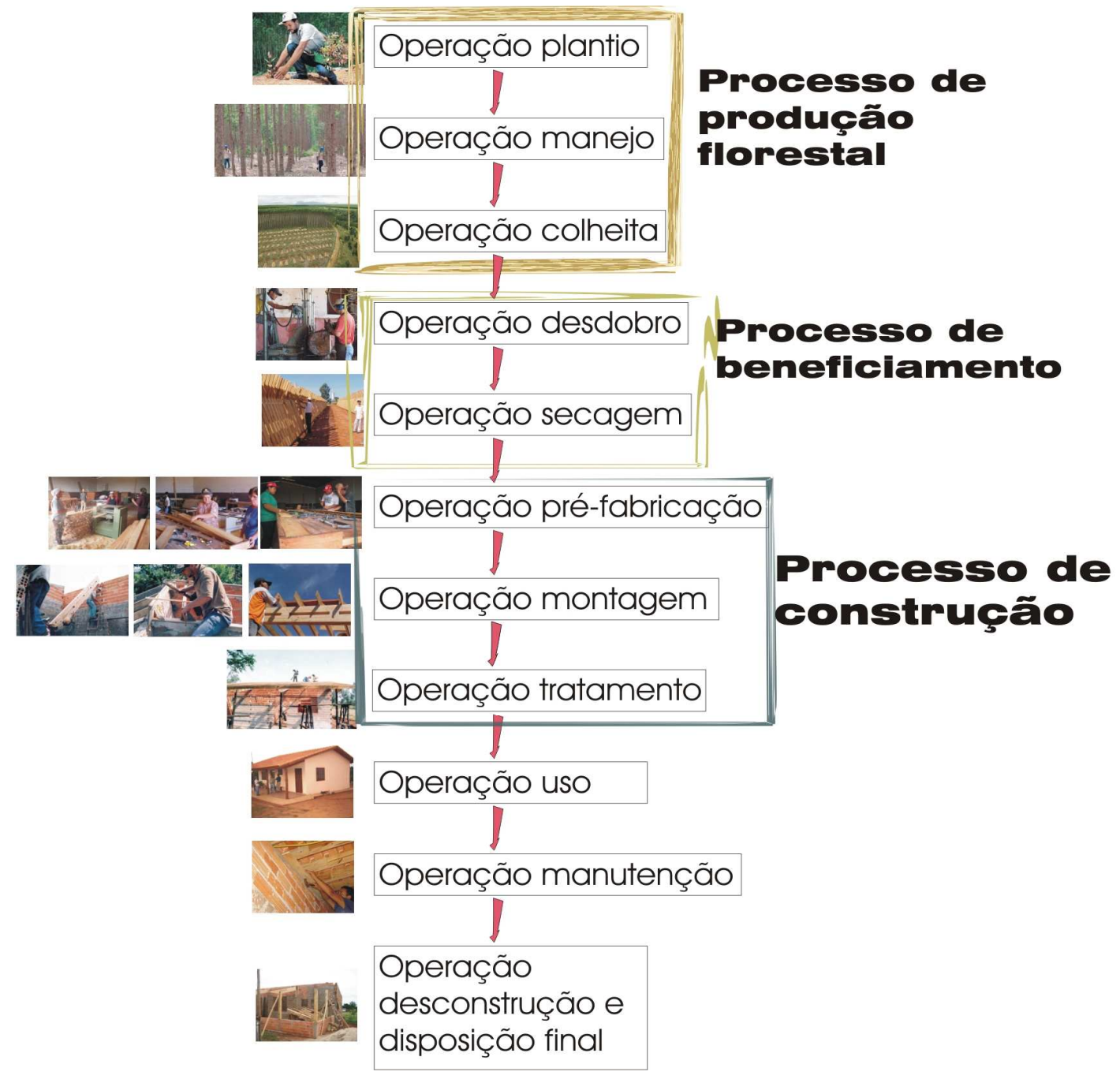

Figura 24: Ciclo de vida da estrutura de cobertura em vigas laminadas pregadas. Fonte: Adaptado de YUBA (2005).

\section{V) Descrição de categorias dos dados.}

A descrição das categorias dos dados são as referências de como os dados são obtidos, podendo ser coletados no local, calculados a partir de literatura, etc. No objeto de estudo os dados serão obtidos a partir das fontes de evidência da observação direta e registros em gaveta dos assessores do processo de construção, além de entrevistas e revisão bibliográfica para os dados não levantados no objeto de estudo.

Os dados serão colhidos através de planilhas de coleta de dados, que poderão ser analisadas no item levantamento do inventário, de forma mais detalhada. As planilhas de coleta de dados foram desenvolvidas a partir do formato sugerido pela ABNT (2004), no anexo A da norma NBR ISO 14041, que regulamenta as formas de análise de inventário em avaliações de ciclo de vida, procurando adaptá-lo para os objetivos colocados nesse trabalho. Também será adotado o 
modelo de planilhas de coletas de dados do método de balanço social do Instituto Ethos, que tem levantamentos quantitativos e qualitativos, assim como os do ACV, porém com variáveis da dimensão social e econômica, adotando nesses casos levantamentos que possibilitarão uma futura correlação com os indicadores propostos pelos mesmos métodos, que são "[...] um parâmetro (propriedade medida ou observada) ou valor derivado de parâmetros que fornecem informações sobre um determinado fenômeno [...]", (OECD, 1993, apud SILVA, V. 2003). Assim, segundo Silva, V. (2003) esses indicadores podem:

a) reduzir o número de medidas e parâmetros necessários para descrever exatamente uma determinada situação. Conseqüentemente, o número de indicadores e o nível de detalhamento contido num conjunto de indicadores devem ser limitados. Por um lado, um índice único ou um número demasiadamente pequeno de indicadores podem ser insuficientes para prover a informação necessária ou podem incorrer em dificuldades metodológicas que crescem com o nível de agregação. Por outro lado, um número excessivo de indicadores tende a distorcer a visão geral que o conjunto supostamente deveria fornecer.

b) simplificar o processo de informação através do qual os resultados destas medidas chegam ao usuário final.

\section{VI) Os critérios de inclusão de entradas e saídas.}

A etapa de definição dos critérios de inclusão de entradas e saídas é um processo interativo que visa rastrear quais as classes de entradas e saídas serão coletadas a partir de critérios estabelecidos de acordo com o objetivo do estudo, por exemplo, fluxos de produtos que utilizem a maior quantidade de massa em matérias primas.

No objeto de estudo serão coletadas todas as entradas e saídas que foram identificadas nos processos através das observações diretas e das entrevistas, de acordo com a descrição das categorias de dados (que são mostradas no capítulo 4) e a delimitação da fronteira inicial do sistema apresentada acima. As entradas e saídas também serão agrupadas em classes de variáveis, para facilitar a coleta de dados. Como estabelecido na fronteira do sistema, a matéria prima "madeira de Pinus de terceira qualidade" será analisada como a cadeia principal, e quaisquer outros produtos e fluxos que interajam com o sistema de produto serão estudados como entradas e saídas. 
Até aqui foram apresentadas as definições do objetivo e escopo, referentes à primeira fase do Método APCV, aplicadas ao objeto de análise, o sistema estrutural de cobertura, experiência de produção realizada pelo projeto Inovarural no Assentamento Rural Pirituba II. Na seqüência, ainda neste capítulo, serão descritas as etapas da segunda e terceira fase do método.

\subsection{Análise do inventário do objeto de estudo.}

Essa etapa consiste na coleta de dados, quantitativos e qualitativos, e procedimentos de cálculo para quantificar as entradas e saídas pertinentes de um sistema de produto. Essa etapa também é interativa e à medida que o levantamento é feito podem ser encontrados novos requisitos ou limitações para o trabalho, podendo acarretar na mudança de objetivos. O levantamento deve ser feito considerando a unidade funcional adotada (por exemplo, $\mathrm{m}^{3}$ de cobertura produzida), preliminarmente estabelecida para assegurar que o fluxo de entrada de matéria prima (por exemplo, $2 \mathrm{~m}^{3}$ de madeira bruta de Pinus Elliottii) encontre uma saída quantificada como unidade funcional (produção de $1 \mathrm{~m}^{3}$ de cobertura), rejeitos (produção de $0,5 \mathrm{~m}^{3}$ de pó-de-serragem) e produtos intermediários (cinco peças pré-cortadas para encaixe das vigas). Essa etapa resulta nos dados de entradas (inputs) e saídas (outputs) de cada etapa do processo descritas nas planilhas de coleta de dados. Caso o sistema do produto possua produtos múltiplos, como no exemplo acima, deve ser feita uma alocação das matérias primas, energias, etc., utilizadas para cada produto intermediário.

Para se fazer a coleta de dados, a norma recomenda, além da documentação do processo de coleta de dados, a descrição de cada processo elementar e a utilização de fluxogramas; mas como a pesquisa se propõe a fazer uma análise pluridimensional, e não apenas ambiental, é necessário incluir as variáveis de outras dimensões na coleta de dados das entradas e saídas de cada processo. Vista a grande complexidade dessa coleta, desenvolveu-se uma nova ferramenta para obtenção do inventário do objeto de estudo denominada matriz de coleta de dados, que faz o cruzamento entre os diversos processos, representados na primeira linha, e as diferentes dimensões, representadas na primeira coluna. O cruzamento de cada dimensão com cada processo do sistema do produto gerará uma planilha de coleta de dados específica, onde serão levantados todos os dados referentes aos indicadores qualitativos e quantitativos da determinada dimensão naquela etapa da cadeia produtiva. Essas planilhas podem se apresentar em forma de questionários ou de levantamento de dados, e devem ser adaptadas para cada produto estudado, 
podendo ter suas variáveis também modificadas dependendo do objetivo e escopo delineados para o estudo.

Essas planilhas serão nomeadas com uma sigla formada pela letra inicial da dimensão e o número do processo, ver matriz na figura 25 , as planilhas com dados os coletados estão contidas nos anexos I e II.

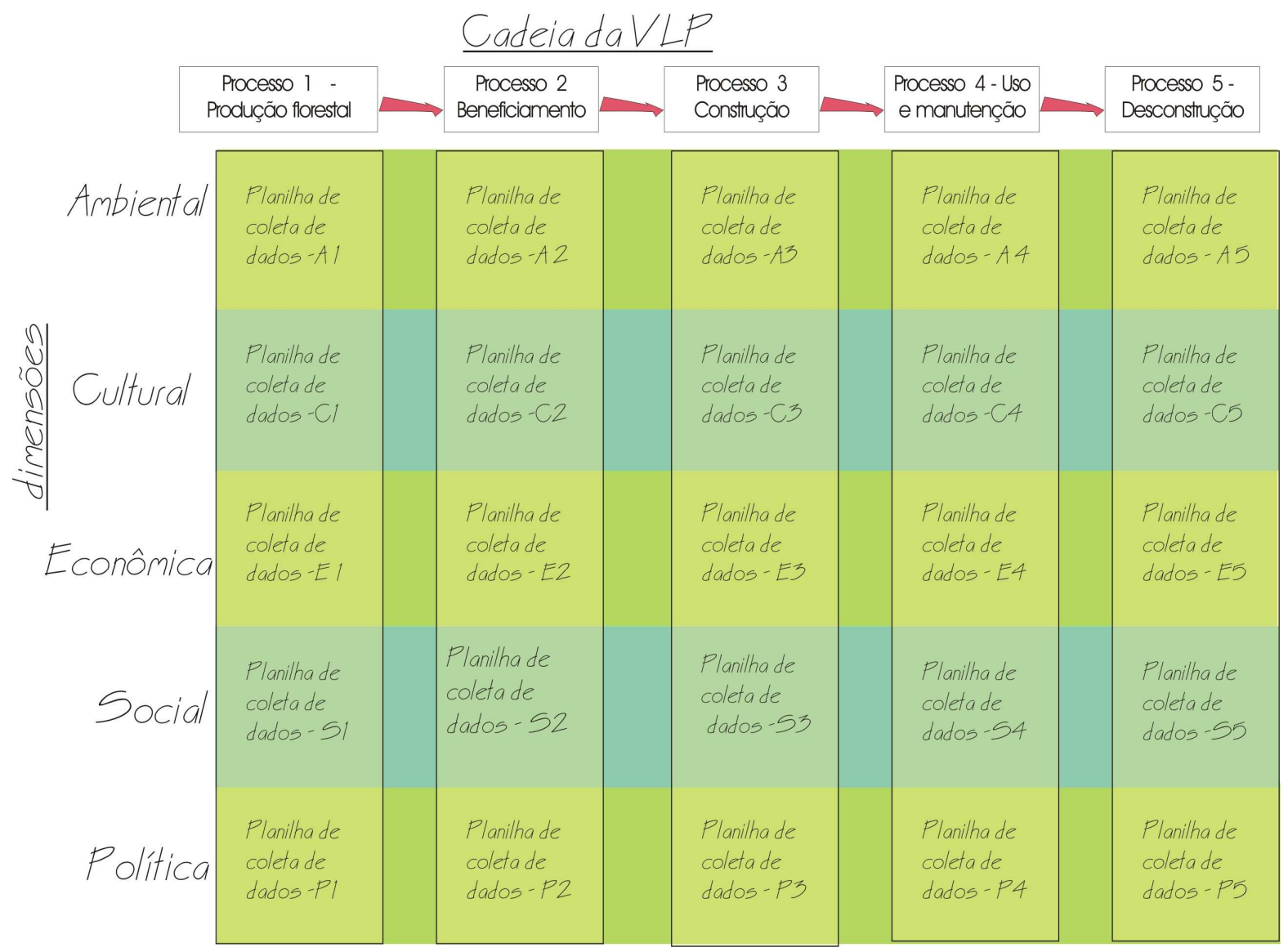

Figura 25: Matriz de coleta de dados da cadeia de produção de VLP. Fonte: Autor

Essa planilha foi criada com o intuito de organizar a grande quantidade de dados que devem ser coletados em uma análise pluridimensional e facilitar sua visualização. As planilhas de dados referentes ao processo 1 (produção florestal) foram coletados através de uma entrevista no dia 23 de abril de 2008, com o engenheiro florestal de uma empresa que localiza-se na cidade de Prata em Minas Gerais ( a empresa não concedeu a autorização para a publicação de seu nome, sendo denominada nesse trabalho pela letra "A"), e podem ser vistas no anexo I, a documentação foi feita através de registros pessoais e gravação de áudio. Será utilizado o levantamento fotográfico feito na mesma empresa por Partel (2006) para complementação dos dados e ilustração do processo. Também foi utilizado como fonte de dados para o levantamento nesse processo o 
balanço socioambiental feito pela empresa no ano de 2007, documento de livre acesso na internet, mas também disponibilizado no anexo II, em forma de CD (devido a sua extensão), junto com a planilha de levantamento social desse processo (S1). Deve-se realçar aqui que todo o levantamento de dados desse processo não foi feito na empresa que efetivamente forneceu as toras para o projeto de construção do sistema estrutural em Itapeva/SP (Eucatex), devido à sua falta de interesse em estabelecer a parceria para o fornecimento dos dados. Assim, a estratégia adotada foi fazer uma estimativa dos dados a partir do levantamento em outra empresa que pudesse fornecer os dados referentes à etapa de produção florestal de Pinus e utilizar parâmetros da realidade local para estimar os valores finais, como a distância entre a floresta e a serraria, dado fornecido pela serraria onde foi feito o beneficiamento da madeira.

As planilhas do processo 2 (beneficiamento) foram preenchidas durante a visita feita à serraria que beneficiou as madeiras de Pinus de $3^{a}$ qualidade para a construção do sistema estrutural nos dias 5 e 6 de julho de 2007, onde foram documentados os dados através de registros, relatos, entrevistas, medições in loco, fotografia e filmagem, sendo as planilhas A2, E2, P2 e C2 dispostas no anexo I, e a planilha S2 no anexo II, em forma de CD, devido à sua extensão.

As planilhas do processo 3 (construção) foram divididas em duas etapas: as planilhas da operação pré-fabricação foram preenchidas nos dias 19 e 20 de julho de 2007, durante a visita feita ao assentamento Rural Pirituba II em Itapeva, onde foram pré-fabricadas as madeiras de Pinus de $3^{\text {a }}$ qualidade para a construção do sistema estrutural, e foram documentados os dados através de registros, relatos, entrevistas, medições in loco, fotografia e filmagem. Esses dados foram complementados e preenchidos também com a observação direta, registros em gaveta, e relatórios científicos escritos pela equipe técnica que assessorou a construção das habitações; mesma prática utilizada para preenchimento dos dados da operação de montagem, feito durante as visitas ao assentamento Rural Pirituba II na viagem dos dias 24 a 26 de outubro de 2007. A planilha de levantamento social foi preenchida durante a visita à Marcenaria Coletiva Madeiarte, no assentamento Rural Pirituba II, durante a viagem dos dias 21 a 23 de novembro de 2007, e está contida no anexo II, em forma de CD, enquanto todas as outras planilhas desse processo estão contidas no anexo I.

As planilhas A4 e E4, do processo 4 de uso e manutenção, e as planilhas A5 e E5, do processo 5 de desconstrução, foram preenchidas com valores estimados a partir de revisões bibliográficas e das recomendações de uso e manutenção feitas pela assessoria técnica e pelos fabricantes dos materiais envolvidos devido ao pouco tempo de uso e manutenção do objeto empírico, não tendo alcançado ainda os períodos recomendados para a primeira manutenção e nem para a sua 
desconstrução. As planilhas C4, P4, C5 e P5 foram preenchidas de acordo com as entrevistas feitas com moradores nos dias 18 a 20 de fevereiro de 2008, além dos relatórios elaborados por assessores, que colocaram algumas observações sobre a previsão de impactos culturais e políticos dessa experiência. Todas essas planilhas estão contidas no anexo I do trabalho. As planilhas S4 e S5 de caráter organizacional não puderam ser preenchidas, pois não houve nenhuma empresa envolvida nessas operações e o levantamento não é aplicável para o edifício.

\subsubsection{Descrição dos processos envolvidos na cadeia de produção da VLP.}

Seguindo a recomendação da norma e visando uma maior clareza dos processos envolvidos nesse ciclo de vida para uma posterior análise e correlação com os dados obtidos no inventário, faz-se necessária uma descrição de seus processos e etapas envolvidos na produção das VLPs.

- Processo de produção florestal: nesse processo serão considerados somente os plantios referentes à silvicultura intensiva com espécies do Pinus sppp e é composto pelas operações de plantio, que contemplam a seleção de espécies, preparação do solo com fertilização, controle de ervas daninhas e controle de pragas e insetos (YUBA, 2005); pela operação de manejo, que consiste em "um conjunto de tratamento aplicados a uma floresta durante uma rotação" (OPIE; CURTIN e INCOLL, 1978, p.180 apud YUBA, 2005); e pela colheita, que se trata do "seccionamento da árvore em sua porção inferior através de ferramentas automáticas ou manuais, com ou sem motorização, seguido do desgalhamento da tora e corte em dimensões de comprimento padrão, a fim de viabilizar seu transporte ou facilitar o manuseio e movimentação das peças" (GONÇALVES, 2000). No quadro 8 será apresentada a subdivisão do processo de produção florestal, com informações retiradas da entrevista realizada com a empresa A.

Quadro 8: Operações e suboperações do processo de produção florestal.

1- O plantio das mudas é feito em quatro etapas:

- controle de pragas com aplicação de formicida granular à base de sufloramida (atamex) e herbicida granular à base de glifosati (escalti) diretamente no solo,

- aplicação de cupinicida líquido (canfidor) nas mudas por imersão,

- preparação do solo através da subsolagem com um trator, que faz os "riscos" a cada $3 \mathrm{~m}$ a uma profundidade de $40 \mathrm{~cm}$ e aplica automaticamente a adubação do solo com fosfato,

- posicionamento das mudas dentro dos "riscos" em um espaçamento de $2 \mathrm{~m}$.

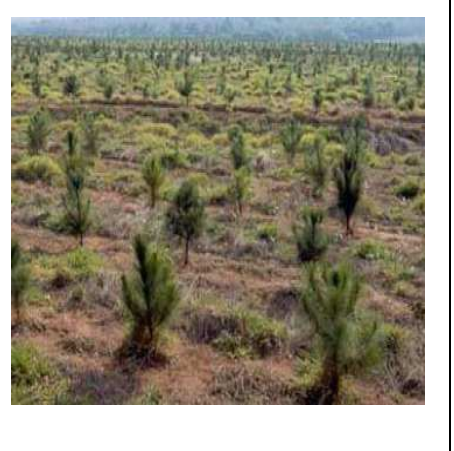


2- É feito um controle de pragas regularmente durante todo o ciclo de produção, aplicando-se:

- $1,8 \mathrm{~kg}$ de herbicida à base de glifosati por ha, 2 vezes por ano até $05^{\circ}$ ano

- $0,5 \mathrm{~kg}$ de formicida à base de sufloramida por há, 2 vezes por ano até o $25^{\circ}$ ano.

3- São feitas 3 desramas (corte de parte dos galhos da copa):

- $1^{\text {a }}$ desrama entre o $3^{\circ}$ e $4^{\circ}$ ano com a retirada de $40 \%$ da copa das árvores

- $2^{\mathrm{a}}$ desrama entre o $5^{\circ}$ e $6^{\circ}$ ano com a retirada de $30 \%$ da copa das árvores

- $3^{\text {a }}$ desrama entre o $7^{\circ}$ e $8^{\circ}$ ano com a retirada de $30 \%$ da copa das árvores.

4 - São realizados 2 desbastes (corte de parte dos talhões):

- $1^{\circ}$ desbaste entre o $7^{\circ}$ e $8^{\circ}$ ano, retirando $20 \%$ das árvores (as que apresentam mais defeitos, como baixo crescimento, tortuosas, etc), com rendimento de 7 árvores $/ \mathrm{m}^{\text {st }}$ e $35 \mathrm{~m}^{\text {st }} / \mathrm{ha}$.

- $2^{\circ}$ desbaste entre o $11^{\circ}$ e $12^{\circ}$ ano, retirando $16 \%$ das árvores (para facilitar o crescimento das remanescentes), com rendimento de 3,5 árvores $/ \mathrm{m}^{\text {st }}$ e $40 \mathrm{~m}^{\text {st }} / \mathrm{ha}$.
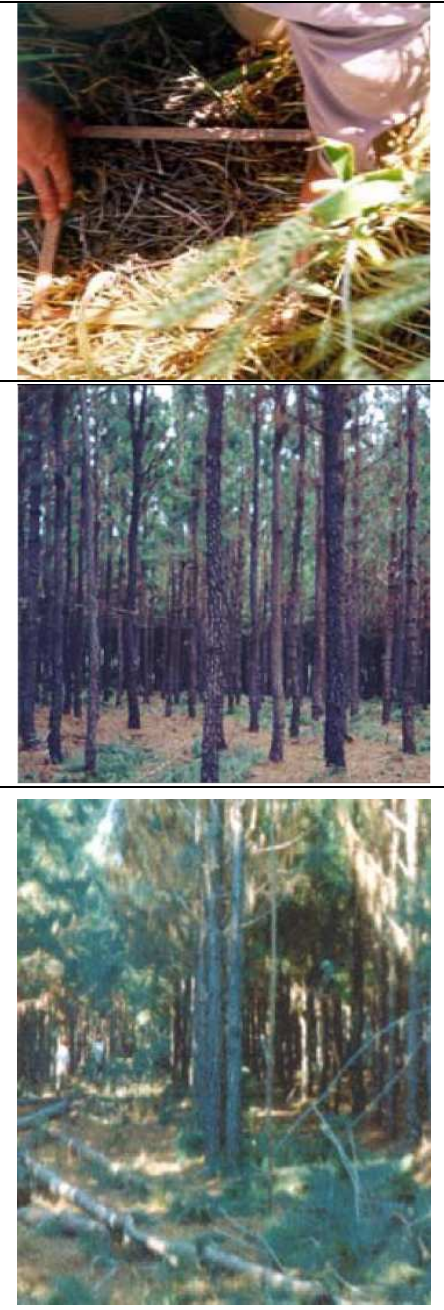

5- É feito o corte raso (retirada de todas as árvores do talhão) de $100 \%$ da área com motosserra, apresntando rendimento de 402 $\mathrm{m}^{\mathrm{st}} / \mathrm{ha}$. A empresa tem 10 áreas com anos de plantios diferentes.

6- É feito o traçamento (corte das toras nos comprimentos desejados) com motosserra, e depois é feito o carregamento e transporte para fora do talhão com um trator com carroça acoplada.

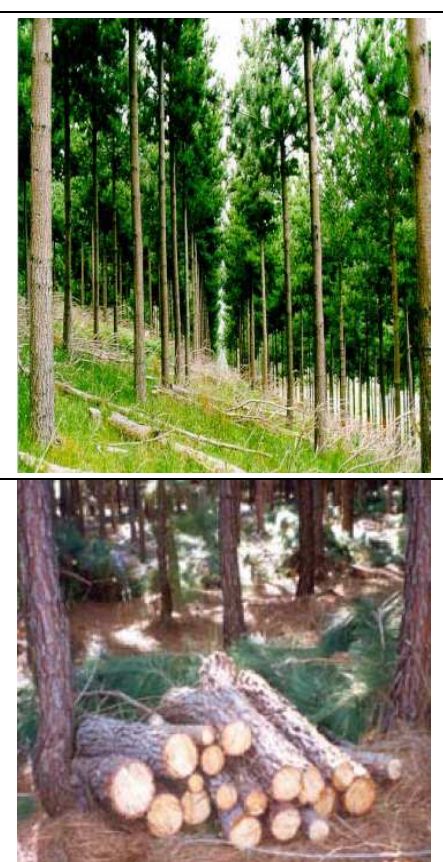

Fonte: Entrevista realizada dia 23/04/2008 com eng florestal da empresa "A" e fotos de Partel (2005). 
- Processo de beneficiamento: o processo de beneficiamento da madeira consiste na operação de desdobro da tora, definido por GONÇALVES (2000) como o "processo de corte longitudinal das toras, com ou sem casca, empregando na produção de peças na forma de pranchas, tábuas, vigas, vigotas, caibros, sarrafos ou ripas"; e na operação de secagem, definida por MARTINS (1988) como: "processo de redução do seu (madeira) teor de umidade a fim de levá-la a um teor de umidade definido, com o mínimo de defeitos, no menor tempo possível e de forma economicamente viável, para o uso a que se destina”.

No quadro 9 será apresentada a decomposição do processo de beneficiamento da madeira e suas operações de desdobro e secagem em algumas etapas de sua produção, colocando alguns dados referentes a consumo de matérias primas e produção de resíduos gerados mensalmente pela serraria.

Quadro 9: Processo de beneficiamento da madeira de Pinus de $3^{\text {a }}$ qualidade e dados da produção mensal.

1- Transporte das toras de Pinus do pátio para a área do galpão onde será feito o desdobro. Utilização de $\mathrm{m}^{\text {st }}$ de toras/mês, de diversos comprimentos e das espécies Pinus elliottii e Pinus taeda, sem controle de proporções.

2- Desdobro (retirada de 2 peças com costaneiras da tora) pela serragem em uma serra circular quádrupla.

3- Desdobro (retirada de 2 peças com costaneiras para produção da peça do bloco central) pela passagem em uma serra circular quádrupla.

4- Refilo das peças de aproveitamento da costaneiras em uma serra circular múltipla para definição da largura.

5- Desdobro das peças de aproveitamento das costaneiras na serra de fita horizontal. (São passadas quantas vezes forem necessárias para o aproveitamento de toda a peça).
Essas seis etapas (da 2 a 7) utilizam como matéria prima $8000 \mathrm{~m}^{\text {st }} / \mathrm{mês}$ e com o desdobro produzem 2000 $\mathrm{m}^{\text {st }} / \mathrm{mês}$ de madeira serrada, sendo $1400 \mathrm{~m}^{3}$ de $1^{\mathrm{a}}$ qualidade, $400 \mathrm{~m}^{3}$ de $2^{\mathrm{a}}$ qualidade e $200 \mathrm{~m}^{3}$ de $3^{\mathrm{a}}$ qualidade, resultando em um rendimento de $4 \mathrm{~m}^{\text {st }} / 1 \mathrm{~m}^{3}$ de madeira serrada, sendo $70 \%$ de $1^{a}$, $20 \%$ de $2^{\mathrm{a}}$ e $10 \%$ de $3^{\mathrm{a}}$ qualidades. Além disso são produzidos 700 $\mathrm{m}^{3} / \mathrm{mês}$ de pó-de-serra (esse subproduto é vendido a granjas e haras para ser usado como forração para os animais, e depois é vendido e utilizado como esterco para agricultura) e $2600 \mathrm{~m}^{3} / \mathrm{mês}$ de cavaco (vendido para empresas que o utilizam como fonte de energia para aquecer caldeiras ou outros fins energéticos.
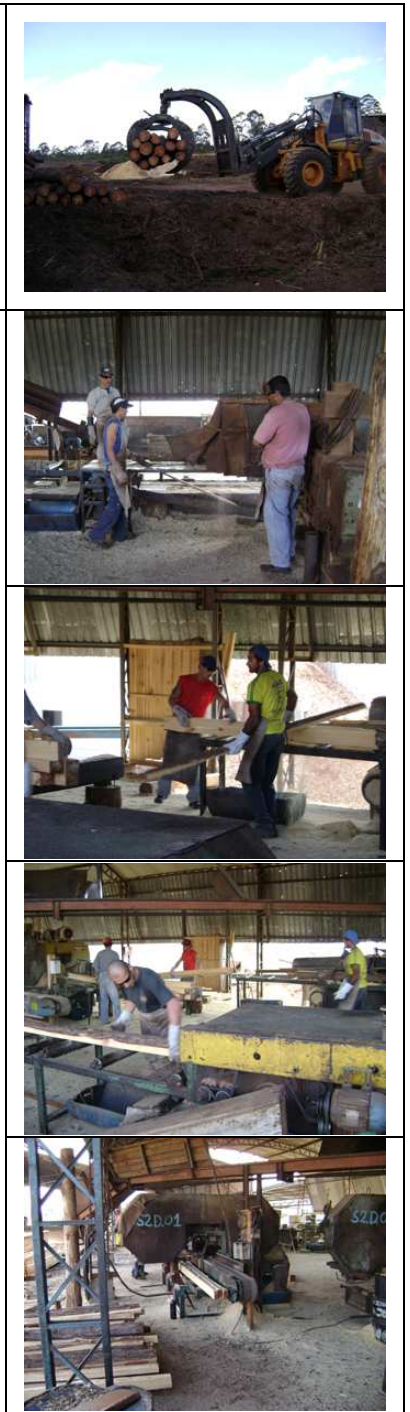


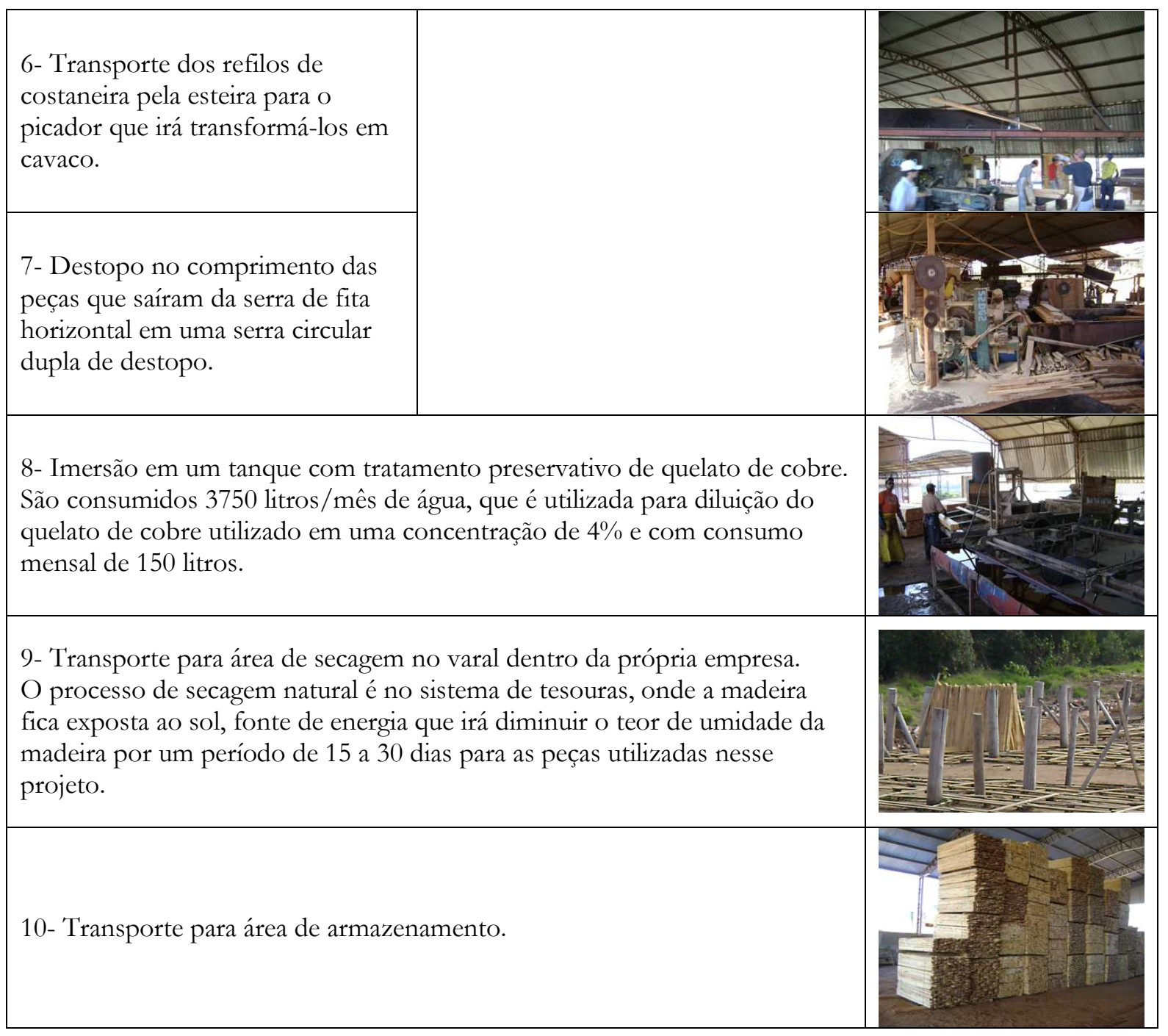

Fonte: Entrevista realizada com gerente da serraria Brancalhão no dia 05 e 06 / 07 / 2007.

- Processo de construção: é dividido nas operações de pré-fabricação, montagem e tratamento, que em diferentes experiências podem ter maior ou menor relevância. Em alguns casos praticamente não existe pré-fabricação, constituindo um sistema artesanal ou tradicional, enquanto em outros, essa pode ser uma operação fundamental, como no caso do objeto de estudo, aproximando-se do sistema racionalizado ou semi-industrializado. Na operação de préfabricação é feita a usinagem e montagem parcial das vigas laminadas pregadas; na operação montagem as vigas pré-fabricadas são posicionadas, chumbadas e travadas; e na operação tratamento aplica-se o tratamento preservativo da madeira por aspersão com bomba costal, após a fixação das vigas no edifício. O quadro 10 apresenta a seqüência de produção das vigas laminadas pregadas e alguns dados de sua produção para as 36 habitações, e referem-se apenas às VLP simples, tendo os outros componentes (VLP composta, de beiral e varanda) processos diferentes; porém os dados apresentados referem-se à produção de todos os tipos de 
componentes. Essa metodologia foi adotada pois o foco do trabalho está na obtenção e análise dos dados, e não no estudo aprofundado da técnica de produção.

Quadro 10: Etapas da pré-fabricação e dados da produção das 36 habitações.

1- Seleção das peças de madeira serrada de Pinus de $3^{a}$ qualidade. Foram utilizados 134,743 $\mathrm{m}^{3}$ de madeira de $3^{\mathrm{a}}$ qualidade de Pinus (espécie elliottii e taeda), sendo que $19,7 \mathrm{~m}^{3}$ das peças foram rejeitas para fins estruturais nessa seleção, o que equivale a $14,62 \%$ de perdas. Essas peças rejeitadas foram recolhidas pelos moradores e tiveram outros fins, tais como passarinheiras, prateleiras ou confecção de ferramentas para o trabalho rural.

2- Refilo da face (menor) das peças selecionadas na serra circular

A etapas 2, 3 e 5 utilizaram 115,043 $\mathrm{m}^{3}$ de madeira de Pinus de terceira qualidade para produção de $99,54 \mathrm{~m}^{3}$ de componentes pré-fabricados e geraram 15,48 $\mathrm{m}^{3}$ de resíduos entre pó-de-serra, refilos, destopos e cepilho. O pó-de-serragem e cepilho foram vendidos para forração de chiqueiros e de criação de galinhas, e poderá ser

3- Destopo das peças refiladas nos comprimentos da pré-fabricação na serra circular esquadrejadeira. utilizada posteriormente como adubo. Os refilos e destopos poderiam ainda ser vendidos para obtenção de energia calorífica em fornos.

4- Posicionamento na mesa de produção com gabarito e pregagem. Nessa etapa foram utilizados 772,68 kg de pregos 17 x 27 e 18,93 $\mathrm{kg}$ de pregos $15 \times 15$, sendo que em média $15 \%$ desses, ou seja, $118,74 \mathrm{~kg}$, foram entortados e inutilizados.

5- Regularização da face da VLP não uniforme na desempenadeira
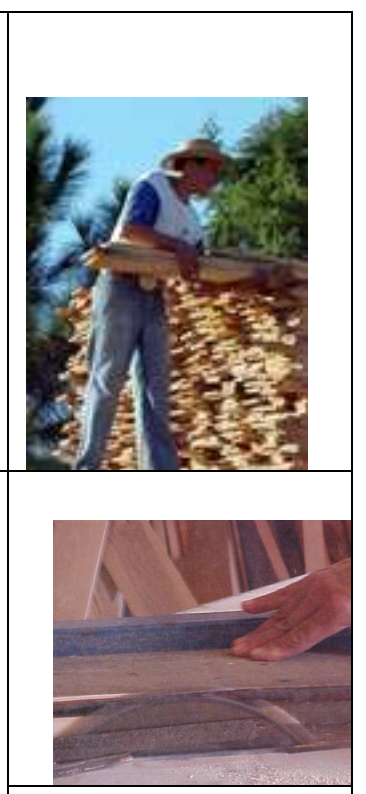

\begin{tabular}{|l|l|l|}
\hline 5- Regularização da face da VLP não uniforme na desempenadeira & & \\
\hline 6- Armazenamento das vigas prontas. & & \\
\hline
\end{tabular}

Fonte: Autor e Grupo de pesquisa Habis 
O quadro 11 a seguir apresenta o processo de montagem de todo o sistema de vigas laminadas pregadas.

Quadro 11: Etapas da operação de montagem do sistema estrutural em canteiro e dados da montagem das 36 habitações.

1- Chumbamento das vigas compostas e peças de berço na alvenaria.

Foram necessários 1260 parafusos sextavados de 3/8' X 1' com bucha, além de $3,17 \mathrm{~m}^{3}$ do componente "berço", já pré-fabricado. Não existem resíduos devido à racionalização do sistema.

2- Posicionamento das vigas laminadas pregadas no espaçamento da galga das telhas, utilizando-se todos os componentes restantes em vigas laminadas pregadas já pré-fabricadas $\left(96,37 \mathrm{~m}^{3}\right.$ de componentes). Não existem resíduos devido à racionalização do sistema.

Pregação dos chapuzes para fixação das vigas nos berços.

Nessas duas etapas ( 3 e 4) são utilizados $187,92 \mathrm{~kg}$ de pregos 17 × 27 e $4,32 \mathrm{~kg}$ de pregos $15 \times 15$, além de $1296 \mathrm{~m}$ de cabo de aço 1/8', 216 clips de aço e 216 chapas de aço de $2 \mathrm{~mm}$ e seção $3 \times 10 \mathrm{~cm}$. Também são utilizados $3,6 \mathrm{~m}^{3}$ de componentes de

4- Pregação dos espaçadores e passagem do cabo de aço para travamento do sistema estrutural. eucalipto (chapuzes e espaçadores) préfabricados. Não são gerados resíduos devido à racionalização do sistema.

5- Aplicação do tratamento preservativo à base de cipermetrina por aspersão com uma bomba costal. Para o tratamento preservativo foram utilizados inicialmente dois produtos, o ácido pirolenhoso durante o processo de préfabricação e a cipermetrina. Não foi possível comprovar a eficiência do ácido pirolenhoso e, portanto, o seu uso foi desaconselhado para o processo de produção das VLPs, recomendando-se somente a aplicação do tratamento preservativo à base de cipermetrina por aspersão superficial. Foram utilizados 648 litros do produto.

Fonte: Autor e Grupo de pesquisa Habis.

- Operação uso: usualmente essa operação é abordada verificando-se os desempenhos da edificação, e como nesse caso específico o objeto de estudo é o sistema estrutural, serão abordados somente os desempenhos mostrados no sub-item I- Funções do Sistema do item 3.3.2, não havendo a necessidade de se verificar alguns tipos de desempenho, como o térmico, lumínico, etc.

- Operação manutenção: essa operação está diretamente ligada à vida útil de uma edificação e seu desempenho, consumo de materiais e capital, segundo a ABNT (2002); e, para que 
permaneça em condições de desempenho mínimo para atender as exigências de um usuário, deve seguir as recomendações de manutenção dos projetistas e fabricantes, que serão específicas para cada caso. $\mathrm{O}$ autor coloca através de um gráfico, apresentado na figura 26, a relação de algumas dessas variáveis.

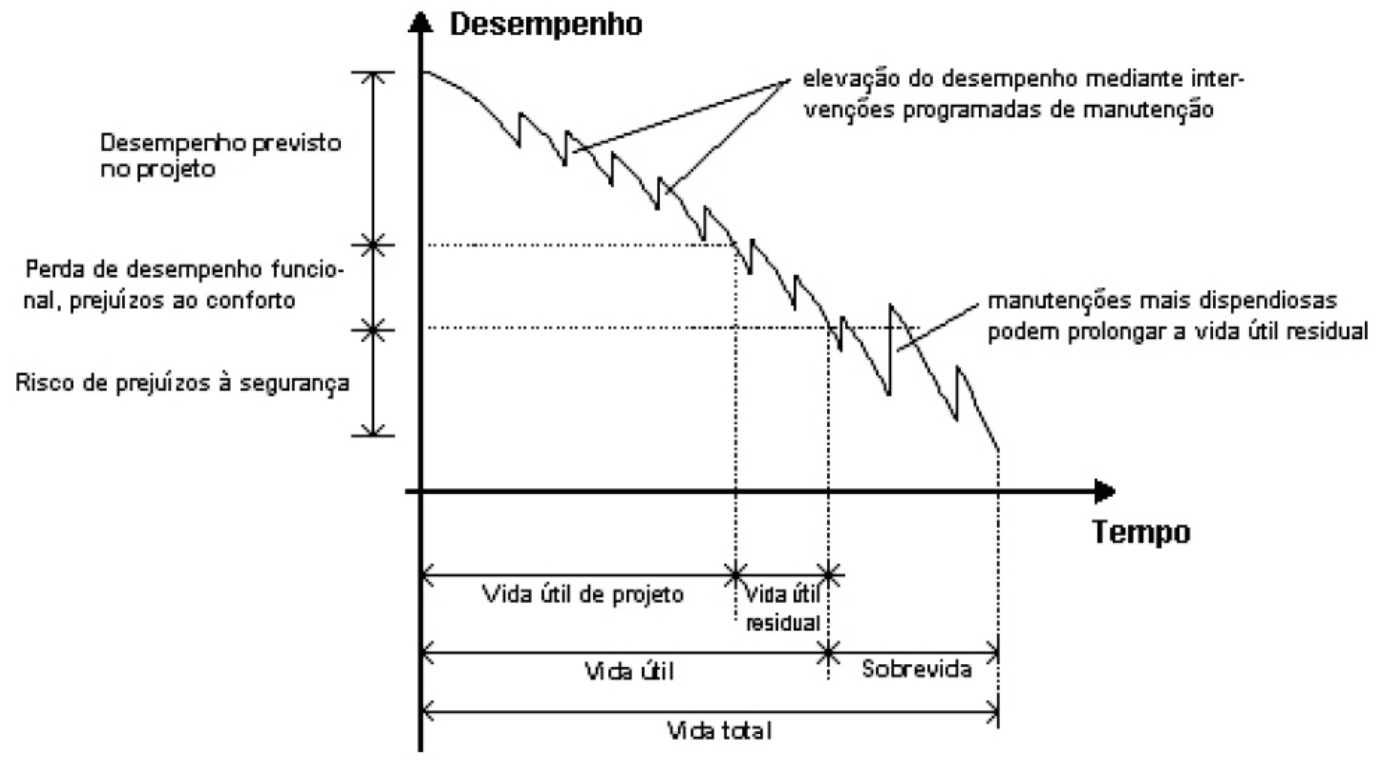

Figura 26: Desempenho ao longo do tempo. Fonte: ABNT (2002)

A manutenção desse sistema estrutural baseia-se em reaplicar o produto preservativo a cada cinco anos, como recomenda o fabricante. Para a manutenção será utilizado o horizonte de 50 anos de vida útil do sistema estrutural (ver definição da unidade funcional), portanto serão necessárias 8 aplicações do tratamento preservativo à base de cipermetrina, considerando a primeira aplicação feita durante a etapa de montagem no processo de construção e que a última aplicação não será necessária pois o sistema será desconstruído. Portanto serão consumidos 5184 litros do tratamento para a manutenção das 36 habitações ao longo dos 50 anos, e caso a vida útil do sistema se prolongue, esse número de aplicações aumentará, porém esse cenário não será considerado nesse trabalho.

- Operação de desconstrução: essa operação consiste no reaproveitamento, reuso, reciclagem ou disposição final de todos os componentes que faziam parte do sistema de produto estudado. Cada sistema vai necessitar de cuidados diferentes, porém é necessário salientar que a visão de sustentabilidade colocada anteriormente requer uma mudança no tradicional pensamento linear de "deposição dos resíduos no fim da cadeia" para um pensamento cíclico, de re-introdução do material na forma de reaproveitamento, reuso ou reciclagem (YUBA, 2005). 
De forma geral essa operação necessita somente de ferramentas simples (como martelos e marretas), e caso as VLPs tenham um reuso para outros fins que não estruturais (como na confecção de cavaletes, gabaritos de obra, etc.) algum fluxo de material ainda poderia ser incorporado ao sistema desse produto, porém esse caso não será estudado, sendo analisado o descarte final dos componentes. Segundo o fabricante do produto preservativo é necessário que todos os materiais tratados sejam depositados em aterros devidamente preparados, onde o material lixiviado será armazenado, evitando possíveis contaminações no solo ou na água devido à presença da cipermetrina nesse material.

\subsubsection{Bases referenciais para cálculo dos dados}

Bases referenciais são referências obtidas na bibliografia para se estimar entradas e saídas não levantadas no inventário, ou referências necessárias para a transformação de dados brutos do inventário em dados que possam ser usados nas categorias de impactos que serão estudadas, ou bases para alocações de fluxos dentro de um processo elementar que, segundo a ABNT (2004), devem ser explicitadas para se criar uma base de dados confiável para futuras comparações.

Essas referências serão apresentadas dentro de algumas categorias de impactos: uso de água, uso de energia, uso de matéria prima e geração de resíduos e emissões de poluições para o ar, solo e água, que são as mesmas categorias utilizadas para a avaliação dos impactos ambientais (cuja seleção estão descritas no capítulo 4), que serão descritas abaixo.

\section{I) Bases referenciais para cálculo dos dados de uso de matéria-prima e geração de resíduo}

De forma geral todas as entradas de matérias primas e gerações de resíduos foram medidas in loco ou levantadas através de entrevistas. Deve-se ressaltar a especificidade do processo de produção florestal, onde além da utilização de produtos tem-se a utilização de recursos naturais como o solo, do qual não serão calculados os consumos de nutrientes necessários para o crescimento das árvores, somente sua área necessária para plantação. Nesse processo também se destaca que existe uma "produção" de matéria prima com a entrada de poucos quilos de insumos e fixação do carbono da atmosfera para haver o crescimento das árvores e gerando assim mais massa de matéria prima no final do processo do que em seu início, que será representado como sinal de menos "_" nas tabelas de consumo de matéria prima. A produção de resíduos nessa fase não será quantificada, pois todos os resíduos (galhos e acículas) são deixados ao solo para serem decompostos e servir como adubo para futuros plantios. 
Em alguns processos houve a necessidade de alocação de fluxos, que é a divisão proporcional de determinado fluxo quando a partir deste são gerados diferentes produtos. Por exemplo, no caso do processo de beneficiamento, uma determinada quantidade de toras é utilizada para a operação de desdobro, gerando $70 \%$ de madeira de $1^{\mathrm{a}}$ qualidade, $20 \%$ de $2^{\mathrm{a}}$ e $10 \%$ de $3^{\mathrm{a}}$, em massa de madeira processada. Assim, considerando as recomendações da ABNT (2004), que propõe uma das formas de se fazer a alocação de matérias primas através da porcentagem em massa dos produtos, e considerando que as madeiras possuem em média a mesma densidade, tem-se que $10 \%$ da massa de matéria prima é utilizada para a produção da madeira serrada de $3^{a}$ qualidade, $20 \%$ para a de $2^{\mathrm{a}}$ e $70 \%$ para a de primeira.

A mesma recomendação também é utilizada para determinar algumas porcentagens de resíduos na serraria, então será considerado que a madeira de $3^{\text {a }}$ qualidade gerou $10 \%$ em massa do total de resíduos da serraria, já que os resíduos gerados pelas madeiras de $1^{\mathrm{a}}, 2^{\mathrm{a}}$ e $3^{\mathrm{a}}$ qualidade têm a mesma densidade. É importante salientar que em uma situação ideal seria recomendado um estudo mais aprofundado para esse tipo de alocação, pois estima-se que a madeira de terceira qualidade gera mais resíduos (pó-de-serra) do que as madeiras de $1^{\mathrm{a}}$ e $2^{\mathrm{a}}$ qualidade por passar por mais processos em serras.

O cálculo de geração de resíduos nas etapas de pré-fabricação e montagem foram feitos a partir da subtração do volume inicial de madeira comprada $\left(134,743 \mathrm{~m}^{3}\right.$ de madeira de $3^{\text {a }}$ qualidade de Pinus) do volume final dos componentes produzidos (99,54 $\mathrm{m}^{3}$ de componentes pré-fabricados). Nesse caso não foi necessário fazer a alocação de resíduos, pois não havia diferentes produtos sendo fabricados com a mesma matéria prima.

Para saber a quantidade em massa de matéria prima utilizada na produção da madeira serrada, partir-se-á do aproveitamento médio das toras, que segundo Kronka et al (2005) é de 50\% do volume total, considerando toras de diâmetro médio de $30 \mathrm{~cm}$. Em seguida, os volumes obtidos serão transformados em massa a partir das seguintes densidades dadas pela ABNT (7190): madeira de Eucalipto Grandis (utilizada na montagem) com densidade igual a $640 \mathrm{~kg} / \mathrm{m}^{3}$ e madeiras de Pinus elliotti e Pinus Taeda com $560 \mathrm{~kg} / \mathrm{m}^{3}$ e $645 \mathrm{~kg} / \mathrm{m}^{3}$ respectivamente, onde será considerada a média entre as duas últimas densidades, visto que não há nenhum controle de porcentagem na utilização das duas espécies. 


\section{II) Bases referenciais para cálculo dos dados de uso de água}

Com relação ao uso da água é importante salientar que nesse estudo se desconsiderará o consumo de água para abastecimento do escritório e outros usos secundários, ficando somente focados nos fluxos de água diretamente usados no produto, sendo esses obtidos através de observação direta ou entrevistas no local.

No processo de produção florestal não é utilizada irrigação, portanto todo o consumo de água desse processo (para o crescimento das árvores) é de fonte pluvial sem nenhum tipo de intervenção do homem, e por isso não será calculada.

\section{III) Bases referenciais para cálculo dos dados de uso de energia}

Segundo o CANADIAN WOOD COUNCIL (1997) a energia utilizada no processo de construção, e principalmente em seu período de uso e manutenção, é um dos fatores mais importantes para a avaliação da sustentabilidade, e se dá no consumo de energia elétrica, para iluminação e resfriamento, etc, e energia calorífica, para aquecimento ou outros fins.

No capítulo 5 ambas as energias serão comparadas, fazendo-se a conversão de Kcal para KWh e para a equivalência das diferentes fontes de energia. Anteriormente, segundo Mafra (2006), referenciava-se a quantidade de energia em óleo combustível necessária para gerar eletricidade (1 $\mathrm{kWh}$ equivalia a $3132 \mathrm{kcal}=0,29$ tep $^{5}$ ), mas atualmente essa comparação é feita através da conversão direta em energia, através da equivalência: $1 \mathrm{kWh}$ equivale a $860 \mathrm{kcal}=0,086$ tep.

\section{a) Energia calorífica:}

A energia calorífica utilizada é proveniente majoritariamente de combustíveis fósseis, como o óleo diesel, utilizado para movimentar caminhões e máquinas que fazem o transporte das matérias primas e produtos da cadeia estudada. É importante salientar que todos os processos de transporte foram incluídos à montante de cada processo elementar, ou seja, em cada processo será analisado o transporte de suas matérias primas da cadeia principal (da madeira de Pinus), mas não serão estudadas as entradas dos produtos de outros sistemas. O cálculo é feito a partir das distâncias levantadas nas planilhas de coleta de dados entre o local onde ocorre determinado processo e seu fornecedor. Para cálculo do consumo de combustível tomou-se como referência o consumo médio de caminhões de grande porte levantado por Bartholomeu (2006) através de medições em uma frota nacional, considerando as condições das estradas no estado de São Paulo

\footnotetext{
${ }^{5}$ tep $=$ tonelada equivalente de petróleo
} 
como uma das variáveis que influenciam nessa média. Chegou-se então a um consumo médio de 0,5485 litros/km e 0,5913 litros/km para os caminhões das marcas Scania e Mercedez Benz respectivamente, e adotar-se-á o valor de 0,5485 litros $/ \mathrm{Km}$, pois a majoração de valores pode influenciar negativamente na análise da sustentabilidade. Também serão utilizados os valores de consumo médio para tratores de 4 cilindros e $78 \mathrm{cv}$ de potência (porte médio) levantados por Silva, et al (2007), chegando-se a 9,53 litros de óleo diesel por hora. Para o uso da motosserra foi utilizado o consumo máximo de 1,77 litros de gasolina por hora ${ }^{6}$, segundo fabricante da marca Tekna para o modelo de $51 \mathrm{cc}$, indicado para o corte de árvores.

Como base para conversão dos volumes de combustíveis em poder calorífico inferior e para as conversões das medidas de energia, será utilizado o quadro 12, que contém os dados mais atuais disponíveis pela Agência Nacional do Petróleo da média dos combustíveis nacionais.

Quadro 12: Quadro de conversões do anuário estatístico de 2006 da ANP.

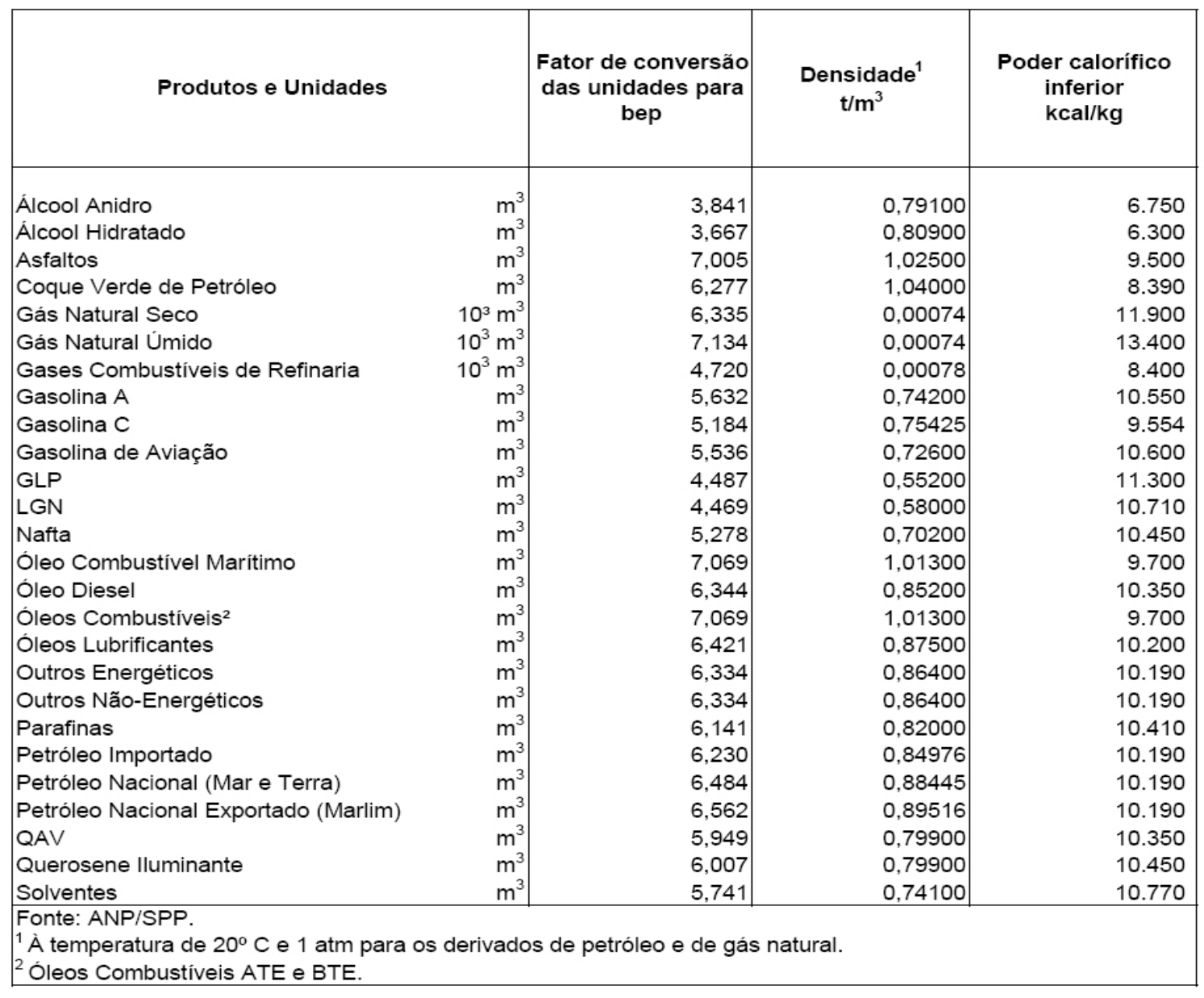

Fonte: Agencia Nacional de Petróleo (2006).

\footnotetext{
${ }^{6}$ Informação retirada do site do fabricante.
} 
Os dados referentes às distâncias percorridas, ao meio de transporte utilizado, à capacidade de carga dos caminhões e sua carga real transportada e o retorno do caminhão vazio ou não, além do consumo de combustível por outras fontes, foram coletados a partir das planilhas de coleta de dados econômicos, ambientais e no item de emissões de gases.

Somente no processo de beneficiamento de madeiras houve a geração de energia, proveniente da queima dos cavacos produzidos a partir das costaneiras de Pinus picadas e utilizados em fornos de indústrias. O cálculo também foi estimado por bibliografia, que faz a relação da produção de energia com seu poder calorífico e massa, calculada através da densidade dos resíduos. Segundo Brand et al (2004) a densidade do cavaco de Pinus varia da seguinte forma:

Quadro 13: Valores de densidade básica de resíduos armazenados por seis meses.

\begin{tabular}{|l|c|c|c|c|}
\hline \multicolumn{5}{|c|}{ Densidade básica (kg/m3) } \\
\hline & $\begin{array}{c}\text { Amostra } \\
\text { recém chegada }\end{array}$ & 1 mês & 4 meses & 6 meses \\
\hline Cavaco de Pinus & 303 & 244 & 267 & 237 \\
\hline Pó de serra & 246 & 167 & 165 & 172 \\
\hline
\end{tabular}

Fonte: adaptado de BRAND et al (2004)

Segundo o mesmo autor, para cálculo do poder calorífico deve-se usar o poder calorífico líquido (PCL), que considera o teor de umidade do elemento estudado, pois o PCS (poder calorífico superior) considera o material em peso anidrido, que não corresponde à realidade; assim o poder calorífico do cavaco de Pinus será utilizado da seguinte maneira:

Quadro 14: Poder calorífico líquido dos resíduos, em função do tempo de armazenamento.

\begin{tabular}{|l|c|c|c|c|c|c|}
\hline & \multicolumn{2}{|c|}{ Recém chegado } & \multicolumn{2}{c|}{$\mathbf{1}$ mês } & \multicolumn{2}{c|}{ meses } \\
\hline & $\begin{array}{c}\text { PCL } \\
(\mathrm{Kcal} / \mathrm{kg})\end{array}$ & $\begin{array}{c}\text { Teor de } \\
\text { umidade }\end{array}$ & $\begin{array}{c}\text { PCL } \\
(\mathrm{Kcal} / \mathrm{kg})\end{array}$ & $\begin{array}{c}\text { Teor de } \\
\text { umidade }\end{array}$ & $\begin{array}{c}\text { PCL } \\
(\mathrm{Kcal} / \mathrm{kg})\end{array}$ & $\begin{array}{c}\text { Teor de } \\
\text { umidade }\end{array}$ \\
\hline Cavaco de Pinus & 1550 & 56 & 2808 & 31 & 3652 & 15 \\
\hline
\end{tabular}

Considerando que o cavaco não é armazenado, sendo transportado assim que é produzido na quantidade suficiente para encher a carga de um caminhão para as fábricas que logo o utilizarão como fonte de energia, ele será enquadrado dentro da categoria amostra recém chegada, pois não se atinge um mês entre sua produção e utilização. Assim, seguindo as informações dos quadros acima e a produção de cavaco da serraria que será estudada $\left(8000 \mathrm{~m}^{\text {st }}{ }^{7}\right.$ de toras produzem $2600 \mathrm{~m}^{\text {st }}$ de cavacos), tem-se que para cada metro estéreo de toras de Pinus são produzidos 98,47 $\mathrm{kg}$ de cavaco, o que equivale a 152636,25 Kcal.

\footnotetext{
${ }^{7}$ Metro estéreo, volume de tora calculado incluindo-se os vazios entre as toras, sistema de medição utilizado no caminhão carregado de toras.
} 


\section{b) Energia elétrica:}

- Processo de beneficiamento: não foi possível fazer medições na serraria para o cálculo de gasto com energia elétrica nesse processo, portanto será adotado o método de pesquisa bibliográfica para sua estimativa. Barbosa (2003) apresenta um levantamento do consumo energético de sete serrarias que desdobravam toras de Pinus dos municípios de Itapeva e Itararé, com valores do consumo energético de cada equipamento utilizado no processo de desdobro das toras e do consumo total de energia utilizada durante o mês e sua relação com a produção de madeira serrada. Esses valores foram adotados como referência pois representam uma realidade, condições de produção, matéria prima e mão-de-obra que se aproximam da serraria em estudo.

Assim, a partir dos levantamentos feitos por Barbosa (2003), tem-se:

Quadro 15: Consumo de energia nas serrarias de Itapeva e Itararé.

\begin{tabular}{|l|c|c|c|}
\hline & $\begin{array}{c}\text { Produção mensal } \\
\left(\mathbf{m}^{\mathbf{3}} \mathbf{)}\right.\end{array}$ & $\begin{array}{c}\text { Consumo de energia mensal } \\
\mathbf{( K W h )}\end{array}$ & $\begin{array}{c}\text { Consumo de energia } \\
\left(\mathbf{K W h} / \mathbf{~ m}^{\mathbf{3}} \mathbf{)}\right.\end{array}$ \\
\hline Serraria A & 760,00 & 17694,00 & 23,28 \\
\hline Serraria B & 2394,46 & $23.034,00$ & 9,61 \\
\hline Serraria C & 2034,00 & 33802,00 & 16,61 \\
\hline Serraria D & 777,00 & 13889,00 & 17,87 \\
\hline Serraria E & 2150,00 & 68742,00 & 31,97 \\
\hline Serraria F & 620,00 & 30530,00 & 49,24 \\
\hline Serraria G & 1600,00 & 57661,00 & 36,03 \\
\hline Média & & & 26,37 \\
\hline
\end{tabular}

Fonte: Adaptado de BARBOSA (2003).

Porém, como essas serrarias e a serraria do objeto de estudo possuem uma produção de madeiras de $1^{a}, 2^{a}$ e $3^{a}$ qualidades, será necessário fazer uma alocação da energia utilizada para cada produto. Segundo Barbosa (2003) as peças de $2^{\mathrm{a}}$ e $3^{\mathrm{a}}$ qualidades, provenientes do aproveitamento das costaneiras, possuem um maior consumo energético, pois para chegar à sua bitola final é necessário passar por mais máquinas do que as peças de $1^{\text {a }}$ qualidade, resultando em uma diferença no consumo de cada tipo de peça; assim a alocação não poderá ser feita pela relação direta de massa, necessitando utilizar um fator de correção. A autora faz então um levantamento do consumo de energia necessária para o desdobro das peças retiradas do bloco principal da tora (peças de $1^{\mathrm{a}}$ qualidade) e das peças retiradas do aproveitamento da costaneira (peças de $2^{\mathrm{a}}$ e $3^{\mathrm{a}}$ qualidades) de seis serrarias. 
Quadro 16: Consumo de energia por seção nas serrarias da região de Itapeva

\begin{tabular}{|l|l|c|c|}
\hline & \multicolumn{1}{|c|}{$\begin{array}{c}\text { Tipo de peça a ser } \\
\text { desdobrada }\end{array}$} & $\begin{array}{c}\text { Consumo de energia } \\
\text { por seção (KWh/m) }\end{array}$ & $\begin{array}{c}\text { Aumento de } \\
\text { consumo (\%) }\end{array}$ \\
\hline \multirow{2}{*}{ Serraria A } & Bloco principal & 0,033 & \multirow{2}{*}{38,05} \\
\cline { 2 - 3 } & Peça aprov. costaneira & 0,046 & \multirow{2}{*}{25,00} \\
\hline \multirow{2}{*}{ Serraria C } & Bloco principal & 0,012 & \multirow{2}{*}{12,90} \\
\cline { 2 - 3 } & Peça aprov. costaneira & 0,015 & \multirow{2}{*}{29,29} \\
\hline \multirow{2}{*}{ Serraria D } & Bloco principal & 0,018 & \\
\cline { 2 - 3 } & Peça aprov. costaneira & 0,021 & \multirow{2}{*}{20,10} \\
\hline \multirow{2}{*}{ Serraria F } & Bloco principal & 0,064 & 25,07 \\
\cline { 2 - 3 } & Peça aprov. costaneira & 0,083 & \multirow{2}{*}{0,055} \\
\hline \multirow{2}{*}{ Serraria G } & Bloco principal & 0,066 & \\
\cline { 2 - 3 } & Peça aprov. costaneira & & \\
\hline \multirow{2}{*}{ Média } & & & \\
\hline
\end{tabular}

Fonte: Adaptado de BARBOSA (2003).

Considerando os dados acima, tem-se que a porcentagem de consumo de energia para peças de reaproveitamento de costaneira é em média 25,07\% superior ao consumo do bloco principal e a média geral de consumo de energia é de $26,37 \mathrm{KWh}$ por $\mathrm{m}^{3}$ de madeira serrada.

- Operação de pré-fabricação: serão utilizadas as contas de energia elétrica da marcenaria para se fazer uma média da energia total gasta e então multiplicar pelos 2 meses e meio necessários para a usinagem das peças na pré-fabricação dos componentes (a etapa de pregação não utiliza nenhum equipamento elétrico e por isso não será incluída). Não será necessário fazer alocação do consumo de energia, visto que durante o período de usinagem das peças para os componentes pré-fabricados não foram feitas outras atividades concorrentes, e todo o consumo energético da marcenaria foi utilizado para esse fim.

- Operação de montagem: o consumo de energia elétrica foi calculado fazendo-se a divisão da potência dos equipamentos utilizados (furadeira elétrica de $500 \mathrm{~W}$ de potência) pelo tempo de uso (em média 10 minutos de funcionamento efetivo por habitação), dado registrado pela equipe de pesquisadores do Grupo Habis no acompanhamento dessa operação.

Além dos consumos de energia já citados acima, pode-se destacar o consumo de energia solar no processo de produção florestal (possibilitando a fotossíntese) e na secagem da madeira desdobrada (diminuindo o do teor de umidade da madeira), que não serão quantificados, mas serão analisados de forma qualitativa nos resultados finais. 


\section{IV) Bases referenciais para cálculo dos dados de emissões de poluições para o ar, solo e água.}

\section{- Emissão de poluentes para o ar}

Serão consideradas as emissões de poluentes dos processos elementares, pela queima de cavaco para geração de energia calorífica no processo de beneficiamento; e do transporte, proveniente da queima de combustíveis fósseis no transporte rodoviário entre os processos ou as etapas que ocorrem entre eles, e que é a principal fonte de emissões ao ar geradas na cadeia do ciclo de vida do sistema estrutural em madeira. O cálculo para quantificação das emissões foi feito a partir da lei $\mathrm{N}^{\circ}$ 8.723, de 28 de outubro de 1993, BRASIL (1993) que regulamenta as emissões máximas para veículos automotores produzidos ou comercializados no Brasil.

Quadro 17: Regulamentação de emissões máximas para veículos automotores.

\begin{tabular}{|l|c|c|c|}
\hline \multirow{2}{*}{} & \multirow{2}{*}{$\begin{array}{c}\text { Veículos leves } \\
\text { a partir de } 1997\end{array}$} & \multicolumn{2}{|c|}{ Veículos pesados (ciclo diesel) } \\
\cline { 3 - 4 } & A partir de 1996 & A partir de 2000 \\
\hline Monóxido de Carbomo (CO) & $2,0 \mathrm{~g} / \mathrm{Km}$ & $4,9 \mathrm{~g} / \mathrm{Km}$ & $4,0 \mathrm{~g} / \mathrm{KWh}$ \\
\hline Hidrocarboneto (HC) & $0,3 \mathrm{~g} / \mathrm{Km}$ & $1,23 \mathrm{~g} / \mathrm{Km}$ & $1,1 \mathrm{~g} / \mathrm{KWh}$ \\
\hline Óxidos de Nitrogênio (Nox) & $0,6 \mathrm{~g} / \mathrm{Km}$ & $9,0 \mathrm{~g} / \mathrm{Km}$ & $7,0 \mathrm{~g} / \mathrm{KWh}$ \\
\hline Aldeídeos (CHO) & $0,03 \mathrm{~g} / \mathrm{Km}$ & --- & --- \\
\hline \multirow{2}{*}{ Partículas } & $0,05 \mathrm{~g} / \mathrm{Km}$ & $0,7 \mathrm{~g} / \mathrm{KWh}^{*}$ & \multirow{2}{*}{$0,15 \mathrm{~g} / \mathrm{KWh}$} \\
\cline { 3 - 3 } & & $0,4 \mathrm{~g} / \mathrm{Km}^{* *}$ & \\
\hline
\end{tabular}

* para motores com até $85 \mathrm{KW}$ de potência.

** para motores com mais de $85 \mathrm{KW}$ de potência.

Fonte: adaptado de BRASIL (1993).

A resolução CONAMA número 315 de outubro de 2002 regulamenta a emissão de gases poluentes para veículos produzidos a partir do ano de 2007, porém será adotado o item I da lei $\mathrm{N}^{\circ} 8.723$, de 28 de outubro de 1993, pois era a regulamentação vigente na época do projeto e a frota utilizada foi produzida antes de 2000; além disso, apresenta um parâmetro mais crítico, com maiores fatores de emissão, não minimizando assim um item de grande impacto.

Os dados serão apresentados na matriz de coleta dos dados por processo e/ou etapa produtiva, na qual estarão expostas as emissões geradas por queima de combustíveis fósseis decorrente do transporte à montante do processo. Por exemplo, no processo de beneficiamento estarão inclusas as emissões do transporte da produção florestal (toras da floresta) até a serraria. Esses valores serão calculados a partir dos valores estipulados pela lei de emissão de gases e pela distância percorrida entre cada processo. 


\section{Cálculo das emissões de dióxido de carbono.}

Para o cálculo das emissões de dióxido de carbono será utilizado o método top-down, elaborado pelo IPCC (Intergovernmental Panel on Climate Change), aconselhado pelo MME (Ministério das Minas e Energia) em 2003 no Balanço Energético Nacional - BEN para estimar as emissões de GEE. O método, que está descrito abaixo, foi retirado de Macêdo (2004).

Primeiramente faz-se necessário a conversão de todas as medidas de consumo de combustíveis para uma unidade comum, e nesse caso foi adotado o tera-joule (1 TJ = $1012 \mathrm{~J})$. Para a conversão dos volumes consumidos dos combustíveis utiliza-se a equação 1.

$$
C C=C A \times F_{\text {conv }} \times\left(41,841 \times 10^{-3}\right) \times F_{\text {corr }}
$$

Onde:

$\mathrm{CC}=$ Consumo de energia em $\mathrm{TJ}$

$\mathrm{CA}=$ Consumo de combustível em $\mathrm{m}^{3}$

$\mathrm{F}_{\text {conv }}=$ Fator de conversão da unidade física de medida da quantidade de combustível para tonelada equivalente de petróleo (tEP*), com base no poder calorífico superior (PCS) do combustível

$1 \mathrm{tEP}=41,841 \times 10^{-3} \mathrm{TJ}($ téra-joule $=1012 \mathrm{~J})$

$\mathrm{F}_{\text {corr }}=$ Fator de correção de PCS para PCI (poder calorífico inferior)

Fonte: Macêdo (2004).

Serão adotados os valores dos $\mathrm{F}_{\text {conv }}$ de 2006, conforme o Anuário Estatístico da Agência Nacional do Petróleo (ANP. 2006) mostrados no quadro 19, pois não há referência bibliográfica para o ano de 2007.

Quadro 18: Valores dos $F_{\text {conv }}$ de 2006

\begin{tabular}{|c|c|}
\hline Combustível & Valor do $F_{\text {conv }}$ \\
\hline Gás Natural Seco e Úmido & $0,9361 \mathrm{tep} / 103 \mathrm{~m}^{3}$ \\
\hline Gasolina C e A & 0,75205 tep $/ \mathrm{m}^{3}$ \\
\hline Óleo Diesel & 0,88118 tep $/ \mathrm{m}^{3}$ \\
\hline Álcool Hidratado & 0,5097 tep $/ \mathrm{m}^{3}$ \\
\hline
\end{tabular}

Segundo o Balanço Energético Nacional, o conteúdo energético deve ter como base o PCS, mas o Intergovernmental Panel on Climate Change coloca que a conversão para unidade comum de energia deve ser feita pela multiplicação do consumo pelo PCI, sendo que para combustíveis 
sólidos e líquidos o $\mathrm{F}_{\text {corr }}=0,95$ e para combustíveis gasosos o $\mathrm{F}_{\text {corr }}=0,90$, conforme Ministério da Ciência e Tecnologia - MCT.

\section{Conteúdo de carbono}

A quantidade de carbono emitida na queima do combustível deve ser estimada conforme a equação 2:

$$
\mathrm{QC}=\mathrm{CC} \times \mathrm{F}_{\mathrm{emiss}} \times 10^{-3}
$$

Onde:

$\mathrm{QC}=$ Consumo de energia em $\mathrm{TJ}$

$\mathrm{F}_{\text {emiss }}=$ Fator de emissão de carbono em tonelada de carbono por téra-joule (tC/TJ)

$10^{-3}=\mathrm{tC} / \mathrm{GgC}$

Fonte: Macêdo (2004).

Os valores para o Femiss, segundo o IPCC (Intergovernmental Panel on Climate Change), 1996 e MCT (Ministério da Ciência e Tecnologia), 1999 são:

Quadro 19: Valores dos Femiss

\begin{tabular}{|l|c|}
\hline \multicolumn{1}{|c|}{ Combustível } & Valor do Fconv \\
\hline gasolina & $18,9 \mathrm{tC} / \mathrm{TJ}$ \\
\hline álcool anidro & $14,81 \mathrm{tC} / \mathrm{TJ}$ \\
\hline álcool hidratado & $14,81 \mathrm{tC} / \mathrm{TJ}$ \\
\hline diesel & $20,2 \mathrm{tC} / \mathrm{TJ}$ \\
\hline gás natural seco & $15,3 \mathrm{tC} / \mathrm{TJ}$ \\
\hline lenha & $29 \mathrm{tC} / \mathrm{TJ}$ \\
\hline \multicolumn{2}{|c|}{ Fonte: adaptado de Macêdo $(2004)}$.
\end{tabular}

Portanto, aplicando-se a equação 2 ao consumo total de energia relativa ao consumo total de combustíveis por fontes móveis no estado durante o período de estudo, tem-se o conteúdo total de carbono emitido em Giga grama de Carbono (GgC).

\section{Emissões reais de dióxido de carbono $\left(\mathrm{CO}_{2}\right)$}

A equação 3 será utilizada para calcular a quantidade real de emissões de CO2, considerando-se a relação entre as massas moleculares do Carbono (C) e do Dióxido de Carbono (CO2), onde 44 tCO2 equivale a $12 \mathrm{tC}$. 


$$
\mathrm{ECO}_{2}=\mathrm{QC} \times(44 / 12) \times 1.000
$$

Onde:

$\mathrm{ECO}_{2=}$ Emissões reais de dióxido de carbono em $\mathrm{tCO}_{2}$

$\mathrm{QC}=$ Conteúdo de carbono em $\mathrm{GgC}$

44/12= Conversão entre pesos moleculares

$1.000=1 \mathrm{GgCO}_{2}=1.000$ toneladas de Dióxido de Carbono

Fonte: Macêdo (2004).

Para aplicação do método no objeto de estudo serão utilizados os dados de consumo energético por combustíveis fósseis já descritos no item III- Bases referenciais para cálculo dos dados de uso de energia, cuja fonte foram as planilhas de levantamentos econômico, ambiental que estão no Anexo III. Para o caso das emissões ao ar geradas pela queima do cavaco de Pinus é necessária a adição de um fator de correção para a obtenção do total de carbono emitido, pois nem todo material é queimado, portanto nem todo carbono é oxidado e transformado em $\mathrm{CO}_{2}$, sendo que uma parte é transformada em cinzas, MAFRA et al (2006). Esse fator de correção é o fator de oxidação (entre 0 e 1), que representa a quantidade de material que será efetivamente oxidado. Segundo o IPCC (2004), o fator de oxidação é de 0,88 para lenhas em geral, segundo Mafra et al (2006), o fator é de 0,879 e Brand et al (2004) faz um levantamento mais preciso de cavacos de Pinus no Brasil, em função do tempo de armazenamento, conforme o quadro 20:

Quadro 20: Fator de oxidação, em função do tempo de armazenamento

\begin{tabular}{|l|c|c|c|c|}
\hline \multicolumn{5}{|c|}{ Material oxidado (entre 0 e 1) } \\
\hline & $\begin{array}{c}\text { Amostra } \\
\text { Recém chegada }\end{array}$ & 1 mês & 4 meses & 6 meses \\
\hline Cavaco de Pinus & 0.9912 & 0,986 & 0,9936 & 0,9167 \\
\hline
\end{tabular}

Como Brand utiliza um material mais próximo do objeto de estudo, cavaco de Pinus, em vez de lenha (que apresenta uma menor oxidação na queima) e trabalha dentro da realidade brasileira com uma importante variável não considerada pelos outros autores, o teor de umidade do cavaco, serão adotados os valores apresentados por este autor.

Como já foi explicado anteriormente, o cavaco será enquadrado na categoria amostra recém chegada, assim, seguindo as informações dos quadros acima, para cada metro estéril de toras de Pinus são produzidos 98,47 kg de cavaco, equivalentes a 152636,25 Kcal, e segundo ANP (2006) 1 tep $=10000$ Mcal, portanto para cada $1 \mathrm{~m}^{\text {st }}$ de tora tem-se 15,2636. $10^{-3}$ tep, ou $0,63864 \cdot 10^{-3} \mathrm{TJ}$. 
Utilizando-se o Femiss da lenha fornecido pelo IPCC, que é de $29 \mathrm{tC} / \mathrm{TJ}$, aplicado à equação 2, tem-se que o conteúdo de carbono emitido é igual a $0,185207 \times 10^{-6}$, expresso em gigagrama. Para correção do carbono oxidado utiliza-se o fator de oxidação $(0,9912)$ e a equação 3, chegando-se à conclusão que a emissão é de $67,31 \mathrm{~kg}$ de $\mathrm{CO}_{2}$ para $1 \mathrm{~m}^{\text {st }}$ de toras de Pinus.

Para todas as emissões de poluentes ao ar serão necessárias alocações que serão feitas pelo mesmo critério de massa dos produtos, apresentado anteriormente, já que a emissão dos caminhões é fixa por quilometragem (estabelecida por lei) e sua carga é variável. Por exemplo, se um caminhão com capacidade para $5 \mathrm{~m}^{3}$ de madeira emitir $100 \mathrm{~kg}$ de $\mathrm{CO}_{2}$ e estiver com a carga completa, então cada $\mathrm{m}^{3}$ de madeira teria uma emissão equivalente a $20 \mathrm{~kg}$ de $\mathrm{CO}_{2}$, porém se o caminhão estiver carregando somente $1 \mathrm{~m}^{3}$ de madeira, então a emissão seria de $100 \mathrm{~kg}$ por $\mathrm{m}^{3}$ de madeira.

No processo de produção florestal existe uma especificidade, a captura de dióxido de carbono devido à fotossíntese, não encontrada em nenhum outro processo desse ciclo de vida. Segundo a SOCIEDADE BRASILEIRA DE SILVICULTURA (2007) as florestas de Pinus no Brasil armazenam em média 8 toneladas carbono/ha/ano, valor que será utilizado para se calcular a massa real de $\mathrm{CO}_{2}$ resgatado, utilizando as equações já apresentadas.

\section{b) Emissão de poluentes para o solo e água.}

Não foram emitidos produtos com potencial tóxico para o solo e água, sendo detectadas somente emissões provenientes dos esgotos das partes administrativas, lançados na rede de esgoto pública ou em sistemas de fossa séptica e sumidouro. No processo de produção florestal o engenheiro responsável entrevistado disse não ter levantamentos das emissões ao solo, sendo nesse processo utilizada a revisão bibliográfica para essa análise. Nas operações de disposição final e de manutenção do sistema de cobertura está sendo considerada a disposição dos produtos contaminados com o tratamento preservativo à base de cipermetrina em aterros industriais devidamente preparados, pois as embalagens utilizadas e todo o sistema estrutural desmontado teriam um potencial tóxico para o solo e água, caso houvesse lixiviação do produto nesses meios.

Elucidada as bases de cálculo que serão utilizadas para estimar alguns valores não obtidos e calcular os dados brutos do inventário, foram levantados os dados do inventário, contidos nas planilhas de coleta de dados (ver anexo I), e calculados segundo cada categoria de impacto, etapa que será descrita no capítulo 4. 
Capítulo 4

\section{Avaliação dos impactos do ciclo de vida do sistema estrutural em VLP}

Nesse capítulo será feita a avaliação dos impactos do ciclo de vida, que envolve a associação de dados de inventário com impactos específicos. Essa fase inclui as seguintes etapas:

- seleção de categorias de impacto, indicadores de categoria e modelos de caracterização; identificação das categorias de impacto, indicadores de categorias e modelos de caracterização relacionados, ponto final da categoria e os resultados da ACV relacionados;

- correlação de dados de inventário por categorias de impacto (classificação);

- modelagem dos dados de inventário por categorias de impacto (caracterização);

- cálculo dos resultados dos impactos de categoria (caracterização).

A avaliação dos impactos do ciclo de vida no objeto de estudo será feita a partir dos dados levantados no inventário, mas a correlação dos dados por categorias de impacto não será feita, pois antes da coleta estes já foram divididos nas mesmas categorias que serão utilizadas na avaliação dos impactos. As etapas de modelagem e cálculo dos dados terão seus resultados apresentados nos itens 4.2 à 4.6 .

\subsection{Seleção das categorias de impacto e modelagem dos dados de inventário por categorias de impacto.}

As categorias de impacto serão divididas inicialmente seguindo a caracterização proposta para a sustentabilidade no capítulo 1, onde foram identificadas cinco dimensões da sustentabilidade: ambiental, social, econômica, política e cultural. Essas categorias serão subdivididas de acordo com os métodos já consolidados e normalizados no Brasil e as categorias de impacto relacionadas a esses métodos, para se criar uma base de dados confiável e passível de ser executada dentro da realidade que está inserida. Assim as classes de variáveis poderão ser divididas seguindo a proposta dos itens abaixo. 


\section{I) Categorias de impacto e modelagem dos dados da dimensão ambiental.}

O método de avaliação do ciclo de vida, adotado para a análise ambiental, é regulamentado pela ABNT (2004), que não define os indicadores ou as categorias que devem ser aplicadas para um estudo de impacto, mas coloca que cada estudo deve aplicar seus próprios indicadores de forma a garantir uma base comparativa confiável; assim, as categorias devem ser escolhidas segundo critérios que indiquem os fatores relevantes em cada experiência.

Para o presente trabalho, adotar-se-á critérios de avaliação de impactos ambientais já difundidos e amplamente utilizados e consolidados para garantir sua comparabilidade e confiabilidade. Em seu estudo, Silva, V. (2003) procura levantar e comparar as categorias de análise ambiental mais utilizadas nos métodos atuais, propondo então uma normalização que dividiria as categorias da seguinte forma:

- Estratégias de implantação

- Gestão do uso de água

- Gestão do uso de energia

- Gestão do uso de materiais e de resíduos

- Prevenção de poluição

- Gestão ambiental do processo

- Qualidade do ambiente interno

- Qualidade dos serviços

Serão adotados os indicadores propostos por SILVA, V. (2003), devido ao seu uso já difundido, à sua proposta de normalização e por atender os critérios, diretrizes e metas da sustentabilidade colocados anteriormente, porém serão considerados somente os indicadores aplicáveis ao estudo de um sistema estrutural, que são:

- Gestão do uso de água

- Gestão do uso de energia

- Gestão do uso de materiais e de resíduos

- Prevenção de poluição

Para a coleta de dados foram adotadas, respectivamente, as seguintes denominações:

- Uso de água

- Uso de energia

- Uso de matéria prima / geração de resíduos

- Emissões de poluições para o ar, solo e água. 
A avaliação será feita pela análise dos dados quantitativos e qualitativos de forma absoluta, ou seja, não serão criadas formas de ponderação como notas ou conceitos. Esses dados poderão então formar um banco de dados comparativos, onde os dados de cada categoria serão comparados de forma a permitir um reflexo mais próximo da realidade.

\section{II) Categorias de impacto e modelagem dos dados da dimensão social.}

As categorias de impacto da dimensão social serão as propostas pelos métodos de análise da responsabilidade social, criados pelo Instituto Ethos: o balanço social (utilizado para levantamento do inventário social) e o Indicadores Ethos de responsabilidade social. Ambos são compatíveis entre si, pois apresentam as mesmas categorias de impacto levantadas no inventário, possibilitando uma relação direta entre os dados levantados e essas categorias. O método de indicadores também é uma forma de simplificar e facilitar a comparabilidade dos dados qualitativos, vista a complexidade desse tipo de avaliação. As categorias de impacto (também chamadas de temas) que serão avaliadas e seus indicadores são apresentadas no quadro 21:

Quadro 21: Temas e indicadores da responsabilidade social.

\begin{tabular}{|l|l|}
\hline \multicolumn{1}{|c|}{ Temas } & \multicolumn{1}{c|}{ Indicadores } \\
\hline Diálogo e participação & relação com sindicatos / gestão participativa \\
\hline $\begin{array}{l}\text { Auto-regulação e } \\
\text { conduta }\end{array}$ & $\begin{array}{l}\text { compromissos éticos / enraizamento na cultura organizacional / governança } \\
\text { corporativa }\end{array}$ \\
\hline $\begin{array}{l}\text { Relações transparentes } \\
\text { com a sociedade }\end{array}$ & $\begin{array}{l}\text { relações com a concorrência / diálogo e engajamento das partes interessadas } \\
\text { / balanço social }\end{array}$ \\
\hline Respeito ao indivíduo & $\begin{array}{l}\text { compromisso com os direitos das crianças / valorização da diversidade e } \\
\text { promoção da eqüidade racial e de gênero / relações com trabalhadores } \\
\text { terceirizados }\end{array}$ \\
\hline Trabalho decente & $\begin{array}{l}\text { política de remuneração, benefícios e carreira / cuidados com saúde, } \\
\text { pegurança e condições de trabalho / compromisso com o desenvolvimento } \\
\text { profissional e a empregabilidade / comportamento frente a demissões / } \\
\text { preparação para aposentadoria }\end{array}$ \\
\hline $\begin{array}{l}\text { Seleção, avaliação e } \\
\text { parceria com os } \\
\text { fornecedores }\end{array}$ & $\begin{array}{l}\text { critérios de seleção e avaliação dos fornecedores / trabalho infantil na cadeia } \\
\text { produtiva / trabalho forçado na cadeia produtiva / apoio ao } \\
\text { desenvolvimento dos fornecedores }\end{array}$ \\
\hline $\begin{array}{l}\text { Dimensão social do } \\
\text { consumo }\end{array}$ & $\begin{array}{l}\text { política de comunicação comercial / excelência do atendimento / } \\
\text { conhecimento e gerenciamento dos danos potenciais de produtos e serviços }\end{array}$ \\
\hline $\begin{array}{l}\text { Relações com a } \\
\text { comunidade local }\end{array}$ & $\begin{array}{l}\text { gerenciamento do impacto na comunidade de entorno e relacionamento com } \\
\text { organizações locais / envolvimento e financiamento da ação social }\end{array}$ \\
\hline Ação social & financiamento da ação social / envolvimento com a ação social \\
\hline Transparência política & $\begin{array}{l}\text { contribuições para campanhas políticas / construção da cidadania pelas } \\
\text { empresas / práticas anticorrupção e antipropina }\end{array}$ \\
\hline Liderança social & $\begin{array}{l}\text { liderança e influência social / participação em projetos sociais } \\
\text { governamentais }\end{array}$ \\
\hline
\end{tabular}

Fonte: adaptado de Custodio, A. L. de M.; Moya, R (2007) 
O método de análise por indicadores ainda é dividido em duas partes, uma aplicável para grandes e médias empresas, e outra para pequenas e micro empresas, com diferentes graus de exigência que cada tipo de empresa deve atender para ficar dentro de um determinado nível de desempenho social. Segue abaixo um exemplo dos indicadores que serão aplicados no método Indicadores Ethos (grandes e médias empresas) e no método Indicadores Ethos-SEBRAE (pequenas e micro empresas).

\begin{tabular}{|c|c|c|}
\hline \multicolumn{3}{|c|}{ Valores, Transparência e Governança } \\
\hline \multicolumn{3}{|c|}{ Auto-regulação da conduta } \\
\hline Indicador 2 & \multicolumn{2}{|l|}{ Enraizamento na Cultura Organizacional } \\
\hline \multicolumn{3}{|c|}{ Com relação à eficácia na disseminação dos valores e princípios éticos da empresa: } \\
\hline \multicolumn{3}{|c|}{$\begin{array}{l}\text { Estágio 1: Os valores e princípios são transmitidos ao público interno esporadicamente ou em } \\
\text { momentos específicos (como na contratação de empregados ou em processos de auditoria). }\end{array}$} \\
\hline \multicolumn{3}{|c|}{ Estágio 2: Há processos sistemáticos de difusão dos valores e princípios para o público interno. } \\
\hline \multicolumn{3}{|c|}{$\begin{array}{l}\text { Estágio 3: Além disso, a adoção desses valores e princípios é auditada e verificada } \\
\text { periodicamente e os empregados são estimulados a contribuir com o monitoramento do } \\
\text { processo. }\end{array}$} \\
\hline \multicolumn{3}{|c|}{$\begin{array}{l}\text { Estágio 4: Além disso, todos os parceiros externos são estimulados a replicar esse processo na } \\
\text { cadeia produtiva. }\end{array}$} \\
\hline \multicolumn{3}{|c|}{ Não vemos aplicação disso em nossa empresa (justifique). } \\
\hline \multicolumn{3}{|c|}{ Não havíamos tratado antes desse assunto. } \\
\hline \multicolumn{3}{|c|}{ Informações adicionais: } \\
\hline \multicolumn{3}{|c|}{$\begin{array}{l}\text { 2.1. questões éticas são abordadas em pesquisas de clima organizacional, por avaliação } \\
360 \text { graus ou ferramentas similares. }\end{array}$} \\
\hline \multicolumn{2}{|c|}{$\begin{array}{l}\text { 2.2. os empregados da empresa demonstram familiaridade no seu dia-a-dia com os } \\
\text { temas e pressupostos contemplados no código de conduta, aplicando-os } \\
\text { espontaneamente. }\end{array}$} & \\
\hline \multicolumn{2}{|c|}{$\begin{array}{l}\text { 2.3. a estrutura organizacional desenvolveu procedimentos para lidar com denúncias e } \\
\text { resolução de conflitos relacionados ao desrespeito ao seu código de conduta ou à sua } \\
\text { declaração de valores. }\end{array}$} & \\
\hline
\end{tabular}

Figura 27: Adaptado de parte de uma planilha de coleta de dados referente à dimensão social no processo 2. Fonte: adaptado de Custodio, A. L. de M.; Moya, R (2007). 


\begin{tabular}{|c|c|c|c|c|c|}
\hline \multicolumn{5}{|c|}{ Público Interno } & \multirow{2}{*}{9} \\
\hline Indicador 9 & \multicolumn{4}{|l|}{ Compromissos Éticos } & \\
\hline \multirow{5}{*}{\multicolumn{2}{|c|}{$\begin{array}{l}\text { Os critérios utilizados na seleção de pessoal } \\
\text { são isentos de práticas discriminatórias em } \\
\text { relação a quaisquer dos temas: gênero, raça, } \\
\text { orientação sexual, idade e crenças religiosas } \\
\text { ou políticas, bem como portadores de } \\
\text { deficiência? }\end{array}$}} & \multicolumn{4}{|l|}{ Sim } \\
\hline & & \multicolumn{4}{|c|}{ Em grande parte } \\
\hline & & \multicolumn{4}{|c|}{ Em parte } \\
\hline & & \\
\hline & & \multicolumn{4}{|c|}{$\begin{array}{l}\text { Não vemos aplicação disso em nossa empresa } \\
\text { (justifique) }\end{array}$} \\
\hline & & & Sim & Não & NA \\
\hline \multicolumn{6}{|c|}{$\begin{array}{l}\text { 9.1. Ao divulgar vagas a empresa não utiliza termos como "idade } \\
\text { máxima } 40 \text { anos", "boa aparência", "sexo masculino", "sexo } \\
\text { feminino", etc.? }\end{array}$} \\
\hline \multicolumn{6}{|l|}{ A empresa: } \\
\hline \multicolumn{6}{|c|}{ 9.2. oferece oportunidades de trabalho para ex-detentos? } \\
\hline \multicolumn{6}{|c|}{ 9.3. mantém programa especial para contratação de idosos? } \\
\hline \multicolumn{3}{|c|}{$\begin{array}{l}\text { 9.4. disponibiliza vagas para programas e atividades que visam } \\
\text { fortalecer os direitos dos adolescentes? }\end{array}$} & & & \\
\hline
\end{tabular}

Figura 28: Adaptado dos indicadores Ethos-SEBRAE para micro e pequenas empresas. Fonte: Adaptado de CUSTODIO, A. L. de M.; MOYA, R (2007)

Para efetuar a avaliação final é feita uma ponderação com as respostas adquiridas no levantamento e que são pontuadas da seguinte maneira:

\section{Cálculo da pontuação para Indicadores Ethos (grandes e médias empresas)}

- Cada tema vale 300 pontos;

- Cada indicador de profundidade vale 300 dividido pelo número de indicadores do tema, onde o estágio 1 vale $1 / 4$ do valor do indicador, o estágio 2 vale $2 / 4$, o estágio 3 vale $3 / 4$ e o estágio 4, o valor integral do indicador.

- Os indicadores binários valem 45 pontos por tema. Cada indicador binário vale 45 pontos dividido pelo número de indicadores binários de cada tema. Ao incluir os binários dos setoriais (quando necessário) esses entram nessa soma.

- Portanto, como são sete temas, o valor total dos indicadores de profundidade é igual a 7 vezes 300 pontos, ou 2100 pontos.

- Os indicadores binários valem, ao todo, sete vezes 45 pontos, ou 315 pontos.

- Somados 2100 mais 315 pontos, chega-se à pontuação máxima de 2415 pontos, que, por regra de três, pode ser equivalente à nota dez.

Cálculo de pontuação para Indicadores Ethos-Sebrae (pequenas e micro empresas). 
Para o Ethos-Sebrae os valores dos indicadores são dados em porcentagens, sendo $10 \%$ para “Não", 40\% para "Em parte", 70\% para "Em grande parte" e 100\% para "Sim".

A pontuação máxima do tema continua sendo 300 pontos $+15 \%=345$ pontos e o valor máximo do indicador é de 300 dividido pela quantidade de indicadores do tema $+15 \%$. Veja o exemplo abaixo:

Se para o tema "Valores, Transparência e Governança" tem-se 5 indicadores, então a pontuação de cada indicador valerá 300/5, ou seja, 60 pontos. Assim, a resposta "Não" (10\% de 60 pontos) vale 6 pontos, "Em parte" (40\%), 24 pontos e assim por diante, acrescentando-se ainda o fator de até $15 \%$ dos indicadores binários que seguem a mesma regra dos Ethos Geral.

A nota final do tema será a soma das pontuações de todos os seus indicadores, obtida na escala de 0 a 345, e em seguida é necessário se fazer a conversão para escala de 0 a 10, com regra de 3 simples.

\section{III) Categorias de impacto e modelagem dos dados da dimensão econômica.}

A dimensão econômica seguirá as mesmas categorias propostas pelo método elaborado pelo instituto Ethos, que foram utilizadas para as coletas de dados e são:

- Produtividade;

- Investimentos;

- Distribuição de riquezas.

Assim como na dimensão ambiental, esses dados, quantitativos e qualitativos, serão analisados de forma absoluta para se chegar a um resultado mais próximo à realidade, além da análise qualitativa de algumas questões.

\section{IV) Categorias de impacto e modelagem dos dados da dimensão política.}

A dimensão política também seguirá as mesmas categorias propostas para a coleta de dados do inventário, que foram retiradas das metas e diretrizes da sustentabilidade pluridimensional, levantadas por Yuba (2005), Silva, S. (2000) e Sachs (1993) e já apresentadas no capítulo 1. As categorias propostas são:

- Organização das partes interessadas para conquista da participação ativa nas decisões: representação equilibrada; cooperação dentro do setor; terminologia consensual. 
- Valores organizacionais: apoio à liberdade de associação.

- Cooperação para desenvolvimento de construções mais sustentáveis: implementação de ações de pesquisa e desenvolvimento; parcerias com instituições de pesquisa.

- Monitoramento e avaliação da própria empresa: relatório de responsabilidade social; processo de certificação; coleta de informações para monitoramento.

A forma de avaliação será através de uma análise qualitativa dos dados e questões levantadas durante o inventário.

\section{V) Categorias de impacto e modelagem dos dados da dimensão política.}

A dimensão política também seguirá as categorias propostas para a coleta de dados do inventário e seguirá a proposição de inclusão das variáveis levantadas pelos autores já citados nos itens da dimensão política, visto que nenhuma das duas dimensões possui métodos para sua análise. Assim as categorias que serão levantadas são:

- Reavaliação do tradicional: resgate do trabalho em mutirão; adequação das técnicas mais sustentáveis ao contexto moderno.

- Superação da resistência aos materiais e técnicas mais sustentáveis: viabilidade dos materiais e técnicas mais sustentáveis para aumentar a confiança dos usuários.

- Recuperação de valores éticos para o planejamento da construção e assentamento.

- Internalização da sustentabilidade: aumento da percepção dos usuários para as questões da sustentabilidade; abandono da idéia de sustentabilidade apenas como mais uma variável dentro do empreendimento.

Assim como na dimensão política, a avaliação será feita através de uma análise qualitativa dos dados e questões levantadas durante o inventário.

Estabelecido sobre quais categorias de impacto o trabalho se pautará, serão apresentados nos próximos itens os dados coletados dentro de cada categoria de impacto listada no item anterior, facilitando assim a análise no capítulo 5. A correlação de dados do inventário com as categorias de impacto, sua modelação e cálculo, resultam nos dados já caracterizados para cada processo ou operação do ciclo de vida - etapa que seguirá as bases de cálculos referenciais já apresentadas no capítulo 3.

Para apresentação dos dados quantitativos serão utilizadas tabelas e gráficos, e para os qualitativos serão utilizados os indicadores e a ponderação propostos pelo método de 
responsabilidade social empresarial para a dimensão social, além de um resumo apresentado em forma de texto, visto que a ponderação pode não expressar toda a complexidade da realidade dessa dimensão. Para os levantamentos qualitativos das demais dimensões, os dados serão apresentados em forma de textos divididos nas respectivas classes de variáveis, visto que ainda não existem métodos ou propostas consagradas para indicadores nessas dimensões. Ressalta-se aqui que todos os dados apresentados a seguir foram retirados das planilhas de coleta de dados, que estão no anexo I, acrescentando-se os cálculos necessários para a apresentação em forma resumida de gráficos e tabelas.

\subsection{Apresentação dos dados referentes à dimensão ambiental.}

A apresentação dos dados da dimensão ambiental seguirá a divisão de categorias propostas anteriormente: entradas de matéria prima e geração de resíduos: uso de água, uso de energia, emissão de poluentes para o ar, água e solo.

\subsubsection{Entradas das matérias primas e geração de resíduos.}

Nas entradas de matéria prima e geração de resíduos os dados serão apresentados para um fluxo referencial $\left(2,86 \mathrm{~m}^{3}\right.$ de estrutura montada no assentamento rural Pirituba II por 50 anos) em forma de gráficos e tabelas para se formar uma base comparativa numérica com os dados quantitativos. Deve-se ressaltar que foram consideradas como entradas de matéria prima somente os fluxos de produtos e fluxos elementares, não sendo computados os produtos intermediários, por não incorporarem mais matérias primas do meio ambiente em seu processo.

As entradas do processo florestal de mudas e área de solo necessárias não foram transformadas em quilos, pois os dados de massa das mudas não foram fornecidos na entrevista, e o solo é uma matéria prima com composição muito heterogenia e abundante, sendo mais relevante neste estudo quantificar a área necessária para o plantio das mudas.

No quadro 22 nota-se que existe um valor negativo no consumo de matéria prima durante o processo de produção florestal, o que indica um aumento de massa durante o processo, sendo nesse caso devido ao crescimento das mudas plantadas. O valor negativo nessa operação será analisado como um potencial de produção de matéria prima renovável dentro do ciclo de vida. 
Quadro 22: Uso de matéria prima ao longo do ciclo de vida do sistema estrutural em VLP.

\begin{tabular}{|c|c|c|c|c|c|}
\hline & & \multicolumn{4}{|c|}{ Uso de matéria prima } \\
\hline & & \multicolumn{4}{|c|}{ Para 1 fluxo referencial $=2,86 \mathrm{~m}^{3}$ de sist. montado } \\
\hline Processos & Operações & \multicolumn{2}{|c|}{ Fontes renováveis } & \multicolumn{2}{|c|}{ Fontes não renováveis } \\
\hline \multirow{5}{*}{$\begin{array}{l}\text { Produção } \\
\text { Florestal }\end{array}$} & & $63 *$ & $\begin{array}{l}\text { mudas de Pinus } \\
\text { Caribea var. } \\
\text { hondurensis }\end{array}$ & 0,13 & kg de herbicida \\
\hline & & $0,04^{*}$ & ha de solo & 0,04 & $\mathrm{~kg}$ de formicida \\
\hline & & $-4708,00 * *$ & kg toras de Pinus & 0,009 & kg cupinicida \\
\hline & & & & 11,15 & kg de adubo (fosf.) \\
\hline & & & & 0,89 & kg de formicida \\
\hline \multirow{2}{*}{$\begin{array}{l}\text { Beneficiamento } \\
\text { da madeira }\end{array}$} & Desdobro & & & 0,12 & kg quelato de cobre \\
\hline & Secagem & & & & \\
\hline \multirow{9}{*}{ Construção } & Pré-fabricação & & & 22,28 & kg aço (pregos) \\
\hline & \multirow{2}{*}{ Montagem } & 93,35 & kg de eucalipto & & \\
\hline & & & & 5,32 & kg aço (pregos) \\
\hline & Trat. preservativo & & & 0,017 & kg de cipermetrina \\
\hline & Uso & & & & \\
\hline & Manutenção/50anos & & & 0,14 & kg de cipermetrina \\
\hline & Desconstrução & & & & \\
\hline & Total por categoria & $-4614,65$ & $\mathrm{~kg}$ & 27,88 & $\mathrm{~kg}$ \\
\hline & & & Total geral & -4587 & $\mathrm{~kg}$ \\
\hline
\end{tabular}

\footnotetext{
* Entradas não transformadas em quilos pois os dados de massa das mudas não foram fornecidos na entrevista, e o solo é uma matéria prima abundante, sendo mais relevante neste estudo quantificar a área necessária para o plantio das mudas.

** Valor negativo no consumo de matéria prima indica um aumento de massa durante o processo, sendo nesse caso devido ao crescimento das mudas plantadas. O valor negativo nessa operação será analisado como um potencial de produção de matéria prima renovável dentro do ciclo de vida.
}

Fonte: Autor.

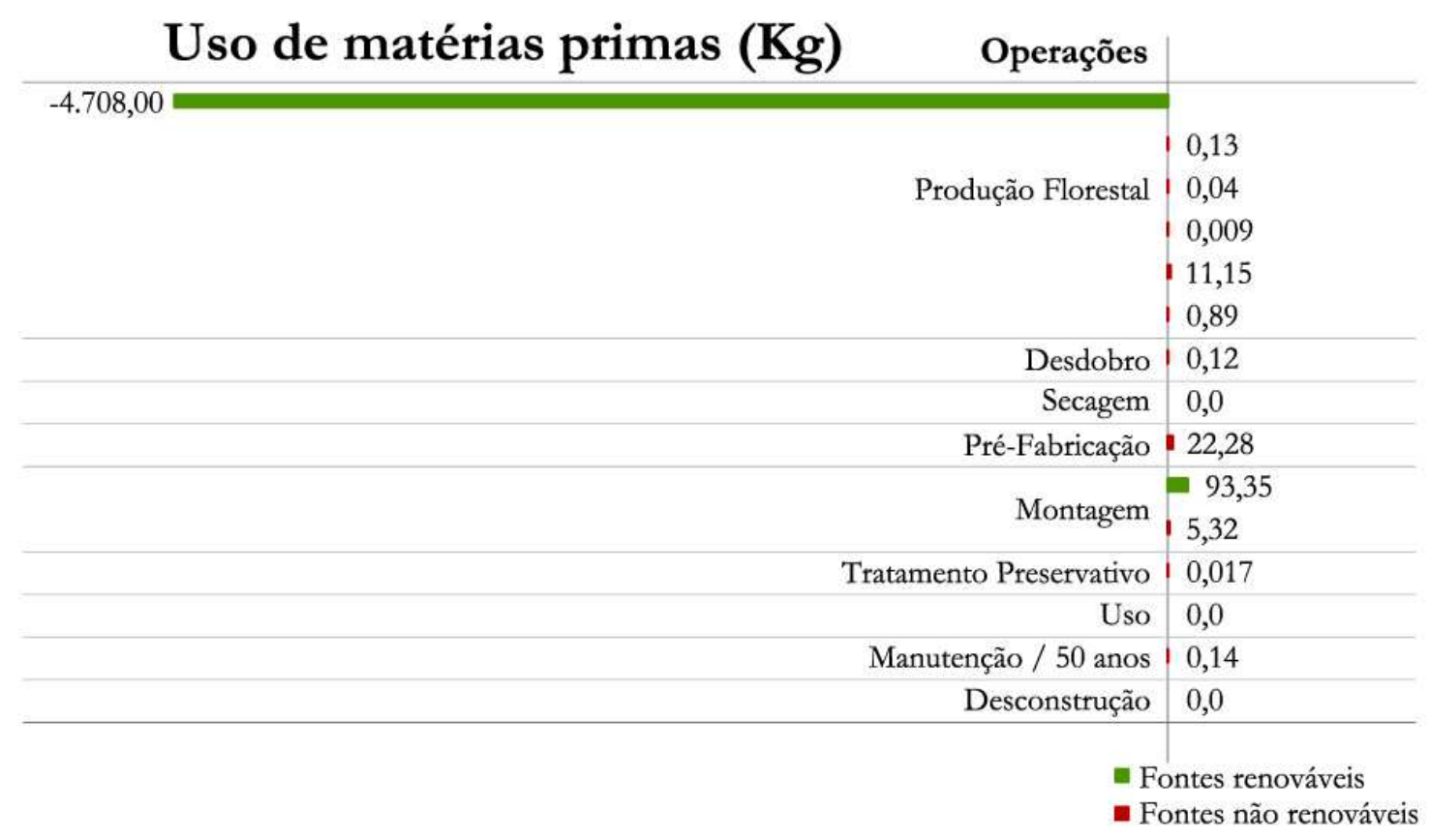

Figura 29: Gráfico do uso de matérias primas no ciclo de vida do sistema estrutural em VLP.

Fonte: Autor. 
Quadro 23: Geração de resíduos ao longo do ciclo de vida do sistema estrutural em VLP.

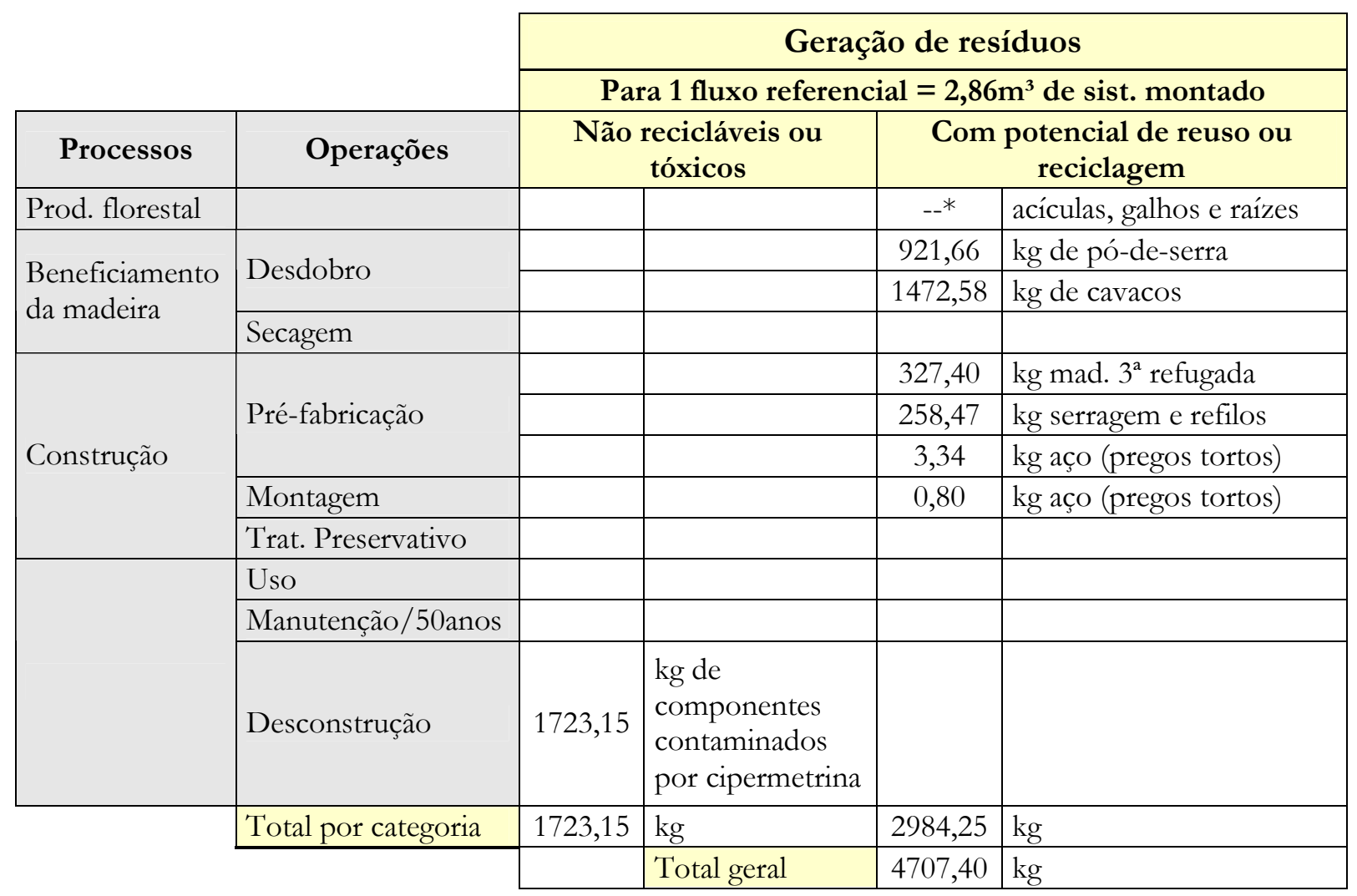

* Valor não quantificado devido ao não fornecimento dos dados na entrevista. Esses resíduos gerados poderão ser analisados de forma qualitativa, pois são decompostos diretamente no solo, servindo para repor seus nutrientes e não causando impactos ambientais por emissão ou poluição.

Fonte: Autor.

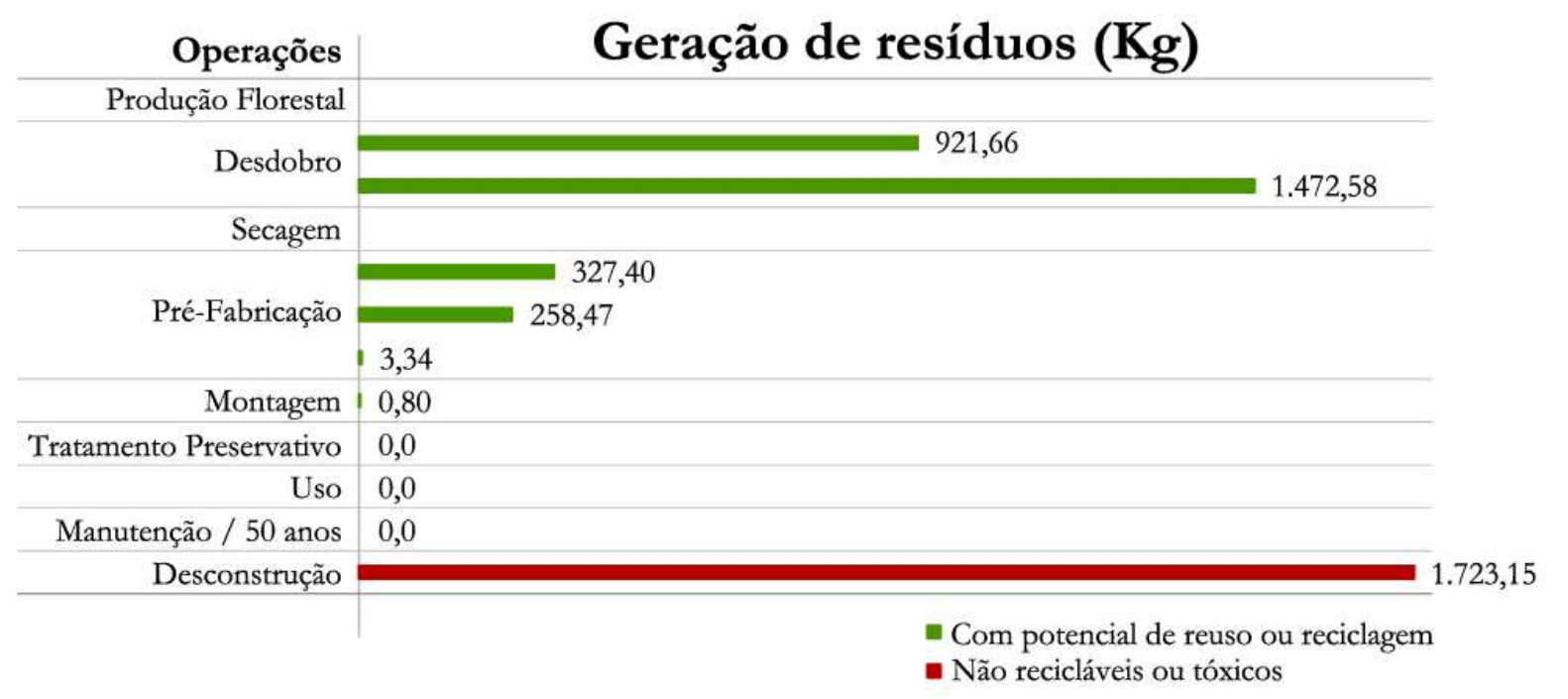

Figura 30: Gráfico da geração de resíduos no ciclo de vida do sistema estrutural em VLP.

Fonte: Autor. 
Destaca-se aqui que os $1472,58 \mathrm{~kg}$ e $921,66 \mathrm{~kg}$ de resíduos com potencial de reuso gerados na operação de desdobro das toras são referentes aos cavacos e serragem de madeira, que são subprodutos vendidos para geração de energia e forragem de animais e adubo, respectivamente.

\subsubsection{Uso de água.}

Deve-se destacar que o consumo de água levantado é referente ao consumo diretamente ligado à produção do sistema construtivo e seu beneficiamento, sem incluir consumos pessoais dos trabalhadores envolvidos ou das áreas administrativas.

Quadro 24: Consumo de água ao longo do ciclo de vida do sistema estrutural em VLP.

\begin{tabular}{|c|c|c|c|}
\hline & \multirow{2}{*}{\multicolumn{2}{|c|}{$\begin{array}{c}\text { Consumo de água } \\
\text { Para } 1 \text { fluxo referencial }=2,86 \mathrm{~m}^{3} \text { de sist. } \text { montado }\end{array}$}} \\
\hline \multirow{2}{*}{\begin{tabular}{|c|} 
Processos \\
Prod. Florestal \\
\end{tabular}} & \multirow[t]{2}{*}{ Operações } & & \\
\hline & & 3,72 & Litros de poço artesiano \\
\hline \multirow{2}{*}{$\begin{array}{l}\text { Beneficiamento } \\
\text { da madeira }\end{array}$} & Desdobro & 6,98 & Litros de poço artesiano \\
\hline & Secagem & & \\
\hline \multirow{7}{*}{ Construção } & Pré-fabricação & & \\
\hline & Montagem & & \\
\hline & Trat. preservativo & & \\
\hline & Uso & & \\
\hline & Manutenção/50anos & & \\
\hline & Desconstrução & & \\
\hline & Total & 10,70 & Litros de poço artesiano \\
\hline
\end{tabular}

Fonte: Autor.

\begin{tabular}{r|l} 
Operações & Consumo de água (L) \\
\hline Produção Florestal & \multicolumn{2}{|c}{6,98} \\
\hline Desdobro & \\
\hline Secagem & 0,0 \\
\hline Pré-Fabricação & 0,0 \\
\hline Montagem & 0,0 \\
\hline Tratamento Preservativo & 0,0 \\
\hline Uso & 0,0 \\
\hline Manutenção / 50 anos & 0,0 \\
\hline Desconstrução & 0,0 \\
\hline &
\end{tabular}

Figura 31: Gráfico de consumo de água no ciclo de vida do sistema estrutural em VLP.

Fonte: Autor. 


\subsubsection{Uso de energia.}

O cavaco (subproduto do desdobro da madeira) é vendido como fonte energética para outras indústrias, entrando no cálculo geral de uso de energia como um ganho (produção de energia) no consumo de energia calorífica, representado na tabela e no gráfico pelo sinal negativo ( - ).

Quadro 25: Consumo de energia ao longo do ciclo de vida do sistema estrutural em VLP.

\begin{tabular}{|c|c|c|c|}
\hline \multirow[b]{3}{*}{ Processos } & \multirow[b]{3}{*}{ Operações } & \multicolumn{2}{|c|}{ Consumo de energia em KWh } \\
\hline & & \multicolumn{2}{|c|}{ Para 1 fluxo referencial $=2,86 \mathrm{~m}^{3}$ de sist. montado } \\
\hline & & Elétrica & $\begin{array}{l}\text { Calorífica (comb. } \\
\text { fósseis e madeira) }\end{array}$ \\
\hline Prod. florestal & & & 0,31 \\
\hline \multirow{3}{*}{$\begin{array}{l}\text { Beneficiamento da } \\
\text { madeira }\end{array}$} & \multirow{2}{*}{ Desdobro } & \multirow{2}{*}{114,34} & $-2645,79$ \\
\hline & & & 0,16 \\
\hline & Secagem & & \\
\hline \multirow{6}{*}{ Construção } & Pré-fabricação & 23,94 & 0,02 \\
\hline & Montagem & 0,08 & 0,04 \\
\hline & Trat. Preservativo & & \\
\hline & Uso & & \\
\hline & Manutenção/50anos & & 0,07 \\
\hline & Desconstrução & & 2,43 \\
\hline & Total por categoria & 138,36 & $-2642,75$ \\
\hline & & Total geral & $-2504,39$ \\
\hline
\end{tabular}

Fonte: Autor

\section{Consumo de energia (KWh)}

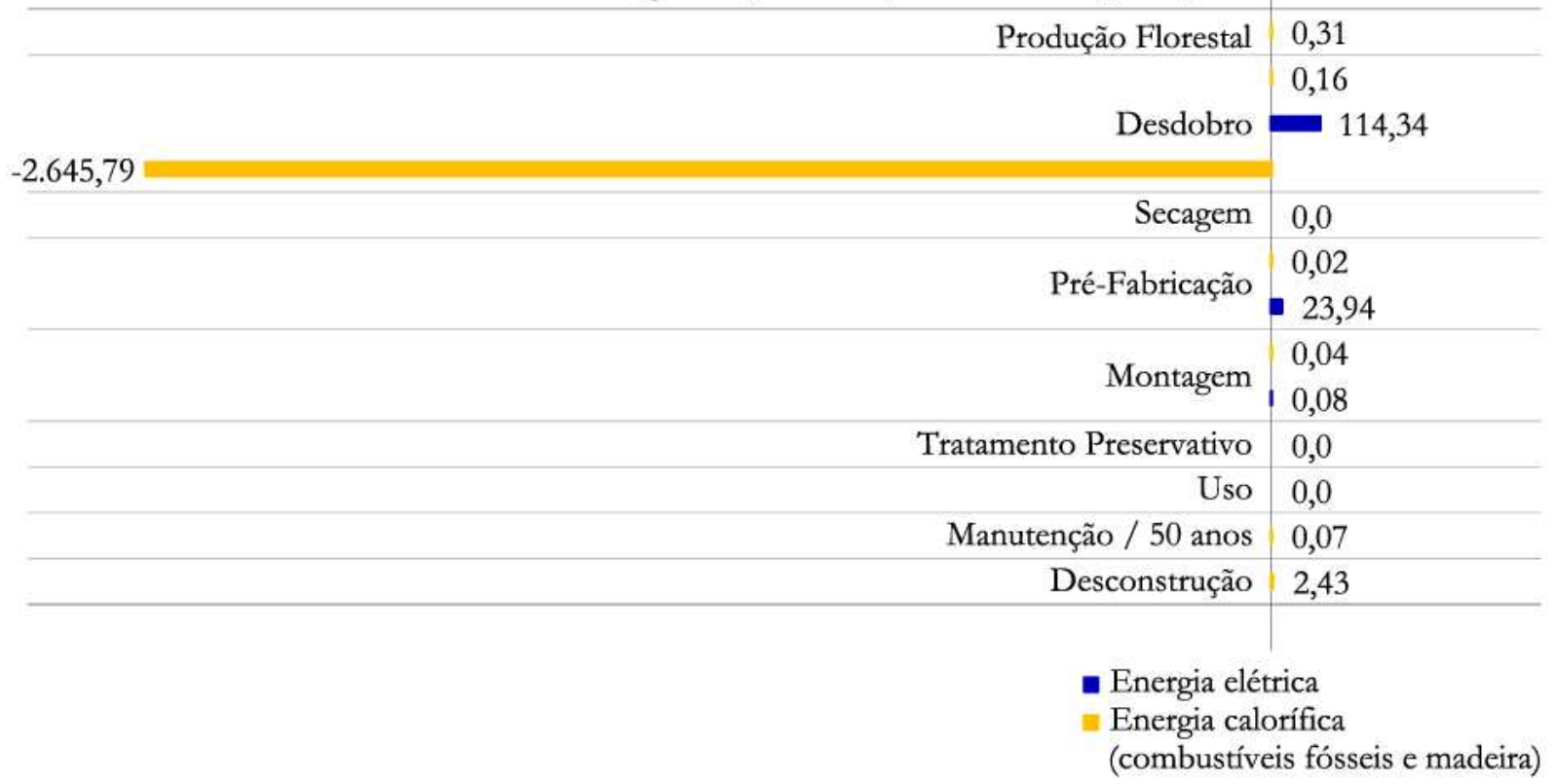

Figura 32: Gráfico de consumo de energia no ciclo de vida do sistema estrutural em VLP.

Fonte: Autor. 


\subsubsection{Emissão de poluentes ao ar, solo e água.}

Nos processos envolvidos nesse sistema do produto as emissões para o solo são somente as provenientes dos esgotos das áreas administrativas, que no entanto passam pelo sistema de fossa séptica e sumidouro, não havendo também contaminação das águas por essas ou outras emissões. $\mathrm{Na}$ operação de desconstrução foi considerada a disposição final dos produtos contaminados pela cipermetrina (embalagens e toda estrutura de madeira impregnada) em aterro industrial devidamente preparado (como recomendação do fabricante), para desconsiderar assim as possíveis emissões desses produtos tóxicos no solo, água ou ar.

As únicas fontes de emissão ao ar são as oriundas da queima de combustíveis fósseis do transporte da matéria prima, à montante de cada operação ou processo, e do transporte final da desconstrução, além da queima do cavaco no processo de beneficiamento da madeira, para geração de energia. 
Quadro 26: Emissão de poluentes para o ar ao longo do ciclo de vida do sistema estrutural em VLP.

Emissão de poluentes para o ar em gramas

Para 1 fluxo referencial $=2,86 \mathrm{~m}^{3}$ de sist. montado

\begin{tabular}{|l|l|c|c|c|c|}
\hline \multicolumn{1}{|c|}{ Processos } & \multicolumn{1}{|c|}{ Operações } & CO & HC & NOx & Partículas \\
\hline Prod. Florestal & & 49 & 11 & 92 & 6 \\
\hline \multirow{2}{*}{$\begin{array}{l}\text { Beneficiamento } \\
\text { da madeira }\end{array}$} & desdobro & 251 & 63 & 460 & 36 \\
\cline { 2 - 6 } & secagem & & & & \\
\hline \multirow{5}{*}{ Construção } & pré-fabricação & 64 & 16 & 118 & 9 \\
\cline { 2 - 6 } & montagem & 112 & 28 & 206 & 16 \\
\hline \multirow{5}{*}{} & Uso & & & & \\
\cline { 2 - 6 } & Manutenção/50anos & & & & 909 \\
\cline { 2 - 6 } & Desconstrução & 6362 & 1597 & 11686 & 976 \\
\hline
\end{tabular}

Fonte: Autor

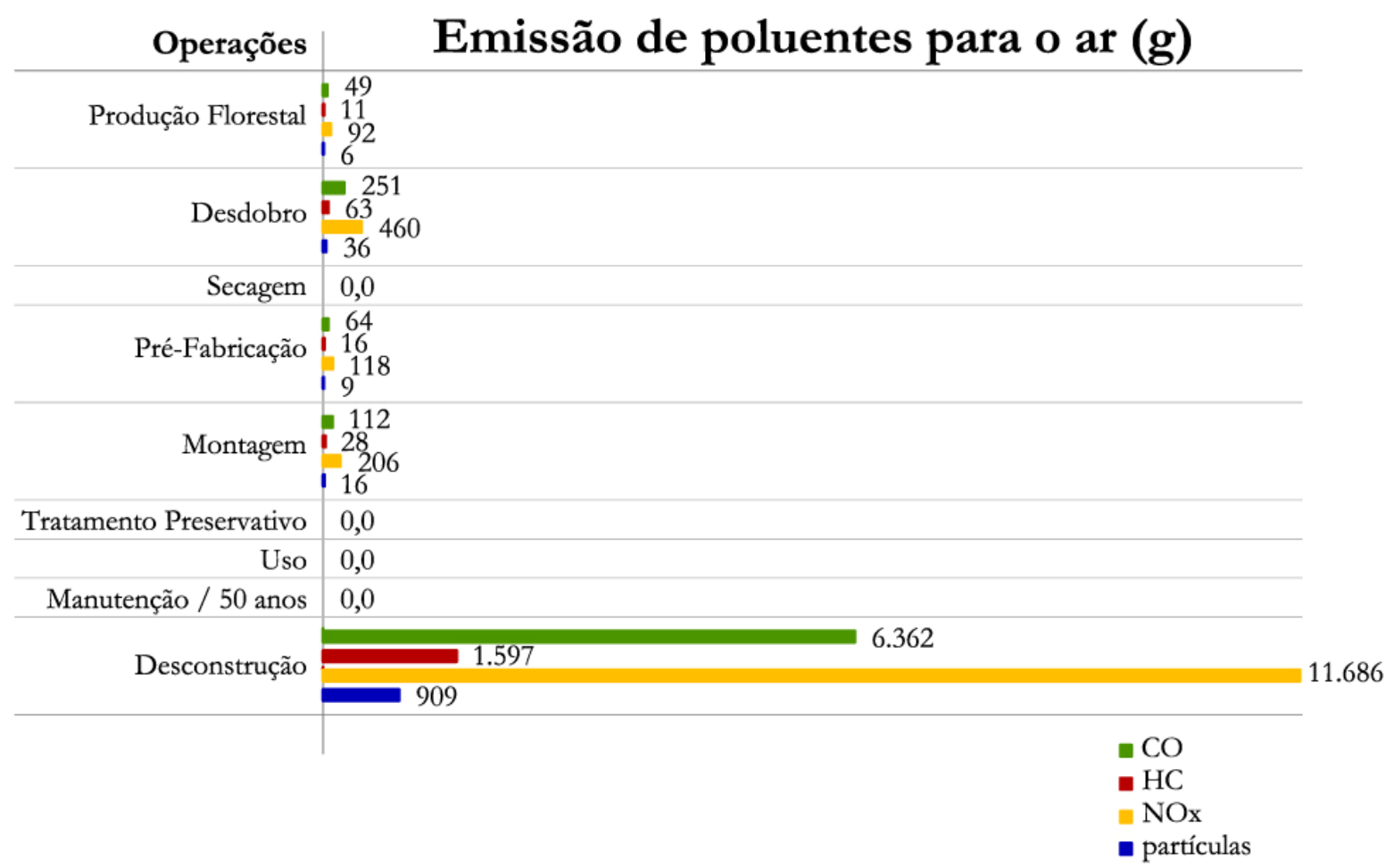

Figura 33: Gráfico de emissão de poluentes ao ar no ciclo de vida do sistema estrutural em VLP.

Fonte: Autor. 
Quadro 27: Emissão de CO2 ao longo do ciclo de vida do sistema estrutural em VLP.

\begin{tabular}{|c|c|c|}
\hline & Emissão de CO2 em kg \\
\hline & & $\begin{array}{c}\text { Para } 1 \text { fluxo referencial }=2,86 \mathrm{~m}^{3} \\
\text { de sist. Montado }\end{array}$ \\
\hline Processos & Operações & $\mathrm{CO} 2$ \\
\hline \multirow{2}{*}{ Prod. Florestal } & & 85,80 \\
\hline & & $-27264,38$ \\
\hline \multirow{3}{*}{$\begin{array}{l}\text { Beneficiamento da } \\
\text { madeira }\end{array}$} & \multirow{2}{*}{ Desdobro } & 1003,43 \\
\hline & & 76,45 \\
\hline & Secagem & \\
\hline \multirow{6}{*}{ Construção } & Pré-fabricação & 18,70 \\
\hline & Montagem & 32,55 \\
\hline & Trat. Preservativo & \\
\hline & Uso & \\
\hline & Manutenção/50anos & \\
\hline & Desconstrução & 1847,62 \\
\hline & Total & $-24199,83$ \\
\hline
\end{tabular}

Fonte: Autor.

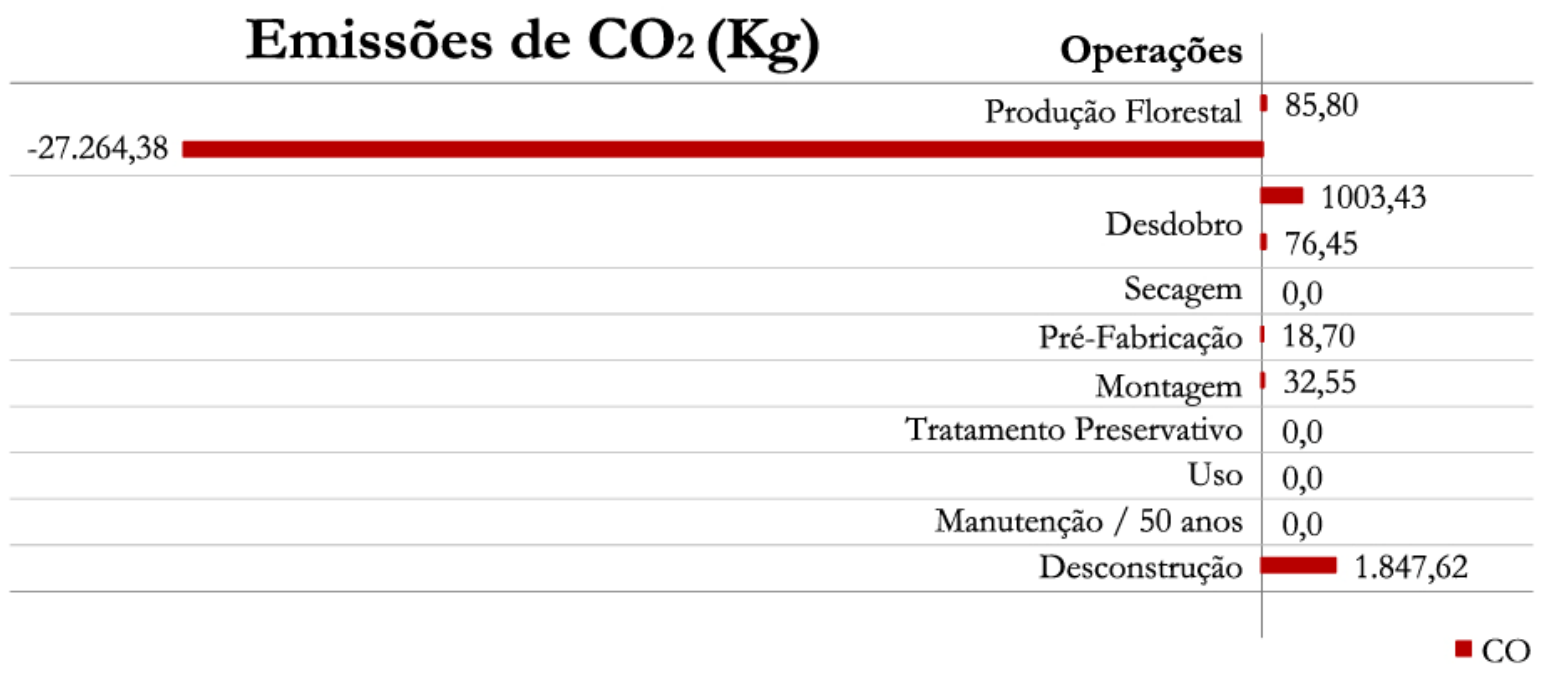

Figura 34: Gráfico de emissões de CO2 no ciclo de vida do sistema estrutural em VLP.

Fonte: Autor. 


\subsection{Apresentação dos dados da dimensão social.}

Os dados da dimensão social serão apresentados em forma de gráficos, para os resultados das ponderações feitas a partir dos indicadores aplicados (facilitando comparações); e através de textos, procurando incluir questões qualitativas de cada classe de variável previamente estipulada para essa dimensão, para que assim a simplificação da ponderação não encobrisse algumas questões mais complexas. Ressalta-se que todo o levantamento e os resultados obtidos, foram feitos para o nível organizacional e não para o do objeto, ou seja, a análise da sustentabilidade social é feita avaliando-se os agentes envolvidos na cadeia de produção (fornecedores, funcionários, proprietários, usuários, governo e sociedade envolvida) e não para o sistema estrutural propriamente dito.

Assim, considerando os agentes envolvidos: a empresa A (responsável pela produção florestal), a empresa Brancalhão (responsável pelo processo de beneficiamento das toras de Pinus spp) e a marcenaria coletiva e o mutirão autogerido (responsáveis pelo processo de construção do sistema estrutural de cobertura) será apresentado um gráfico comparativo das notas atingidas por cada um deles, a partir da ponderação dos indicadores aplicados, em relação aos atores: governo e sociedade, comunidade local, consumidores ou clientes, fornecedores, público interno (empregados ou trabalhadores) e em relação à classe de variável Valores internos e governança.

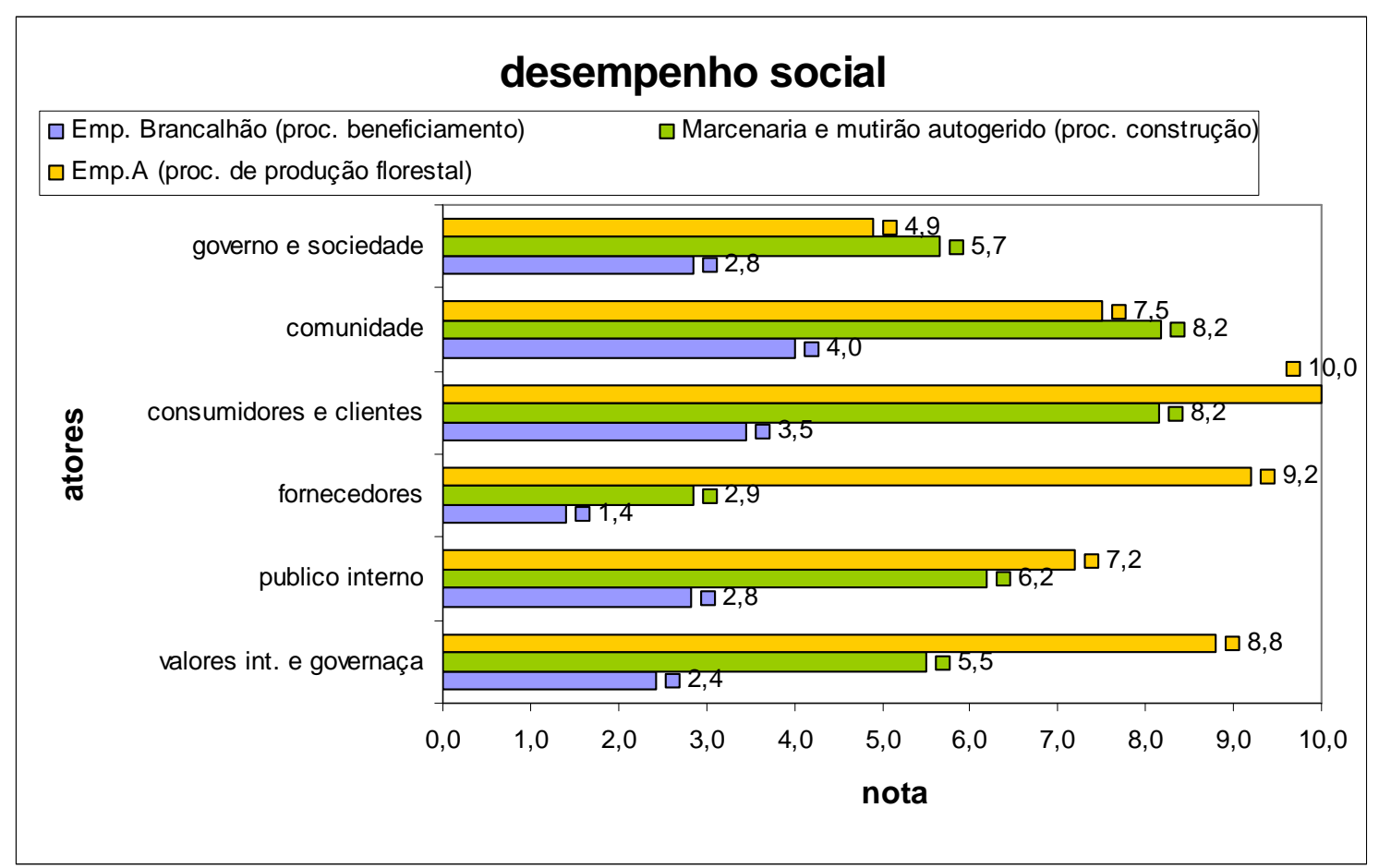

Figura 35: Desempenho social dos atores responsáveis pelos processos de produção florestal, beneficiamento da madeira e construção.

Fonte: Autor. 
As ponderações feitas para cada indicador serão apresentadas em um quadro, onde é possível verificar os melhores ou piores desempenho para determinado ator, deixando mais claro os pontos de ganhos e perdas de sustentabilidade. A pontuação é dividida em uma escala de 0 a $10 \mathrm{e}$ é aplicada a cada empreendimento do processo, que estão nas colunas. Nas linhas estão colocados os temas (publico interno, governo e sociedade, etc.) dentro dos quais estão seus indicadores, classificados por cores, como no quadro 28 abaixo.

Quadro 28: Pontuação dos empreendimentos do ciclo de vida do sistma estrutural de coberutra em VLP por temas e indicadores.

\begin{tabular}{|c|c|c|c|}
\hline \multicolumn{4}{|c|}{$\begin{array}{l}\text { Indicadores Ethos de Responsabilidade Social (para grandes e médias empresas) } \\
\text { Indicadores em comuns Ethos e Ethos - SEBRAE } \\
\text { Indicadores Ethos - SEBRAE de Responsabilidade Social (para pequenas e micro empresas) }\end{array}$} \\
\hline & $\begin{array}{c}\text { Processo de } \\
\text { Produção } \\
\text { Florestal } \\
\end{array}$ & $\begin{array}{c}\text { Processo de } \\
\text { Beneficiamento } \\
\text { da madeira } \\
\end{array}$ & $\begin{array}{l}\text { Processo de } \\
\text { Construção }\end{array}$ \\
\hline Valores, Transparência e Governança & 8,8 & 2,4 & 5,5 \\
\hline Enraizamento da cultura organizacional & 9,9 & 4,7 & \\
\hline Relações com a concorrência & 2,9 & 2,5 & \\
\hline Diálogo e engajamento das partes interessadas & 10,0 & 2,4 & \\
\hline Compromissos éticos & 8,0 & 4,7 & 10,0 \\
\hline Governança corporativa & 10,0 & 0,1 & 10,0 \\
\hline Balanço social & 9,9 & 3,2 & 5,3 \\
\hline Práticas anti-propina & & & 3,8 \\
\hline Práticas anti-corrupção & & & 0,9 \\
\hline & $\begin{array}{c}\text { Processo de } \\
\text { Produção } \\
\text { Florestal } \\
\end{array}$ & $\begin{array}{c}\text { Processo de } \\
\text { Beneficiamento } \\
\text { da madeira } \\
\end{array}$ & $\begin{array}{l}\text { Processo de } \\
\text { Construção }\end{array}$ \\
\hline Público interno & 7,2 & 2,9 & 6,2 \\
\hline Gestão participativa & 5,2 & 0,1 & \\
\hline Compromisso com o futuro das crianças & 10,0 & 2,5 & \\
\hline Compromisso com o desenvolvimento infantil & 4,7 & 2,7 & \\
\hline $\begin{array}{l}\text { Compromisso com a não discriminação e } \\
\text { equidade racial }\end{array}$ & 5,0 & 2,7 & \\
\hline Compromisso com a equidade de gênero & 5,0 & 3,5 & \\
\hline Relações com os trabalhadores terceirizados & 7,6 & 2,5 & \\
\hline Política de remuneração, benefícios e carreira & 7,3 & 2,7 & \\
\hline Comportamento nas demissões & 7,0 & 2,2 & \\
\hline Preparação para aposentadoria & 7,2 & 2,2 & \\
\hline Relação com sindicatos & 10,0 & 5,1 & 0,8 \\
\hline Valorização da diversidade & 5,4 & 2,5 & 10,0 \\
\hline $\begin{array}{l}\text { Cuidados com a saúde, segurança e condições } \\
\text { de trabalho }\end{array}$ & 7,2 & 6,9 & 8,2 \\
\hline $\begin{array}{l}\text { Compromisso com o desenvolvimento } \\
\text { profissional e empregabilidade }\end{array}$ & 9,8 & 2,2 & 10,0 \\
\hline Benefícios adicionais & & & 0,8 \\
\hline Critérios de contratação & & & 8,9 \\
\hline Inclusão de deficientes & & & 0,8 \\
\hline Acesso à informação & & & 10,0 \\
\hline
\end{tabular}




\begin{tabular}{|c|c|c|c|}
\hline & $\begin{array}{c}\text { Processo de } \\
\text { Produção } \\
\text { Florestal } \\
\end{array}$ & $\begin{array}{c}\text { Processo de } \\
\text { Beneficiamento } \\
\text { da madeira } \\
\end{array}$ & $\begin{array}{l}\text { Processo de } \\
\text { Construção }\end{array}$ \\
\hline Fornecedores & 9,2 & 2,8 & 2,8 \\
\hline Trabalho infantil na cadeia produtiva & 10,0 & 0,0 & \\
\hline $\begin{array}{l}\text { Trabalho forçado ou análogo ao escravo na } \\
\text { cadeia produtiva }\end{array}$ & 7,6 & 0,0 & \\
\hline Apoio ao desenvolvimento dos fornecedores & 8,9 & 2,7 & 3,7 \\
\hline Critérios de seleção e avaliação dos & 10,0 & 3,0 & 5,1 \\
\hline Empregados dos fornecedores & & & 1,4 \\
\hline \multirow[t]{2}{*}{ Responsabilidade social dos fornecedores } & & & 1,1 \\
\hline & $\begin{array}{c}\text { Processo de } \\
\text { Produção } \\
\text { Florestal }\end{array}$ & $\begin{array}{c}\text { Processo de } \\
\text { Beneficiamento } \\
\text { da madeira }\end{array}$ & $\begin{array}{l}\text { Processo de } \\
\text { Construção }\end{array}$ \\
\hline Consumidores e clientes & 10,0 & 3,5 & 8,1 \\
\hline Política de comunicação comercial & 10,0 & 2,7 & 10,0 \\
\hline Excelência no atendimento & 10,0 & 2,8 & 6,6 \\
\hline $\begin{array}{l}\text { Conhecimento e gerenciamento dos danos } \\
\text { potenciais dos produtos e serviços }\end{array}$ & 9,9 & 4,9 & 7,5 \\
\hline Dúvidas, sugestões e reclamações & & & 10,0 \\
\hline \multirow[t]{2}{*}{ Satisfação dos consumidores e clientes } & & & 7,0 \\
\hline & $\begin{array}{c}\text { Processo de } \\
\text { Produção } \\
\text { Florestal }\end{array}$ & $\begin{array}{c}\text { Processo de } \\
\text { Beneficiamento } \\
\text { da madeira }\end{array}$ & $\begin{array}{l}\text { Processo de } \\
\text { Construção }\end{array}$ \\
\hline Comunidade & 7,5 & 4,0 & 8,2 \\
\hline Relações com as organizações locais & 10,0 & 4,4 & \\
\hline Financiamento da ação social & 8,1 & 2,6 & \\
\hline Envolvimento com a ação social & 7,3 & 5,1 & 6,5 \\
\hline $\begin{array}{l}\text { Gerenciamento do impacto da empresa na } \\
\text { comunidade de entorno }\end{array}$ & 5,3 & 3,8 & 10,0 \\
\hline Relações com a comunidade do entorno & & & 10,0 \\
\hline Trabalho voluntário & & & 6,9 \\
\hline Participação comunitária & & & 10,0 \\
\hline \multirow[t]{2}{*}{ Benefícios para o negócio } & & & 9,1 \\
\hline & $\begin{array}{c}\text { Processo de } \\
\text { Produção } \\
\text { Florestal } \\
\end{array}$ & $\begin{array}{c}\text { Processo de } \\
\text { Beneficiamento } \\
\text { da madeira } \\
\end{array}$ & $\begin{array}{l}\text { Processo de } \\
\text { Construção }\end{array}$ \\
\hline Governo e sociedade & 4,9 & 2,9 & 5,6 \\
\hline Contribuições para campanhas políticas & 2,2 & 2,8 & \\
\hline Construção da cidadania pelas empresas & 4,7 & 2,2 & \\
\hline Práticas anti-corrupção e anti-propina & 4,7 & 2,8 & \\
\hline Liderança e influência social & 7,4 & 2,1 & \\
\hline $\begin{array}{l}\text { Participação em projetos sociais } \\
\text { governamentais }\end{array}$ & 5,3 & 4,2 & \\
\hline Participação e influência social & & & 10,0 \\
\hline $\begin{array}{l}\text { Participação e acompanhamento das } \\
\text { administrações públicas }\end{array}$ & & & 0,9 \\
\hline $\begin{array}{l}\text { Melhoria dos espaços públicos e apoio às } \\
\text { iniciativas sociais governamentais }\end{array}$ & & & 6,9 \\
\hline
\end{tabular}

Fonte: Autor. 
No próximo item serão apresentados em forma de texto alguns pontos qualitativos e quantitativos relevantes de cada empresa, procurando colocar questões significativas que influenciarão a análise final. A apresentação desses dados será feita por empresa, e dividida por ator envolvido.

\subsubsection{Processo de produção florestal.}

A empresa que faz o processo de produção florestal é de grande porte (multinacional) e está diretamente ligada à fabricação de outro produto, para onde a madeira produzida é escoada. Assim não foi possível precisar dados quanto ao número de funcionários voltados exclusivamente para a produção florestal, porém no total a empresa possui 2733 funcionários.

\section{I - Valores, Transparência e Governança.}

A empresa possui um documento formal amplamente divulgado, internamente e externamente, que abrange pontos relevantes, como conduta esperada, posicionamento frente a questões socioambientais, políticas de promoção de equidade e não discriminação das raças e gêneros, dentre outras. Esses princípios são utilizados para elaboração das estratégias da empresa, sendo incorporados em seus produtos e ações. Além da adoção desses princípios a empresa promove a utilização dos mesmos em toda a sua cadeia produtiva, monitorando-a através de auditorias, mesmo processo que é realizado dentro da empresa, através da elaboração de balanços sociais e certificações auditoradas por órgãos externos.

Os principais pontos negativos foram a não inclusão de políticas de concorrência em seu documento de regulação e conduta e a não participação do seu público internos na elaboração do mesmo, ficando esse processo a cargo da diretoria e equipe especializada.

Quadro 29: Indicadores quantitativos de governança corporativa da empresa Brancalhão

\begin{tabular}{|l|c|c|c|}
\hline & 2005 & 2006 & 2007 \\
\hline Total de membros do conselho de administração (ou estrutura similar). & 10 & 10 & 10 \\
\hline $\begin{array}{l}\text { Percentual do conselho de administração (ou estrutura similar) formado por } \\
\text { conselheiros independentes, sem cargo executivo. }\end{array}$ & $50 \%$ & $50 \%$ & $50 \%$ \\
\hline $\begin{array}{l}\text { Percentual de mulheres no conselho de administração (ou estrutura similar). } \\
\text { Percentual de negros (pretos e pardos) no conselho de administração (ou } \\
\text { estrutura similar). }\end{array}$ & $0 \%$ & $0 \%$ & $14 \%$ \\
\hline
\end{tabular}

Fonte: Relatório sócioambiental de 2007 da empresa responsável pelo processo de produção florestal. 


\section{II - Público interno.}

A empresa além de atender todos os requisitos da legislação vigente, possui diversos programas extras de melhoria da qualidade de vida de seu público interno, oferecendo benefícios extras de saúde, alimentação, lazer e cultura. Possui programa de aperfeiçoamento contínuo dos funcionários além de possuir programas de bolsas de estudo para cursos fora da área profissional específica como cursos técnicos, pré-vestibulares e universitários. A empresa também possui canal de diálogo aberto com sindicatos, oferecendo dados econômicos da empresa para acordos dos salários dos empregados e participação desses nos lucros da empresa. A empresa possui certificações da ISO 9000, ISO 14001 e SA8000, sofrendo auditorias externas para verificação das políticas adotadas quanto à qualidade de vida dos funcionários e práticas ambientais, e exige a mesma prática de seus fornecedores.

Os pontos de menor avanço em relação a esse tema é a não adoção de projetos que estimulam a não discriminação racial e de gênero em sua empresa, apesar de fazer censos para levantamentos dessas questões.

Quadro 30: Indicadores quantitativos do perfil dos empregados (dados de 2006)

\begin{tabular}{|l|c|c|c|}
\hline \multicolumn{1}{|c|}{ Empregados } & $\begin{array}{c}\text { Percentual em } \\
\text { relação ao total de } \\
\text { empregados (82) }\end{array}$ & $\begin{array}{c}\text { Percentual em relação } \\
\text { ao total de cargos de } \\
\text { gerência (7) }\end{array}$ & $\begin{array}{c}\text { Percentual em } \\
\text { relação ao total de } \\
\text { cargos executivos (3) }\end{array}$ \\
\hline Mulheres & $38,2 \%$ & & $14,8 \%$ \\
\hline $\begin{array}{l}\text { Mulheres negras (pretas e } \\
\text { pardas) }\end{array}$ & & & $0 \%$ \\
\hline $\begin{array}{l}\text { Funcionários negros } \\
\text { (pretos e pardos) }\end{array}$ & $12,22 \%$ & $0 \%$ & \\
\hline Pessoas com deficiência & $3,93 \%$ & & \\
\hline Pessoas acima de 45 anos & $13 \%$ & & \\
\hline
\end{tabular}

Fonte: Entrevista realizada com gerente de produção da empresa.

\section{III - Fornecedores.}

A empresa estabelece relações com os fornecedores para além das práticas usuais de mercado, exigindo as mesmas posturas desses quanto à responsabilidade social e certificados ambientais, fazendo auditorias para verificar o cumprimento desses, relatando a quebra de contrato com um dos fornecedores por apresentar trabalho infantil em sua empresa. Também adota procedimentos de compartilhar os resultados de suas pesquisas com os fornecedores, visando a melhoria de toda a cadeia produtiva envolvida, estimulando a responsabilidade sócioambiental. 


\section{IV - Consumidores e clientes.}

Possui canais formais e aberto a críticas para atendimento dos consumidores e tem como política de comunicação a criação de valores positivos na sociedade como forma de contribuir com o desenvolvimento sustentável, além de desenvolver parcerias com fornecedores, distribuidores, assistência técnica e representantes de consumidores para melhoramento do atendimento ao consumidor, visando criar uma cultura de responsabilidade e transparência na comunicação, colocando a sustentabilidade e responsabilidade social como diretrizes de sua política de vendas.

\section{V - Comunidade.}

Possui um programa de voluntariado dentro da empresa para auxílio comunitário, onde mais de 1000 funcionários participam. Também possui verba fixa destinada a projetos sociais de auxilio a comunidade, que estão principalmente dentro da área de educação, fornecendo aulas gratuitas de línguas e educação ambiental para a comunidade. Também auxilia através da doação de produtos e doação de horas dos técnicos da empresa para serviço especializado na comunidade.

O ponto negativo foi a não participação da comunidade na elaboração dos projetos ou na identificação das áreas carentes para elaboração de novos projetos de auxilio à comunidade, além dos projetos não apresentaram planos estratégicos que visem sua autonomia dos recursos da empresa a longo prazo.

\section{VI - Governo e sociedade.}

A empresa possui algumas ações sociais em associação ao governo em relação ao tema de educação infantil, e promove ações esporádicas de incentivo à cidadania dos funcionários. As contribuições políticas ficam sobre responsabilidade da direção da empresa, não havendo participação dos funcionários quanto a esse tipo de decisão.

\subsubsection{Processo de beneficiamento da madeira.}

A empresa que fez o beneficiamento da madeira chama-se Brancalhão, é uma empresa de porte médio e possui duas serrarias dentro de sua sede em Itapeva. As serrarias possuem 76 funcionários, um gerente de produção e os três diretores gerais da empresa, que são os proprietários. 


\section{I - Valores, transparência e governança.}

A empresa possui um pequeno documento formal que aborda os valores da empresa, que no entanto coloca somente questões de qualidade do produto e bom atendimento do mercado, não tendo grande divulgação entre os funcionários e nenhuma divulgação externa. Esses princípios também não são monitorados freqüentemente e nem por terceiros, e os funcionários não participam de sua elaboração ou revisão.

Quadro 31: Indicadores quantitativos de governança corporativa da empresa Brancalhão

\begin{tabular}{|l|c|c|c|}
\hline & 2004 & 2005 & 2006 \\
\hline Número de membros do Conselho de Administração & 3 & 3 & 3 \\
\hline $\begin{array}{l}\text { Percentual do Conselho de Administração formado por } \\
\text { conselheiros independentes, sem cargos executivos. }\end{array}$ & 0 & 0 & 0 \\
\hline $\begin{array}{l}\text { Percentual de mulheres no Conselho de Administração } \\
\text { (ou em estrutura similar) }\end{array}$ & 2 & 2 & 2 \\
\hline $\begin{array}{l}\text { Percentual de negros (pretos e pardos) no Conselho de } \\
\text { Administração (ou em estrutura similar) }\end{array}$ & 0 & 0 & 0 \\
\hline
\end{tabular}

Fonte: Entrevista realizada com gerente de produção da empresa.

\section{II - Público interno.}

A empresa atende à legislação vigente quanto ao pagamento de benefícios e encargos dos funcionários, e não possui nenhum programa especial para treinamento e melhoria profissional, educação, etc. É assegurado o livre direito de filiação sindical, porém não existe mecanismos formais para participação dos funcionários nas resoluções de problemas dentro da empresa. Possui programa de treinamento para segurança no trabalho com equipe interna responsável pelo seu monitoramento.

Quadro 32: Indicadores quantitativos do perfil dos empregados (dados de 2006)

\begin{tabular}{|l|c|c|c|}
\hline \multicolumn{1}{|c|}{ Empregados } & $\begin{array}{c}\text { Número de } \\
\text { empregados(as) e } \\
\text { percentual em } \\
\text { relação ao total de } \\
\text { empregados da } \\
\text { serraria (82) }\end{array}$ & $\begin{array}{c}\text { Número de } \\
\text { empregados(as) e } \\
\text { percentual em cargos } \\
\text { de gerencial em } \\
\text { relação ao total de } \\
\text { cargos de gerência (7) }\end{array}$ & $\begin{array}{c}\text { Número de } \\
\text { empregados(as) e } \\
\text { percentual em cargos } \\
\text { de diretoria em } \\
\text { relação ao total de } \\
\text { cargos executivos (3) }\end{array}$ \\
\hline Mulheres & $11-13,75 \%$ & $0-0 \%$ & $1-33,33 \%$ \\
\hline $\begin{array}{l}\text { Mulheres negras (pretas } \\
\text { e pardas) }\end{array}$ & $5-6,25 \%$ & $0-0 \%$ & $0-0 \%$ \\
\hline $\begin{array}{l}\text { Homens negros (pretos } \\
\text { e pardos) }\end{array}$ & $34-42,5 \%$ & $2-28,57 \%$ & $0-0 \%$ \\
\hline Pessoas com deficiência & $1-1,25 \%$ & $0-0 \%$ & $0-0 \%$ \\
\hline $\begin{array}{l}\text { Pessoas acima de } 45 \\
\text { anos }\end{array}$ & $0-0 \%$ & $0-0 \%$ & $1-33,33 \%$ \\
\hline
\end{tabular}

Fonte: Entrevista realizada com gerente de produção da empresa. 


\section{III - Fornecedores.}

A empresa mantém os critérios de mercado para seleção de fornecedores como qualidade, preço e prazo e não procura fiscalizar sua cadeia produtiva quanto a trabalho infantil ou outras práticas ilegais.

\section{IV - Consumidores e clientes.}

A empresa adota medidas preventivas ou remediativas quanto a danos potenciais de seus produtos e possui somente canais informais para recebimento de críticas e sugestões.

\section{V - Comunidade.}

A empresa procurou localizar-se em área que não afeta a comunidade e apoiar várias entidades locais com doações, financiamento e implementação de projetos de forma esporádica, além de possuir uma fundação para auxílio de jovens carentes do município de Itapeva. A empresa também cede horas dos empregados para trabalhos voluntários.

\section{VI - Governo e sociedade.}

A empresa não possui nenhum projeto de ação social vinculado ao governo, não promove projetos de incentivo à cidadania para seus funcionários, que por sua vez não participam das decisões de doações para campanhas políticas.

\subsubsection{Processo de construção do sistema estrutural de cobertura.}

Para entendimento da estrutura de funcionamento do processo de construção do sistema estrutural de cobertura deve-se lembrar que este é composto pela pré-fabricação dos componentes em vigas laminadas pregadas na marcenaria coletiva, e pela montagem do sistema em canteiro, executados em regime de mutirão. Portanto, podemos dividir da seguinte maneira os serviços nessa operação:

1. Pré-fabricação dos componentes em Eucalipto (chapuz, espaçadores): feita integralmente pelos mutirantes especializados da marcenaria coletiva.

\section{Pré-fabricação dos componentes laminados pregados em madeira de Pinus:}

- O posicionamento das lâminas de Pinus na mesa de gabarito e pregação foram feitos por cada morador (sem trocas de horas com os mutirantes especializados em marcenaria) em 
sistema de mutirão, organizados em grupos ou não. Cada pessoa levou em média 1,2 dias para pregar todos os componentes de sua casa.

- Etapas de destopo, refilo e desengrosso foram feitas pelos mutirantes especializados em marcenaria, onde cada hora trabalhada na marcenaria equivalia a uma hora de trabalho no canteiro de obras. A pré-fabricação de todos os componentes para as 36 habitações foi feita em 2,5 meses ou 54 dias de trabalho, portanto cada habitação levou em média 1,5 dia para ter suas peças usinadas.

3. Montagem do sistema pré-fabricado no canteiro de obras: feita por cada morador (sem trocas de horas com os mutirantes especializados em marcenaria) em sistema de mutirão, organizados em grupos ou não.

\section{Aplicação do sistema preservativo sobre o sistema estrutural montado em} canteiro: feita por cada morador (sem trocas de horas com os mutirantes especializados em marcenaria) em sistema de mutirão, organizados em grupos ou não.

5. Manutenção do sistema estrutural: consiste na reaplicação do preservativo sobre o sistema estrutural montado em canteiro e deverá ser feita por cada morador (sem trocas de horas com os mutirantes especializados em marcenaria).

6. Desconstrução do sistema estrutural: após o fim de sua vida útil deverá ser feita por cada morador (sem trocas de horas com os mutirantes especializados em marcenaria).

Não será possível avaliar as operações de manutenção e desconstrução, pois além de não ter sido feita a primeira manutenção ou desconstrução, essas operações deverão ser feitas individualmente pelos moradores. Portanto a análise será feita sobre o processo de construção, mais especificamente nas etapas de pré-fabricação e sua troca de serviço com os mutirantes da montagem do sistema.

\section{I - Valores, transparência e governança.}

Foram elaborados documentos formais e regimentos internos (marcenaria e mutirão) esclarecendo os princípios e valores (solidariedade, compromisso, coragem, responsabilidade, organização, paciência, compreensão, determinação, respeito e disciplina) com temas que deveriam ser incentivados, como comportamentos e relações de trabalho, porém não abordam temas como punições para corrupção e propinas. O documento tem ampla divulgação interna, porém não tem divulgação para outros atores, e cabe somente aos integrantes monitorá-la. 
A estrutura montada para a gestão e tomada de decisões é feita através de reuniões gerais e assembléias, onde todos os integrantes da cooperativa, mutirantes e da assessoria técnica participam.

Quadro 33: Indicadores quantitativos da governança coporativa da marcenaria coletiva

\begin{tabular}{|l|c|}
\hline & 2006 \\
\hline Número de membros do Conselho de Administração & 8 \\
\hline $\begin{array}{l}\text { Percentual do Conselho de Administração formado por conselheiros } \\
\text { independentes, sem cargos executivos. }\end{array}$ & $100 \%$ \\
\hline Percentual de mulheres no Conselho de Administração (ou em estrutura similar) & $87,5 \%$ \\
\hline $\begin{array}{l}\text { Percentual de negros (pretos e pardos) no Conselho de Administração (ou em } \\
\text { estrutura similar) }\end{array}$ & $62,5 \%$ \\
\hline
\end{tabular}

Fonte: Entrevista realizada com os membros da marcenaria em 2006.

\section{II - Público interno.}

Os critérios para participação na marcenaria coletiva e no mutirão beneficiaram as pessoas da região do projeto, historicamente desfavorecidas, com baixa renda e escolaridade. A marcenaria e o mutirão procuram a maior diversidade possível de gênero e raças, e no caso específico da marcenaria os trabalhadores são em quase sua totalidade mulheres, muitas delas negras ou pardas. Durante todo o processo de mutirão houve uma grande preocupação com a formação dos seus mutirantes (que anteriormente nunca haviam trabalhado com marcenaria, gestão de cooperativas ou construção civil) oferecendo-se oportunidades de capacitação a uma população de baixa renda e não capacitada para esse tipo de empreendimento, através da parceria com universidades e especialistas, que dividiam todas as informações técnicas e de gerenciamento com as famílias através de reuniões e assembléias. Com relação à segurança no trabalho foram criadas comissões para fiscalização dos cumprimentos dos acordos do regimento como uso de equipamentos de segurança.

Nesse processo os mutirantes não tiveram remuneração ou benefícios, e não estavam cobertos com seguro para acidentes, taxas de previdência e não eram filiados a qualquer sindicato. Também não foram feitas adaptações para deficientes nos locais de trabalho ou nos projetos propostos. 
Quadro 34: Indicadores quantitativos do perfil dos cooperados da marcenaria coletiva madeirarte (dados de 2006).

\begin{tabular}{|l|c|c|c|}
\hline Empregados & $\begin{array}{c}\text { Número de } \\
\text { empregados(as) e } \\
\text { percentual em } \\
\text { relação ao total de } \\
\text { empregados da } \\
\text { serraria (8) }\end{array}$ & $\begin{array}{c}\text { Número de } \\
\text { empregados(as) e } \\
\text { percentual em cargos } \\
\text { gerenciais em relação } \\
\text { ao total de cargos de } \\
\text { gerência (8) }\end{array}$ & $\begin{array}{c}\text { Número de } \\
\text { empregados(as) e } \\
\text { percentual em cargos } \\
\text { de diretoria em } \\
\text { relação ao total de } \\
\text { cargos executivos (8) }\end{array}$ \\
\hline Mulheres & $7-87,5 \%$ & $7-87,5 \%$ & $7-87,5 \%$ \\
\hline $\begin{array}{l}\text { Mulheres negras } \\
\text { (pretas e pardas) }\end{array}$ & $5-62,5 \%$ & $5-62,5 \%$ & $5-62,5 \%$ \\
\hline $\begin{array}{l}\text { Homens negros } \\
\text { (pretos e pardos) }\end{array}$ & $1-12,5 \%$ & $1-12,5 \%$ & $1-12,5 \%$ \\
\hline $\begin{array}{l}\text { Pessoas com } \\
\text { deficiência }\end{array}$ & $0-0 \%$ & $0-0 \%$ & $0-0 \%$ \\
\hline $\begin{array}{l}\text { Pessoas acima de } 45 \\
\text { anos }\end{array}$ & $4-50 \%$ & $4-50 \%$ & $4-50 \%$ \\
\hline
\end{tabular}

Fonte: Entrevista realizada com os membros da marcenaria em 2006.

\section{III - Fornecedores.}

O empreendimento teve uma postura usual de mercado quanto à escolha e auxílio dos fornecedores, dando prioridade para produto, prazo e qualidade.

\section{IV - Consumidores e clientes.}

No caso desse empreendimento os consumidores e clientes eram os próprios mutirantes, assim, através de processos participativos em canais formais (reuniões e assembléias), as famílias participavam ativamente das discussões e das decisões a serem tomadas, resultando em um alto grau de satisfação. Com o auxílio da assistência técnica da universidade ainda pôde-se detectar os possíveis impactos das atividades que seriam feitas, tomando medidas preventivas ou remediativas, quando necessário.

\section{V - Comunidade.}

O projeto do mutirão e da marcenaria coletiva foi criado a partir das diretrizes elaboradas pela própria comunidade, através do processo participativo, procurando beneficiar a si mesmos e aos atores locais. Assim, o projeto contribuiu com a geração de trabalho e renda para as famílias que participam desse processo, melhorando a qualidade de vida da comunidade local. Atualmente a marcenaria procura priorizar a demanda da população de baixa renda local, oferecendo produtos acessíveis, além de oferecer aos jovens da comunidade a oportunidade de aprender um novo ofício e futuramente participar da cooperativa. 


\section{VI - Governo e sociedade.}

O projeto de construção das habitações partiu de uma ação financiada por órgãos governamentais para melhoria das condições da comunidade, sendo então alvo e não proponente dessas iniciativas, servindo como um exemplo de iniciativa para melhoria de qualidade de vida da população de baixa renda de assentamentos rurais. Assim os projetos do mutirão autogerido e da marcenaria coletiva participaram de várias exposições e concorreram como melhores práticas sociais, com grande divulgação no meio acadêmico.

\subsection{Apresentação dos dados da dimensão econômica.}

O levantamento da dimensão econômica, assim como da dimensão social, seguiu as classes de variáveis já descritas na seleção de categorias do método de responsabilidade social do Instituto Ethos, que aborda o nível de ação empresarial.

\subsubsection{Processo de produção florestal}

Nesse processo será analisada a empresa A, já descrita no item sobre a dimensão social.

\section{I) Produtividade}

A produtividade da empresa para o ciclo de 25 anos de um ha de Pinus pode ser verificada a partir do quadro 35.

Quadro 35: Produtividade da empresa para o ciclo de 25 anos de um ha de plantio de Pinus.

\begin{tabular}{|c|c|c|c|}
\hline Matérias primas adquiridas & $\begin{array}{l}\text { para } 1 \text { ciclo de } \\
25 \text { anos }\end{array}$ & Custo R\$ & Origem \\
\hline herbicida a base de glifosati & $18 \mathrm{~kg}$ & \multirow{5}{*}{$\begin{array}{l}\text { Total com } \\
\text { mão-de- } \\
\text { obra } \\
\text { R\$ 4429,00 }\end{array}$} & \multirow{5}{*}{ Empresa terceirizada. } \\
\hline formicida a base de sufloramida & $25 \mathrm{~kg}$ & & \\
\hline cupinicida canfidor & $25 \mathrm{~g}$ & & \\
\hline adubo (fosfato) & $300 \mathrm{~kg}$ & & \\
\hline mudas Pinus Caribea var. hondurensis & 1667 unidades & & \\
\hline $\begin{array}{l}\text { Produtos produzidos } \\
\text { (incluindo resíduos) }\end{array}$ & $\begin{array}{l}\text { para } 1 \text { ciclo de } \\
25 \text { anos }\end{array}$ & Custo R\$ & Destino \\
\hline Toretes (diam. Até 14) & $35 \mathrm{~m} \mathrm{st}$. & $\mathrm{R} \$ 40,00$ & Energia \\
\hline Toras (diam. Até 20) & $40 \mathrm{~m} \mathrm{st}$ & $\mathrm{R} \$ 50,00$ & Energia e serrarias \\
\hline Toras (diam. Até 38) & $402 \mathrm{~m} \mathrm{st}$. & $\mathrm{R} \$ 50,00$ & Serrarias e fabricação de \\
\hline Acículas, galhos e raízes & --- & --- & Decomposição e adubagem. \\
\hline
\end{tabular}

Fonte: Entrevista realizada com gerente de produção da empresa. 


\section{II) Investimentos}

\section{- Investimento em pesquisa e desenvolvimento mais sustentável}

A empresa possui certificados de qualidade ambiental, como o ISO 14001 e o FSC (certificado reconhecido internacionalmente na área de plantios e manejo florestal), procurando garantir a qualidade ambiental de seus produtos. Além disso possui um setor especializado em pesquisas que estuda melhorias dentro das seguintes áreas:

Solo: estudos de sistema de cultivo mínimo, controle e prevenção de processos erosivos, monitoramento e correção nutricional.

Água: estudos para conservação da mata ciliar, análises físico-químicas dos corpos d'água (coleta de 4 amostras por ano tendo 54 parâmetros), padrões rígidos para cruzamento de cursos d'água.

Flora: Demarcação e proteção das áreas de preservação permanente, projetos de recuperação da biodiversidade e preservação permanente, convênio com IEF para trocas de mudas (6 de Pinus por 1 nativa), pesquisa de metodologia para restauração de áreas de reserva legal ocupadas atualmente por Pinus, controle mecânico da infestação do Pinus e áreas adjacentes.

Fauna: Monitoramento populacional da fauna de aves e mamíferos presentes nos parques florestais há 12 anos.

Fogo: Proteção contra aceiros, conscientização de vizinhos, detecção através de torres e vigilância motorizada, além do combate pela brigada de incêndio, registro de estatísticas.

\section{- Investimento na procura de uma maior produtividade}

Criação de um pomar de sementes clonal próprio e estudo de espécies mais produtivas. Também possui estudos quanto à adubação e controle de pragas.

\section{- Investimento na procura de um aumento na capacidade produtiva}

A empresa que antes trabalhava com áreas de plantio florestal terceirizadas já investiu na compra de áreas próprias para esse fim.

\section{- Investimento na educação e treinamento de funcionários}

Todos os funcionários passam regularmente por treinamento quanto à segurança no trabalho, e treinamentos anuais de educação ambiental, além de serem oferecidos treinamentos de reciclagem dos funcionários. A média de treinamentos é de 60 horas/ano/funcionário com gasto de 1\% da renda líquida da empresa. 


\section{- Investimento em programas de auxílio à comunidade}

Além de doações regulares de produtos para a comunidade, a empresa participa de projetos de educação ambiental para a comunidade local, capacitando multiplicadores nas escolas públicas e ainda oferece cursos de línguas e música para crianças carentes. O investimento da empresa no ano de 2006 foi de $0,257 \%$ da renda líquida da empresa.

\section{III) Distribuição de riquezas}

A empresa divide seus gastos de acordo com o quadro 36 abaixo:

Quadro 36: Divisão dos gastos mensais da empresa A.

\begin{tabular}{|l|l|}
\hline \multicolumn{2}{|c|}{ Divisão dos gastos mensais da empresa } \\
\hline Custo operacional & $\mathrm{R} \$ 123.182 .000,00$ \\
\hline Pagamento de funcionários & $\mathrm{R} \$ 104.533 .000,00$ \\
\hline Benefícios dos funcionários & $\mathrm{R} \$ 41.039 .000,00$ \\
\hline Impostos & $\mathrm{R} \$ 38.950 .000,00$ \\
\hline Contribuição para a comunidade & $\mathrm{R} \$ 788.000,00$ \\
\hline Projeto meio ambiente & $\mathrm{R} \$ 3.531 .000,00$ \\
\hline Lucro operacional & $\mathrm{R} \$ 40.650 .000,00$ \\
\hline Total ou Receita Liquida & $\mathrm{R} \$ 352.673 .000,00$ \\
\hline
\end{tabular}

Fonte: Relatório Socioeconômico de 2006/2007 da empresa A.

\section{Distribuição de riquezas}

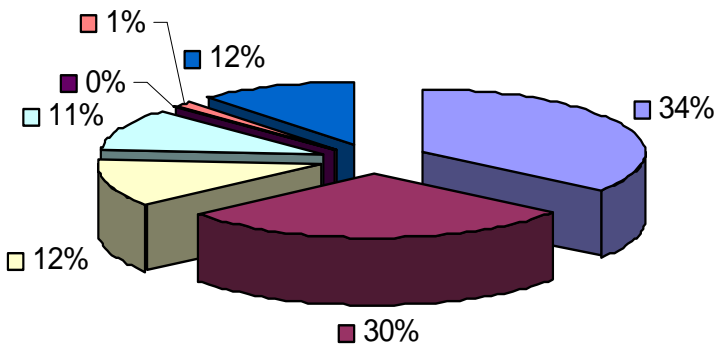

$\square$ Custo operacional

$\square$ Pagamento de funcionários $\square$ Benefícios dos funcionários

Impostos

$\square$ Contr. Comunidade

$\square$ Proj. meioambiente

clucro operacional

Figura 36: Distribuição de riquezas da empresa A, responsável pelo processo de produção florestal. Fonte: Relatório Socioeconômico de 2006/2007 da empresa A. 


\subsubsection{Processo de beneficiamento da madeira}

Nesse processo será analisada a empresa Brancalhão, já descrita no item sobre a dimensão social.

\section{I) Produtividade}

A produtividade da serraria pode ser verificada a partir do quadro 37.

Quadro 37: Produtividade da serraria Brancalhão.

\begin{tabular}{|c|c|c|c|}
\hline Matérias primas adquiridas & $\begin{array}{c}\text { Quantidade } \\
\text { mensal }\end{array}$ & Custo R\$ & Origem \\
\hline $\begin{array}{l}\text { Toras de Pinus Elliottii e Taeda } \\
\text { (misturadas e sem determinação de } \\
\text { quantidade de cada tipo), } \\
\text { Comprimentos e diâmetros variados } \\
\text { (menor diâmetro a partir de } 18 \mathrm{~cm} \text { ). }\end{array}$ & $8000 \mathrm{~m} \mathrm{st}$ & $\begin{array}{l}1200 / \mathrm{m}^{3} \text { de } \\
\text { madeira } \\
\text { serrada de } \\
1^{\mathrm{a}} \text {. }\end{array}$ & $\begin{array}{l}\text { O fornecedor é a Eucatex. Sua } \\
\text { floresta está no município de } \\
\text { Itapeva na fazenda Estreito a } 30 \\
\text { km da serraria. }\end{array}$ \\
\hline Quelato de Cobre & 150 litros/ mês & $\begin{array}{c}892,5 \text { ou } \\
5,95 / \text { litro }\end{array}$ & Montana. \\
\hline $\begin{array}{l}\text { Produtos produzidos (incluindo } \\
\text { resíduos) }\end{array}$ & $\begin{array}{c}\text { Quantidade } \\
\text { mensal }\end{array}$ & Custo R\$ & destino \\
\hline \multicolumn{4}{|l|}{ Produção em 2007} \\
\hline Madeiras serradas de $1^{\text {a }}$ seca estufa & \multirow{3}{*}{$1704 \mathrm{~m}^{3}$} & 360 & \multirow{3}{*}{ Construção civil e embalagens } \\
\hline Madeiras serradas de $1^{\text {a }}$ seca varal & & 330 & \\
\hline Madeiras serradas de $1^{\mathrm{a}}$ verdes & & 320 & \\
\hline Madeiras serradas de $2^{a}$ seca estufa & $200 \mathrm{~m}^{3}$ & 260 & Indústria moveleira \\
\hline Pó-de-serra & $700 \mathrm{~m} \mathrm{st}$ & $12 / \mathrm{m} \mathrm{st}$ & $\begin{array}{l}\text { Granjas e confinamento de } \\
\text { bovinos }\end{array}$ \\
\hline Cavaco & $2600 \mathrm{~m} \mathrm{st}$ & -- & Queima em fornos \\
\hline $\begin{array}{l}\text { Mistura de casca e refilos em } \\
\text { decomposição }\end{array}$ & -- & -- & Fabricação de adubo \\
\hline $\begin{array}{l}\text { Produtos produzidos (incluindo } \\
\text { resíduos) }\end{array}$ & $\begin{array}{c}\text { Quantidade } \\
\text { mensal }\end{array}$ & Custo R\$ & destino \\
\hline \multicolumn{4}{|l|}{ Produção em 2004} \\
\hline Madeiras serradas de $1^{a}$ seca estufa & $1488 \mathrm{~m}^{3}$ & -- & Construção civil e embalagens \\
\hline Madeiras serradas de $2^{a}$ seca estufa & $427 \mathrm{~m}^{3}$ & -- & Industria moveleira \\
\hline Madeiras serradas de $3^{\text {a }}$ seca no varal & $214 \mathrm{~m}^{3}$ & 197,43 & variado \\
\hline Pó-de-serra & \multirow{2}{*}{$\begin{array}{c}\text { Será } \\
\text { considerada a } \\
\text { média da } \\
\text { produção atual }\end{array}$} & -- & $\begin{array}{l}\text { Granjas e confinamento de } \\
\text { bovinos }\end{array}$ \\
\hline Cavaco & & -- & Queima em fornos \\
\hline
\end{tabular}

Fonte: Entrevista realizada com gerente de produção da empresa. 


\section{II) Investimentos}

- Investimento em pesquisa e desenvolvimento mais sustentável

Está sendo feita uma cisterna para captação de águas de chuva para diminuir o uso do poço artesiano. Também foi implementado um equipamento para fabricar o cavaco com os resíduos do desdobro (refilos, costaneiras e destopos) que passam a servir como fonte energética para outros processos.

- Investimento na procura de uma maior produtividade

Foram feitas mudanças nos tipos de serra utilizadas para obter uma maior produtividade além da adoção de esteiras rolantes para o transporte de alguns resíduos.

- Investimento na procura de um aumento na capacidade produtiva

Não houve investimento na capacidade produtiva, pois o mercado madeireiro não está crescendo. Isso se deve ao câmbio do dólar que não está favorecendo a exportação, deixando o mercado brasileiro com sobra de madeira serrada e conseqüentemente resultando na queda do preço.

\section{- Investimento na educação e treinamento de funcionários}

A empresa procura contratar pessoas já capacitadas, e a procura de melhoria ou treinamento se dá informalmente através da observação dos funcionários durante o trabalho e orientações. Existe um treinamento feito com especialistas em engenharia do trabalho para orientações quanto à segurança no trabalho e prevenção de acidentes.

\section{- Investimento em programas de auxílio à comunidade}

Os investimentos se destinam à Fundação Brancalhão (fundação de auxílio alimentar e educacional aos jovens carentes da comunidade) e à assistência direta à população.

\section{III) Distribuição de riquezas}

A distribuição de riquezas da empresa está apresentada no quadro 38 e no gráfico da figura 37: 
Quadro 38: Distribuição de riquezas da empresa Brancalhão.

\begin{tabular}{|l|c|}
\hline \multicolumn{2}{|c|}{ Distribuição de riquezas da empresa Brancalhão } \\
\hline Matéria Prima & $\mathrm{R} \$ 440.000,00$ \\
\hline Lucro operacional (2 proprietários) & $\mathrm{R} \$ 132.214$ \\
\hline Empregados (82) & $\mathrm{R} \$ 64.000$ \\
\hline Pagamento de terceiros & $\mathrm{R} \$ 30.000,00$ \\
\hline Manutenção & $\mathrm{R} \$ 20.000,00$ \\
\hline Impostos & $\mathrm{R} \$ 16.000,00$ \\
\hline Renda bruta total & $\mathrm{R} \$ 682.214,00$ \\
\hline
\end{tabular}

Fonte: Entrevista realizada com gerente de produção da empresa.

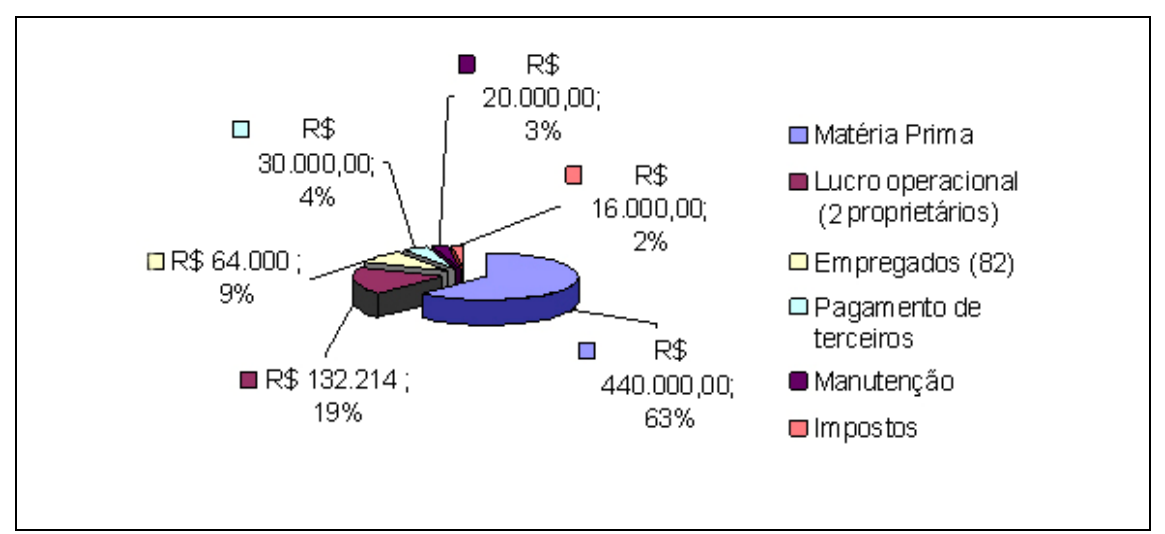

Figura 37: Gráfico da distribuição do orçamento da empresa Brancalhão. Fonte: Autor.

\subsubsection{Processo de construção do sistema estrutural de cobertura}

No processo de construção serão analisadas todas as operações conjuntamente.

\section{A) Operação de pré-fabricação}

\section{I) Produtividade}

Quadro 39: Produtividade da marcenaria coletiva.

\begin{tabular}{|l|c|c|l|}
\hline $\begin{array}{c}\text { Entradas de matérias } \\
\text { primas }\end{array}$ & $\begin{array}{c}\text { Quantidade por } \\
\text { casa }\end{array}$ & Custo em R\$ & \multicolumn{1}{|c|}{ Origem } \\
\hline $\begin{array}{l}\text { Madeira de Pinus de } 3^{\mathrm{a}} \\
\text { qualidade }\end{array}$ & $3,74 \mathrm{~m}^{3}$ & $\mathrm{R} \$ 197,43 / \mathrm{m}^{3}$ & Serraria Brancalhão \\
\hline Madeira de Eucalipto & $0,14 \mathrm{~m}^{3}$ & $\mathrm{R} \$ 365,00 / \mathrm{m}^{3}$ & Serraria Modular \\
\hline Pregos & $\begin{array}{c}21,46 \mathrm{~kg}(17 \mathrm{x} 27) \\
0,52 \mathrm{~kg}(15 \mathrm{x} 15)\end{array}$ & $\mathrm{R} \$ 5,00 / \mathrm{kg}$ & Ind. Klabim \\
\hline
\end{tabular}

Continua 


\begin{tabular}{|l|c|l|l|}
\hline $\begin{array}{c}\text { Saídas de produtos (e } \\
\text { resíduos) }\end{array}$ & $\begin{array}{c}\text { Quantidade } \\
\text { mensal }\end{array}$ & Custo em R\$ & \multicolumn{1}{|c|}{ Destino } \\
\hline $\begin{array}{l}\text { Sistema estrutural em } \\
\text { VLP pré-fabricado. }\end{array}$ & $39,91 \mathrm{~m}^{3}$ & & Sistema estrutural de cobertura \\
\hline $\begin{array}{l}\text { Madeira de Pinus de 3 } \\
\text { qualidade rejeitada }\end{array}$ & $0,54 \mathrm{~m}^{3}$ & $\begin{array}{l}\text { Passarinheira do sistema de cobertura } \\
\text { e outros sub-usos. }\end{array}$ \\
\hline $\begin{array}{l}\text { Pó-de-serra, cepilho, } \\
\text { refilo e destopos. }\end{array}$ & $0,43 \mathrm{~m}^{3}$ & $\begin{array}{l}\text { Podem ter fins energéticos ou como } \\
\text { forragens para granjas e } \\
\text { posteriormente adubo. }\end{array}$ \\
\hline
\end{tabular}

Fonte: Grupo de pesquisa Habis.

\section{II) Investimentos}

\section{- Investimento em pesquisa e desenvolvimento mais sustentável}

Pode-se considerar que todos os investimentos descritos abaixo foram feitos com o objetivo de um maior desenvolvimento sustentável, pois seguem diretrizes de um projeto de habitações mais sustentáveis.

\section{- Investimento na procura de uma maior produtividade}

Todo o investimento alocado na criação da marcenaria coletiva visava uma maior produtividade visto que essa atividade não era feita nesse assentamento anteriormente.

\section{- Investimento na procura de um aumento na capacidade produtiva}

Todo o investimento alocado na criação da marcenaria coletiva visava uma maior capacidade produtiva visto que esse não era um empreendimento existente nesse assentamento.

Ver formação da marcenaria coletiva no capítulo 2.

\section{- Investimento na educação e treinamento de funcionários}

O investimento em treinamento foi feito através do recurso alocado para um marceneiro instrutor e para pesquisadores, que também faziam capacitações de diversos tópicos de marcenaria e autogestão.

\section{- Investimento em programas de auxílio à comunidade}

Pode-se considerar que todos os investimentos descritos acima foram feitos com o objetivo de auxiliar a comunidade, pois são destinados somente à população local, sendo os benefícios revertidos para a mesma. 


\section{III) Distribuição de riquezas}

Para essa operação, os custos de manutenção e pagamento da assessoria foram feitos com recursos de editais do governo federal e estadual, destinando-se mensalmente $\mathrm{R} \$ 1.200,00$ para deslocamento e estadia, $R \$ 850,00$ para pagamento de um técnico da universidade e $R \$ 470,00$ para pagamento de um marceneiro instrutor, somando $R \$ 2.520,00$ por mês ou $R \$ 6.300,00$ em 2,5 meses, período de produção dos componentes.

Considerando ainda que nesse período o único gasto com manutenção foi o pagamento da energia elétrica, e que a média de gastos da marcenaria atualmente é de $R \$ 120,00$, tem-se que foram gastos $\mathrm{R} \$ 300,00$ em manutenção, pagos pelos recursos dos editais.

Pode-se observar a distribuição de custos globais na figura 38 e a distribuição mais detalhada dos materiais utilizados no sistema estrutural em VLP, no quadro 40 e na figura 39.

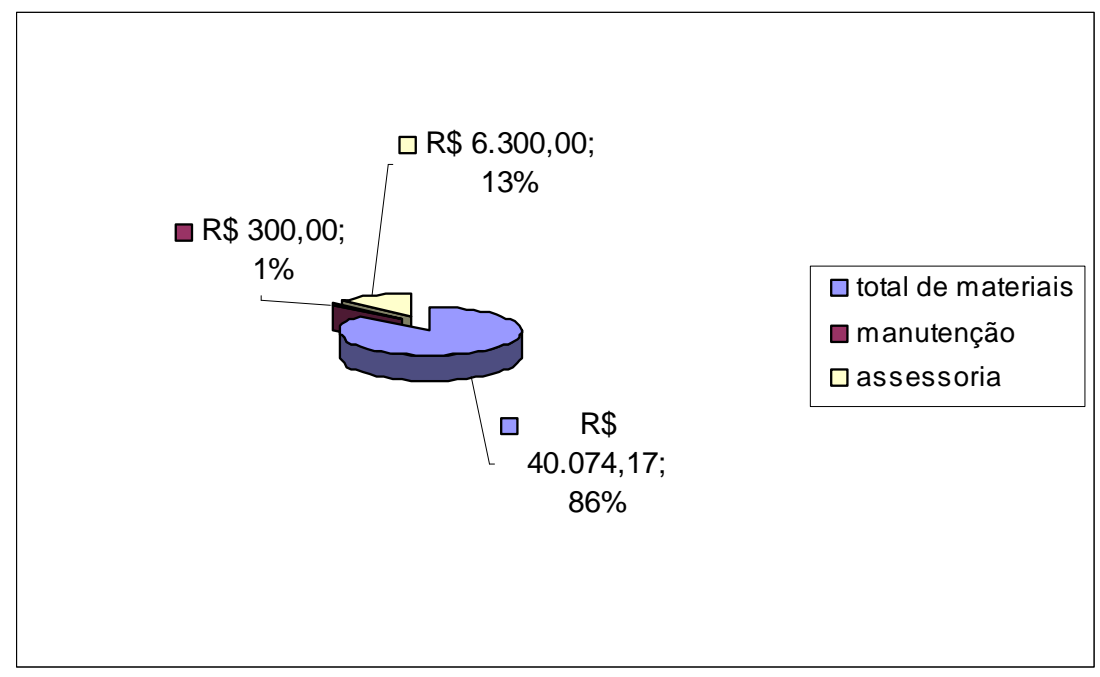

Figura 38: Custos da globais da implantação do sistema estrutural Fonte: Autor.

Quadro 40: Composição de custos dos materiais do sistema estrutural em VLP.

\begin{tabular}{|l|c|c|c|}
\hline \multicolumn{1}{|c|}{ Material } & Quantidade & Preço unitário & Total parcial \\
\hline Madeira de Pinus & 3,612001 & $\mathrm{R} \$ 197,43$ & $\mathrm{R} \$ 713,12$ \\
\hline Madeira de Eucalipto & 0,14234 & $\mathrm{R} \$ 365,00$ & $\mathrm{R} \$ 51,95$ \\
\hline Pregos & 21,98 & $\mathrm{R} \$ 5,00$ & $\mathrm{R} \$ 109,90$ \\
\hline Cabo de aço & 36 & $\mathrm{R} \$ 0,41$ & $\mathrm{R} \$ 14,76$ \\
\hline Chapa de aço & 12 & $\mathrm{R} \$ 1,00$ & $\mathrm{R} \$ 12,00$ \\
\hline Clips de aço & 6 & $\mathrm{R} \$ 0,32$ & $\mathrm{R} \$ 1,92$ \\
\hline Tratamento pentox & 1 & $\mathrm{R} \$ 102,67$ & $\mathrm{R} \$ 102,67$ \\
\hline Tratamento pirolenhoso & 76 & $\mathrm{R} \$ 1,13$ & $\mathrm{R} \$ 85,50$ \\
\hline Parafusos & 35 & $\mathrm{R} \$ 0,61$ & $\mathrm{R} \$ 21,35$ \\
\hline & & Total & $\mathbf{R} \mathbf{1 . 1 1 3 , 1 7}$ \\
\hline
\end{tabular}

Fonte: Grupo de pesquisa Habis. 


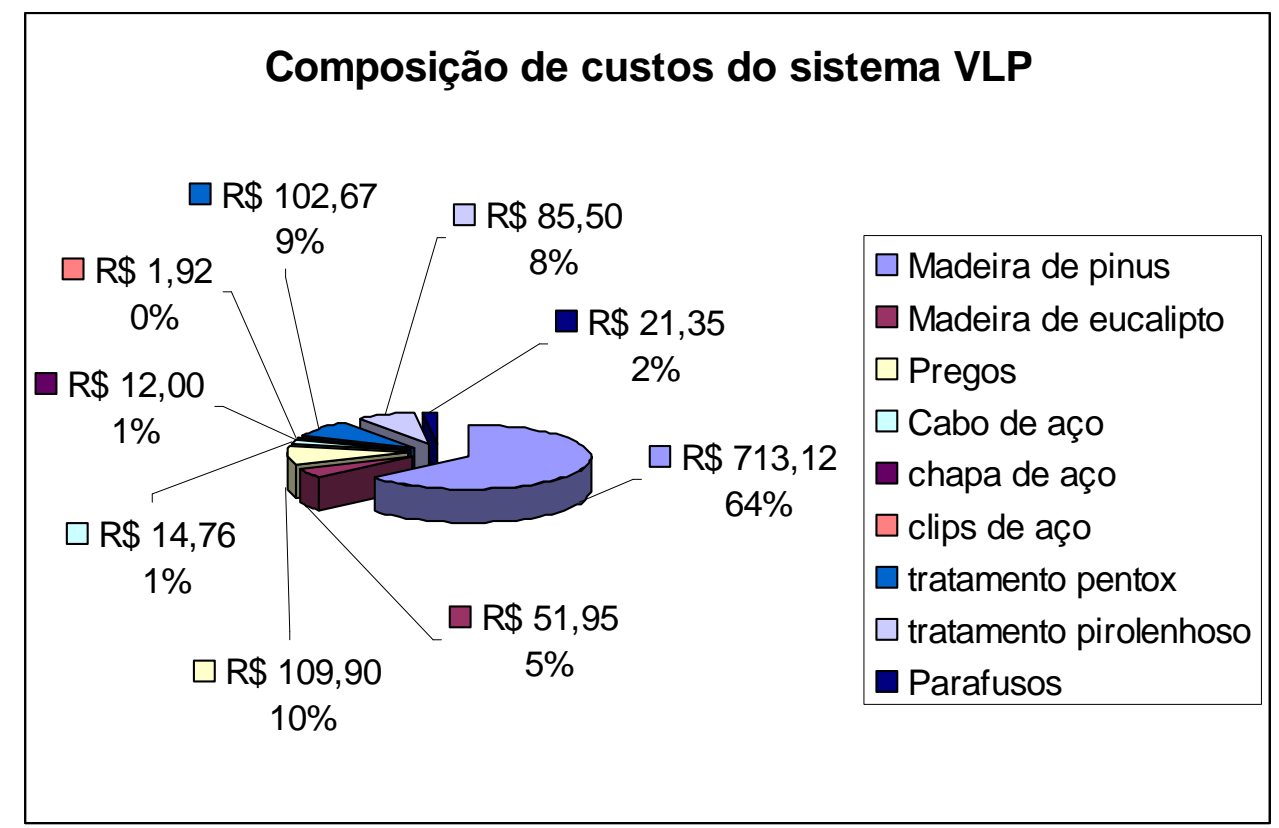

Figura 39: Gráfico da composição de custos do sistema estrutural em vigas laminadas pregadas. Fonte: Autor.

Também pode-se avaliar os custos globais do sistema ao longo da cadeia, apresentados no quadro 41 e no gráfico da figura 40.

Quadro 41: Custo do sistema estrutural em VLP durante o ciclo de vida.

\begin{tabular}{|l|c|}
\hline \multicolumn{2}{|c|}{ Custos do sistema durante o ciclo de vida } \\
\hline Materiais construtivos & $\mathrm{R} \$ 1.113,17$ \\
\hline Tratamento preservativo & $\mathrm{R} \$ 102,67$ \\
\hline Manutenção & $\mathrm{R} \$ 821,36$ \\
\hline Desconstrução & $\mathrm{R} \$ 0,00$ \\
\hline
\end{tabular}

Fonte: Autor.

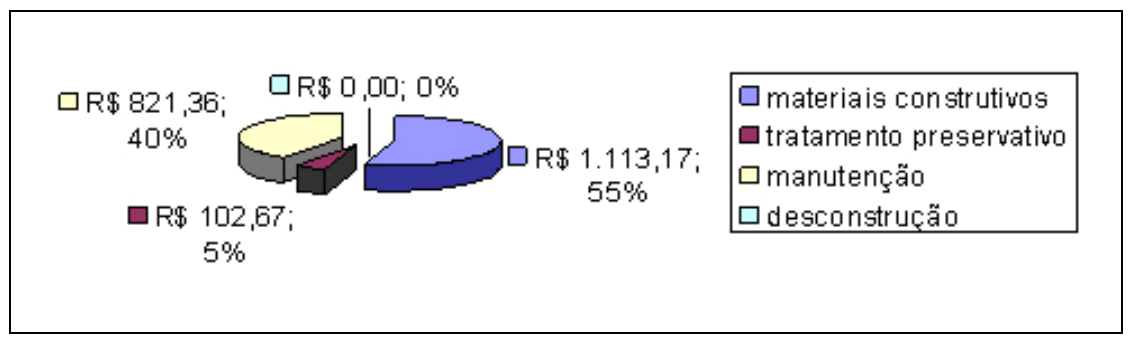

Figura 40: Custos globais do sistema estrutural de VLP ao longo do ciclo de vida. Fonte: Autor. 


\subsection{Apresentação dos dados da dimensão cultural}

Atualmente não existe nenhum método que aborda a dimensão cultural de forma clara, portanto partir-se-á da coleta de dados e questionários dos princípios e estratégias da sustentabilidade levantados no capítulo 1, 2 e 3 e das categorias de impacto já descritas anteriormente.

\subsubsection{Processo de produção florestal}

\section{I) Reavaliação do tradicional}

A empresa não se mostrou interessada em buscar antigas formas de produção, como o mutirão, principalmente considerando o seu grande porte; porém procura desenvolver e pesquisar a área de plantios florestais, atendendo as certificações ambientais que podem ser aplicadas ao seu ramo, buscando novas formas de atender o mercado e mostrando uma preocupação ambiental.

\section{II) Superação da resistência aos materiais e técnicas mais sustentáveis}

A empresa procura trabalhar com a madeira de plantios florestais que já tem uma boa aceitação no mercado nacional dentro de alguns usos.

\section{III) Recuperação de valores éticos para o planejamento da construção e assentamento}

Essa variável não se aplica aqui, pois o objeto de estudo é um sistema estrutural.

\section{IV) Internalização da sustentabilidade}

A empresa apresenta uma alta internalização da sustentabilidade, sendo esse um tema que faz parte dos cursos e atualizações oferecidos pela empresa aos seus funcionários, além de ter a certificação ambiental par seus produtos.

\subsubsection{Processo de beneficiamento da madeira}

\section{I) Reavaliação do tradicional}

A empresa apresenta um perfil mercadológico, procurando atender somente as necessidades já colocadas pelos consumidores cativos, porém trabalha com madeiras de plantios florestais, materiais renováveis, considerados por muitos autores como sustentável. Não se mostrou interessada em buscar antigas formas de produção, como o mutirão, principalmente considerando o caráter empreendedor da empresa. 
II) Superação da resistência aos materiais e técnicas mais sustentáveis

A empresa procura trabalhar com a madeira de plantios florestais dentro de um uso já consagrado no Brasil (caixaria para concreto, embalagens, etc), não apresentando interesse em uma utilização que esteja fora do ciclo de mercado.

III) Recuperação de valores éticos para o planejamento da construção e assentamento

Essa variável não se aplica aqui, pois o objeto de estudo é um sistema estrutural.

\section{IV) Internalização da sustentabilidade}

A empresa apresenta uma baixa internalização da sustentabilidade, sendo esse um tema fora das diretrizes da empresa.

4.5.3 Processo de construção do sistema estrutural de cobertura e operações de manutenção e desconstrução.

\section{I) Reavaliação do tradicional}

Todas as operações procuraram fazer uma reavaliação do tradicional, buscando em primeiro lugar utilizar as forma de produção do mutirão ou economia solidária (troca justa de serviços), mas também técnicas de construção de estruturas de madeira reavaliando seus danos potenciais e formulando propostas inovadoras dentro da perspectiva da sustentabilidade. $\mathrm{Na}$ operação de tratamento preservativo e manutenção adotou-se o método usual, sendo um ponto ainda próximo das técnicas de mercado.

\section{II) Superação da resistência aos materiais e técnicas mais sustentáveis}

Acredita-se que houve uma grande evolução na aceitação da técnica alternativa proposta, sendo que 36 das 42 habitações optaram por utilizar o sistema alternativo, representando $87 \%$ de aceitação.

III) Recuperação de valores éticos para o planejamento da construção e assentamento

Essa variável não se aplica aqui, pois o objeto de estudo é um sistema estrutural. 


\section{IV) Internalização da sustentabilidade}

Acredita-se que houve alguma internalização da sustentabilidade nesse processo, porém não houve muitas falas que reforçavam essa idéia, ficando claro que muitas vezes as escolhas se davam por fatores econômicos.

\subsection{Apresentação dos dados da dimensão política}

Assim como a dimensão cultural, atualmente não existe nenhum método que aborde a dimensão política de forma clara, portanto partir-se-á da coleta de dados e questionários dos princípios e estratégias da sustentabilidade levantados no capítulo 1, 2 e 3 e das categorias de impactos já listadas anteriormente.

\subsubsection{Processo de produção florestal.}

I) Organização das partes interessadas para conquista da participação ativa nas decisões.

A empresa não apresentou nenhuma atividade que buscasse a representação equilibrada dos trabalhadores, compondo um sistema convencional de hierarquia. Existe cooperação dentro do setor e uma preocupação com a atualização dos profissionais quanto às melhores práticas para a produção de seus produtos.

\section{II) Valores organizacionais.}

A empresa apresenta uma liberdade de associação para todos os funcionários, organizando-os para algumas pequenas tarefas como a comissão de prevenção aos acidentes e incentivando a filiação a sindicatos.

III) Cooperação para desenvolvimento de construções mais sustentáveis.

A empresa possui área específica para desenvolvimento de pesquisas visando uma maior sustentabilidade, além de já ter apresentado parcerias com universidades para esse fim.

\section{IV) Monitoramento e avaliação da própria empresa.}

A empresa possui certificações feitas por empresas externas, auditorias internas e externas, além do sistema convencional de monitoramento interno da empresa. 


\subsubsection{Processo de beneficiamento da madeira}

I) Organização das partes interessadas para conquista da participação ativa nas decisões.

A empresa não apresentou nenhuma atividade que buscasse a representação equilibrada dos trabalhadores, compondo um sistema convencional de hierarquia. Existe cooperação dentro do setor, na parceria entre as serrarias da região para a produção e venda de cavacos, reduzindo a quantidade de resíduos e gerando renda e subprodutos.

\section{II) Valores organizacionais.}

A empresa apresenta uma liberdade de associação para todos os funcionários, organizando-os para algumas pequenas tarefas como a comissão de prevenção aos acidentes.

III) Cooperação para desenvolvimento de construções mais sustentáveis.

A empresa não possui um histórico de cooperação com instituições que promovem o desenvolvimento sustentável, porém após o fornecimento da madeira de terceira para o projeto de construções populares mais sustentáveis, começou a cooperar com algumas pesquisas em andamento nessa área.

IV) Monitoramento e avaliação da própria empresa.

O monitoramento e avaliação da própria empresa sempre foram feitos internamente por funcionários contratados para cargos administrativos, porém a partir da experiência do projeto citado acima a empresa deu início a uma avaliação em parceria com a atual pesquisa e à elaboração do seu primeiro balanço social.

4.6.3 Processo de construção do sistema estrutural de cobertura e operações de manutenção e desconstrução.

I) Organização das partes interessadas para conquista da participação ativa nas decisões.

O projeto de construção das 49 habitações foi assessorado pelo grupo Habis, que colocava como meta a participação das famílias em todos os processos decisórios, criando uma experiência de troca de saberes, entre os pesquisadores e os mutirantes, em um processo pedagógico de aprendizado para as duas partes. Assim foram formadas instâncias formais para decisões coletivas 
(reuniões de comissões, reuniões de grupos e assembléias) onde todas as decisões eram tomadas democraticamente, por consenso (desejável) ou por maioria de votos. Também na marcenaria eram feitas reuniões semanais para as tomadas de decisões que caberiam à instância desse grupo.

\section{II) Valores organizacionais.}

Todos os mutirantes foram livres para participar ou não do projeto, formando-se grupos para tomadas de decisões em diferentes níveis, grupos de trabalho, comissões administrativas, de segurança, de compras, de almoxarifado, de controle de presença, entre outras; porém não foi constituído formalmente (judicialmente) nenhum grupo de associações, cooperativas, etc; ficando todos no plano informal.

\section{III) Cooperação para desenvolvimento de construções mais sustentáveis.}

Houve uma grande cooperação entre os mutirantes, mestres-de-obra da comunidade, assessoria técnica de ONGs, assessoria técnica de pesquisados de quatro universidades, governo federal (financiamento dos materiais construtivos e da pesquisa) e governo estadual (financiamento da pesquisa), envolvidos no projeto de construção das 49 habitações de forma mais sustentável.

\section{IV) Monitoramento e avaliação da própria empresa.}

O monitoramento de todo o projeto era feito não só por todos os agentes internos desse processo, através das comissões fiscais e assessorias formadas por mutirantes, como também era avaliado trimestralmente pelos agentes financiadores através de relatórios sobre andamento da obra e andamento da pesquisa, elaborados pelos assessores das universidades.

Com a apresentação dos dados e questões quantitativas e qualitativas, organizadas e divididas em suas respectivas categorias de impacto, será possível analisar os dados dentro de suas categorias e também relacioná-los, para se verificar os ganhos e perdas de sustentabilidade ao longo dos processos e entre suas dimensões. Essas análises serão feitas no próximo capítulo. 


\section{Capítulo 5}

\section{Interpretação dos dados}

A interpretação do ciclo de vida tem com objetivo analisar os resultados, elaborar conclusões, explicar limitações e oferecer recomendações, baseando-se nas constatações das fases precedentes. Pode-se dividir nas seguintes etapas:

- identificação e análise das questões significativas,

- avaliação através de: verificação de integridade / verificação de sensibilidade / verificação de consistência e outras verificações,

- elaboração de relatório com conclusões e recomendações,

- opcionalmente pode-se ainda fazer a aplicação das recomendações.

Para que a análise seja pluridimensional deve-se ainda abordar o assunto de forma holística, analisando os resultados e chegando a conclusões que considerem os ganhos e perdas das diferentes dimensões e que estejam embasadas nos princípios da sustentabilidade propostos inicialmente com a inserção dos fatores tempo e espaço, já que um dos principais pontos da sustentabilidade é a adequação do objeto ao seu meio e à sua capacidade de suporte (SILVA, S. 2000). Assim, a análise do ciclo de vida do sistema estrutural em VLP estará focada em seu contexto, assentamento rural Pirituba II, no período em que foi implantado, entre 2003 e 2006 e adotando seu tempo de vida útil de 50 anos.

Nesse capítulo serão identificadas as questões relevantes em paralelo à análise pluridimensional da sustentabilidade do objeto de estudo, que será dividida em dois grandes grupos; o primeiro analisa os impactos de cada dimensão em um processo do ciclo de vida e as possíveis relações desse com outros processos dentro da mesma dimensão, apresentados nos itens 5.2, 5.3, 5.4, 5.5 e 5.6. No segundo grupo serão feitas análises em cada processo, estudando as relações das diferentes dimensões dentro deste, sendo essas análises apresentadas nos itens 5.7, 5.8, 5.9, 5.10, 5.11. Também será feita a verificação de integridade e consistência do trabalho, procurandose identificar os pontos de dificuldades ou práticas que não se mostraram eficazes, acrescentando algumas recomendações ou sugestões para futuros trabalhos. 


\subsection{Identificação e análise das questões significativas.}

A identificação das questões significativas será feita a partir da verificação dos dados quantitativos, analisando-se os pontos de maior e menor impacto ao longo de sua cadeia pela comparação de valores absolutos, e dos dados qualitativos, que terão seus pontos significativos identificados através da contraposição de seus dados coletados com as diretrizes e indicadores propostos. Essa identificação será feita dentro de cada dimensão, considerando-se os processos e categorias, seguida de uma análise que se aproxime da pluridimensionalidade, identificando as relações entre dimensões e entre processos da cadeia produtiva e verificando como cada questão repercute nas outras questões, chegando-se assim a uma análise dos ganhos e perdas de sustentabilidade em uma dimensão e entre as dimensões, que possibilite a elaboração de cenários de maior e menor sustentabilidade.

Para facilitar a visualização e organização dessas relações criou-se uma ferramenta que relaciona as análises que serão feitas das diferentes dimensões e processos em uma mesma matriz, denominada "Matriz de análise dos resultados", cuja primeira coluna indica as diferentes dimensões da sustentabilidade que se abordará no trabalho, e a primeira linha com a seqüência dos processos e operações envolvidos no ciclo de vida do sistema de produto estudado. O cruzamento de um processo com uma dimensão gerará uma análise, que será destacada visualmente com uma linha tracejada e com uma sigla, composta por uma letra (inicial da dimensão estudada) e um número (que representa o processo), que serão utilizados para numerar os itens do texto onde essa análise será feita. A matriz também poderá ser utilizada para visualizar as relações entre diferentes processos ou dimensões, através da demarcação de uma dimensão ao longo do ciclo estudado e dos processos envolvidos na análise, preenchida com a cor verde para os processos que apresentam ganhos, vermelho para os que apresentam perdas de sustentabilidade, e amarelo para os que possuem os dois tipos de relações no mesmo processo; um exemplo pode ser visto na figura 41. 


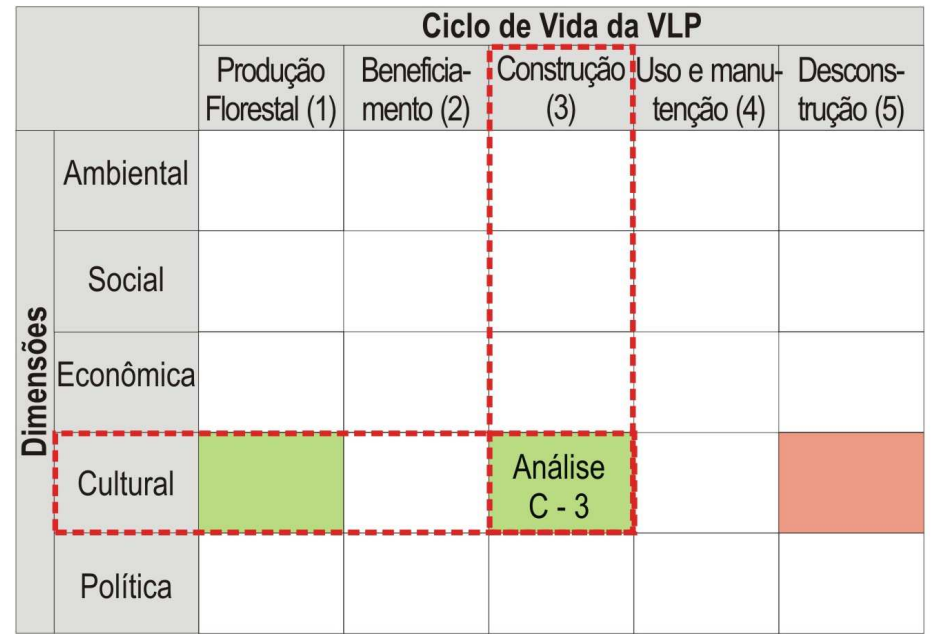

Figura 41: Exemplo da matriz de análise dos resultados.

Fonte: Autor.

Deve-se ressaltar que a utilização das cores não indica um bom ou mau desempenho de determinado processo ou dimensão de forma absoluta, mas das relações internas desse ciclo de vida (não representando também seu desempenho em relação a outros tipos de sistemas estruturais) pois, como já dito anteriormente, a sustentabilidade é um termo relativo, determinada pela comparação de duas ou mais experiências.

Assim, essa matriz será utilizada como uma ilustração ao lado do título de cada item dentro das análises que serão feitas, para facilitar a identificação de que ponto do ciclo e dimensão serão estudados e com quais eles se relacionarão, com maior ou menor sustentabilidade.

\subsection{Análise da dimensão ambiental ao longo do ciclo de vida do sistema estrutural em VLP.}

Nessa etapa serão analisados os pontos de maior e menor sustentabilidade na dimensão ambiental, seus impactos dentro de cada processo do ciclo de vida e suas relações com outros os processos. Assim, nas análises de cada processo pretende-se identificar as relações de ganhos ou perdas de sustentabilidade ao longo do ciclo de vida e suas causas.

A figura 42 mostra a matriz de análise dos dados com a indicação da análise A (ambiental) feita ao longo de todo o ciclo, indicando os números das análises e onde houve, de forma simplificada, ganhos e perdas de sustentabilidade. 


\begin{tabular}{|c|c|c|c|c|c|c|}
\hline & \multicolumn{5}{|c|}{ Ciclo de Vida da VLP } \\
\hline & & $\begin{array}{l}\text { Produção } \\
\text { Florestal (1) }\end{array}$ & $\begin{array}{l}\text { Beneficia- } \\
\text { mento (2) }\end{array}$ & $\begin{array}{l}\text { Construçãa } \\
\text { (3) }\end{array}$ & $\begin{array}{l}\text { Uso e manu } \\
\text { tenção (4) }\end{array}$ & $\begin{array}{l}\text { Descons- } \\
\text { trução (5) }\end{array}$ \\
\hline & Ambiental & $\begin{array}{c}\text { Análise } \\
\text { A-1 }\end{array}$ & $\begin{array}{c}\text { Análise } \\
\text { A-2 }\end{array}$ & $\begin{array}{c}\text { Análise } \\
\text { A - } 3\end{array}$ & $\begin{array}{c}\text { Análise } \\
\text { A- } 4\end{array}$ & $\begin{array}{c}\text { Análise } \\
\text { A - } 5\end{array}$ \\
\hline \& & Social & & & & & \\
\hline (O) & Econômica & & & & & \\
\hline & Cultural & & & & & \\
\hline & Política & & & & & \\
\hline
\end{tabular}

Figura 42: Matriz de análise dos dados com apresentação das relações da dimensão ambiental.

Fonte: Autor.

De acordo com a figura 42 pode-se notar os ganhos de sustentabilidade ambiental nos primeiros três processos do ciclo de vida, onde a utilização da madeira trouxe benefícios em todas as categorias de impacto, uso de matéria prima, energia, água e emissão de poluentes, o que porém causou uma perda de sustentabilidade nos dois últimos processos na categoria de uso de matéria prima, onde foi identificado o uso de produtos tóxicos, devido à utilização de tratamento preservativo para esse material escolhido. Essas análises serão detalhadas nos itens abaixo.

\section{Análise A-1}

\section{A questão ambiental no processo de produção}

florestal e suas relações com os outros processos do ciclo de vida.

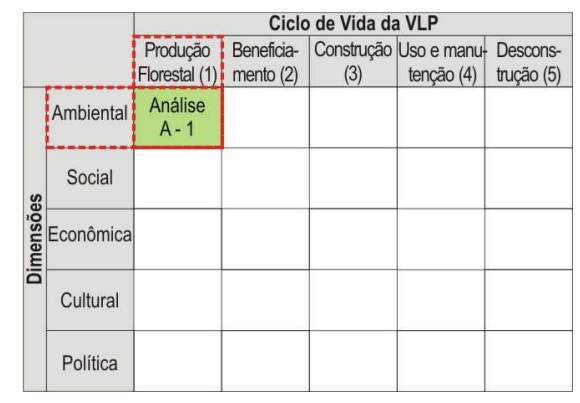

A análise $A-1$ não mostrou relações diretas com outros processos, que no entanto ainda poderão se relacionar com a produção florestal a partir das análises que serão mostradas nos itens A-2 e A-4.

No processo de produção florestal pode-se notar que na categoria de uso de matérias primas de fontes renováveis existe um fator que apresenta índice negativo $(-4708,00 \mathrm{Kg})$, referente ao consumo de toras de Pinus, indicando que, em vez de haver um consumo em massa de matéria prima, houve a produção desta durante o processo, considerando-se o crescimento das mudas ao longo dos 25 anos de ciclo de produção florestal e seu ganho de massa e volume, que estão diretamente relacionados aos ciclos de captura de carbono da atmosfera, ao consumo de 
água (ciclo hídrico) e de nutrientes do solo (ciclo geoquímico, bioquímico e biogeoquímico), BIZON (2005).

O Ciclo de captura de carbono da atmosfera tem relação direta com outro dado de índice negativo na emissão de poluentes $\left(-27.264,38 \mathrm{Kg}\right.$ de $\left.\mathrm{CO}_{2}\right)$ e significa que as árvores durante seu processo de fotossíntese capturam o $\mathrm{CO}_{2}$ da atmosfera para utilizar o carbono em seu processo bioquímico. Esse processo traz uma grande contribuição para a diminuição do índice de concentração desse gás na atmosfera, um dos principais elementos causadores do chamado efeito estufa, responsável pelo aquecimento global, amplamente debatido na atualidade. Ao somar esse índice com a emissão de $\mathrm{CO}_{2}$ das outras etapas do ciclo de vida (que no total atingem 3.110,96 $\mathrm{Kg}$ ) pode-se observar que existe um grande saldo negativo total $\left(-24153,42 \mathrm{Kg}\right.$ de $\left.\mathrm{CO}_{2}\right)$ que representa um balanço onde foi emitido menos gás carbônico durante todos os processos do que a captura durante o processo de produção florestal, resultando em um bom desempenho nas emissões de $\mathrm{CO}_{2}$, garantido pela utilização da matéria prima da produção florestal local (que exigiu apenas transportes de pequenas distâncias) e pela ausência de liberação desse gás durante os processos.

A emissão de $\mathrm{CO}_{2}$ para a atmosfera é uma questão amplamente discutida atualmente na área ambiental, e é apontada por Sachs (1993), Silva, S (2000) e CIB E UNEP-IETC (2002) como um dos principais fatores para o início da mudança de posicionamento da população mundial quanto aos temas ambientais. Nesse sentido, o objeto apresenta uma alternativa viável, dentro do contexto apresentado, para atender a demanda de matérias primas do setor da construção civil com o resgate de dióxido de carbono ao longo do seu ciclo de vida.

O Ciclo de consumo de água (ciclo hídrico) não foi quantificado, porém faz parte das pesquisas desenvolvidas pela empresa $A$, que procura não interferir nesse ciclo com suas atividades. A entrada de água considerada nesse processo é de 3,72 litros por fluxo referencial (ou por sistema estrutural de cobertura para uma habitação), sendo o segundo processo do ciclo de vida que mais utiliza água, mas que ainda pode ser considerado um consumo baixo se comparado com ciclos de vida de outros sistemas, resultando em um bom desempenho ao se utilizar racionalmente os recursos esgotáveis, colocado por Silva, S (2000) e Yuba (2005) como uma importante diretriz ambiental.

Sobre o Ciclo de consumo de nutrientes do solo, Kronka et al (2005) coloca que, apesar dos plantios de Pinus estarem na maioria das vezes ligados a áreas de solos pobres e sem tratos 
silviculturais de controle dos nutrientes do solo, é necessário atentar para o balanço nutricional dessas áreas.

Bizon (2005) faz um estudo de entradas e saídas de nutrientes em diferentes tipos de solo e chega a conclusões que indicam que os plantios de Pinus conseguiriam manter suas atividades por mais tempo sem a reposição de nutrientes se utilizassem a técnica de cultivo mínimo, que segundo o mesmo autor consiste em não retirar as acículas, galhos e raízes do local após a colheita e não realizar a usual prática de queimada. Isso faria com que houvesse uma maior reposição dos nutrientes pela decomposição, permitindo assim uma média de 25,6 ciclos de plantio e colheita de 25 anos, totalizando no máximo 640 anos de cultivo em uma mesma área para só então zerar o estoque de nitrogênio e fósforo, nutrientes considerados críticos por se concentrarem nas toras que são "exportadas" do local durante a colheita do Pinus. O autor indica que para um manejo sustentável do solo é necessária a reposição de nutrientes na etapa de plantio do Pinus, em praticamente todos os tipos de solo, devendo cada caso ser estudado em particular.

No objeto de estudo, o processo florestal aproxima-se do cultivo mínimo, pois, além da não utilização da prática de queimada, os resíduos gerados nesse processo (acículas, galhos e raízes) são deixados no solo em sua íntegra. Verifica-se também como uma das entradas o adubo à base de fosfato $(300 \mathrm{Kg} / \mathrm{ha}$ ), ainda que haja a necessidade de um estudo mais aprofundado sobre o tipo de solo e o adubo utilizado para que se possa determinar a quantidade de ciclos que poderão ser realizados. No entanto, pode-se acrescentar que além do cultivo mínimo e da utilização de adubação à base de fosfato, um manejo adequado de outros nutrientes pode aumentar a produção por tempo indeterminado em uma mesma área.

A partir da análise feita, esse trabalho demonstra a perspectiva de produção ilimitada da madeira como matéria prima, considerada por Partel (2005) um recurso renovável com capacidade de atender a população ao longo de suas gerações, ao contrário de recursos como o aço ou cimento (que têm como matéria prima jazidas minerais com vida útil já pré-estabelecida para se esgotarem, apesar da abundância), abordando-se assim um dos primeiros conceitos da sustentabilidade, sua durabilidade ao longo do tempo.

Dentro das emissões do processo de produção florestal não foram calculadas as emissões para água ou solo, porém vale ressaltar que alguns autores como Mahmoud, A. G. E.; et al (200-) sugerem um estudo sobre a produção de alelopáticos por algumas espécies de Pinus, cuja definição é "a capacidade que as plantas têm de interferir na germinação de sementes e no 
desenvolvimento de outras, por meio de substâncias que estas liberam na atmosfera ou, quase sempre, no solo" (MEDEIROS,1990 apud Azevedo 2007).

Alguns estudos foram feitos sobre o efeito dos extratos etanólicos (substâncias alelopáticas) do Pinus Elliottii e do Eucalipto Citriodora sobre a germinação e o crescimento inicial de outras espécies. Ferreira et al (2007) analisa esse efeito sobre o Bidens Pilosa L. (picão-preto), e Azevedo (2007), sobre a Lactuca Sativa L. (alface), considerada uma das espécies mais sensíveis aos metabólitos secundários, e ambos chegam à conclusão de que somente o Eucalipto Citriodora tem influência na porcentagem de sementes germinadas e na sua velocidade de germinação, não sendo identificada nenhuma interferência do extrato de Pinus Elliottii. Também foram medidas as taxas de crescimento radicular da alface do picão-preto em exposição aos extratos etanólicos e Azevedo (2007) encontrou interferência somente do Eucalipto Citriodora no crescimento do alface, enquanto que Ferreira et al (2007) não detectou interferência do Pinus nem do Eucalipto.

A bibliografia sobre as emissões de alelopáticos da espécie de Pinus é bastante restrita, havendo a necessidade de um estudo mais aprofundado sobre esse tópico, porém a partir do material encontrado conclui-se que não há de emissões alelopáticas pela espécie de Pinus Elliottii.garantindo um bom desempenho para esse processo quanto às diretrizes ambientais de "Preservação da Diversidade da Vida", já que esse não interfere na biodiversidade do ecossistema, indicador colocado por Silva, S (2000) e Yuba (2005) como sendo uma das diretrizes da dimensão ambiental.

\section{Análise A- 2}

\section{A questão ambiental no processo de beneficiamento}

e suas relações com os outros processos do ciclo de vida.

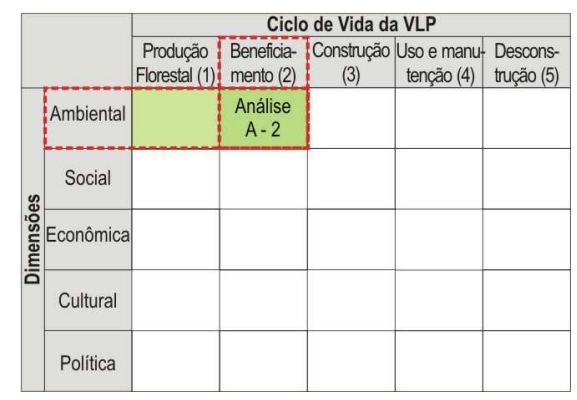

No processo de beneficiamento da madeira verificam-se os maiores índices de geração de resíduos, referentes à produção de pó-de-serra e de cavacos $(921,66 \mathrm{Kg}$ e 1472,58 $\mathrm{Kg}$ respectivamente), que no entanto têm potencial de re-uso e são utilizados como matéria prima em outros processos. Todo o pó-de-serra é utilizado inicialmente para forração de granjas e haras e em seguida como adubo em plantações, retornando os seus nutrientes para o solo, enquanto que os cavacos são queimados para geração de energia calorífica em outras indústrias e na 
caldeira da própria serraria, para a secagem de outras madeiras; porém, deve-se ressaltar que, no objeto de estudo, a madeira de Pinus foi secada naturalmente, utilizando-se energia solar para reduzir o seu teor de umidade, e por isso não se considerou o consumo de energia calorífica da queima do cavaco nesse processo. Outra consideração importante é o índice negativo do consumo de energia calorífica, gerada $(2645,79 \mathrm{KWh}$ provenientes da queima dos cavacos) em maior quantidade que é consumida (3,04 KWh provenientes de combustíveis fósseis), devido às curtas distâncias percorridas no transporte entre os processos (em geral de matérias primas).

O consumo de energia elétrica nesse processo também é o mais alto do ciclo de vida $(114,34$ KWh), porém ainda muito inferior à possibilidade de geração de energia elétrica a partir da energia calorífica produzida com a queima do cavaco, utilizando-se a conversão de $1 \mathrm{KWh}$ de energia elétrica para 3,64 KWh de energia calorífica sugerida por Mafra (2007). Para se gerar energia calorífica com a queima do cavaco, emite-se $\mathrm{CO}_{2}$ na atmosfera $(1003,43 \mathrm{Kg}$ emitidos nesse processo) que, no entanto, pode ser absorvido pela captura de $\mathrm{CO}_{2}$ da produção florestal, acarretando em uma avaliação de ganhos de sustentabilidade nessa questão por ambos os processos.

A preocupação em se discutir a utilização de energia está intrinsecamente ligada à questão do consumo de combustíveis fósseis, colocada por CIB E UNEP-IETC (2002) e Sachs (1993) como fundamental para a discussão de sustentabilidade e dos padrões de consumo atuais, relacionados diretamente aos conflitos e disputas por recursos naturais. Assim, com a utilização da madeira como fonte de energia renovável, tem-se uma alternativa mais sustentável para geração de energia, pois pode ser produzida em abundância na maioria dos países e posteriormente transformada em energia elétrica, possibilitando usos mais diversificados.

O consumo de água também tem seu maior índice no processo de beneficiamento (6,98 litros), que ainda assim pode ser considerado muito baixo se comparado ao consumo em outros processos de sistemas construtivos, não representando grande impacto dentro de um ecossistema. Uma medida que está sendo tomada pela empresa e que garantirá melhores índices de sustentabilidade nessa categoria é a implantação de um sistema de captação de águas pluviais em substituição ao poço artesiano, utilizado como fonte de água para esse processo. 
Análise A- 3

\section{A questão ambiental no processo de construção e suas relações com os outros processos do ciclo de vida.}

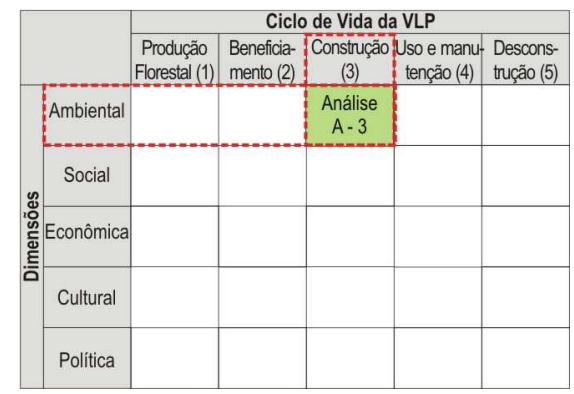

O processo de construção é o processo que mais tem entradas de matérias primas de fora da fronteira do sistema definido $(120,97 \mathrm{Kg})$, representando $6,55 \%$ da massa do sistema estrutural, sendo todos os 93,45\% restantes referentes à madeira de Pinus de terceira qualidade, resultando em uma alta sustentabilidade ambiental nessa categoria.

Os resíduos desse processo são gerados na operação de pré-fabricação, e todos são transformados em produtos para processos de outras cadeias, garantindo assim o bom desempenho nessa categoria A madeira de $3^{\text {a }}$ qualidade refugada e os refilos $(327,40 \mathrm{Kg}$ ) foram utilizados para outros fins dentro do próprio assentamento, o pó-de-serra $(258,47 \mathrm{Kg}$ ) foi vendido para forração de granjas. A iniciativa de se pensar em um fim para os resíduos gerados é considerada por Yuba (2005) essencial para que haja uma maior sustentabilidade, onde os produtos e resíduos não devem mais ser simplesmente descartados no fim dos seus processos, gerando impactos negativos, mas devem ser reutilizados ou reciclados. Assim, essa categoria foi avaliada com um bom desempenho, estando em conformidade com as diretrizes levantadas da sustentabilidade.

Considerando que grande parte do processo de construção foi pré-fabricado, a operação de montagem teve menor geração de resíduos $(0,80 \mathrm{Kg}$ de aço em forma de pregos tortos) e menor gasto energético $(0,12 \mathrm{KWh}$ contra $23,94 \mathrm{KWh}$ da pré-fabricação), e isso se deve à estratégia de concentrar as operações mais complexas dentro de um único espaço (marcenaria) para que houvesse maior controle e precisão da execução, evitando o desperdício de materiais e energia em canteiro de obra. Destaca-se também que durante a pré-fabricação e montagem do sistema construtivo não se utiliza água, e que a emissão de poluentes ao ar é uma das mais baixas, mostrando o alto grau de sustentabilidade ambiental da operação dentro desse ciclo de vida, como já discutido anteriormente para a categoria de uso de energia. 
Análise A- 4

\section{A questão ambiental nas operações de uso e manutenção e suas relações com os outros processos do ciclo de vida.}

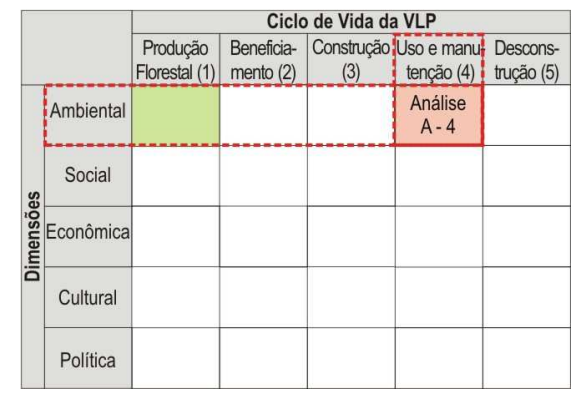

A operação de uso não poderá ser avaliada por se tratar de um sistema estrutural, porém essa análise deve ser feita ao se considerar o estudo de edifícios, pois estes podem apresentar um grande consumo energético e de água, ao longo de sua vida útil.

$\mathrm{Na}$ operação de manutenção destaca-se a utilização de $0,14 \mathrm{Kg}$ de cipermetrina, (fórmula empírica $\mathrm{C}_{22} \mathrm{H}_{19} \mathrm{Cl}_{2} \mathrm{NO}_{3}$ ) que, apesar de representar uma baixa quantidade em massa para a manutenção do sistema estrutural durante os 50 anos de sua vida útil, é um material tóxico. Estudos do INTERNATIONAL PROGRAMME ON CHEMICAL SAFETY (1995) e o FOOD AND AGRICULTURE ORGANIZATION OF THE UNITED NATIONS (1985) mostram o uso recorrente dessa substância em países da Europa e Ásia como pesticida em alguns cultivos (chá, pêssego, nectarina e uva) e colocam como IDA (ingestão diária aceitável) 0,05 mg cipermetrina / kg p.c. (peso do corpo), porém não fornecem informações sobre os índices aceitáveis para se depositar a substância no solo ou para sua utilização como preservativo de madeiras. Os estudos para a regulamentação da cipermetrina no Brasil foram feitos pela ANVISA (Agência Nacional de Vigilância Sanitária, 2007) e prevêem a possibilidade de aplicação do produto no tratamento preservativo de madeiras, além de outras culturas (algodão, amendoim, arroz, batata, café, cebola, ervilha, feijão, feijão-vagem, fumo, melancia, milho, pepino, repolho, soja e tomate) com o mesmo IDA de $0,05 \mathrm{mg} / \mathrm{Kg}$ p.c., sem entretanto avançar nos estudos dos impactos ambientais, encontrados somente para um outro produto com princípio ativo de cipermetrina com 30\% de concentração, contra 1\% do tratamento utilizado, apresentando os seguintes dados:

- Mobilidade: praticamente imóvel no solo.

- Persistência: moderada (1/2 vida $2-4$ semanas, solo).

- Degradação: ação bacteriana e fotólise; hidrólise em meio neutro.

- Toxicidade para peixes: pode ser altamente tóxico dependendo da espécie.

- Toxicidade para invertebrados aquáticos: altamente tóxico (CL50 entre 0,004 e 3,6 mcg/L).

- Toxicidade para aves: praticamente não tóxico (DL50 oral entre 5000 e 10000 mg/kg).

- Toxicidade para minhocas: não disponível. 
- Toxicidade para abelhas: pode ser altamente tóxico.

- Alta afinidade por matéria orgânica do solo e na água - adsorção alta - Log Pow = 5,0

- Baixo potencial para bioacumulação (FBC=17), FERSOL (2004)

O produto utilizado como tratamento preservativo de madeira, é regulamentado pelo IBAMA dentro da classe de toxicidade IV (produto pouco perigoso para seres humanos), e dentro da classe de risco ambiental II (produto muito perigoso), BRASIL (2007). A disposição final dos produtos contaminados da construção civil é regulamentada pela resolução 307 do CONAMA (2002), para que não haja emissões para cursos d'água, lençol freático ou mesmo solo, assunto que será abordado no item de disposição final.

De forma geral, mesmo atendendo aos requisitos legislativos, pode-se adotar um baixo grau de sustentabilidade dessa operação, pois todos os materiais contaminados devem ser dispostos em aterro industrial, colocado por Yuba (2005) como uma prática como não desejável para materiais construtivos. Para o aumento da sustentabilidade nessa questão, poderiam ser feitos estudos e análises futuras de outros tratamentos preservativos para a madeira que apresentassem baixos impactos ambientais e baixa toxidade para o homem.

A necessidade de se utilizar tratamento preservativo nesse sistema estrutural deve-se à escolha da espécie plantada no processo florestal para fornecimento da matéria prima. A madeira de Pinus tem baixa densidade, e por isso é mais suscetível ao ataque de insetos xilófagos do que espécies dicotiledôneas; assim a norma ABNT 7190 recomenda a utilização do tratamento preservativo em autoclave para esse tipo de madeira (espécies coníferas), aumentando a durabilidade do sistema estrutural e evitando seu comprometimento estrutural ou mesmo ruína por ataques de insetos.

Sobre o plantio de Pinus no Brasil (principalmente a var. Elliottis), Ziller (2000) destaca a sua facilidade de adaptação quando introduzida em outros ambientes, reproduzindo-se em quantidade suficiente para ocupar o espaço de espécies nativas e produzir alterações nos processos ecológicos naturais, tendendo a tornar-se dominante, sendo assim considerada uma espécie exótica invasora. Esse entendimento é reforçado pelos trabalhos de Bourscheid et al (200-) e Mahmoud et al (200-) que também estudam casos da interferência dessa espécie em ambientes frágeis no Brasil, porém Ziller (2000) coloca que o Pinus apresentou potencial invasor “[...] em áreas abertas, sejam degradadas ou naturalmente ocupadas por vegetação herbáceoarbustiva. [...] [...] O gênero não se caracteriza, portanto, como invasor de formações florestais", e acrescenta que "é fundamental ressaltar que não são as atividades econômicas (plantio do Pinus) 
em si responsáveis pela degradação ambiental geral da estepe gramíneo-lenhos (objeto estudado), mas sim a forma como são desenvolvidas".

Assim, a autora propõe alguns procedimentos para minimizar os efeitos da invasão do Pinus:

- Definir o formato dos povoamentos florestais de acordo com características locais de relevo, posição dos cursos d'água e direção dos ventos para maximizar a dispersão de sementes dentro dos próprios povoamentos.

- Estabelecer ao redor dos povoamentos florestais três faixas de quebra-vento com espécies não invasoras a fim de reduzir a dispersão de sementes;

- Dar preferência ao estabelecimento de povoamentos florestais em meias encostas, a fim de evitar a formação de sítios de disseminação em topos e vales;

- Manter e/ou restaurar florestas de galeria como medida de proteção à disseminação de sementes por cursos d'água;

- Estabelecer processos de certificação ambiental para a região, previstos a prevenção, o controle e o monitoramento da dispersão natural de plantas invasoras.

- Restringir o uso do gênero Pinus a áreas com maior chance de não contaminação.

No objeto de estudo são colocadas em prática algumas recomendações propostas pela autora, tais como a preservação de florestas nativas em áreas de galeria e a certificação ambiental pela FSC e pela ISO 14001, que regulamentam áreas de preservação permanente, controle de fauna e flora nativas, além do controle de invasão da espécie em outras áreas, feito através da visita de vigilantes que fazem controle mecânico da contaminação, não só de Pinus, mas também de outras espécies (como o eucalipto) provenientes de outras áreas.

Assim, considerando as diretrizes ambientais colocadas por Silva, S (2000), "preservação da diversidade da vida", e que a contaminação biológica pode interferir na biodiversidade do ecossistema, avaliar-se-á esse processo com um desempenho satisfatório, por ter garantido a implantação em áreas adequadas e a não contaminação de áreas vizinhas através de processos mecânicos e projetos de pesquisa, como requerem as certificações ambientais concedidas.

Coloca-se então, para futuros trabalhos, a possibilidade de se estudar espécies nativas que atendam as exigências desse ciclo de vida do sistema estrutural proposto e que não tenham comportamento de plantas invasoras, diminuindo esse risco potencial e evitando medidas preventivas de alto custo econômico. 
Análise A- 5

\section{A questão ambiental na operação de desconstrução e disposição final e suas relações com os outros processos do ciclo de vida.}

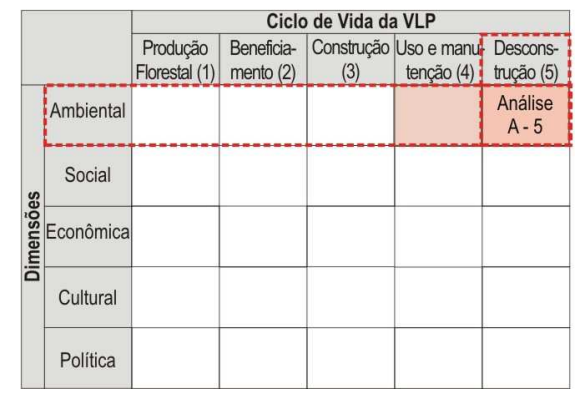

A contaminação da madeira nas operações de manutenção e tratamento preservativo tem uma conseqüência diretamente ligada à operação de disposição final, considerando o caráter tóxico do produto utilizado que contamina toda a madeira do sistema estrutural, que por sua vez não pode ser lançado ao solo em sua desmontagem pelo perigo da lixiviação da cipermetrina (principio ativo do tratamento preservativo) para o solo ou água, causando danos ambientais. Portanto foi prevista sua disposição final em aterro industrial devidamente preparado, seguindo orientações do próprio fabricante do produto preservativo, para então considerar nulas as emissões para solo e água. Segundo o art. 13 da resolução CONAMA 307 (CONAMA 2002) de 17/07/2002, todos os municípios deveriam cessar a disposição de resíduos de construção em aterros sanitários e passar a dispô-los em aterros devidamente preparados no prazo máximo de 18 meses, porém, o aterro industrial regularizado pela CETESB (órgão responsável pela legalização e fiscalização dos aterros) mais próximo do assentamento Pirituba II situa-se no município de Sorocaba - SP, a uma distância de $227 \mathrm{Km}$, que aliada à necessidade de se fazer o transporte dos componentes em caminhões - que não utilizarão toda a sua capacidade de carga e retornarão vazios - tem-se a maior emissão de poluentes ao ar (incluindo o $\mathrm{CO}_{2}$ ) de todos os processos do ciclo de vida, gerada pelo consumo de combustíveis fósseis. Assim, acredita-se que tanto o gasto energético, quanto os altos níveis de poluentes ao ar emitidos nessa operação poderiam ser reduzidos caso a prefeitura implementasse no município de Itapeva um aterro industrial para os resíduos da construção, evitando que essa disposição fosse feita em municípios vizinhos.

Partindo-se então das diretrizes colocadas pelos autores nas análises dos processos anteriores, pode-se classificar esse processo com uma baixa sustentabilidade ambiental na categoria de emissões, considerando-se o risco de contaminação por lixiviação de produtos tóxicos e a alta emissão de poluentes ao ar. 


\section{3 - Análise da dimensão social ao longo do ciclo de vida do sistema estrutural em VLP.}

O estudo da questão social será feito a partir da análise comparativa da ponderação já aplicada e dos dados qualitativos levantados, procurando-se fazer as análises através dos indicadores propostos pelo método utilizado e identificando-se as relações de ganhos e perdas de sustentabilidade ao longo da avaliação de cada processo, assim como na dimensão ambiental.

Também será utilizada a matriz de análise dos dados para ilustrar as relações existentes ao longo do processo e em cada análise individual (figura 43).

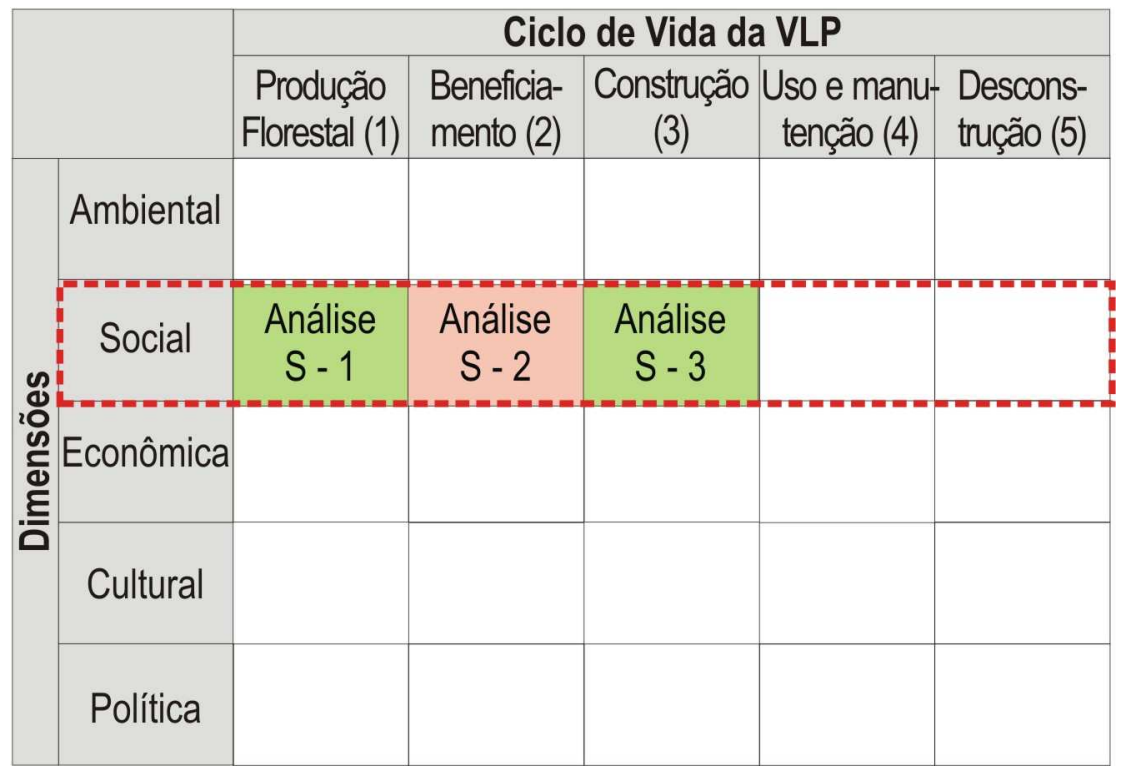

Figura 43: Matriz de análise dos dados com apresentação das relações da dimensão social.

Fonte: Autor.

\section{Análise S - 1}

A questão social no processo de produção florestal e suas relações com os outros processos do ciclo de vida.

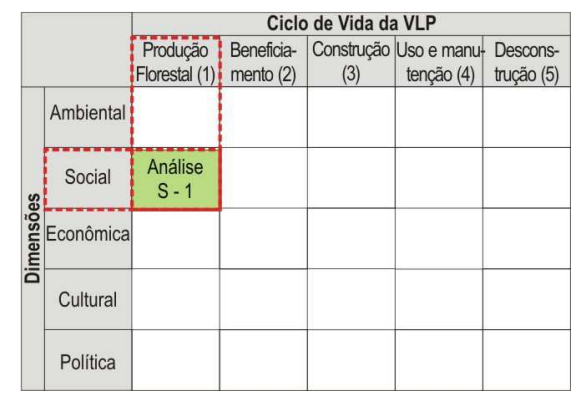

A empresa de produção florestal foi a que obteve um maior desempenho social em todo o ciclo de vida, apresentando os melhores índices em 4 dos 6 temas propostos. O bom desempenho nesses temas está relacionado à proposição de políticas claras, e implementação de projetos e 
ações que seguem os padrões internacionais propostos por entidades que regulamentam questões relativas à qualidade de produtos e serviços, como a ISO 9000 e 14001 e SA 8000, que também abordam temas como a qualidade de vida dos funcionários, relações da empresa com fornecedores e consumidores, busca da não discriminação racial e de gênero, entre outras.

Com relação ao tema Público Interno as iniciativas que fizeram a empresa alcançar um bom desempenho foram: programa de benefícios que atingem $11,71 \%$ de sua renda líquida, incluindo participação nos lucros, programas especiais de saúde (ambulatório médico nas plantas industriais, cursos especiais para gestantes e familiares, programa médico especial para funcionários que irão aposentar, entre outros) e bolsas de estudo fora do treinamento profissional (para cursos técnicos, pré-vestibular, ensino superior e pós-graduação), além de programas de lazer e cultura.

Destaca-se que a empresa coloca a questão socioambiental como um dos seus princípios, implementando-a não somente em projetos financiados externamente, mas incorporando-a em seus produtos e serviços, além de exigir dos fornecedores os mesmos padrões de qualidade colocados internamente e fazendo verificações de seu cumprimento. A alta ponderação nesses temas, 8,8 em Valores Internos e Governança, 7,2 em Público Interno, 9,2 em Fornecedores e 10 em Consumidores, só puderam chegar a esses níveis devido à existência de auditorias externas, que fazem a conferência de forma imparcial para que as certificações possam ser dadas.

O principal ponto para que se resultassem em menores índices em Valores Internos e Governança e em Público Interno, foi a não participação de todos os funcionários na elaboração das estratégias, princípios e valores da empresa e em sua avaliação e controle, sendo essas responsabilidades de cargos executivos e de diretores, além da adoção de políticas de mercado com a concorrência e a não existência de ações afirmativas contra a discriminação de raça e gênero.

Com relação aos temas Comunidade e Governo e Sociedade, a empresa apresentou o segundo melhor desempenho, com as ponderações de 7,5 e 4,9, respectivamente. Com relação à Comunidade a empresa apresentou um bom indicador em voluntariado, apresentando programas formais para incentivo dos funcionários, porém seus projetos, com exceção dos projetos ambientais, não são pró-ativos, aparecendo de forma assistencialista e sem planejamentos de longa duração visando sua auto-suficiência. O tema Governo e Sociedade foi o de menor pontuação devido a práticas usuais de mercado no tocante a doações para campanhas políticas, 
além de promover a cidadania apenas periodicamente com os funcionários, não os incentivando a uma atuação política ativa em sua comunidade.

De forma geral a empresa tem uma posição de destaque dentro do seu ramo e procura estar ligada a entidades que pesquisam e implementam ações socioambientais, utilizando ferramentas como o balanço social do Instituto Ethos, onde é considerada benchmarking (padrão a ser seguido) em relação aos temas Consumidores e Meio Ambiente.

No geral a empresa possui um bom desempenho social, pois atinge bons resultados na diretriz “combate das práticas de exclusão, discriminação e reprodução da pobreza, respeitando-se a diversidade em todas as formas de expressão" colocadas por Silva, S (2000) e Yuba (2005). Entretanto, apesar de apresentar boa pontuação em algumas questões, estas não refletem as diretrizes colocadas pelas autoras, como o "aumento da qualidade de vida da população dos países subdesenvolvidos", pois a empresa oferece melhorias na qualidade de vida dos funcionários, porém estes não têm um perfil de população excluída, sendo sua maioria homens, alfabetizados e brancos, que vivem dentro de uma cidade de alto IDH.

\section{Análise S - 2}

\section{A questão social no processo de beneficiamento da madeira e suas relações com os outros processos do ciclo de vida.}

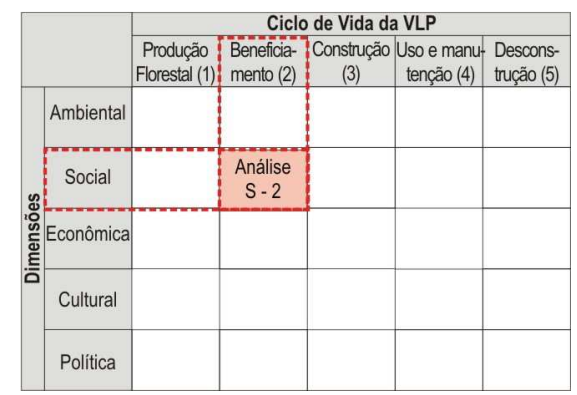

A empresa que faz o processo de beneficiamento da madeira apresentou os menores índices de desempenho social de todo o ciclo de vida. Quanto ao tema de Valores Internos e Governança constatou-se que a empresa possui um documento escrito sobre seus princípios, que no entanto não aborda nenhuma questão ética, como a discriminação ou termos de conduta dentro da empresa, somente a questão de novas fontes de energia, além das questões usuais de mercado e de qualidade do produto. Verificou-se também que o documento não tinha ampla divulgação interna e nenhuma divulgação externa, não sendo auditado por membros internos nem externos para averiguação de seu cumprimento. Com relação à governança todas as decisões estratégicas são tomadas pelos proprietários do empreendimento não havendo qualquer tipo de participação dos trabalhadores ou mesmo dos cargos de chefia, além dessas não serem divulgadas internamente após serem definidas. 
Quanto ao Público Interno observou-se que a empresa se preocupava em cumprir as exigências legais em vigor, com pagamento de benefícios e encargos exigidos usualmente, adotando a mesma prática para os temas de Fornecedores, Consumidores e Governo e Sociedade, nas quais apresenta ponderações sempre abaixo de 3,5. O melhor índice da empresa foi relativo à comunidade, nota 4, por apresentar projetos sociais de iniciativa própria visando a melhoria de qualidade de vida da comunidade local e das crianças, além de incentivar o trabalho voluntário dos funcionários.

De forma geral nota-se que o baixo desempenho da empresa dentro do método de Indicadores do Instituto Ethos não esteve ligado ao não cumprimento das leis vigentes para o mercado e trabalhadores, sendo essas cumpridas na íntegra, mas pela falta de iniciativa na elaboração de projetos e ações visando mudar a forma como as relações entre empresa, trabalhadores, fornecedores, consumidores, governo, sociedade e comunidade são estabelecidas atualmente. Assim, pode-se observar que o tema de Relações com a Comunidade Local teve índices mais altos, decorrentes das iniciativas que vão além das obrigações legais da empresa, exemplo que reforça a necessidade de mudança, nas relações de mercado atuais para se conseguir um bom desempenho social, praticando ações que visem melhorias na qualidade de vida dos atores, envolvendo todas as partes nos processos decisórios e baseando-se em diretrizes socioambientais. Entretanto no geral, considerando-se o não atendimento das diretrizes sociais colocadas na literatura, a empresa apresentou uma baixa sustentabilidade nessa dimensão.

\section{Análise S - 3}

A questão social no processo de construção e suas relações com os outros processos do ciclo de vida.

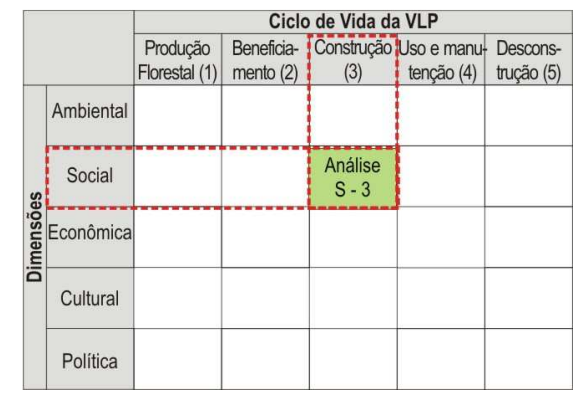

Como já explicado anteriormente, no processo de construção do sistema estrutural os componentes foram pré-fabricados na marcenaria coletiva Madeirarte e montados em canteiro por outros mutirantes, através da troca de serviços. Assim, a análise social poderá ser feita a partir do método de indicadoteres Ethos-SEBRAE aplicado na marcenaria Madeirarte e da análise das relações de trocas de serviços com os mutirantes que trabalharam na etapa de montagem.

O empreendimento atingiu as melhores pontuações em 2 dos 6 temas propostos, Comunidade com 8,2 pontos e Governo e Sociedade com 5,7 pontos; índices atingidos pelo bom desempenho nos indicadores Gerenciamento do Impacto da Empresa na Comunidade do Entorno, Relações 
com a Comunidade do Entorno, Participação Comunitária e Benefícios para o Negócio a partir da Ação na Comunidade, dentro do tema Comunidade, e Participação e Influência Social, no tema Governo e Sociedade.

Nos indicadores Gerenciamento do Impacto da Empresa na Comunidade do Entorno, Relações com a Comunidade do Entorno e Participação e Influência Social, o bom desempenho se deu principalmente pela escolha proposital da implantação do empreendimento em uma comunidade carente, como apresentado no capítulo 2, que, ao contrário da prática usual de mercado que procura minimizar os impactos negativos gerados, visava a melhoria de qualidade de vida da comunidade, possibilitando o acesso à habitação $\left(\right.$ de $\left.75 \mathrm{~m}^{2}\right)$ utilizando-se esquadrias e sistema estrutural de cobertura em madeira (normalmente não utilizada em habitações populares) préfabricados na marcenaria coletiva implantada. O alto desempenho das relações deve-se também à ação da universidade com a comunidade, e não da universidade para a comunidade em uma posição passiva; pelo contrário, a iniciativa partiu das próprias famílias na demanda por habitações ao ITESP (ver capítulo 2), que participaram não só na implementação e construção das habitações e do sistema estrutural de cobertura, mas nas decisões de todo o processo, resultando em um bom desempenho no indicador de Participação Comunitária.

A concretização da marcenaria deve-se à iniciativa das famílias da comunidade como forma de viabilizar a pré-fabricação de componentes construtivos para as habitações, e essa questão está diretamente relacionada ao bom desempenho do indicador Benefícios para o Negócio a partir da Ação na Comunidade por priorizar a participação desta nas escolhas e implementação de seus próprios projetos, que neste caso contribuiu para a geração de trabalho e para o aumento significativo na renda de seus integrantes, possibilitando a continuidade da marcenaria, atendendo prioritariamente as demandas da comunidade e de outros assentamentos rurais.

No tema de Governo e Sociedade, a marcenaria atingiu somente 50\% do que poderia ser apontado como melhor desempenho, e ainda assim obteve valor mais alto em relação às outras empresas. De maneira geral nenhuma delas prioriza o processo de educação política de seus colaboradores, com ações práticas e formais que procuram incentivá-los a participar ativamente de atividades políticas. A iniciativa mais evidente foi o incentivo à comunidade de cobrar seus direitos das autoridades locais (como ITESP e INCRA), feita esporadicamente, não chegando a caracterizar uma diretriz de ação do empreendimento. Esse quadro poderia melhorar se as empresas tivessem, em documentos formais, propostas de ações contínuas de esclarecimento da importância da participação política e de incentivo ao aumento de cidadania. 
O empreendimento está estruturado de forma que quaisquer decisões estratégicas, tanto do mutirão quanto da marcenaria coletiva, eram tomadas em reuniões ou assembléias abertas a todos os integrantes, onde todos ou pontos de pauta eram discutidos e esclarecidos antes que os mesmos propusessem o encaminhamento final para votação. Esse tipo de prática favoreceu a alta pontuação nos indicadores referentes à governança do tema Valores e Governança, pois permitiu que não só as decisões práticas fossem tomadas de acordo com os interesses dos assentados, como também as diretrizes, princípios e valores do empreendimento. Uma maior pontuação não foi atingida no tema de valores, pois o código de conduta da marcenaria e do mutirão não aborda de forma clara e com mecanismos formais temas importantes como avaliação de fornecedores e penalidades para práticas de corrupção e propinas.

No tema de Público Interno a marcenaria coletiva atingiu a pontuação de 6,2, com os melhores índices nos indicadores referentes à Formação Profissional, Acesso à Informação, Promoção de Eqüidade, Critérios de Contratação e Valorização da Diversidade. Em relação aos Critérios de Contratação, Valorização da Diversidade e Promoção da Eqüidade, o projeto em estudo trata diretamente de uma população historicamente discriminada, em especial no caso da marcenaria coletiva, formada inicialmente por três mulheres, sendo uma delas negra, com mais de 45 anos, com o ensino fundamental ou médio incompleto, de uma comunidade onde $86 \%$ das famílias têm renda inferior a 2 salários mínimos, destacando-se as relações de gênero que muitas vezes não são levadas em consideração e que nesse caso estavam em pauta, salientadas pela fala do marceneiro instrutor: "ter mulher trabalhando em marcenaria é uma coisa que eu nunca vi". Assim, as questões de gênero, renda, escolaridade e raça foram sendo colocadas como parte das discussões da marcenaria, mesmo sem uma política formal de debate e encaminhamentos, construindo-se uma prática que resultou em melhores indicadores quantitativos em relação aos outros empreendimentos do ciclo de vida estudado.

Os desempenhos mais baixos, ainda nesse mesmo tema, foram nos indicadores relativos a Benefícios Adicionais dos Funcionários, Relação com Sindicatos e Inclusão de Deficientes, sendo que, durante o período de implementação do empreendimento tanto os benefícios adicionais quanto os exigidos por lei não foram garantidos aos mutirantes e aos trabalhadores da marcenaria, que possuíam apenas um fundo coletivo capaz de suprir, em parte, alguns desses benefícios. $O$ empreendimento apresentava esse quadro pois não estava devidamente regulamentado e dessa maneira seus trabalhadores não tinham seguro que cobrisse acidentes de trabalho, previdência social e nem eram filiados a sindicatos. 
Para que esse problema social seja minimizado, poder-se-ia haver avanços nesse tipo de programa habitacional que oferecesse melhores condições de trabalho e habitações de qualidade à população dessa faixa de renda, prevendo a regulamentação dos trabalhadores nesse tipo de empreendimento ou propondo novos programas habitacionais.

No tema Fornecedores o processo de construção obteve seus piores resultados, pois se baseou somente em critérios de mercado, como preço, qualidade e prazo de entrega. Nota-se que esse foi o mesmo padrão adotado pela empresa responsável pelo beneficiamento da madeira, porém tiveram pontuações diferentes (2,9 e 1,4 respectivamente), já que os indicadores Ethos-SEBRAE e Ethos exigem um melhor desempenho das grandes e médias empresas, considerando algumas variáveis (como os recursos acumulados e a infra-estrutura consolidada) que minimizam as distorções ao compará-las.

De forma geral esse processo apresentou um atendimento a todas as diretrizes e metas que deveria ser alcançada para haver um bom desempenho social: "viabilização de uma maior equidade de riquezas e de oportunidades" e "aumento da qualidade de vida da população dos países subdesenvolvidos, combatendo-se as práticas de exclusão, discriminação e reprodução da pobreza e respeitando-se a diversidade em todas as formas de expressão".

\subsection{Analise da dimensão econômica ao longo do ciclo de vida do sistema estrutural em VLP.}

A análise da dimensão econômica será feita a partir dos dados qualitativos levantados e dos dados quantitativos dos três indicadores propostos: Produtividade, Investimentos e Geração e Distribuição de Riqueza, utilizando a mesma ferramenta já citada nos outros itens e identificando-se as relações de ganhos e perdas dentro das avaliações de cada processo. 


\begin{tabular}{|c|c|c|c|c|c|c|}
\hline & \multicolumn{5}{|c|}{ Ciclo de Vida da VLP } \\
\hline & & $\begin{array}{l}\text { Produção } \\
\text { Florestal (1) }\end{array}$ & $\begin{array}{l}\text { Beneficia- } \\
\text { mento (2) }\end{array}$ & $\begin{array}{c}\text { Construção } \\
\text { (3) }\end{array}$ & $\begin{array}{l}\text { Uso e manu } \\
\text { tencão (4) }\end{array}$ & $\begin{array}{l}\text { Descons- } \\
\text { trucão (5) }\end{array}$ \\
\hline \multicolumn{7}{|c|}{ Ambiental } \\
\hline \multirow{3}{*}{ 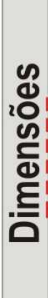 } & Social & & & & & \\
\hline & Econômica & $\begin{array}{c}\text { Análise } \\
\text { E - } 1\end{array}$ & $\begin{array}{c}\text { Análise } \\
\text { E - } 2\end{array}$ & $\begin{array}{c}\text { Análise } \\
\text { E - } 3\end{array}$ & & \\
\hline & Cultural & & & & & \\
\hline & Política & & & & & \\
\hline
\end{tabular}

Figura 44: Matriz de análise dos dados com apresentação das relações da dimensão econômica. Fonte: Autor.

\section{Análise E - 1}

\section{A questão econômica no processo de produção florestal e suas relações com os outros processos do ciclo de vida.}

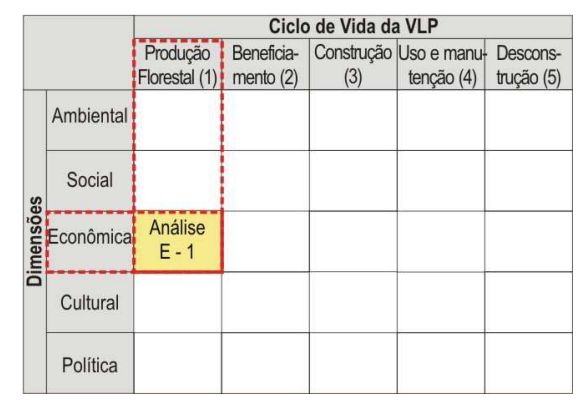

A produtividade no processo de produção florestal está ligada aos ciclos de plantio das árvores (tempo de crescimento das mudas) e a área demandada para tal plantio, sendo necessário um estudo para se prever um abastecimento contínuo de toras suficiente para atender a demanda do mercado. O setor de produção florestal no Brasil tem uma das maiores capacidades produtivas do mundo e um grande potencial para atender a demanda de madeira serrada para a construção civil, apresentando em 2006 uma área de 1.824.269 ha de plantios de Pinus, com a previsão de um plantio de 800.000 novos ha para o ano de 2008, SOCIEDADE BRASILEIRA DE SILVICULTURA (2007). Para se analisar a qualidade desses plantios pode-se partir dos dados do mesmo autor sobre as certificações da ISO 14001 ou FSC para esse tipo de cultivo, que já chegam a 91.213 ha ou 5\% das florestas plantadas no Brasil, segundo dados de 2006.

A capacidade de fornecimento de toras ao longo de um período á diretamente influenciada pelo tempo de ciclos de plantios, e, para que seja constante, devem haver áreas com diferentes datas de plantio. $\mathrm{Na}$ empresa $\mathrm{A}$, onde foram levantados os dados da produção florestal, essa prática é adotada, mas contatou-se que o fornecedor de toras para a serraria Brancalhão encerrou suas 
atividades em 2004 após o corte do último talhão, demonstrando a necessidade de se haver um planejamento e um manejo corretos no processo de produção florestal para a utilização sustentável e a longo prazo da madeira como matéria prima para a construção civil.

No indicador Investimento, a empresa investe $42 \%$ de sua receita líquida em pagamentos e benefícios de funcionários, obtendo conseqüentemente um dos melhores índices de toda a cadeia no indicador Público Interno. Além disso, oferece auxílios à comunidade, na educação e no desenvolvimento de projetos para o meio ambiente, que apesar de não apresentarem uma porcentagem grande (cerca de $1,5 \%$ da receita líquida), trouxeram um bom desempenho da empresa nos indicadores relacionados a esses temas.

Ainda em Investimento, chama a atenção o custo operacional atual da empresa, que atinge R\$ 123.182.000,00 por mês, mas deve-se considerar que, para a sua implantação, houve um grande investimento de capital acumulado por investidores privados, nesse caso uma multinacional estrangeira, o que inviabilizaria a reprodução desse modelo para a maioria absoluta da população brasileira.

No indicador de distribuição de riquezas a empresa apresentou os melhores índices em porcentagem, destinando $42 \%, 11 \%$ e $0,22 \%$ de sua receita líquida para o público interno, governo e comunidade respectivamente, porém essa distribuição ainda deveria ser analisada pelo número de beneficiados em cada porcentagem, pois os acionistas da empresa, apesar de percentualmente receberem menos que os funcionários, têm uma remuneração muito maior, ressaltando o grande desequilíbrio na distribuição das riquezas, questionada por Sachs (1993) na discussão da dimensão econômica da sustentabilidade. A comparação desse indicador com o processo de construção será feita durante a análise desse processo por apresentar muitas especificidades.

Assim, de forma geral, ainda que os padrões colocados pela empresa não possibilitem a reaplicação da experiência para a população de baixa renda, como seria desejável considerando-se as diretrizes gerais de sustentabilidade, a empresa apresentou bons desempenhos dentro dos indicadores propostos para a dimensão econômica. 
Análise E - 2

A questão econômica no processo de

beneficiamento da madeira e suas relações com os outros processos do ciclo de vida.

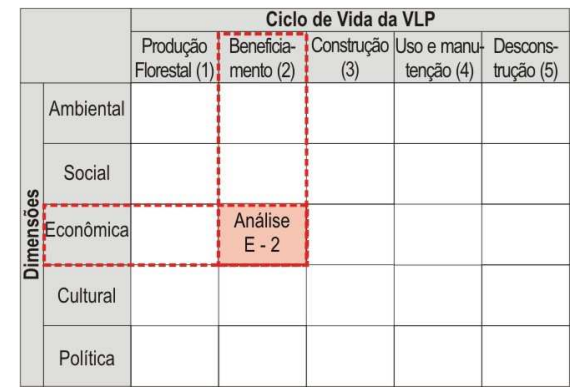

A empresa Brancalhão possui duas serrarias em sua sede, uma delas sem funcionamento por falta de demanda e a outra com produtividade de $2000 \mathrm{~m}^{3}$ de madeira serrada de Pinus por mês, sendo $200 \mathrm{~m}^{3}$ referentes à madeira de $3^{\mathrm{a}}$ qualidade, quantidade suficiente para fornecer matéria prima para o sistema estrutural de cobertura em VLP para 53 habitações/mês. O setor de madeira serrada no Brasil é formado em grande parte por empresas de pequeno porte $(76,4 \%)$ com produção voltada para o comércio local, cenário que aponta uma capacidade produtiva para fornecimento de madeira para o setor de construção civil, e que no entanto necessita de melhores relações entre os fornecedores de toras, as serrarias e a demanda do mercado, para que haja um abastecimento contínuo de toras e para que a madeira serrada tenha seu uso mais difundido no mercado da construção civil, pois segundo a SOCIEDADE BRASILEIRA DE SILVICULTURA (2007), dos $9.078 .000 \mathrm{~m}^{3}$ de madeira serrada de Pinus produzidos no Brasil em 2006, $1.331 .000 \mathrm{~m}^{3}$ foram destinando somente para a exportação

A empresa apresentou o menor desempenho em relação a investimentos, não havendo nenhuma ação em relação à produtividade (justificado pela falta de demanda) ou melhorias do produto, quadro que se repete no indicador de distribuição de riquezas, onde o público interno, governo e comunidade recebem porcentagens, em relação à receita líquida da empresa, inferiores às da empresa de produção florestal.

Assim pode-se considerar uma baixa sustentabilidade econômica dessa empresa pelo não atendimento das diretrizes da dimensão econômica colocadas por Silva, S. (2000) e Yuba (2005), em relação à "realização do potencial econômico que contemple prioritariamente a distribuição de riqueza e renda associada a uma redução das externalidades socioambientais, buscando-se resultados macrossociais positivos". 
Análise E - 3

\section{A questão econômica no processo de construção e suas relações com os outros processos do ciclo de vida.}

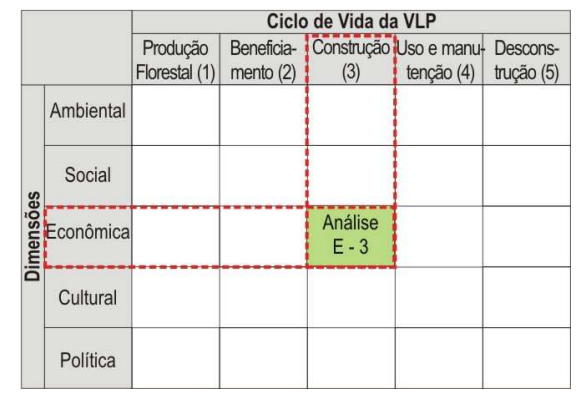

A produtividade no processo de construção foi, em média, de um sistema estrutural préfabricado e montado em 5,7 dias, ou $0,66 \mathrm{~m}^{3}$ de sistema estrutural pré-fabricado e montado por dia, sendo que na operação de pré-fabricação a matéria prima seguia uma linha de produção contínua, enquanto que na operação de montagem vários componentes eram instalados em habitações diferentes ao mesmo tempo, aumentando a produtividade dessa operação em relação à primeira. A sub-operação de pregação do sistema, feita manualmente, foi responsável por 21\% do tempo total gasto, e, apesar de ter atendido a produtividade proposta pela equipe técnica para o bom andamento da obra, ainda pode ter alguns avanços, como por exemplo, a adoção de pregadores pneumáticos, para melhorar a produtividade do sistema.

Com relação aos investimentos, pode-se considerar as capacitações e a própria implantação da marcenaria, visto que antes do projeto não havia nenhuma capacidade produtiva instalada para esse fim. Para as capacitações, treinamentos e busca de materiais mais sustentáveis foram destinados em média 11\% do valor (de materiais) do sistema estrutural para assessoria técnica, representando o maior investimento para o público interno dentro do ciclo de vida. Para a sua implantação (compra das máquinas e seção de uso do local) foram necessários $\mathrm{R} \$ 12.000,00$, representando $29,9 \%$ do valor total do sistema para 36 habitações, considerando-se um gasto de $\mathrm{R} \$ 333,00$ por sistema estrutural. A necessidade de baixos investimentos viabilizou a implantação da marcenaria coletiva com verbas destinadas a populações carentes, sendo possível atender as demandas locais e gerar trabalho e renda, trazendo assim um grande retorno em qualidade de vida para uma população local, usualmente não contemplada por iniciativas de empresas privadas do mercado.

Durante o processo de produção dos componentes para o sistema estrutural de cobertura a marcenaria não gerou nenhum tipo de renda (sistema de mutirão e troca de serviços), portanto a divisão da receita líquida da empresa pelos atores sociais, proposta pelo indicador de distribuição de riquezas, não poderá ser avaliada nessa operação. Os gastos com assessoria e manutenção da marcenaria foram pagos pelos recursos federais e estaduais destinados a projetos sociais, invertendo a lógica de que a empresa deveria investir nessas áreas, sendo ela o foco dos 
investimentos. Destaca-se aqui que todos os recursos do projeto foram investidos nos interesses dos assentados e que todo o trabalho feito pelos mutirantes foi convertido em benefícios próprios (construção do sistema estrutural de cobertura e criação da marcenaria coletiva), portanto, o fato dos trabalhadores não receberem nenhuma remuneração pelo trabalho feito no mutirão, o que aparentemente reflete em uma porcentagem de $0 \%$ na distribuição "formal" de riquezas, traz, em contrapartida, benefícios que as famílias não conseguiriam adquirir por outros programas habitacionais ou outras formas de acumulação de capital. Segundo Max apud Chauí (1982), o lucro ou capital "é o trabalho não pago", ou seja, é a apropriação, por parte dos detentores dos meios produtivos, do trabalho de uma massa assalariada, que só possui a sua força de trabalho como forma de troca, e que muitas vezes não consegue ter acesso aos bens a que produz devido a essa depreciação do valor de seu trabalho. Assim, pode-se dizer que os mutirante transformaram $100 \%$ de seu trabalho em bens para seu próprio consumo, o que não acontece na distribuição de riquezas de uma empresa convencional, onde somente parte de seu trabalho retornará para seu benefício.

Dessa forma o empreendimento desse processo atinge uma alta sustentabilidade econômica por atender as diretrizes macroeconômicas colocadas pelos autores durante a revisão bibliográfica e os indicadores já analisados nos outros processos, resultando em uma experiência capaz de melhorar a sustentabilidade, na maioria dos seus indicadores, em como o processo de construção é feito atualmente.

\subsection{Análise da dimensão cultural ao longo do ciclo de vida do sistema estrutural em VLP.}

A análise da dimensão cultural será feita a partir dos levantamentos qualitativos, não havendo nenhum levantamento quantitativo ou mesmo ponderação sobre os indicadores propostos. Assim a análise se baseará nos indicadores propostos durante a seleção de categorias de impacto, e utilizará a matriz de análise dos dados para visualização das relações de ganhos e perdas de sustentabilidade. 


\begin{tabular}{|c|c|c|c|c|c|c|}
\hline & \multicolumn{5}{|c|}{ Ciclo de Vida da VLP } \\
\hline & & $\begin{array}{l}\text { Produção } \\
\text { Florestal (1) }\end{array}$ & $\begin{array}{l}\text { Beneficia- } \\
\text { mento (2) }\end{array}$ & $\begin{array}{c}\text { Construção } \\
\text { (3) }\end{array}$ & $\begin{array}{l}\text { Uso e manu- } \\
\text { tenção (4) }\end{array}$ & $\begin{array}{l}\text { Descons- } \\
\text { trução (5) }\end{array}$ \\
\hline \multicolumn{2}{|r|}{ Ambiental } & & & & & \\
\hline \multirow{4}{*}{ 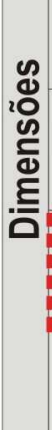 } & Social & & & & & \\
\hline & Econômica & & & & & \\
\hline & Cultural & $\begin{array}{c}\text { Análise } \\
\text { C-1 }\end{array}$ & $\begin{array}{c}\text { Análise } \\
\text { C - } 2\end{array}$ & $\begin{array}{c}\text { Análise } \\
\text { C - } 3\end{array}$ & $\begin{array}{c}\text { Análise } \\
\text { C - } 4\end{array}$ & $\begin{array}{c}\text { Análise } \\
\text { C - } 5\end{array}$ \\
\hline & Política & & & & & \\
\hline
\end{tabular}

Figura 45: Matriz de análise dos dados com apresentação das relações da dimensão econômica.

Fonte: Autor.

\section{Análise C - 1}

\section{A questão cultural no processo de produção \\ florestal e suas relações com os outros processos do ciclo de vida.}

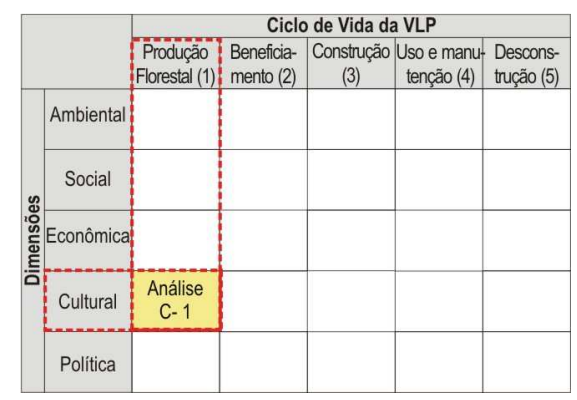

A empresa trabalha com um ramo (plantio de madeira de Pinus) consolidado no mercado e já legalizado pelo governo e por órgãos certificadores, apesar de ser relativamente recente no país (menos de 50 anos), e adota uma postura conservadora quanto à forma de produção, mantendo o padrão de mercado e buscando somente algumas inovações para a melhoria do seu produto em relação a impactos ambientais, sem no entanto apresentar grandes avanços nos indicadores de reavaliação do tradicional e superação da resistência aos materiais mais sustentáveis. A internalização da sustentabilidade dentro da empresa foi o melhor indicador cultural do ciclo de vida, e apresentou práticas formais como cursos e palestras de educação ambiental.

No geral o processo tem uma média sustentabilidade cultural considerando-se as diretrizes colocadas na revisão da literatura, pois apesar de não interferir na "garantia de preservação de patrimônios históricos, urbanísticos, respeitando a diversidade das culturas dos povos em suas formas expressão e representação" tem grande influência na "interferência paisagística e ambiental do espaço" em que está inserida. 
Análise C - 2

A questão cultural no processo de beneficiamento da madeira e suas relações com os outros processos do ciclo de vida.

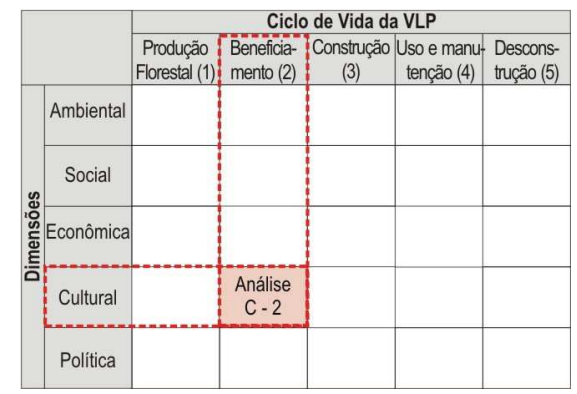

A empresa não apresentou nenhuma prática relevante relacionada aos indicadores propostos, adotando materiais e processos usuais de mercado, tais como a utilização convencional da madeira de reflorestamento para caixaria e embalagens, sem procurar inovações em relação a formas de produção (como o mutirão) ou práticas sustentáveis. Assim, tem-se o embate entre as diretrizes de proposição de novas formas de atuação na sociedade com propostas mais sustentáveis, colocadas como metas por Yuba (2005, p. 30), e de manutenção da cultura vigente, proposta por Silva, S. (2000) em seu quadro de diretrizes da sustentabilidade. No objeto de estudo está colocado claramente o respeito à forma tradicional de produção e de utilização de um produto, que, mesmo não tendo gerado relações de ganho de sustentabilidade com outras dimensões (ver análise entre dimensões), é colocado como fator essencial para que se atinja uma maior sustentabilidade por todos os autores citados no capítulo de revisão da literatura, como Leroy et al, que afirma que são essas formas de produção atuais que geram os impactos em todas as outras dimensões. No entanto, partindo-se dos indicadores propostos por Yuba (2005) de mudança na atuação da sociedade atualmente, e avaliando-se também a possibilidade de perda de patrimônios históricos, urbanísticos, paisagísticos e ambientais, levantada por Silva, S. (2000), pode-se dizer que esse processo possui uma baixa sustentabilidade já que não propõe novas formas de organização, apesar de não interferir nos patrimônios da sociedade local.

Análise C - 3 , C - 4 e C - 5 .

A questão cultural no processo de construção, operação de uso e manutenção e operação de desconstrução e suas relações com os outros processos do ciclo de vida.

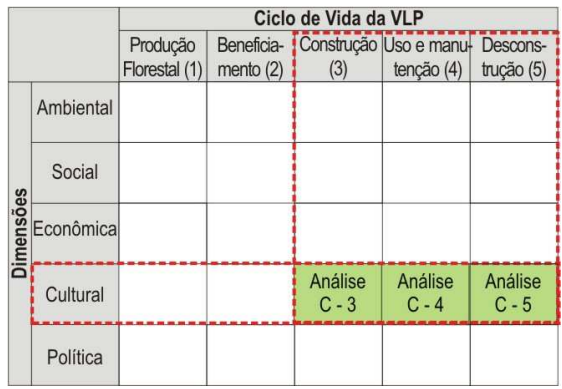

O indicador cultural de melhor desempenho no processo de construção foi a reavaliação do tradicional, com discussões e revisões das formas de utilização de materiais e dos seus processos 
de construção. Durante o processo de projeto e escolha dos sistemas construtivos a equipe de pesquisadores apresentou às famílias protótipos, orçamentos e ensaios estruturais dos sistemas propostos, esclarecendo as vantagens e desvantagens de cada um para que pudessem fazer uma escolha consciente. O resultado desse processo participativo foi a escolha do sistema estrutural de cobertura em VLP utilizando-se madeira de Pinus de $3^{\text {a }}$ qualidade, (antes sub-utilizada e então valorizada por um novo desenho estrutural e pelo sistema de mutirão como processo de produção) para 36 das 42 habitações, representando a superação da resistência aos materiais e técnicas mais sustentáveis por $87 \%$ das famílias.

O indicador com menor desempenho nesse processo foi a internalização da sustentabilidade, pois, apesar do avanço na aceitação de um sistema não convencional, as decisões tomadas partiram de variáveis econômicas, sendo que os temas ambientais e sociais não foram citados como fatores de escolha do sistema construtivo nas entrevistas realizadas.

Partindo do mesmo debate da discussão anterior pode-se verificar que nesse processo há uma mudança significativa nas formas de produção e de utilização de materiais convencionais, sempre respeitando as decisões das famílias, que também fizeram escolhas de sistemas tradicionais, como no caso do telhado de duas águas utilizando-se telha cerâmica. Assim pode-se considerar que essa questão teve um bom desempenho pelos indicadores propostos por Yuba (2005) e por Silva, S. (2000), resultando no processo de maior sustentabilidade cultural do ciclo de vida estudado.

\subsection{Análise da dimensão política ao longo do ciclo de vida do sistema estrutural em VLP.}

A análise da dimensão política será feita de forma qualitativa, por não apresentar dados quantitativos ou indicadores ponderados, e será baseada nos indicadores propostos durante o item de seleção de categorias de impacto. Também será utilizada a matriz de análise dos dados para visualização das relações de ganhos e perdas de sustentabilidade. 


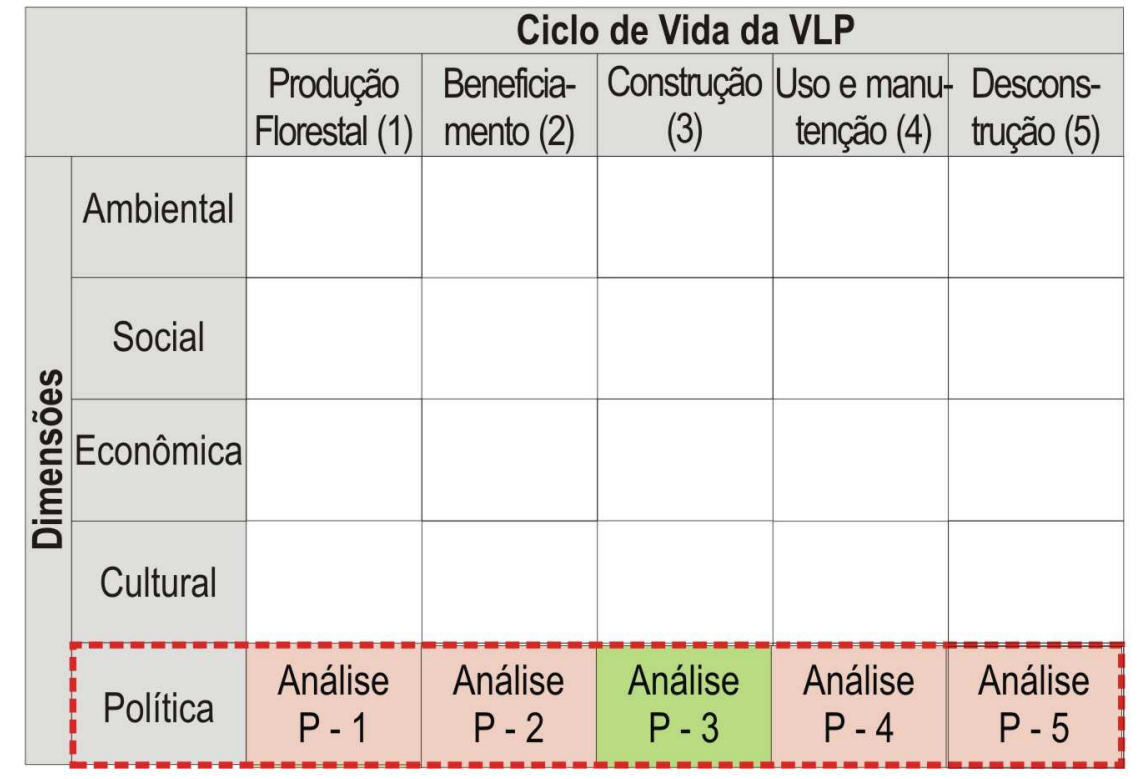

Figura 46: Matriz de análise dos dados com apresentação das relações da dimensão econômica.

Fonte: Autor.

\section{Análise P - 1}

\section{A questão política no processo de produção florestal} e suas relações com os outros processos do ciclo de vida.

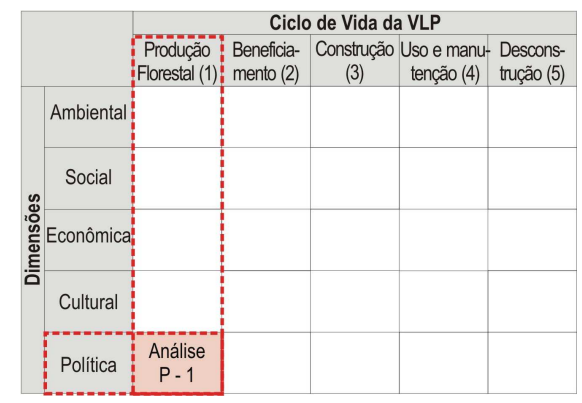

As melhores práticas da empresa A nesse tema estão relacionadas aos indicadores de Valores Organizacionais, Cooperação para o Desenvolvimento de Construções mais Sustentáveis e Monitoramento e Avaliação da Própria Empresa, com pesquisas na área de processos mais sustentáveis, elaboração periódica de relatórios de responsabilidade social, certificações auditadas por terceiros e canal de comunicação permanente com sindicatos. No indicador de Organização das Partes Interessadas a empresa apresenta poucos avanços, concentrando as decisões de planejamento estratégico e de diretrizes de atuação da empresa exclusivamente nos acionistas e membros da direção da empresa. Assim, o empreendimento aproxima-se do que Sachs (1003) chama de "uma solução imposta de cima para baixo", citando casos onde essa solução não trouxe resultados positivos em contraposição a ações iniciadas por pequenas comunidades, garantindo à empresa uma baixa sustentabilidade política. 
Análise $\mathbf{P}-2$

A questão política no processo de beneficiamento da madeira e suas relações com os outros processos do ciclo de vida.

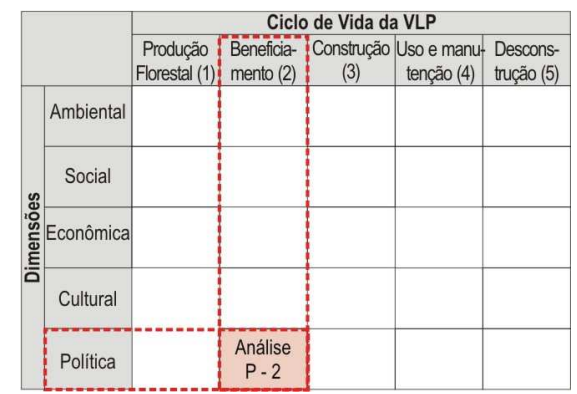

A ação de desenvolvimento de parcerias com outras serrarias, para compra de seus resíduos, e com indústrias, para venda dos resíduos coletados, faz com que a empresa crie uma rede de relações dentro do setor de serrarias da região. Além disso, a empresa apóia a filiação de seus funcionários aos sindicatos, ainda que apenas como simples cumprimento da legislação.

Entretanto, em todos os outros indicadores, o processo de beneficiamento da madeira não apresentou nenhuma ação ou projeto dentro das áreas propostas que contribuísse ativamente para as mudanças culturais de forma de produção e de inovações nos produtos da empresa, mantendo apenas o posicionamento padrão de respeitar as leis vigentes. Assim obteve o menor desempenho em todos os indicadores desse tema em relação aos processos do ciclo de vida estudado, podendo-se fazer a mesma avaliação do processos anterior, onde uma baixa participação dos agentes envolvidos nas decisões estratégicas resultam em uma baixa sustentabilidade política.

Análise P - 3, P - 4 e P - 5 .

A questão política no processo de construção, operação de uso e manutenção e operação de desconstrução e suas relações com os outros processos do ciclo de vida.

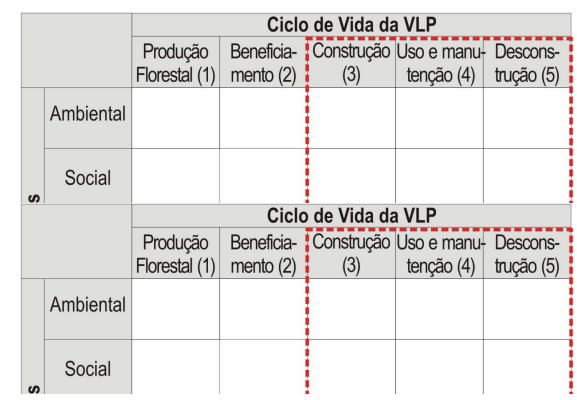

O melhor desempenho de todo o ciclo de vida no indicador Organização das Partes Interessadas foi no processo de construção, onde as famílias foram organizadas em grupos que tomavam decisões em reuniões e assembléias gerais com a participação de todos os envolvidos. Outro ponto positivo nesse processo foram as parcerias com as universidades para o desenvolvimento de técnicas e processos construtivos mais sustentáveis. Os indicadores com pior desempenho foram os relacionados ao monitoramento de suas ações, que apesar de serem fiscalizados pelas entidades financiadoras através de relatórios, não eram auditadas. A associação aos sindicatos também teve um baixo desempenho, pois nesse caso os trabalhadores não são reconhecidos 
oficialmente, além de muitas vezes mostrarem o desconhecimento da existência dessas organizações.

As operações de manutenção e desconstrução não foram inseridas dentro do projeto InovaRural e a organização e monitoramento para a execução dessas operações ficaram sob responsabilidade das próprias famílias e não da assessoria técnica que coordenou o processo de construção. Nesse caso tem-se uma baixa sustentabilidade política, pois não há nenhuma iniciativa ou proposta para formulação de mecanismo visando o aumento da participação das famílias nessas operações, mantendo-se o sistema tradicional de responsabilidades e hierarquias dos órgãos envolvidos.

Embora o processo apresente alguns pontos negativos, de forma geral ainda pode ser citado como um bom exemplo de atendimento à diretriz proposta "criação de mecanismos que incrementem a participação da sociedade nas tomadas de decisões, reconhecendo e respeitando os direitos de todos, superando as práticas e políticas de exclusão e permitindo o desenvolvimento da cidadania ativa", e é através desse processo de divisão de poder, colocado por Sachs (1993) como um dos principais caminhos para a sustentabilidade, que o empreendimento visa perpassar todas as dimensões da sustentabilidade, resultando em um bom desempenho na dimensão política.

\subsection{Análise das relações entre as dimensões do processo de produção florestal.}

Nessa segunda fase de análise os dados levantados de cada categoria serão relacionados com as diferentes dimensões, e se basearão nas relações dos resultados das análises por dimensões isoladas, feitas no item acima, identificando-se se o ganho ou perda de sustentabilidade naquele caso está relacionado ou repercute nos ganhos e perdas de sustentabilidade de outras dimensões, além de identificações a partir dos cruzamentos dos resultados de todos os processos e dimensões. As relações poderão ser de ganhos ou perdas mútuas de sustentabilidade, onde a ação dentro de uma dimensão interfere da mesma maneira (positivamente ou negativamente) em outras dimensões, ou de ganhos e perdas inversas entre dimensões, quando há o aumento de sustentabilidade em uma dimensão e a diminuição na outra.

Essa etapa será iniciada com a análise das relações entre as cinco dimensões no processo de produção florestal, e também será utilizada a matriz de análise dos dados seguindo-se o mesmo 
procedimento usado na primeira parte do capítulo, porém agora as análises serão nomeadas de acordo com os processos e não mais pelas dimensões.

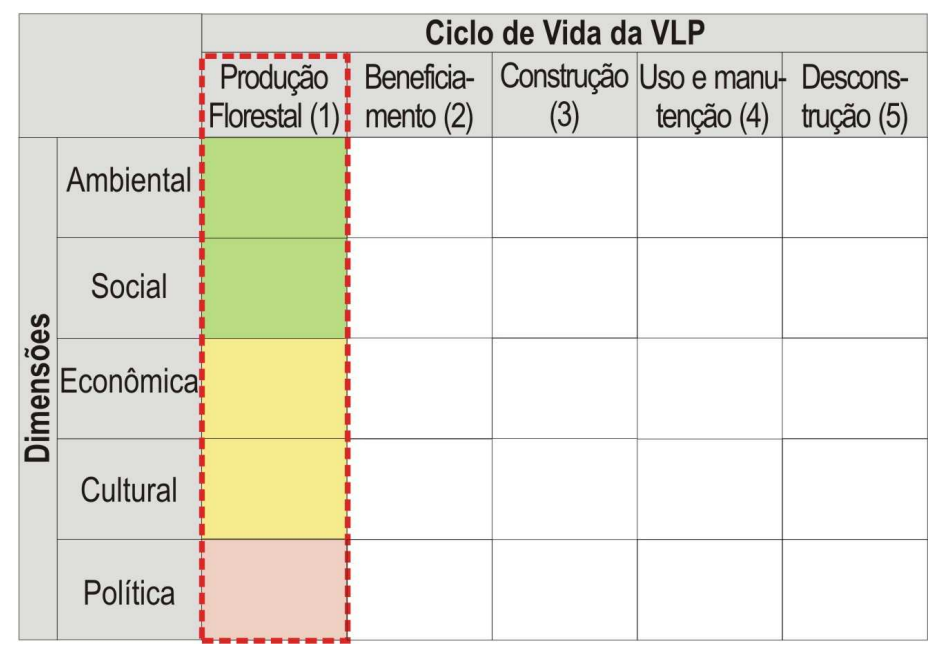

Figura 47: matriz de análise dos dados com apresentação das relações entre dimensões no processo de produção florestal.

Fonte: Autor.

A primeira relação que pode ser estabelecida nesse processo é entre o ganho na sustentabilidade ambiental e social e a perda no indicador de investimentos na dimensão econômica. Todos os investimentos nos projetos de pesquisa ambiental e certificações, e nos de melhoria de qualidade de vida do público interno e comunidade, estão vinculados a um alto investimento financeiro por parte da empresa, avaliado anteriormente com baixa capacidade de ser reproduzido no contexto do Brasil. Porém, destaca-se que esses investimentos não estão diretamente ligados ao desempenho quantitativo nas categorias ambientais (sendo que os mesmos padrões de emissões e matéria prima poderiam ser atingidos por processos florestais sem tais investimentos) e sim qualitativos (como no caso das pesquisas para manutenção da flora e fauna nativas, entre outras). Nesse processo também houve ganho mútuo de sustentabilidade nos indicadores de distribuição de riquezas da dimensão econômica, com $42 \%$ da renda líquida destinada aos funcionários, e público interno da dimensão social, que atingiu uma alta ponderação.

O baixo desempenho da dimensão política devido à não participação dos funcionários e comunidade no planejamento da empresa também está relacionado com o baixo desempenho social no tema Comunidade e com alguns indicadores do tema Público Interno.

Existe um ganho mútuo nas dimensões social, ambiental e cultural, devido ao alto grau de internalização dos conceitos de sustentabilidade por parte da empresa, que coloca as questões socioambientais como uma de suas diretrizes. 


\subsection{Análise das relações entre as dimensões do processo de beneficiamento da madeira.}

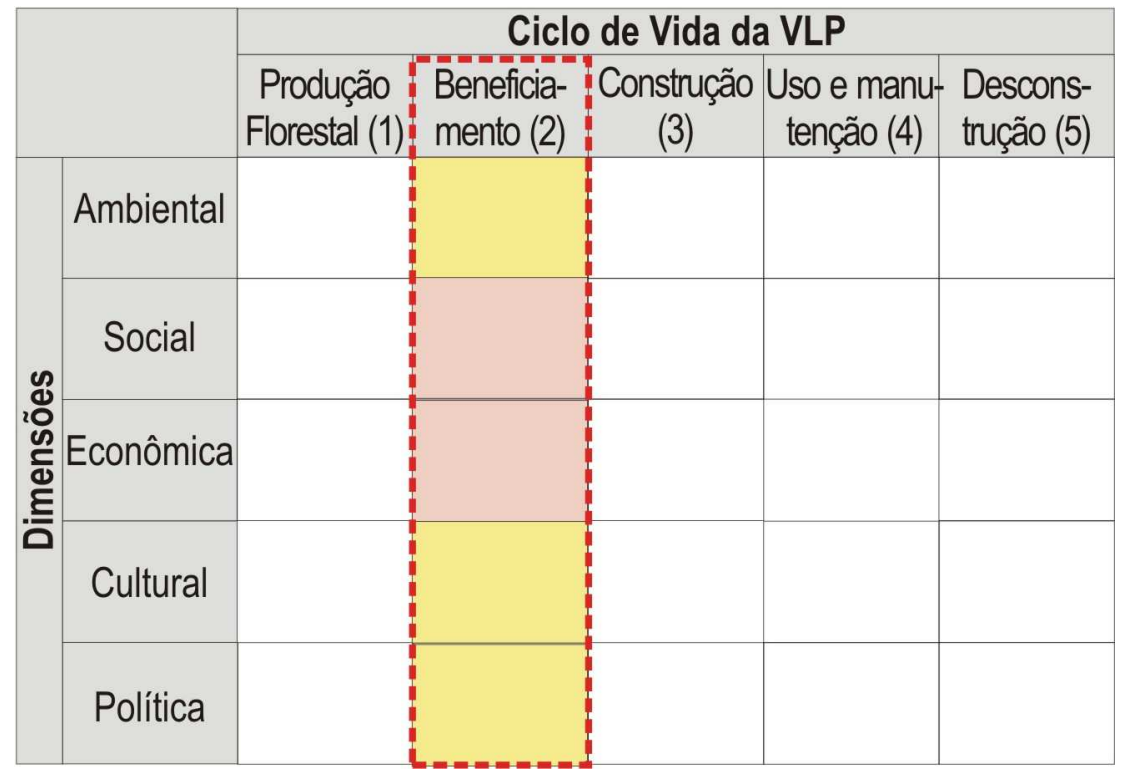

Figura 48: Matriz de análise dos dados com apresentação das relações entre dimensões no processo de beneficiamento da madeira.

Fonte: Autor.

Dentro desse processo destaca-se o ganho mútuo de sustentabilidade na dimensão ambiental e no indicador de Organização para o Desenvolvimento Sustentável e Organização das Partes Interessadas da dimensão política, onde, através de articulações entre empresas ligadas à cadeia produtiva da madeira, a empresa passou a transformar os cavacos, pó-de-serra e madeira de terceira qualidade, que antes eram resíduos, em matérias primas para geração de energia, uso em granjas e matéria prima para construção civil, respectivamente.

O baixo desempenho cultural no indicador de internalização da sustentabilidade é apontado como a causa da ausência de propostas e ações para melhoria da sustentabilidade, em todas as dimensões, de seus produtos e forma de produção, mas em contrapartida o empreendimento não interfere nos patrimônios históricos, urbanísticos, paisagísticos ou ambientais, diretrizes culturais levantadas por Silva, S. (2000), garantindo-lhe um melhor desempenho cultural nesse aspecto. 


\subsection{Análise das relações entre as dimensões do processo de construção.}

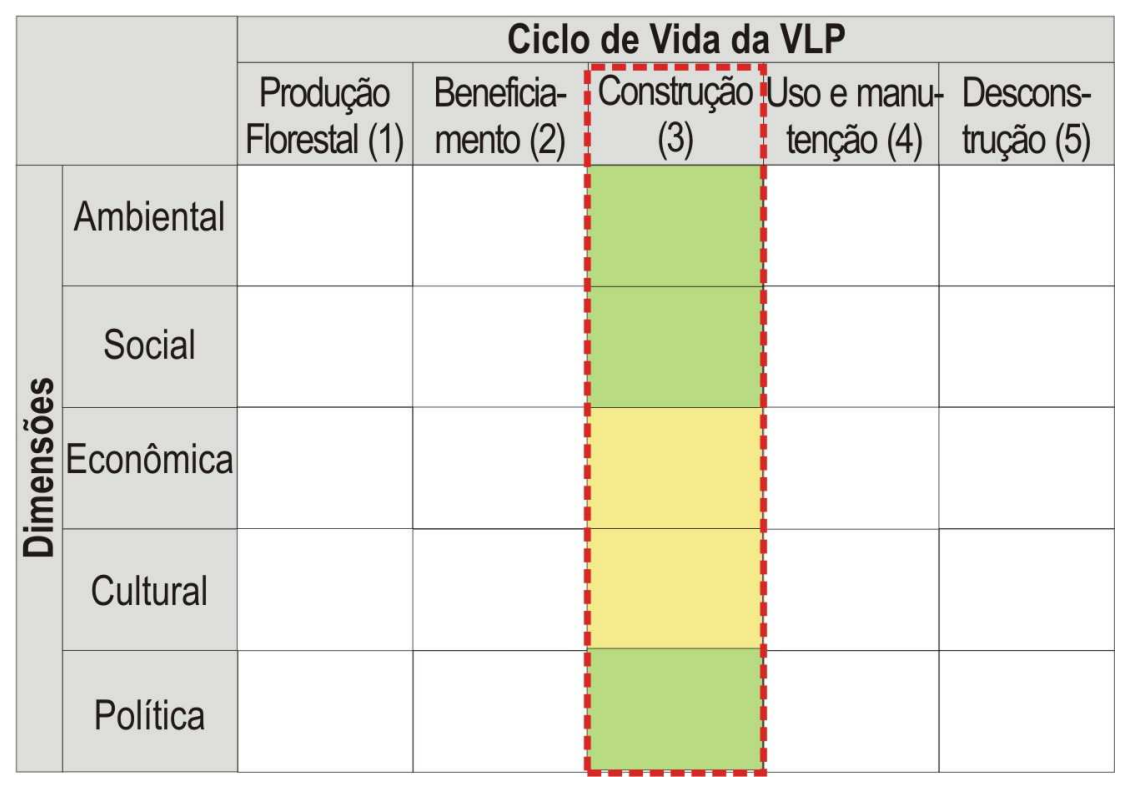

Figura 49: Matriz de análise dos dados com apresentação das relações entre dimensões no processo de beneficiamento da madeira.

Fonte: Autor.

Nesse processo existe um ganho mútuo de sustentabilidade devido à relação entre a dimensão política, no indicador de Organização das Partes Interessadas para Conquista da Participação Ativa nas Decisões, e as dimensões social, econômica e cultural. Esse ganho se deu com a intervenção e decisão das famílias na estruturação do empreendimento da marcenaria coletiva e do mutirão, favorecendo os índices nos indicadores de Investimentos, Crescimento Profissional, Relações com a comunidade, entre outros. Esses procedimentos estão intrinsecamente ligados à melhoria da sustentabilidade e uma nova forma de interação entre a sociedade e desta com o meio ambiente proposta por Sachs (1993), Santos, M. (1994) e CIB E UNEP-IETC, 2002), através da relações de distribuição de poder entre os diferentes atores sociais, com as outras questões, ambientais, sociais e econômicas.

Nesse processo existe uma relação entre a dimensão econômica e cultural onde a baixa condição de investimentos das famílias para pagamento de mão-de-obra e materiais construtivos de alto custo teve como conseqüência o resgate do processo de construção em regime de mutirão e a aceitação de sistemas construtivos não convencionais, mesmo não havendo uma grande internalização da sustentabilidade ambiental por parte das famílias. O predomínio da questão econômica mostra que futuras escolhas poderão continuar sendo determinadas simplesmente por esse fator, não contribuindo com mudanças culturais capazes de absorver novas tecnologias e processos mais sustentáveis. 
Também houve ganho mútuo de sustentabilidade na relação entre as dimensões econômica e social e ambiental, onde todos os investimentos feitos no projeto foram convertidos em benefícios para as famílias, para a comunidade e para a pesquisa de produtos e processos mais sustentáveis. Essa foi a melhor prática dentro do ciclo de vida para a melhoria da qualidade de vida dos envolvidos, com geração de trabalho e renda, possibilidade de capacitação de jovens e atendimento das demandas da comunidade, ganhos que se enquadram dentro das diretrizes de sustentabilidade social e econômica já colocadas anteriormente.

\subsection{Análise das relações entre as dimensões da operação de manutenção.}

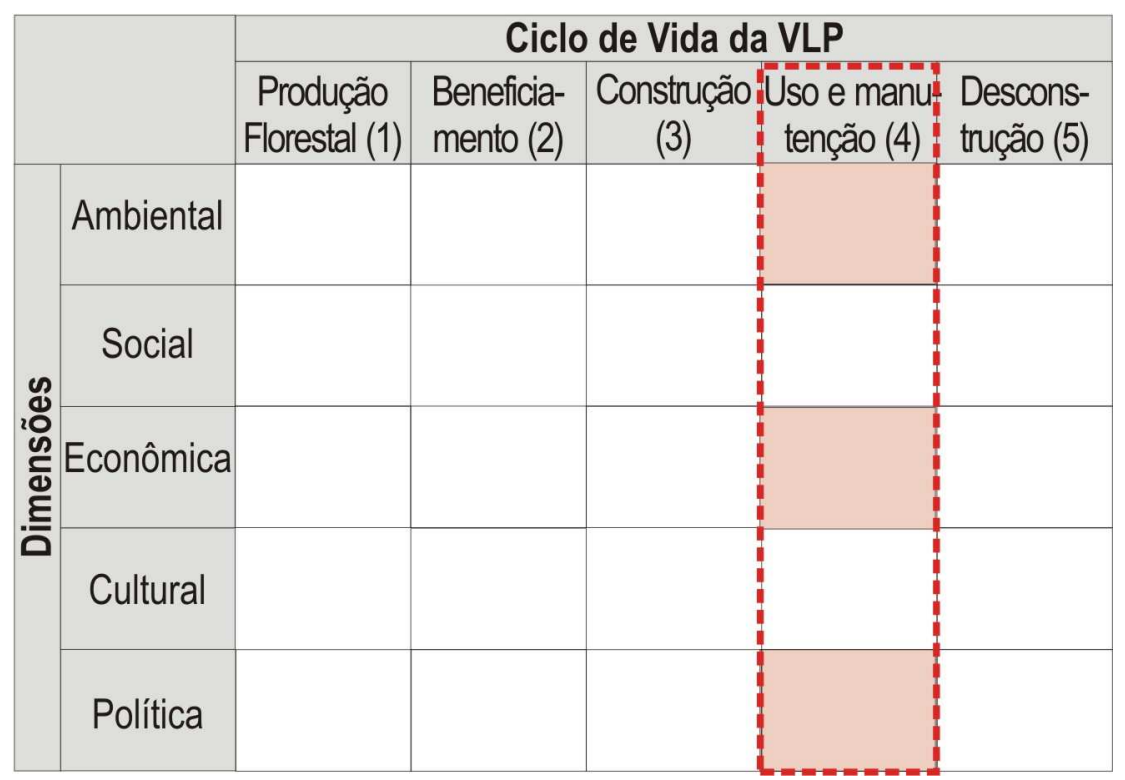

Figura 50: Matriz de análise dos dados com apresentação das relações entre dimensões no processo de beneficiamento da madeira. Fonte: Autor.

$\mathrm{Na}$ operação de manutenção existe uma perda mútua de sustentabilidade ligada às dimensões ambiental, econômica e política. O fato do investimento para o sistema estrutural não ter contemplado a etapa de manutenção (todo o recurso foi utilizado durante a construção do sistema) e de não haver uma organização do setor da construção civil para o monitoramento dessa operação (com apoio técnico ou de qualquer origem), existe uma grande possibilidade do tratamento preservativo não ser reaplicado a cada cinco anos, possibilitando o ataque de insetos xilófagos e o comprometimento da estrutura, que nesse caso necessitaria de mais matéria prima para reposição de componentes ou mesmo para troca do sistema estrutural. 


\subsection{Análise das relações entre as dimensões da operação de desconstrução e disposição final.}

\begin{tabular}{|c|c|c|c|c|c|c|}
\hline & \multicolumn{5}{|c|}{ Ciclo de Vida da VLP } \\
\hline & & $\begin{array}{l}\text { Produção } \\
\text { Florestal (1) }\end{array}$ & $\begin{array}{l}\text { Beneficia- } \\
\text { mento (2) }\end{array}$ & $\begin{array}{l}\text { Construção } \\
\text { (3) }\end{array}$ & $\begin{array}{l}\text { Uso e manu } \\
\text { tenção (4) }\end{array}$ & $\begin{array}{l}\text { Descons- } \\
\text { trução (5) }\end{array}$ \\
\hline \multicolumn{7}{|c|}{ Ambiental } \\
\hline \multicolumn{7}{|c|}{ ¿ Social } \\
\hline \multicolumn{7}{|c|}{ ¿0. Econômica } \\
\hline \multicolumn{7}{|c|}{ Cultural } \\
\hline & Política & & & & & \\
\hline
\end{tabular}

Figura 51: Matriz de análise dos dados com apresentação das relações entre dimensões no processo de beneficiamento da madeira.

Fonte: Autor.

Nessa operação existe uma perda mútua de sustentabilidade entre as dimensões ambiental, cultural, econômica, política. Considerando-se a análise de falta de internalização da sustentabilidade, relacionada com a falta de recursos financeiros das famílias para a disposição final do sistema estrutural e a falta de articulação entre os agentes dessa cadeia para monitorar esses processos, pode-se considerar a possibilidade da deposição dos componentes contaminados com cipermetrina em solo aberto, e não em aterro industrial. Caso esse cenário aconteça, os impactos de emissões de substâncias tóxicas para o solo e água serão alterados, devendo haver um novo estudo sobre eles.

\section{Análise síntese}

A partir das análises apresentadas poder-se-á fazer uma síntese dos pontos de maior e menor sustentabilidade ao longo do ciclo de vida e as relações entre as dimensões estudadas, acrescentando algumas considerações gerais sobre essa fase de análise dos dados com auxílio da apresentação da matriz de análise dos resultados com todas as relações levantadas anteriormente em uma mesma matriz, ver figura 52. 


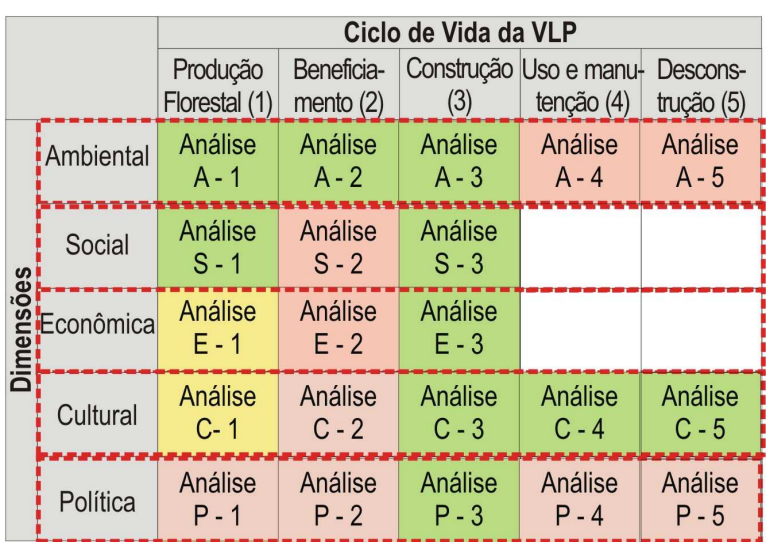

(a)

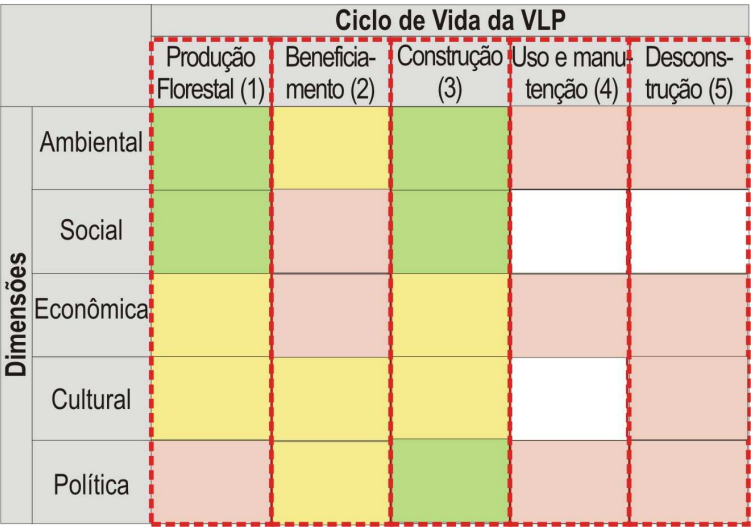

(b)

Figura 52: Matriz síntese de análise da sustentabilidade na análise das dimensões ao longo dos processos (a) e entre as diferentes dimensões em um processo (b).

Fonte: Autor.

Através da matriz síntese de análise da sustentabilidade é possível identificar visualmente e de forma simplificada os pontos de maior e menor sustentabilidade ao longo do ciclo de vida, porém essa não indica quais processos se relacionam entre si para que haja esse ganho ou perda de sustentabilidade, o que só pode ser identificado nas matrizes de análise da cada processo ou dimensão durante esse capítulo, onde de forma geral foi possível constatar o grande número de relações entre diferentes dimensões em um mesmo processo. Essas relações foram menos evidentes durante as análises entre diferentes processos em uma mesma dimensão, encontrandose relações de ganhos e perdas da sustentabilidade somente na dimensão ambiental, enquanto nas outras os indicadores adotados refletiram impactos dentro de cada dimensão isoladamente. Essa falta de relações quanto às dimensões social, econômica, política e cultural é decorrente da falta de relações entre as organizações ao longo do ciclo de vida, enquanto as questões estudadas nas categorias de impacto ambientais, como uso de matéria prima, resíduos, energia e emissões de poluentes, perpassaram toda a cadeia através dos produtos vendidos e comprados e seus impactos.

A influência das relações entre dimensões mostrou-se de grande importância, como foi possível notar nas grandes quantidades de perdas e ganhos dentro de um mesmo processo, sendo um fator determinante dentro de alguns processos e operações, como na desconstrução final, onde a falta de internalização da sustentabilidade (dimensão cultural) pode trazer um impacto negativo em praticamente todas as dimensões dessa operação.

Em uma análise geral que pode ser vista na figura 52 da matriz síntese de cada processo concluise que o processo de produção florestal teve um bom desempenho da sustentabilidade com 
ganhos em todas as suas dimensões, com o pior desempenho na política, mas ainda conseguindo estabelecer relações de ganhos entre todas elas, internamente ao processo, onde ações positivas dentro de algumas categorias trouxeram ganhos de sustentabilidade não somente para esse, mas também para os outros processos envolvidos, diminuindo impactos de emissões de todo o ciclo de vida, e oferecendo matéria prima renovável.

No processo de beneficiamento houve de forma geral uma baixa sustentabilidade, com exceção da categoria de uso de energia, onde não foram encontrados ganhos de sustentabilidade internamente pela empresa, com um mau desempenho também nos ganhos devido a relações entre dimensões, contribuindo somente na dimensão ambiental ao longo do ciclo de vida.

O processo de construção apresentou o maior número de ganhos de sustentabilidade em suas relações entre dimensões, onde a experiência implementada a partir de uma visão pludimensional da sustentabilidade priorizou questões normalmente não abordadas, como o caráter participativo associado a questões sociais e econômicas.

As operações de manutenção e desconstrução apresentam o ponto de menor sustentabilidade de todo o ciclo de vida, onde não existem iniciativas de qualquer tipo para melhoria de sua sustentabilidade, tendo ainda sofrido perdas nas relações com outros processos e operações, como na escolha do tipo de madeira e na aplicação do tratamento preservativo.

Pode-se concluir de forma geral que a matriz de análise da sustentabilidade pode ser considerada um bom instrumento para visualização dos resultados finais, facilitando a apreensão dos pontos de maior e menor sustentabilidade em cada processo e dimensão, uma das metas a ser atingida por um método de análise da sustentabilidade. Porém, fica claro que não é possível adotar uma ferramenta como essa para servir de base para futuras escolhas de sistemas e processos construtivos mais sustentáveis, por ter simplificado demasiadamente uma relação tão complexa como a que foi estudada, onde mesmo um processo tendo muitos ganhos de sustentabilidade, apresentando um quadro geral positivo, pode apresentar um único fator que inviabiliza sua aplicação. Isso acontece pois a matriz levantada não apresenta ponderações de importância ou pesos para as questões levantadas, que muitas vezes ainda não são comparáveis. Assim confirmase que a utilização da matriz como ferramenta de organização e visualização dos dados tem um resultado positivo, enquanto a análise quantitativa, para as dimensões que podem ter seus valores absolutos comparados, e a qualitativa associada a indicadores, são os métodos de análise que mais se aproximam de um estudo pluridimensional equilibrado para formação de uma base comparativa confiável. 


\subsection{Verificação da integridade e consistência do trabalho.}

Essa etapa consiste no levantamento das etapas, dados, procedimentos e análises propostos para a pesquisa e que não foram realizados ou coletados, justificando suas causas, qual o procedimento adotado para a minimização das possíveis lacunas deixadas no presente trabalho e as propostas e sugestões para futuras aplicações desse método.

Dentro da primeira fase do método APCV, definição do objetivo e escopo, não foram identificados dentro das funções do sistema o desempenho do sistema estrutural em VLP contra incêndio, o qual pode ser feito em futuros trabalhos através da aplicação da norma específica sobre o assunto. Dentro do sub-item de definição da fronteira inicial do sistema, ressalta-se que, por falta de recursos financeiros e de tempo, não foram incluídos processos de produção de produtos tóxicos, como os defensivos agrícolas e preservativos da madeira, que segundo a norma ABNT 14041 devem ser incluídos por apresentarem potencial de impactos ao meio ambiente. Sugere-se então que nos futuros trabalhos, com um planejamento de longo prazo e com recursos para pesquisa, possam incluir esses e outros processos para atingir a recomendação da mesma norma de abranger todos os processos envolvidos de forma a se ter somente entradas de fluxos elementares.

$\mathrm{Na}$ fase de análise do inventário, destaca-se que o levantamento do processo de produção florestal não foi realizado na empresa que efetivamente participou do ciclo de vida do sistema em VLP, visto o seu desinteresse em contribuir com a pesquisa, resguardando seus direitos de não divulgar dados internos. Assim, adotou-se a estratégia de levantamento dos dados em outra empresa de produção florestal, estimando-se seus impactos caso localizasse no município onde foram produzidas as toras. Da mesma maneira, futuros trabalhos também poderão encontrar dificuldades para a coleta de dados de empresas que por algum motivo não divulgam seus dados ou não o fazem de forma transparente, podendo ser adotado o mesmo procedimento de estimativas por empresas de características semelhantes.

Durante o levantamento do inventário também não foi possível fazer o levantamento da energia consumida no processo de beneficiamento, estimada a partir da revisão bibliográfica, que, quando necessária, deve se aproximar do contexto existente na realidade analisada, para uma maior confiabilidade dos dados. Destaca-se também que muitos dos dados levantados foram obtidos através de entrevistas ou relatórios elaborados pela própria empresa, devido à falta de recursos financeiros para a coleta de todos os dados in loco. A confiabilidade desses dados poderia aumentar caso houvesse auditorias sobre eles, mas trata-se de um procedimento que demanda 
tempo e recursos, insuficientes nessa pesquisa de mestrado, que no entanto pode ser feito em futuros trabalhos.

$\mathrm{Na}$ etapa de avaliação dos impactos destaca-se a relação direta dos dados ao escopo delimitado e às bases de cálculo adotadas nos inventários, estando portanto sua consistência relacionada à do inventário. A comparabilidade dos dados das dimensões política e cultural está relacionada somente às questões qualitativas e sua relação com as diretrizes da sustentabilidade, sugerindo-se que novos trabalhos também adotem indicadores ponderados para facilitar sua análise e comparação.

De forma geral o trabalho manteve uma boa integridade vista a grande quantidade de dados a serem coletados e os poucos pontos onde não foram coletados os dados do objeto de estudo, sendo esses sempre estimados por bibliografias que se aproximavam das condições da realidade estudada e com legitimidade na área em que estavam inseridos, indicando também uma boa consistência do trabalho.

A última etapa da interpretação dos dados, a elaboração das conclusões, será feita no capítulo 6 de considerações finais, onde serão colocadas também algumas recomendações para futuros trabalhos. 


\section{Capítulo 6}

\section{Considerações finais}

Ao longo do trabalho foi possível fazer algumas verificações sobre os debates da sustentabilidade, seus métodos, as hipóteses e objetivos propostos, bem como sobre sua aplicação, resultados obtidos e análises feitas. Nesse capítulo serão elaboradas algumas considerações sobre as questões acima citadas, acrescentando-se as contribuições dessa pesquisa para as lacunas encontradas na literatura e para aplicações em futuros trabalhos e ações práticas.

Parte do terceiro objetivo intermediário, que se refere ao levantamento das diretrizes e conceitos da sustentabilidade, é atingido durante a revisão bibliográfica, onde foi possível verificar que as resoluções de problemas ambientais causados pelas ações antrópicas não estão ligadas somente a propostas tecnológicas, que muitas vezes se limitam a minimizar os danos já causados, mas estão ligadas diretamente à necessidade de mudança dos padrões sociais e culturais atuais. Foi possível identificar na literatura que um dos caminhos sugeridos pelos autores para se atingir as causas dos problemas, ou seja, os padrões socioculturais de alto consumo, é a divisão do poder, para tomadas de decisão mais equilibradas, apontando para os movimentos de participação popular, ou do terceiro setor, como forma de viabilizar essa proposta. Chegou-se então as diretrizes que propõem tratar o tema de forma pluridimensional e indissociável, abordando as dimensões ambiental, social, econômica, política e cultural.

O terceiro objetivo intermediário foi alcançado com o levantamento dos atuais métodos de análise da sustentabilidade, através de estudos que os analisam, onde a terceira hipótese foi confirmada, verificando-se que os métodos que procuram avaliar as experiências da construção civil a partir do viés da sustentabilidade não procuram analisar as complexas relações existentes na realidade em suas múltiplas dimensões, ainda se restringindo majoritariamente nas questões ambientais e a algumas etapas de sua cadeia produtiva. Constatou-se que um método que se aproxima de uma análise pluridimensional da sustentabilidade deve necessariamente avaliar seus ganhos e perdas entre suas dimensões e ao longo de todo ciclo de vida do produto estudado e por isso foi escolhido o método ACV como base para criação de um método de análise pluridimensional da sustentabilidade. 
Atingiu-se também o primeiro objetivo intermediário, confirmando-se sua hipótese intermediária através da associação do método ACV e dos Indicadores Ethos a variáveis levantadas na literatura sobre dimensões não abordadas por eles e a ferramentas desenvolvidas durante o trabalho, permitindo a formulação de um método que se aproxima da análise pretendida, nomeado de APCV, Avaliação Pluridimensional do Ciclo de Vida, que utiliza métodos consagrados e esforço de levantamento da realidade local para a elaboração de uma base comparativa mais confiável. Assim o método resultante possibilita, através do cruzamento de diferentes processos e dimensões, uma análise que capaz de abranger o maior número possível de relações existentes no objeto de estudo e seus ganhos e perdas ao longo da cadeia.

Ao se atingir o segundo objetivo intermediário, que é a sistematização do ciclo de vida e dos agentes envolvidos (nos capítulos 2 e 3), o trabalho cria uma base de dados para futuros estudos, não só do contexto local, mas do método para levantamento deste, através da sistematização dos processos do ciclo de vida do sistema estrutural em vigas laminadas pregadas, dos métodos de bases de cálculo e das categorias de impacto consagradas na literatura, organizando os dados de forma a se obter uma base de dados quantitativos e qualitativos fundamentados em critérios e diretrizes da sustentabilidade passíveis de comparação.

A verificação da hipótese principal, com respostas à pergunta principal, e o resultado do objetivo principal foram atingidos com a identificação dos pontos de maior e menor sustentabilidade ao longo do ciclo de vida, assim como as relações existentes entre as diferentes dimensões. Confirmou-se a hipótese de que esses processos ocorrem em relações de ganhos e perdas em determinados processos e operações que influenciam outros pontos da cadeia. Esses pontos de maior ou menor sustentabilidade foram descritos ao longo do capítulo 5 , dividindo-se em dimensões e processos.

As análises ambientais do sistema estrutural em vigas laminadas pregadas mostram que o uso da madeira serrada de plantios florestais como matéria prima para construção civil pode contribuir de forma significativa para o resgate de carbono da atmosfera, e conseqüentemente para a diminuição do efeito estufa. Considerando-se a capacidade das árvores em adquirir massa durante seu ciclo, possibilitando o fornecimento contínuo de matéria prima para a demanda da construção civil, aliada ao potencial de geração de energia calorífica dos seus resíduos (que resultou em um saldo de produção de energia para o objeto de estudo), destaca-se a madeira como matéria prima e fonte de energia permanente, renovável e mais sustentável, que utiliza poucos recursos naturais e abundantes, ao contrário da utilização de recursos escassos e não renováveis para esses fins. 
Para que haja um balanço positivo de energia no ciclo de vida é fundamental a utilização dos recursos locais, pois a queima de combustíveis fósseis para o transporte de matéria prima foi o item que mais consumiu energia calorífica em todo o processo.

Identificou-se como o pior ponto de sustentabilidade ambiental dentro desse ciclo de vida a utilização de tratamento preservativo com produtos tóxicos, relacionada às operações de manutenção e disposição final do sistema. Esse procedimento fez com que a matéria prima (madeira) de baixo impacto ambiental fosse contaminada havendo a necessidade de depositá-la em um aterro industrial para que a água e o solo não fossem contaminados, prática não indicada como sustentável, apesar de não apresentar danos ambientais se feita corretamente. Portanto para o aumento da sustentabilidade nesse processo poderiam ser estudadas três alternativas: utilização de tratamentos preservativos não tóxicos para o meio ambiente e para os humanos; utilização e monitoramento de um sistema estrutural sem tratamento preservativo, com facilidade de trocas de componentes atacados por insetos xilófagos; e utilização de madeira serrada proveniente de plantios florestais com espécies nativas mais resistentes ao ataque desses insetos.

Com relação às dimensões social e econômica, poder-se analisar três situações distintas ao longo da cadeia produtiva. A primeira situação trata-se das práticas socioempresariais encontradas no processo de produção florestal que proporcionam alta qualidade de vida para seus funcionários, seguindo padrões de qualidade com certificações internacionais quanto à educação, segurança no trabalho e formação profissional, expandidas aos seus fornecedores e monitoradas. Seu desempenho econômico segue uma lógica coerente com suas ações sociais, com uma boa distribuição de riquezas entre funcionários e com investimentos em áreas sociais e ambientais. Porém, o modelo econômico da empresa não é viável de ser reproduzido na realidade de países subdesenvolvidos (devido à necessidade de altos investimentos) sem que haja a interferência de agentes com grande concentração de capital, restringindo-o à minoria da população.

$\mathrm{Na}$ segunda situação a empresa do processo de beneficiamento apresentou índices de desempenhos sociais e econômicos baixos, pois, à medida que se restringe a seguir o modelo da legislação vigente, contribui-se para a manutenção do quadro social atual considerado de baixa sustentabilidade, onde grande parte da população mundial tem baixos índices de qualidade de vida e uma minoria concentra grandes riquezas.

A terceira situação aborda o processo de construção em sistema de mutirão e trocas de serviços com a marcenaria coletiva, onde, através do resgate de uma forma de organização não 
convencional, atingiu-se um bom desempenho social, com geração de trabalho e renda para populações carentes, produção de moradias de qualidade e formação dos envolvidos para serviços da construção civil, marcenaria e autogestão, causando um grande impacto positivo na comunidade local. A experiência também apresentou um bom desempenho no modelo econômico, utilizando recursos estatais e convênios com universidades para investir em pesquisas de busca de sustentabilidade, direcionados a populações carentes, e criando infra-estruturas básicas e empreendimentos para melhoria de qualidade de vida da comunidade.

Dentro da dimensão cultural verificou-se a contradição entre os posicionamentos de dois autores citados, onde de um lado se valoriza a manutenção dos padrões, espaços e formas de expressão utilizadas tradicionalmente por cada povo, e de outro se valoriza mudanças de comportamento frente aos atuais padrões insustentáveis da sociedade e sua cultura. Assim, a análise dessa dimensão considerou como mais sustentável a utilização do processo de mutirão e do sistema estrutural em VLP, fazendo-se a proposta de mudança nos padrões atuais, sem no entanto deixar de atender as expectativas culturais dos usuários, o que não ocorreu durante os dois primeiros processos, onde houve um predomínio da manutenção dos padrões vigentes de produção e utilização de materiais.

$\mathrm{Na}$ dimensão política, no processo de produção florestal, tem-se a aplicação de um modelo com baixa participação de funcionários nas instâncias de decisão, porém, em contrapartida, a empresa aplica uma política que visa o aumento da sustentabilidade, com adoção de relatórios e certificações para sua verificação. Já na empresa de beneficiamento, com a mesma estratégia de não participação dos funcionários nas decisões, o resultado foi uma baixa adoção de práticas e políticas mais sustentáveis, concluindo-se que esse modelo de tomada de decisões pode ou não resultar em políticas mais sustentáveis, dependendo de outros fatores envolvidos, tais como a política de propaganda da empresa, ou mesmo o grau de conscientização dos responsáveis pelas decisões estratégicas. No processo de construção foram adotadas novas formas de gerenciamento do projeto, onde se buscava a autogestão, contrapondo-se diferentes interesses e tomadas de decisões mais equilibradas, aumentando a sustentabilidade nas dimensões que mais afetavam essa população. A possibilidade de mudar a forma como as políticas são implementadas por uma população carente, que historicamente nunca teve poder de decisão, trouxe uma inversão no atual modelo de segregação, contribuindo para que a mesma fosse beneficiada.

No capítulo 5 foi confirmada a hipótese de que apesar do modelo de análise da sustentabilidade por dimensões contribuir para o entendimento de parte da realidade estudada, muitas questões só podem ser identificadas a partir da relação entre essas diferentes dimensões, etapa imprescindível 
para que a análise contemple a complexidade da realidade e para que se possa perceber como muitos impactos têm origem dentro de um mesmo processo, mas que até então não eram notados por não estarem diretamente relacionados à área ambiental ou social. Dentro do objetivo principal proposto foi possível identificar que muitas dessas relações são de ganhos e perdas mútuos de sustentabilidade, onde uma ação positiva influencia positivamente em outra dimensão, ou uma negativa, negativamente.

Portanto, foi possível identificar, durante o processo de produção florestal, ganhos de sustentabilidade nas dimensões social e ambiental em detrimento aos ganhos da dimensão econômica, através de suas relações. Os altos investimentos financeiros e o nível satisfatório de internalização da sustentabilidade (dimensão cultural) contribuíram para que se atingissem bons desempenhos nas dimensões ambiental e social, ainda que essa última tenha apresentado perda mútua de sustentabilidade em relação à política, considerando-se a não participação dos funcionários na tomadas de decisões.

Já no processo de beneficiamento a boa prática de associação com outras empresas do setor, relacionada à dimensão política, permitiu o aumento da transformação dos resíduos gerados nesse setor em matéria prima para geração de energia, caracterizando um ganho na sustentabilidade ambiental. Porém, ainda nesse processo, houve uma perda de sustentabilidade mútua em todas as dimensões devido à não internalização dessa questão dentro da empresa, significando que caso não haja um processo de conscientização não haverá mudanças na atuação das empresas para o aumento da sustentabilidade.

No processo de construção houve um ganho mútuo nas dimensões política, social, econômica e cultural, obtido pelo modelo de participação das famílias nos processos decisórios, apontado como um dos caminhos possíveis para se atingir uma maior sustentabilidade atualmente, pois, distribuindo-se o poder pelas partes interessadas de forma igualitária, pode-se confrontar os divergentes interesses e visões existentes, para que, através de encaminhamentos propostos seja possível atingir um estado da maior equilíbrio no planeta, com distribuição entre as partes dos ônus e bônus decorrentes de suas escolhas. As dimensões econômica, social e ambiental também tiveram ganhos mútuos de sustentabilidade, devido aos investimentos feitos por entidades governamentais na melhoria de qualidade de vida e nas pesquisas para desenvolvimento de técnicas e processos mais sustentáveis. A dimensão econômica também se relacionou com a cultural, considerando-se que a escolha por técnicas e meios de produção mais sustentáveis foi determinada pelo fator econômico, e não pela internalização da sustentabilidade na dimensão cultural, devendo-se atentar para a sua fragilidade que, apesar de condizente com as condições 
financeiras daquela situação, não pode ser considerada capaz de manter as práticas de sustentabilidade a longo prazo. Essa questão também está refletida na perda mútua de sustentabilidade nas dimensões ambiental, cultural, econômica e política durante as operações de manutenção, desconstrução e disposição final, supondo-se um cenário provável de não internalização da sustentabilidade pelas famílias usuárias do sistema estrutural em VLP, onde o tratamento preservativo não seria aplicado e a sua disposição final seria feita de forma não apropriada (em solo nu). Essa hipótese parte do histórico dos critérios de escolhas, por parte das famílias, baseados a priori somente em fatores econômicos, prevendo-se que suas ações durante a manutenção e disposição final do sistema estrutural seguiriam as mesmas considerações, o que poderia ocasionar impactos em outras dimensões. Para evitar esse quadro é importante que haja uma conscientização dos usuários quanto aos impactos que suas ações poderão causar e as conseqüências para cada um, comunidade e sociedade.

Como análise final notou-se que a abrangência e grande quantidades de variáveis e dados relacionados não podem ser demasiadamente simplificados, com o intuito de ampliar sua divulgação ou facilitar sua apreensão, sub risco de ocultar algumas importantes relações que refletiriam de forma mais clara a complexa análise que deve ser feita.

Atingindo-se os objetivos com a confirmação das hipóteses iniciais e preenchimento das lacunas apontadas pelas perguntas de pesquisa, o trabalho coloca-se como uma base, ou um estudo, que poderá ser utilizado em novas avaliações de sustentabilidade. Apesar das contribuições que o trabalho oferece no tema da sustentabilidade, resgate de conceitos, avaliação de métodos e proposição de um método pluridimensional, acredita-se que muitas contribuições ainda deverão ser acrescentadas, algumas apontadas dentro das verificações de consistência do método, para que se possa analisar uma realidade tão complexa de forma mais precisa, através de ferramentas simples e possíveis de serem utilizadas por pesquisadores e outros profissionais, sem inviabilizar os estudos pela sua amplitude. Propõe-se também que a partir do método criado possam ser feitas novas análises, em diferentes sistemas construtivos ou até mesmo em habitações, possibilitando a comparação entre dois objetos escolhidos, pois, como já dito anteriormente, a sustentabilidade é um termo relativo, determinada pela comparação de duas ou mais experiências, e nunca absoluto.

Por fim, o trabalho deixa a possibilidade de se criar um banco de dados a partir da experiência estudada, servindo como base comparativa para novas experiências, capaz de identificar, através do método proposto, as melhores práticas para cada contexto, guiando assim o setor da construção civil para uma atuação mais sustentável no planeta. 


\section{Bibliografia}

AGÊNCIA NACIONAL DE VIGILANCIA SANITARIA (2007). Consulta Pública no 64, de 11 julho de 2007. Disponível em: http://www4.anvisa.gov.br/base/visadoc/CP/CP\%5B190721-0\%5D.PDF. Acesso em 02/05/2008.

AGÊNCIA NACIONAL DO PETRÓLEO. (2006). Anuário estatístico de 2006. Disponível em: http://www.anp.gov.br/conheca/anuario_2006.asp. Acesso em: 20/09/2007.

ARRUDA, M. P. (2000). Diretrizes para projeto arquitetônico de habitação social em Pinus produzida por mutirão. São Carlos. Dissertação de mestrado em Arquitetura - EESC, Universidade de São Paulo.

ASSOCIAÇÃO BRASILEIRA DE NORMAS TÉCNICAS (2008). NBR 15575-1: Edifícios habitacionais de até cinco pavimentos - Desempenho - Parte 1: Requisitos gerais. Rio de Janeiro.

ASSOCIAÇÃO BRASILEIRA DE NORMAS TÉCNICAS (2008). NBR 15575-2: Edifícios habitacionais de até cinco pavimentos - Desempenho - Parte 2: Requisitos para os sistemas estruturais. Rio de Janeiro.

ASSOCIAÇÃO BRASILEIRA DE NORMAS TÉCNICAS (2008). NBR 15575- 5: Requisitos para sistemas de coberturas. Rio de Janeiro.

ASSOCIAÇÃO BRASILEIRA DE NORMAS TÉCNICAS (2004). NBR 16001: Responsabilidade social - Sistema de gestão - requisitos. Rio de Janeiro.

ASSOCIAÇÃO BRASILEIRA DE NORMAS TÉCNICAS (1997). NBR 7190: Projeto de estruturas de madeira. São Paulo.

ASSOCIAÇÃO BRASILEIRA DE NORMAS TÉCNICAS (2001). NBR ISO 14040: Avaliação de ciclos de vida, princípios e estrutura. Rio de Janeiro.

ASSOCIAÇÃO BRASILEIRA DE NORMAS TÉCNICAS (2004). NBR ISO 14041: Avaliação de ciclos de vida, definição de objetivo e escopo e análise de inventário. Rio de Janeiro.

ASSOCIAÇÃO BRASILEIRA DE NORMAS TÉCNICAS (2004). NBR ISO 14042: Avaliação de ciclos de vida, avaliação de impacto de ciclo de vida. Rio de Janeiro.

ASSOCIAÇÃO BRASILEIRA DE NORMAS TÉCNICAS (2005). NBR ISO 14043: Avaliação de ciclos de vida, interpretação do ciclo de vida. Rio de Janeiro.

AZEVEDO, V. K. de; et al (2007). Efeito alelopático de extrato de eucalyptus citrodora e Pinus elliottii sobre a germinação de Lactuca Sativa L. (Alface). In: VIII Congresso de ecologia do Brasil. Anais.... Caxambu/ MG. 
BARBOSA, J. C. (2003). Caracterização e avaliação do fluxo produtivo da habitação em madeira de plantios florestais segundo indicadores de sustentabilidade : consumo de energia e resíduos gerados. Tese (Doutorado). Escola de Engenharia de São Carlos Universidade de São Paulo. São Carlos.

BARKENS, W. (2003). Comparation of four life cycle based environmental assessment tools of buildings, real estates and infrastructures, In: Sustainable building, 3. Oslo. Proceedings... Oslo: Ecobuild. [CD].

BAKENS, W. (2003). Realizing the sector's potential for contributing to sustainable development. Industry and environment. Paris, v26, n 2-3, p.9-12, abr-set.

BARTHOLOMEU, D. B. (2006). Quantificação dos impactos econômicos e ambientais decorrentes do estado de conservação das rodovias brasileiras. Tese (doutorado) - Escola Superior de Agricultura “Luiz de Queiroz", Universidade de São Paulo, Piracicaba, 2006.

BIZON, J. M. C. (2005). Avaliação da sustentabilidade nutricional de plantios de Pinus taeda 1. usando um balanço de entrada-saída de nutrientes. Dissertação (Mestrado) Universidade de São Paulo, 80 f. Piracicaba.

BOURSCHEID, K et al (2003). Re-infestação de Pinus spp em área sujeita a restauração ambiental no parque florestal do rio vermelho, Florianópolis, SC. In: Seminário nacional de degradação ambiental. Disponível em: http://www.sobrade.com.br/eventos/2003/seminario/Trabalhos/007.pdf. Acesso em 15/03/2008.

BRAND, M. A.; COSTA, V. J. da; DURIGON, A.; AMORIN, M. (2004). Determinação das Propriedades Energéticas de Resíduos de Madeira em Diferentes Períodos de Armazenamento. Disponível em: http://www.tractebelenergia.com.br/uploads/p\&d/2004/0403-018-2004.pdf. Acessado em: 20/09/2007.

BRASIL. (1993). Lei No 8.723, de 28 out. 1993. http://www.lei.adv.br/8723-93.htm - Acessado em 20/08/2007.

CANDIAN WOOD COUNCIL. (1997). Athena, un modèle informatique permet de comparer les effets des matériaux de construction sur l'environment. In: Wood le Bois, n. 19, 31 p.

CIB. (1999). Agenda 21 on Sustainable Construction. Rotterdam: CIB, 120p. [CIB Report Publication 237].

CIB. (2000). Agenda 21 para a construção sustentável. trd. De I. Gonçalves, T. Whitaker; ed. de G. Weinstok, D.M. Weinstok. - São Paulo: [s.n.].

CIB e UNEP-IETC. (2002). Agenda 21 for sustainable Construction in Developing Countries. Pretoria, África do Sul: CSIR Building and Construction Technology, [documento para discussão].

CHAUI, M. de S. (1982). O que é ideologia. São Paulo : Ed. Brasiliense. 
CONAMA (2002). RESOLUÇÃO $\mathbf{N}^{\mathbf{o}}$ 307. Disponível em: http://www.mma.gov.br/port/conama/res/res02/res30702.html Acessado em 20/04/2008.

CUSTODIO, A. L. de M.; MOYA, R. (2007). Indicadores ETHOS de responsabilidade social empresarial 2007. São Paulo: Instituto ETHOS.

DEAKIN, M. et al. (2002). The assessment of sustainable urban development. In: Building Research \& Information. Vol2 n.30 95 - 108p.

DIEGUES, A. C. S. (1992). Desenvolvimento sustentável ou cidades sustentáveis: da crítica aos modelos aos novos paradigmas. In: São Paulo em Perspectiva: Desenvolvimento e meio ambiente. São Paulo: Fundação SEADE, vol. 6, 1 e 2, p. 22 - 29.

ESTEVES, A. M. C. et al. (2006). Guia de elaboração do balanço social. Instituto ETHOS São Paulo: Editora Margraf.

FERREIRA, M. C.; SOUZA, J. R. P. de; FAVIA, T. de J. (2007). Potenciação alelopática de extratos vegetais na verminação e no crescimento inicial de picão-preto e alface. Disponível em: http://www.scielo.br/pdf/cagro/v31n4/17.pdf Acessado em 10/01/2008.

FERSOL, (2004). Ficha de Informação de Segurança de produto Químico. Disponível em: http://www.fersolna.com.br/fersol/fichas/fispq/Cipermetrina300CE.pdf Acesso em 02/05/2008.

FOOD AND AGRICULTURE ORGANIZATION OF THE UNITED NATIONS (1985). FAO Specifications for plant protection products. Disponível em: http://www.fao.org/ag/AGP/AGPP/Pesticid/Specs/docs/word/CYPE.DOC Acesso em 02/05/2008.

FUNDAÇÃO JOÃO PINHEIRO. (2006). Déficit habitacional brasileiro no 2005. Disponível em: http://www.fjp.gov.br/produtos/cei/infocei_deficitbr2005.pdf. Acesso em 28/10/2007.

GAVA, M. (2005). Viabilidade técnica e econômica da produção de componentes para habitação social utilizando madeira serrada de Pinus de terceira classe de qualidade. São Carlos. Dissertação (Mestrado) - Programa de pós-graduação em Arquitetura e Urbanismo da Escola de Engenharia de São Carlos - Universidade de São Paulo.

GLOBAL REPORTING INITIATIVE (GRI). (2002). Sustainability Reporting Guidelines. 104pp. [S.l.:s.n.].

GONÇALVES, M. T. (2000). Exploração florestal, desenvolvimento e sociedade. In: HENRI ACSELRAD (org.). Meio ambiente e Democracia. Rio de Janeiro: IBASE. P. $70-87$.

IBAMA (2007). Lista de produtos registrados. Disponível em: http://www.ibama.gov.br/qualidadeambiental/madeira/produtos_reg_ibama.pdf Acessado em 20/04/2008.

INO, A., SHIMBO, I. (1998). Diretrizes e infra-estruturas para implantações de conjuntos habitacionais de interesse social, utilizando madeira de rejeito comercial. In: ENCONTRO 
NACIONAL DE TECNOLOGIA DO AMBIENTE CONSTRUÍDO, 7., 1998. Florianópolis. Anais...: NPC/ECV/CTC/UFSC, 1998. v. 4, p. 185-194.

INTERGOVERNMENTAL PANEL ON CLIMATE CHANGE. (1996). Revised 1996 IPCC Guidelines for National Greenhouse Gas Inventories. Disponível em: http://www.ipccnggip.iges.or.jp/public/gl/invs1.htm. Acesso em: 20/10/2007.

INTERNATIONAL PROGRAMME ON CHEMICAL SAFETY (1995). Chemical Safety Information from Intergovernmental Organizations. Disponível em: http://www.inchem.org/documents/pims/chemical/pim163.htm\#SubSectionTitle:7.2.5. Acesso em $07 / 10 / 2007$.

KRONKA,F.J.N.; BERTOLANI,F.; PONCE,R.H. A cultura do Pinus no Brasil. São Paulo: Sociedade Brasileira de Silvicultura, 2005

LAYRARGUES, P. P. (1997). Do ecodesenvolvimento ao desenvolvimento sustentável: evolução de um conceito? In: Proposta. Rio de Janeiro: FASE, nº 71, p. 5 - 10.

LEROY, J. P. et al. (2002). Tudo ao mesmo tempo agora: desenvolvimento, sustentabilidade, democracia: o que isso tem a ver com você? Petrópolis: Vozes. 198p.

LYLE, J. T. (1994). Regenerative design for sustainable development. Nova York: Wiley. $338 \mathrm{p}$.

LOUREIRO, L. N. (2005). Panorâmica sobre Emissões Atmosféricas Estudo de Caso: Avaliação do Inventário de Emissões Atmosféricas da Região Metropolitana do Rio de Janeiro para Fontes Móveis. Tese, (Mestrado) - COPPE, Universidade Federal do Rio de Janeiro, Rio de Janeiro.

MACÊDO, R. F. (2004). Inventário de emissões de dióxido de carbono (CO2) geradas por fontes móveis no estado do Rio Grande do Norte - Período de janeiro de 2003 a junho de $2004 . \quad$ Disponível em: http://www.ctgas.com.br/informacoes/publicacoes/Inventario_Emissoes_CO2_geradas_Fonte s_moveis.pdf. Acesso em 05/10/2007.

MAFRA, O.; EIDELMAN, F.; ALVIM, C. F. (2006). Avaliação das Emissões de CO2 pelo Uso do Processo "Top-Down Estendido" entre 1970 e 2004. In: Economia \& Energia, no 35, p.10 - p.32, novembro 2006. Disponível em: http:/ /ecen.com. Acesso em: 10/06/2007.

MAHMOUD, A. G. E.; et al (200-). Invasão de Pinus Elliottii em um fragmento de cerrado em Itirapina/SP. Disponível em: http://www.ib.unicamp.br/profs/fsantos/relatorios/bt791r2a2003.pdf. Acesso 02/03/2008.

MARTINS, V. A. (1998). Secagem da madeira serrada. Brasília: IBDF / DPq-LPF. 56 p.

PARTEL, P. M. P. (2006). Painéis estruturais utilizando madeira roliça de pequeno diâmetro para habitação social : desenvolvimento do produto. Tese (Doutorado). Escola de Engenharia de São Carlos - Universidade de São Paulo. São Carlos. 
PAULA, J. A., BRITO, F. R. A., AMARO, J. J. V., NABUCO, M. R. (1997). Fundamentos históricos e metodológicos da questão ambiental. In: Biodiversidade, população e economia. Belo Horizonte: UFMG / Cedeplar; ECMXC; PADCT / CIAMB. p. $202-255$.

PINHEIRO, R. V. (1996). Emprego da madeira do gênero Pinus na construção de estruturas de cobertura. São Carlos. Dissertação (Mestrado) - Escola de Engenharia de São Carlos, Universidade de São Paulo.

RELATÓRIO FINAL FASE 2 DE PROJETO DE PESQUISA. (2004). Habitação social em madeira como alternativa econômica para usos múltiplos da floresta. São Carlos: Habis EESC/USP. 2004.

RELATÓRIO TRIMESTRAL DO PROJETO DE PESQUISA. (2005). Construindo habitação rural, com recursos locais e renováveis, e ampliando as oportunidades de trabalho e renda: Assentamento Fazenda Pirituba (Itapeva - SP). São Carlos: Habis EESC/USP.

SACHS, I. (1986). Ecodesenvolvimento: crescer sem destruir. São Paulo: Vértice.

SACHS, I. (1993). Estratégia de transição para o século XXI: desenvolvimento e meio ambiente. Tradução de Magda Lopes. São Paulo. Studio Nobel, Fundação do Desenvolvimento Administrativo.

SACHS, W. et al (2002). O Memorando de Johannesburgo. Justiça num mundo frágil: Memorando para a Cúpula Mundial sobre Desenvolvimento Sustentável. Disonível em: http://www.worldsummit2002.org/download/MemoPtgInternet.pdf Acesso em 23/ 03/2007.

SANTOS, M. (1994). A urbanização brasileira. 2. ed. São Paulo: Hucitec. 157 p.

SANTOS, M. E. dos (1996). Algumas considerações acerca do conceito de sustentabilidade: suas dimensões política, teórica e ontológica. In: RODRIGUES, Arlete org. (1996). Desenvolvimento sustentável, teoria, debates, aplicações. Departamento de Sociologia/ Instituto de filosofia e Ciências Humanas IFCH/UNICAMP.

SAVASTANO, H. J. (2001). Uma cobertura em fibro-cimento vegetal. Revista Habitare. Ano 1 Agosto.[S.l.].

SHIMBO, L. Z. (2003). A casa é o pivô : mediações entre o arquiteto, o morador e a habitação rural. Dissertação (Mestrado). Escola de Engenharia de São Carlos - Universidade de São Paulo. São Carlos.

SILVA, F. M. G. da (2007). Análise da sustentabilidade no processo de produção de moradias utilizando adobe e bloco cerâmico : caso do assentamento rural Pirituba II Itapeva-SP. Dissertação (Mestrado). Escola de Engenharia de São Carlos - Universidade de São Paulo. São Carlos.

SILVA, F. M. da; Lopes, A.; Castro N. P.; Dabdoub, M. J.; Salvador, N.; Silva, R. P. da. (2007). Avaliação do Desempenho do Motor de Combustão Alimentado com Diesel e Biodiesel. In: II Congresso da Rede Brasileira de Tecnologia do Biodiesel. Disponível em: http://www.biodiesel.gov.br/docs/congressso2006/Outros/AvaliacaoDesempenho8.pdf Acessado em 10/02/2008. 
SILVA, P. R. S da. (2003). Avaliação de impactos e custos ambientais em processos industriais - uma abordagem metodológica. 191 p. Dissertação (engenharia de produção) Escola de Engenharia. Universidade Federal do Rio Grande do Sul. Porto Alegre.

SILVA, S. M. (2000). Indicadores de sustentabilidade urbana: as perspectivas e as limitações da operacionalização de um referencial sustentável. Dissertação (Mestrado), Universidade Federal de São Carlos, São Carlos.

SILVA, V. G da. (2003). Avaliação de Edifícios: Definição de Indicadores de sustentabilidade. In: III Encontro Nacional sobre Edificações e Comunidades Sustentáveis, 2003, São Carlos. Anais... São Carlos: USP.

SILVA, V. G. (2002). Green Building Challenge 2002: Report of the Brazilian Team. In: Green Building Challenge. Oslo: ISBE. [CD].

SOARES, R. S. et al. (2006). A avaliação do ciclo de vida no contexto da construção civil. In: COLETÂNIA HABITARE. Vol 7. Disponível em: < http://habitare.infohab.org.br/ArquivosConteudo/ct_7_cap4.pdf. Acesso em: 03/01/2007.

SOCIEDADE BRASILEIRA DE SILVICULTURA (2007), Fatos e números do Brasil florestal 2006. São Paulo [CD].

SPERB, M. R. e SATTLER, M. A. (2000). Avaliação de tipologias habitacionais a partir da caracterização de impactos ambientais relacionados a materiais de construção. Porto Alegre: 130p. Dissertação de mestrado - Universidade Federal do Rio Grande do Sul.

VALLE, I. M. R. do; GARCIA, J.N.(2007) Vigas laminadas pregadas como componentes estruturais de cobertura. In: VIII Conferência Internacional de Materiais e Tecnologias NãoConvencionais. Anais... Maceió.

ZILLER, S. R; Galvão, F. (2000). A degradação da estepe gramíneo-lenhosa no paraná por contaminação biológica de Pinus Elliottii e P. taeda. Disponível em: http://www.institutohorus.org.br/download/artigos/Revista\%20Floresta.pdf. Acesso em: 20/02/2008.

YIN, Robert K. (2001). Estudo de caso: planejamento e métodos. Porto Alegre: Bookman.

YUBA, A. N. (2005). Abordagem pluridimensional da sustentabilidade da cadeia produtiva da habitação em madeira de plantios florestais. Tese (Doutorado), Escola de Engenharia de São Carlos, Universidade de São Paulo. São Carlos. 
Anexo I 


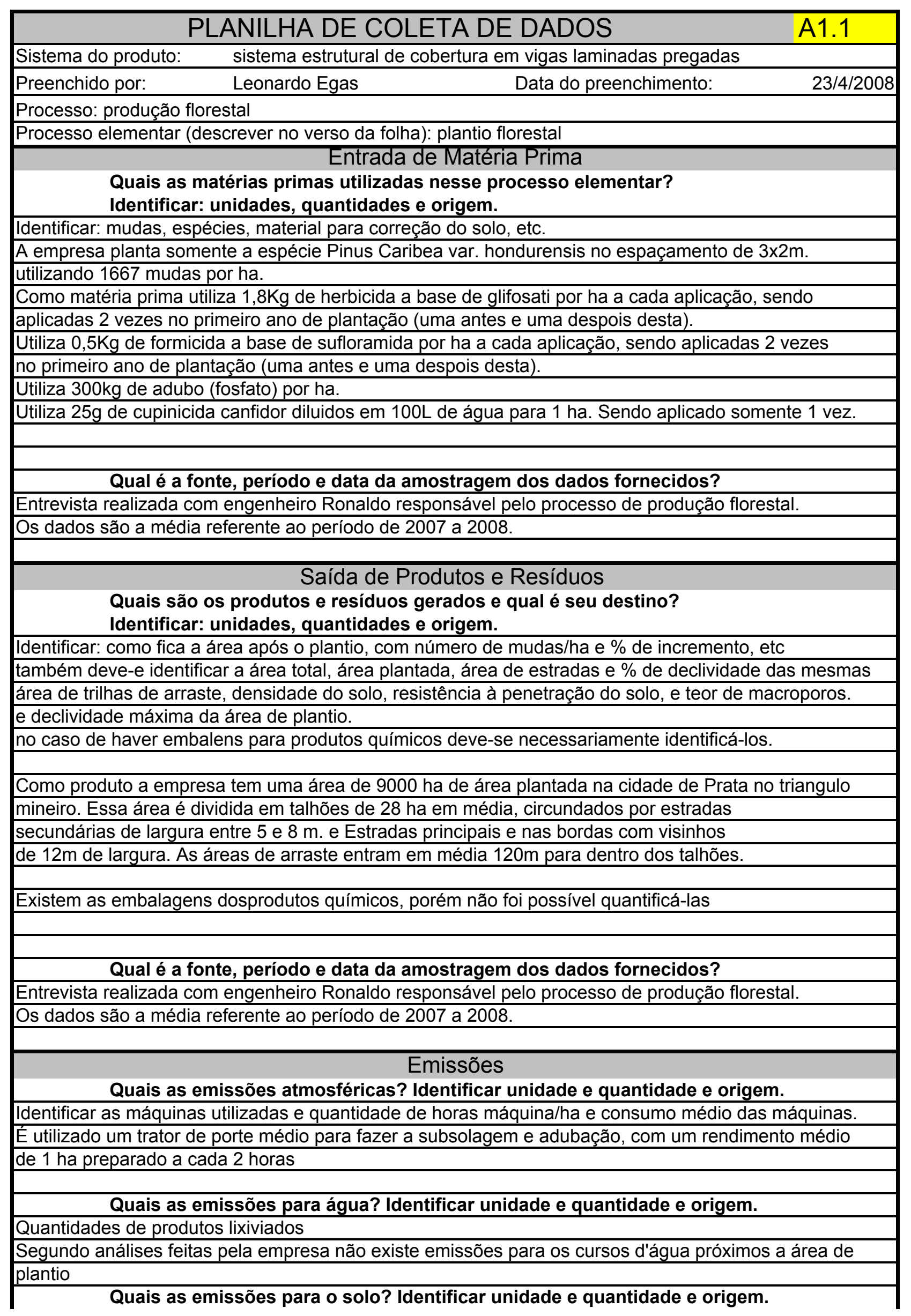


Quantidades de produtos lixiviados

Não são feitas análises de emissões para o solo.

Qual é a fonte, período e data da amostragem dos dados fornecidos?

Entrevista realizada com engenheiro Ronaldo responsável pelo processo de produção florestal.

Os dados são a média referente ao período de 2007 a 2008.

Transporte de matérias primas (rod., fer., etc):

\begin{tabular}{|l|l|l|l|l|} 
Nome do produto intermediário & Dist. $(\mathrm{Km})$ & Capacidade & Carga real & retorno vazio?
\end{tabular}

\begin{tabular}{|c|l|l|l|l|}
\hline & de 14 a 35 & & & \\
\hline & & & & \\
\hline & & & & \\
\hline & & & & \\
\hline & & & & \\
\hline
\end{tabular}

\section{Energia}

Qual o consumo de energia nesse processo elementar (elétrica, combustível fóssil)?

Identificar: unidades, quantidades, origem e destino.

Identificar máquinas utilizadas no processo e seu consumo de energia ou comb. Fóssil

É utilizado um trator de porte médio para fazer a subsolagem e adubação, com um rendimento médio de 0,5 ha preparado por hora

Qual é a fonte, período e data da amostragem dos dados fornecidos?

Entrevista realizada com engenheiro Ronaldo responsável pelo processo de produção florestal.

Os dados são a média referente ao período de 2007 a 2008.

\section{Água}

Qual o consumo de água nesse processo elementar?

Identificar: unidades, quantidades, origem e destino.

Utiliza água para irrigação em alguma etapa do manejo?

Fonte de abastecimento (poço, sisterna, rede pública, etc.)

Utiliza água para diluição do cupinicida, 84 por ha. Não utiliza processo de irrigação.

Qual é a fonte, período e data da amostragem dos dados fornecidos?

Entrevista realizada com engenheiro Ronaldo responsável pelo processo de produção florestal.

Os dados são a média referente ao período de 2007 a 2008.

\section{Observações}

Indicar quantidade de arvores / ha durante o plantio, antes do desbaste, depois do desbaste e antes

da colheita.

Identificar se a plantação está localizada próxima a áreas ambientalmente frágeis.

O processo de plantio é composto pelas seguintes etapas.

1- Controle de pragas com aplicação de furmicida granular a base de sufloramida (atamex),

e herbicida granular a base de glifosati (escalti) diretamente no solo.

2 - aplicação de cupinicida líquido (canfidor) nas mudas através de imersão

3- Preparação do solo através da subsolagem com um trator que faz os "riscos" a cada 3m

a uma profundidade de $40 \mathrm{~cm}$, e aplica automaticamente a adubação do solo com fosfato.

4- As mudas são posicionadas dentros dos "riscos" em um espaçamento de $2 \mathrm{~m}$, finalizando a etapa. 


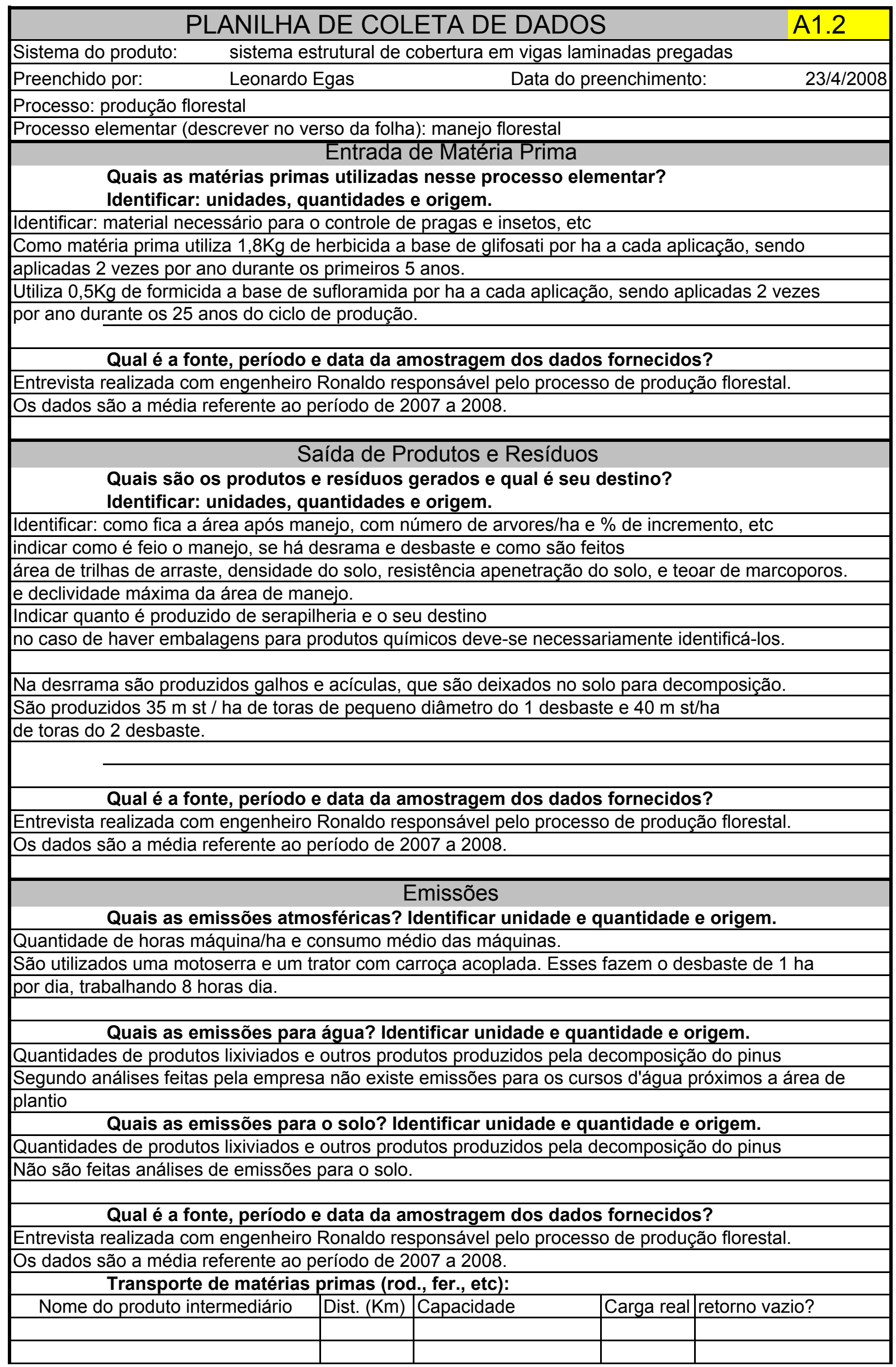




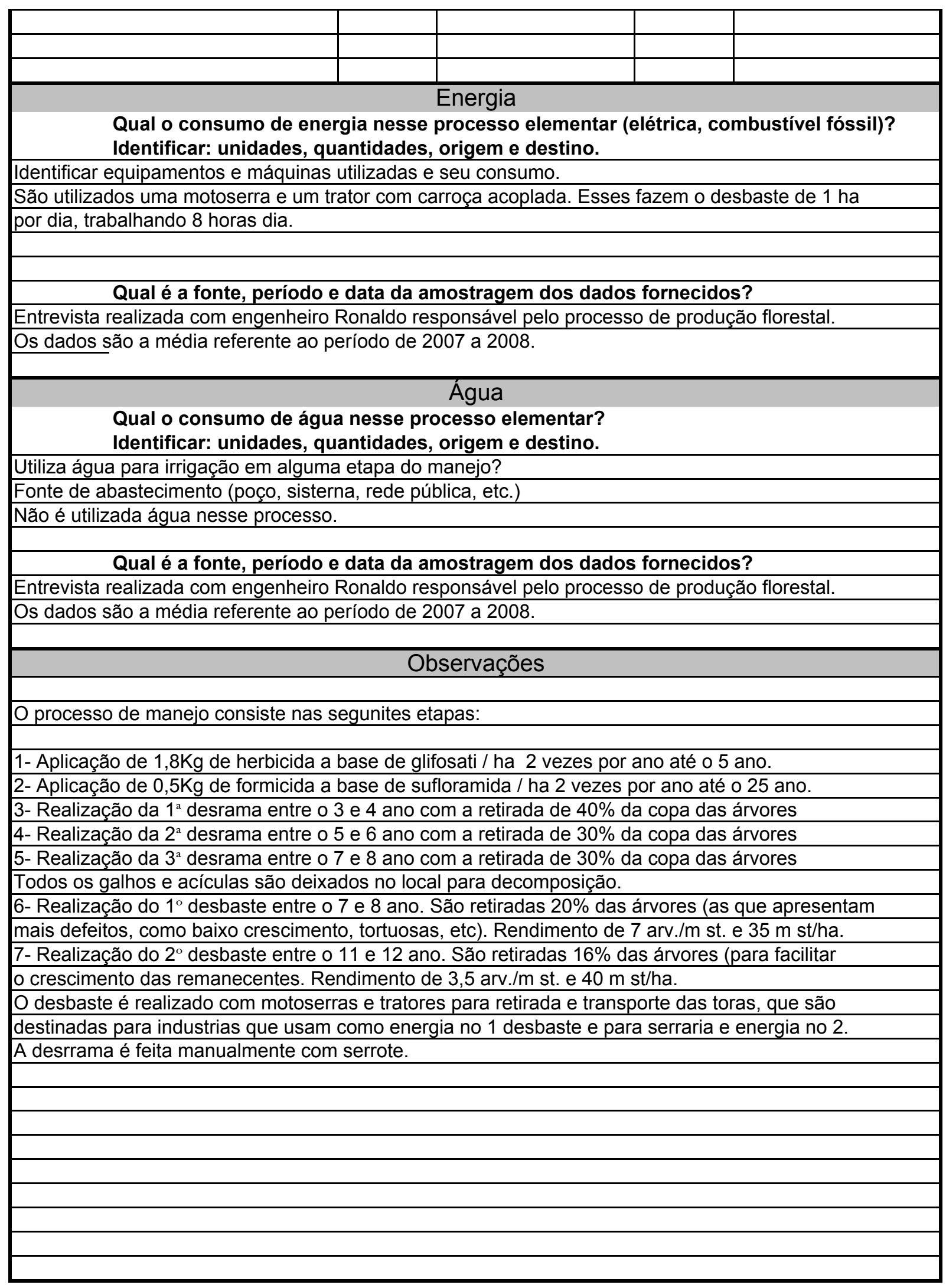




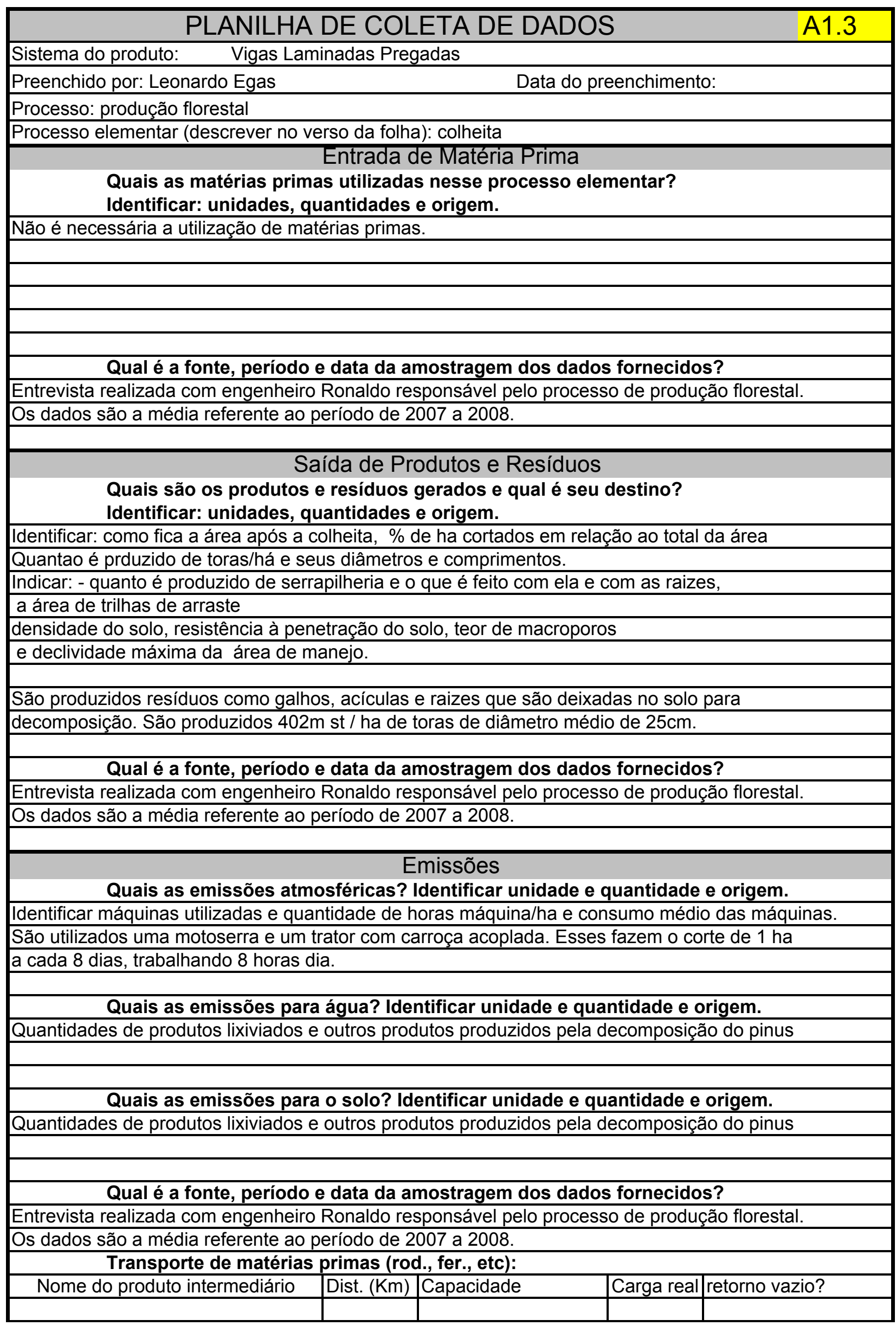




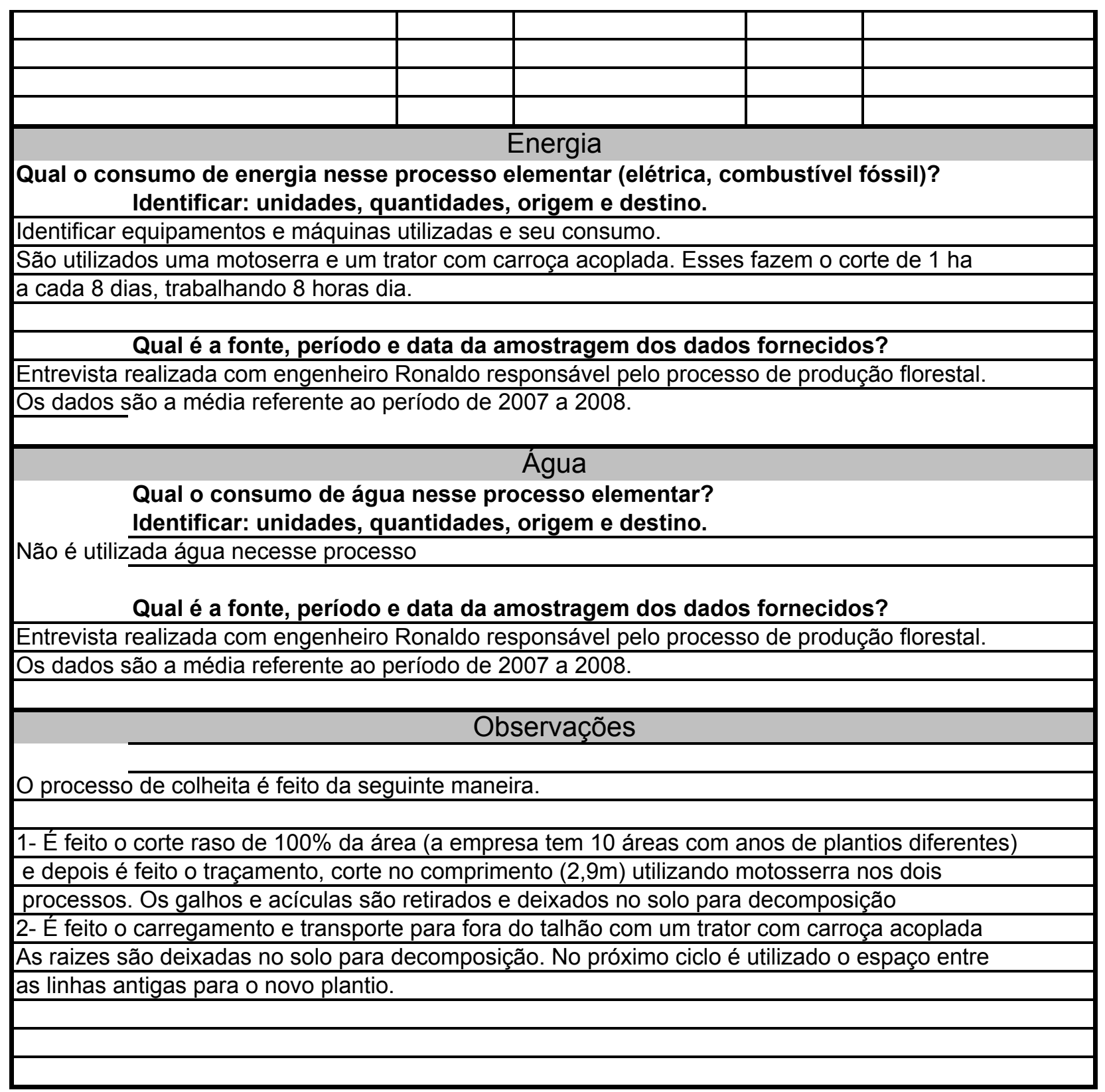




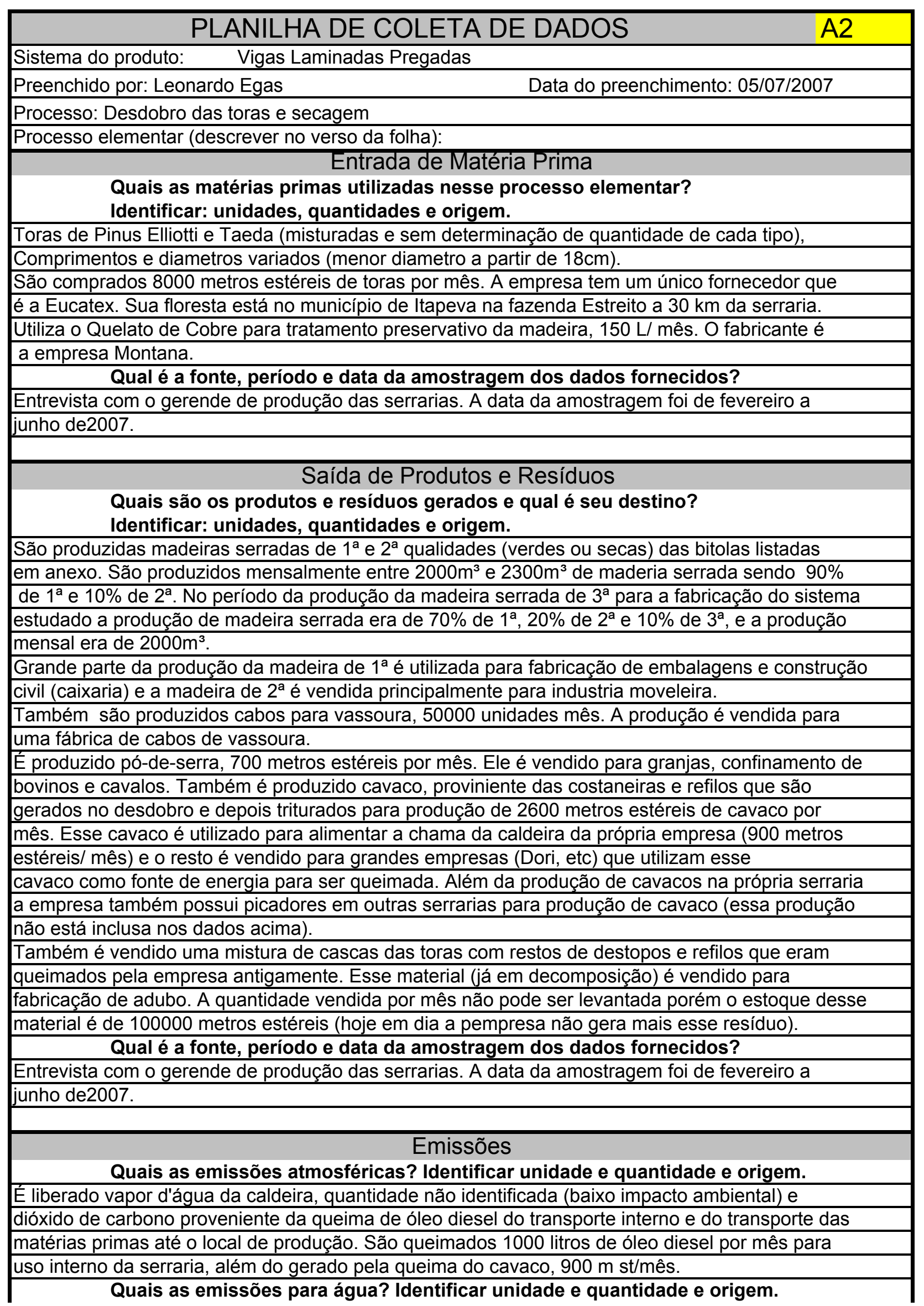




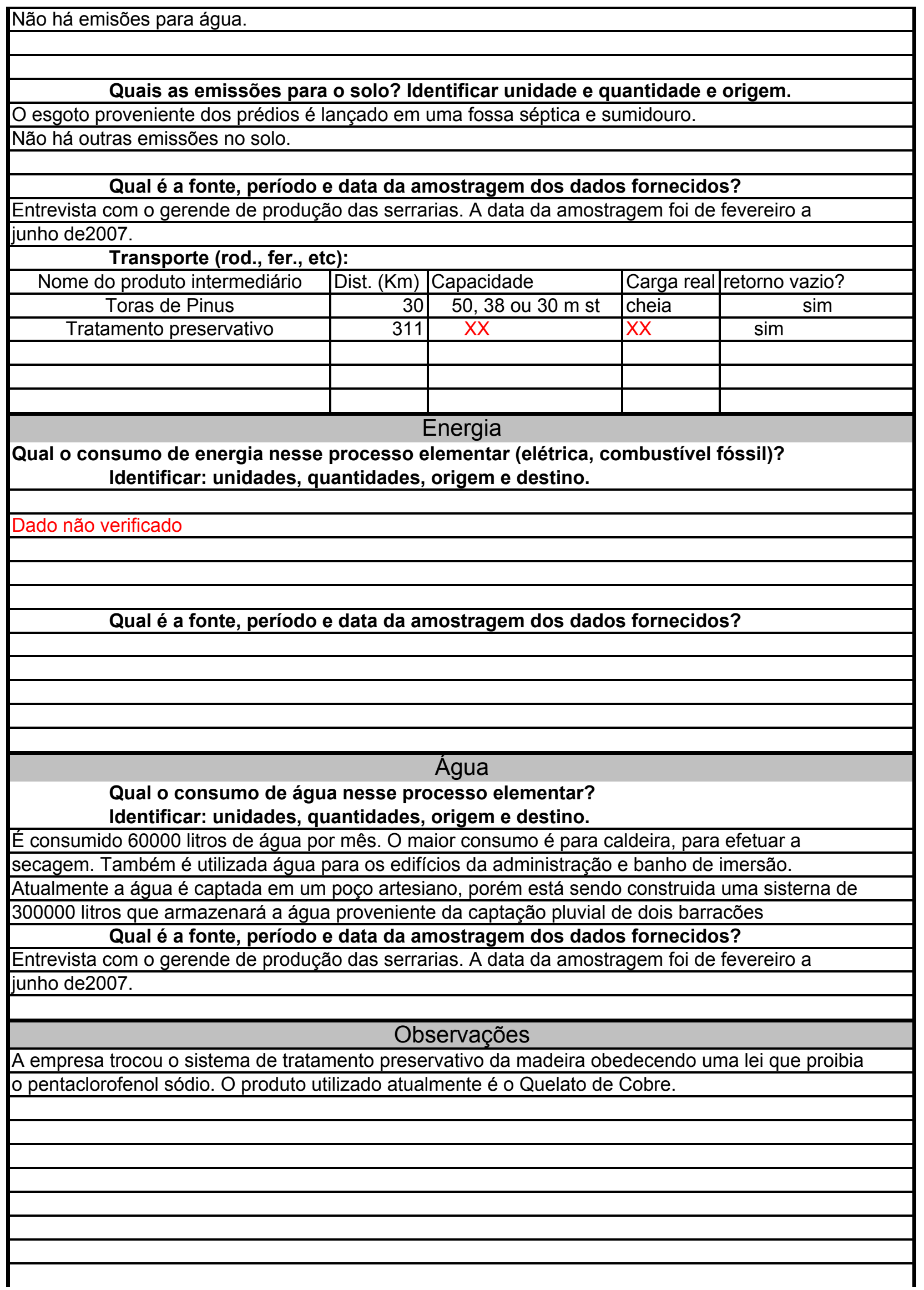




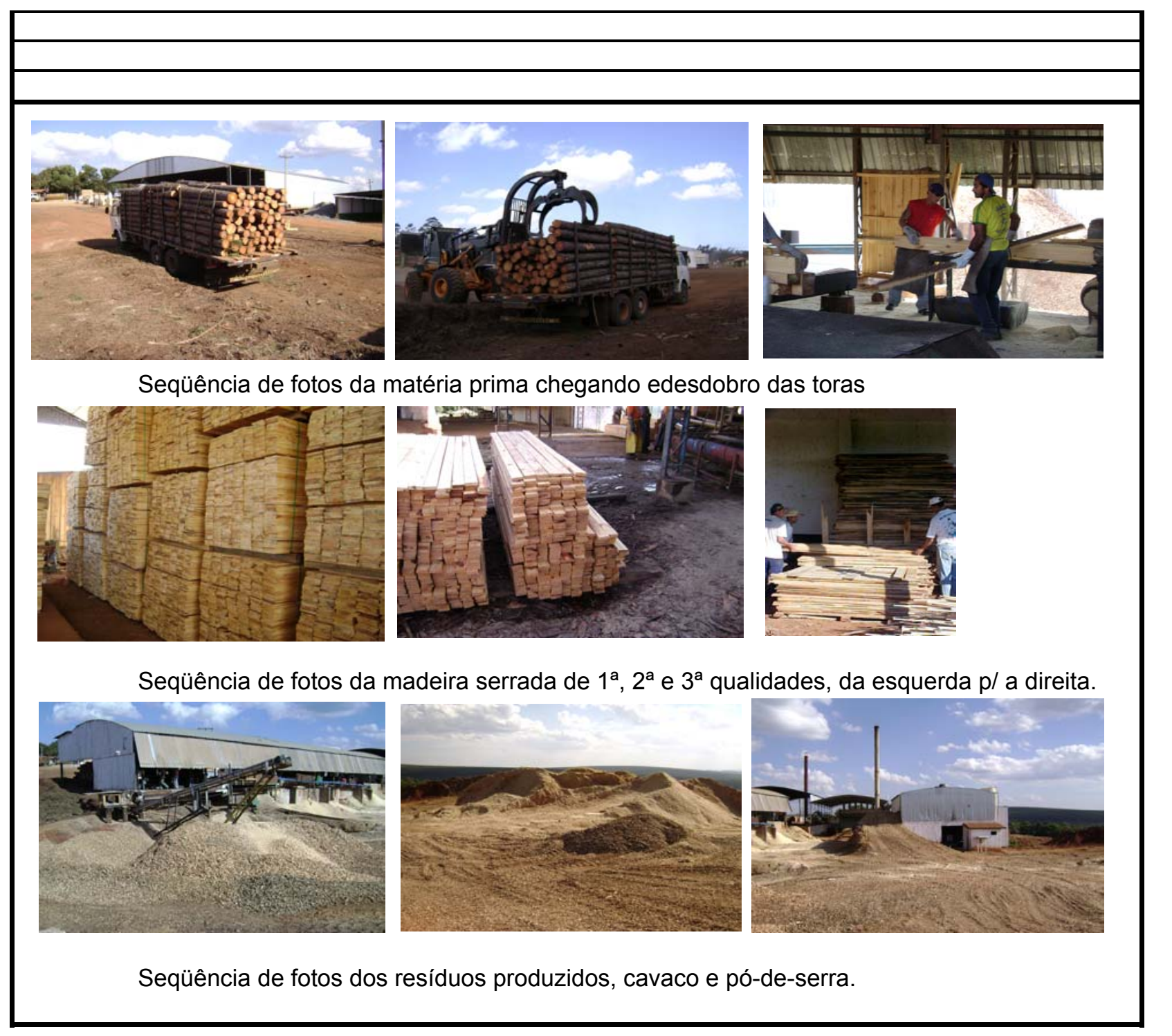




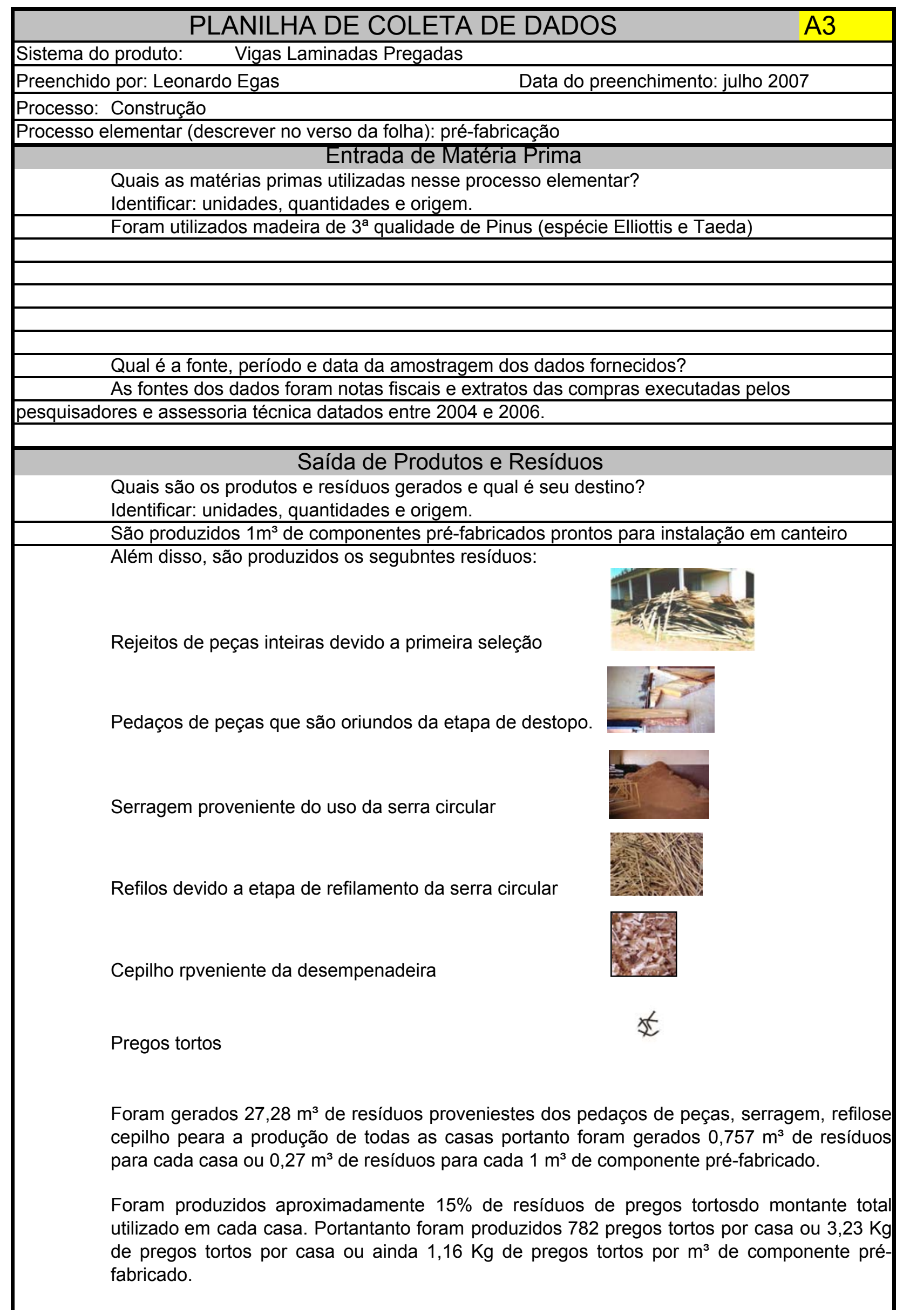


Qual o destino dos resíduos gerados?

As peças rejeitadas na primeira seleção ainda foram utilizadas na marcenaria para outros fins, principalmente na utilização de peças curtas.

A serragem e o cepilho eram vendidos para forração de chiqueiros e de criação de galinhas, essa forração pode ser utilizada posteriormente como adubo.

Os refilos e destopos estão armazenados em uma área próxima a marcenaria. Caso esses não tiverem side expostos ao tratamento preservativo poderão ser devolvidos ao solo para ser

Os pregos tortos foram armazenados em umlocal dentro da marcenaria e poderão ser vendidos para o ferro velho a fim de ser feita uma reciclagem.

Qual é a fonte, período e data da amostragem dos dados fornecidos?

A fonte dos dados foi o regate dos registros, entre 2004 e 2006, dos pesquisadores que participaram da experiência e fizeram medições in loco na época do contrução.

\section{Emissões}

Quais as emissões atmosféricas? Identificar unidade e quantidade e origem.

As emissões atmosféricas são as proveinentes de queima de combustíveis fósseis para o transporte da matéria prima até a marcenaria. Não há qualquer outro tipo de emissão atmosférica.

Quais as emissões para água? Identificar unidade e quantidade e origem.

Não há emissões para a água nesse processo elementar.

Quais as emissões para o solo? Identificar unidade e quantidade e origem.

São as provenientes de uma fossa negra, que são originadas do banheiro do escritório da marcenaria. Não foi possível quantificar a quantidade e composição da emissão.

Qual é a fonte, período e data da amostragem dos dados fornecidos?

A fonte dos dados foi o regate dos registros, entre 2004 e 2006, dos pesquisadores que participaram da experiência e fizeram medições in loco na época do contrução e observação direta o levantamento.

Transporte (rod., fer., etc):

Nome do produto intermediário

madeira de Pinus de $3^{\text {a }}$ qualidade

\begin{tabular}{|l|l|l|l|}
\hline Dist. $(\mathrm{Km})$ & Capacidade & Carga real & retorno vazio? \\
\hline $27 \mathrm{~km}$ & 44 toneladas & 44 ton. & sim \\
\hline & & & \\
\hline & & & \\
\hline & & & \\
\hline
\end{tabular}

\section{Energia}

Qual o consumo de energia nesse processo elementar (elétrica, combustível fóssil, etc)? Identificar: unidades, quantidades, origem e destino.

O consumo médio de energia elétrica da marcenaria é de $345 \mathrm{KWh} /$ mês, e é utilizado para toda parte de escritório e consumo energético das máquinas que fazem parte desse processo. Como a produtividade foi de $39,91 \mathrm{~m}^{3}$ de componentes pré-fabricados por mês, tem-se que o consumo de energia elétrica foi de 8,64 KWh de energia elétrica por $\mathrm{m}^{3}$ de componente pré-fabricado. Também foi consumida a energia referente ao poder calorífico de diesel consumido para o transporte, 0,6746 litros para cada metro cúbico de madeira serrada transportada.

Qual é a fonte, período e data da amostragem dos dados fornecidos?

As fontes dos dados foram as três últimas contas de energia da marcenaria, no período 
de 2007, o controlo de produtividade feito durante a assessoria dos pesquisadores em 2004 e 2005, e o consumo médio de óleo diesel segundo BARTHOLOMEU (2006).

\section{Água}

Qual o consumo de água nesse processo elementar?

Identificar: unidades, quantidades, origem e destino.

O consumo de água nesse processo é de 1500 litros por mês, que é utilizado somente

na parte administrativa da marcenaria.

Qual é a fonte, período e data da amostragem dos dados fornecidos?

A fonte dos dados foi uma entrevista feita com os membros da marcenaria em julho de 2007.

\section{Observações}




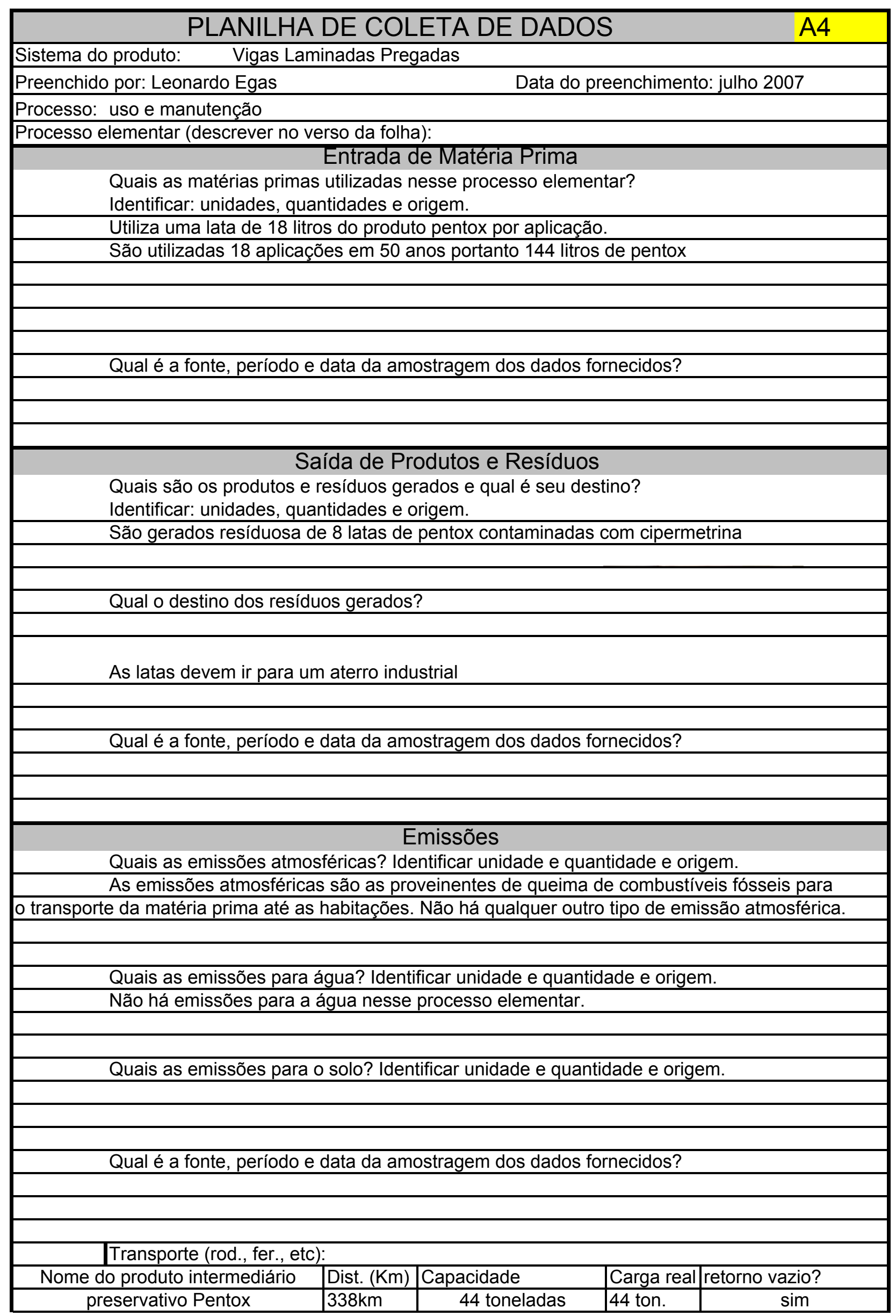




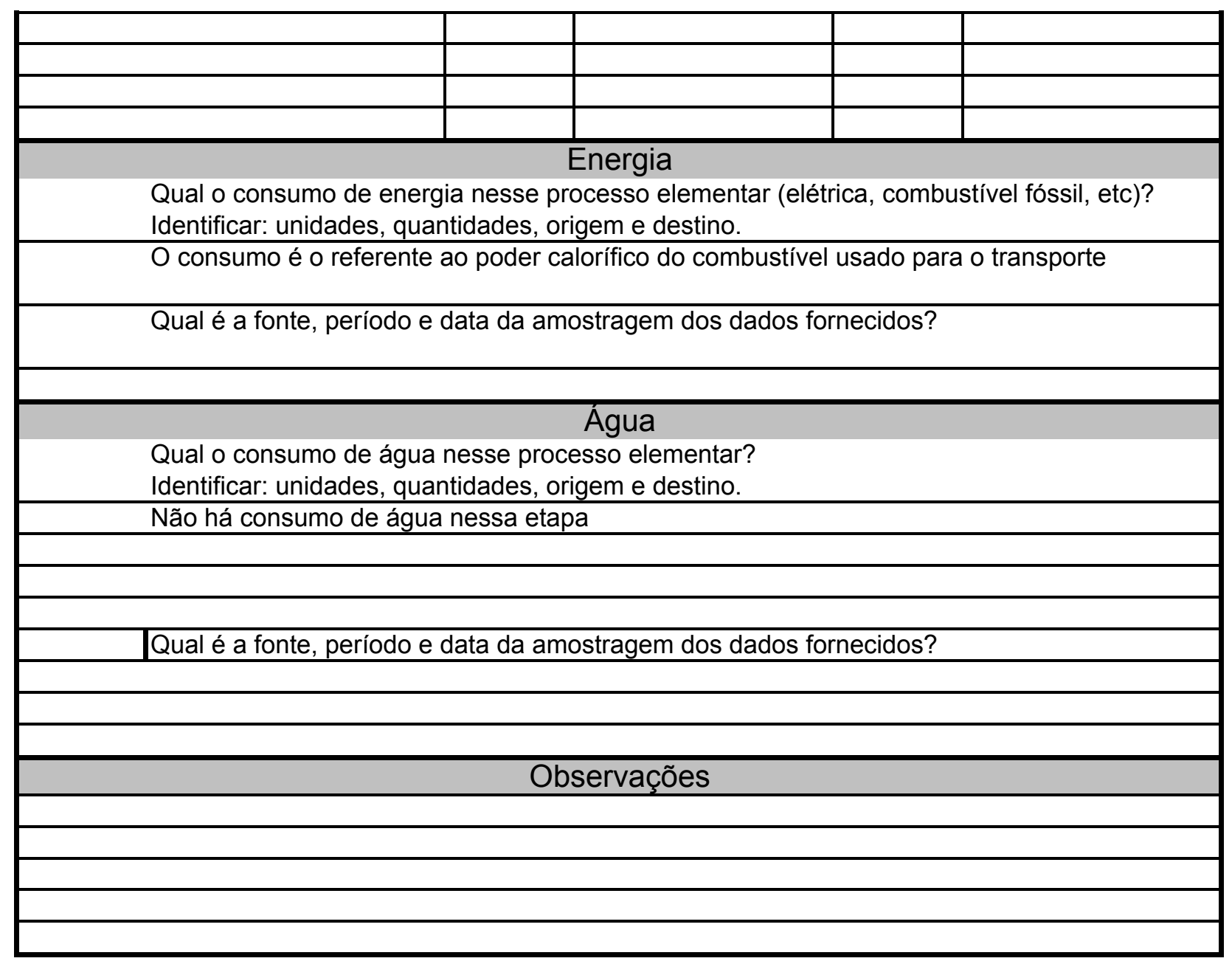




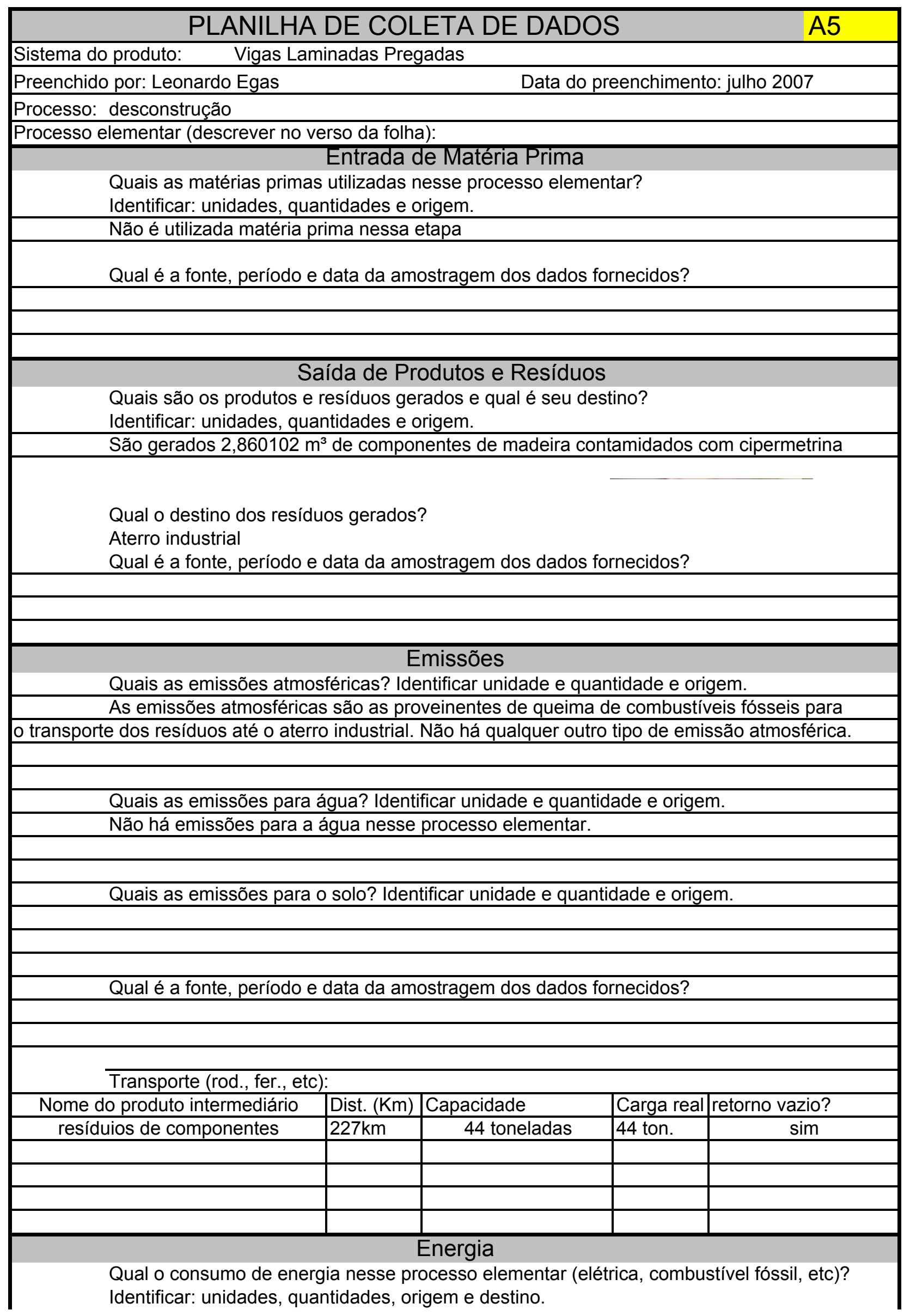




\begin{tabular}{|c|}
\hline O consumo é o referente ao poder calorífico do combustível usado para o transporte \\
\hline Qual é a fonte, período e data da amostragem dos dados fornecidos? \\
\hline Água \\
\hline $\begin{array}{c}\text { Qual o consumo de água nesse processo elementar? } \\
\text { Identificar: unidades, quantidades, origem e destino. }\end{array}$ \\
\hline Não há consumo de água nessa etapa \\
\hline \\
\hline Qual é a fonte, período e data da amostragem dos dados fornecidos? \\
\hline \\
\hline Observações \\
\hline \\
\hline \\
\hline \\
\hline \\
\hline
\end{tabular}




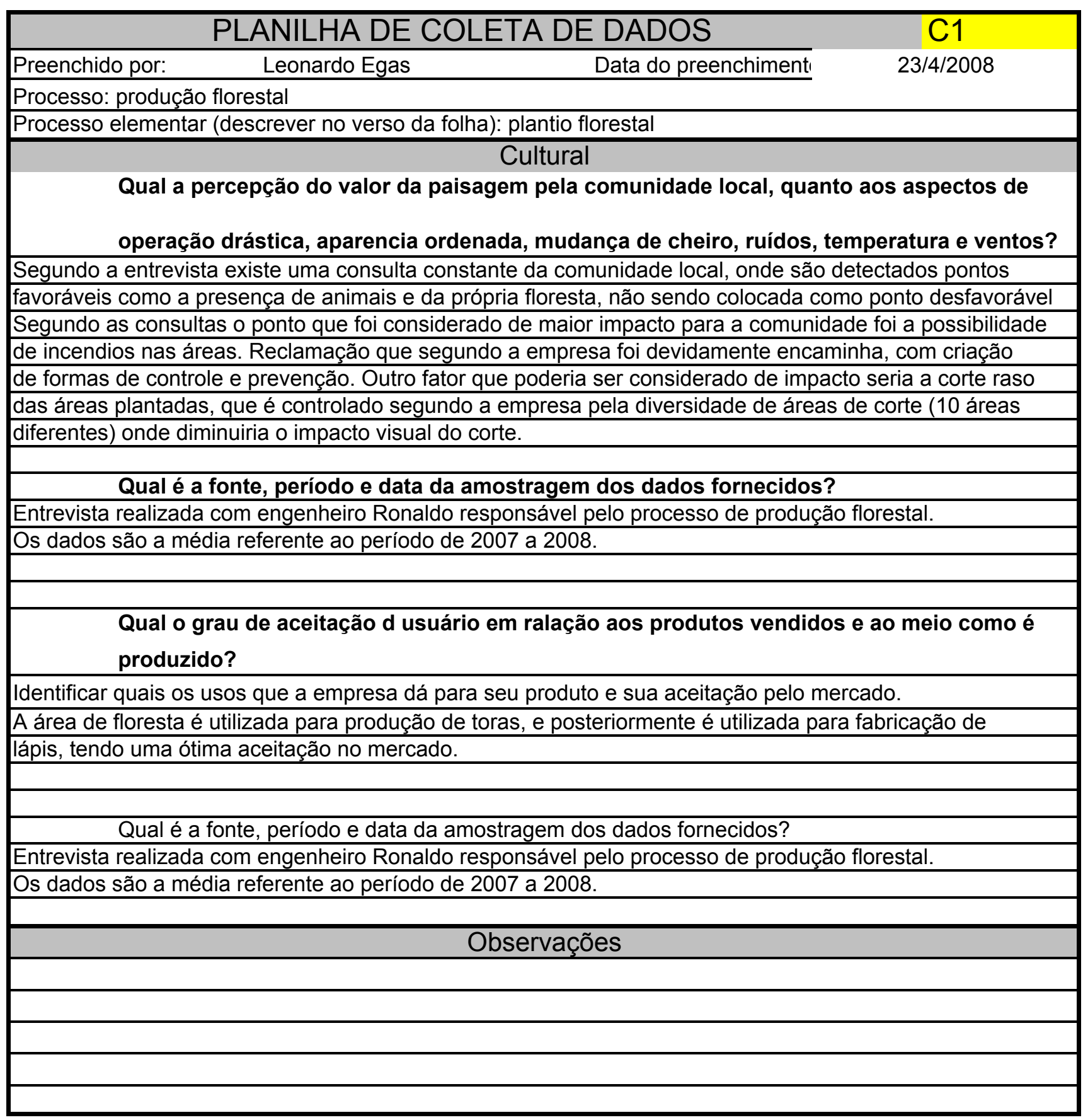




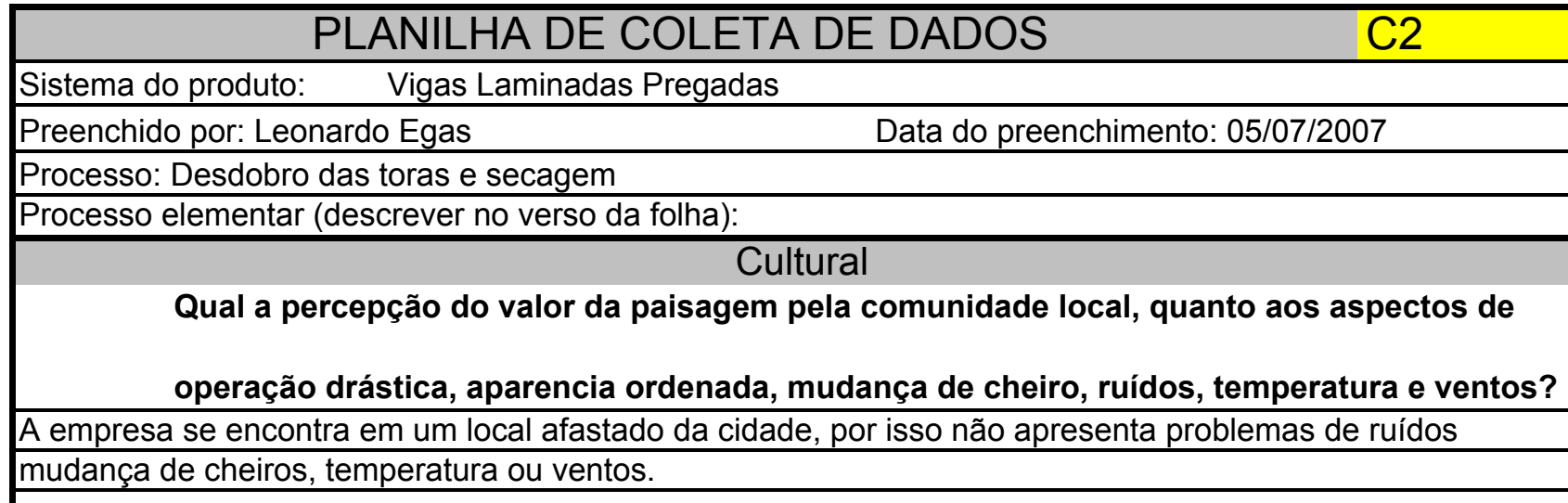

\begin{tabular}{|l|}
\hline \\
\hline \\
\hline \\
\hline Qual é a fonte, período e data da amostragem dos dados fornecidos? \\
\hline Entrevista com o gerende de produção das serrarias. A data da amostragem foi de fevereiro a \\
\hline junho de2007. \\
\hline \\
\hline Qual o grau de aceitação d usuário em ralação aos produtos vendidos e ao meio como é \\
\hline produzido? \\
\hline Os produtos vendidos são consagrados do mercado, como madeira de Pinus para embalagem ou \\
\hline caixaria na construção civil, e peças para indústria moveleira. Não havendo assim baixa aceitação por \\
\hline parte do mercado ou dos compradores desses produtos. \\
\hline \\
\hline Qual é a fonte, período e data da amostragem dos dados fornecidos? \\
\hline junho de2007. \\
\hline \\
\hline \\
\hline \\
\hline \\
\hline \\
\hline \\
\hline \\
\hline
\end{tabular}




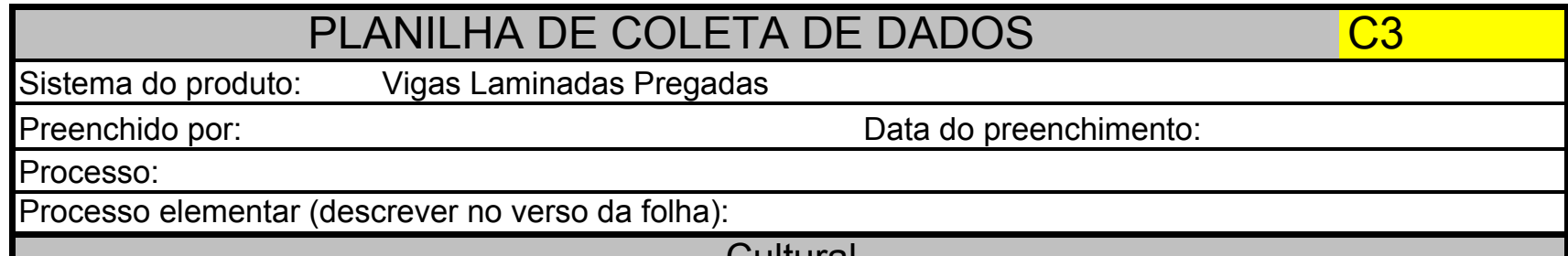

\section{Cultural}

Qual a percepção do valor da paisagem pela comunidade local, quanto aos aspectos de operação drástica, aparencia ordenada, mudança de cheiro, ruídos, temperatura e ventos?

A opinião da comunidade local foi positiva quanto a criação da amrcenaria, única infria-estrutura necessária para a produção, não causando nenhum grande impacto, visto que a edificação necessária já estava construida. Como a edifício fica a aproximadamente $2 \mathrm{~km}$ das habitações mais próximas não há problemas com os ruidos geradospela marcenaria.

Qual é a fonte, período e data da amostragem dos dados fornecidos?

Entrevista com integrantes damarcenaria em julho de 2007.

Qual o grau de aceitação d usuário em ralação aos produtos vendidos e ao meio como é produzido?

Das 49 casas para quem foram oferecidas a possibilidade de utilização do sistema de cobertura em vigas laminads pregadas, 36 aceitaram a sua utilização. Esse número reflete uma aceitaçaão de $73 \%$.

Qual é a fonte, período e data da amostragem dos dados fornecidos?

Entrevista com integrantes damarcenaria em julho de 2007 e dados coletados durante a fase de escolha dos materiais construtivos.

\section{Observações}




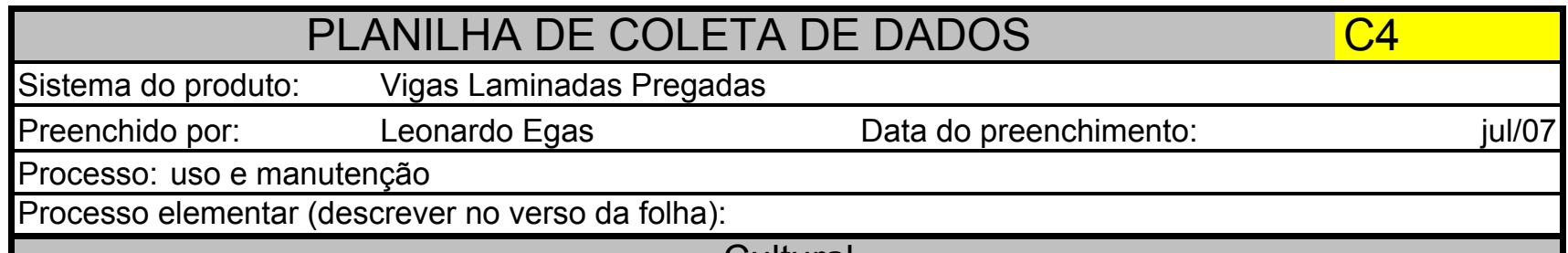

\section{Cultural}

Qual a percepção do valor da paisagem pela comunidade local, quanto aos aspectos de operação drástica, aparencia ordenada, mudança de cheiro, ruídos, temperatura e ventos?

A aprarencia final do sistema é identica ao sistema convencional, por isso teve uma grande aceitação dos usuários.

Qual é a fonte, período e data da amostragem dos dados fornecidos?

Qual o grau de aceitação d usuário em ralação aos produtos vendidos e ao meio como é produzido?

Através de relatos pode se perceber que a utilização desse sistema estrutural não cousou nenhum grau de rejeição nos usuários. A manutenção ainda não feita, devido ao curto periodo após a instalação, e só poderá ser analisada culturalmente após ser realizado.

Qual é a fonte, período e data da amostragem dos dados fornecidos?

\section{Observações}




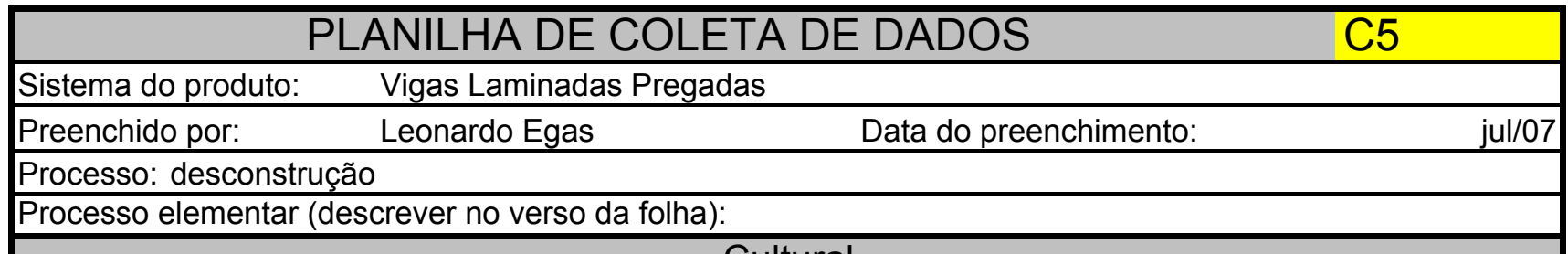

\section{Cultural}

Qual a percepção do valor da paisagem pela comunidade local, quanto aos aspectos de operação drástica, aparencia ordenada, mudança de cheiro, ruídos, temperatura e ventos? Esse ponto não foi discutido com as famílias.

Qual é a fonte, período e data da amostragem dos dados fornecidos?

Qual o grau de aceitação d usuário em ralação aos produtos vendidos e ao meio como é produzido?

Esse ponto não foi discutido com as famílias.

Qual é a fonte, período e data da amostragem dos dados fornecidos?

\section{Observações}




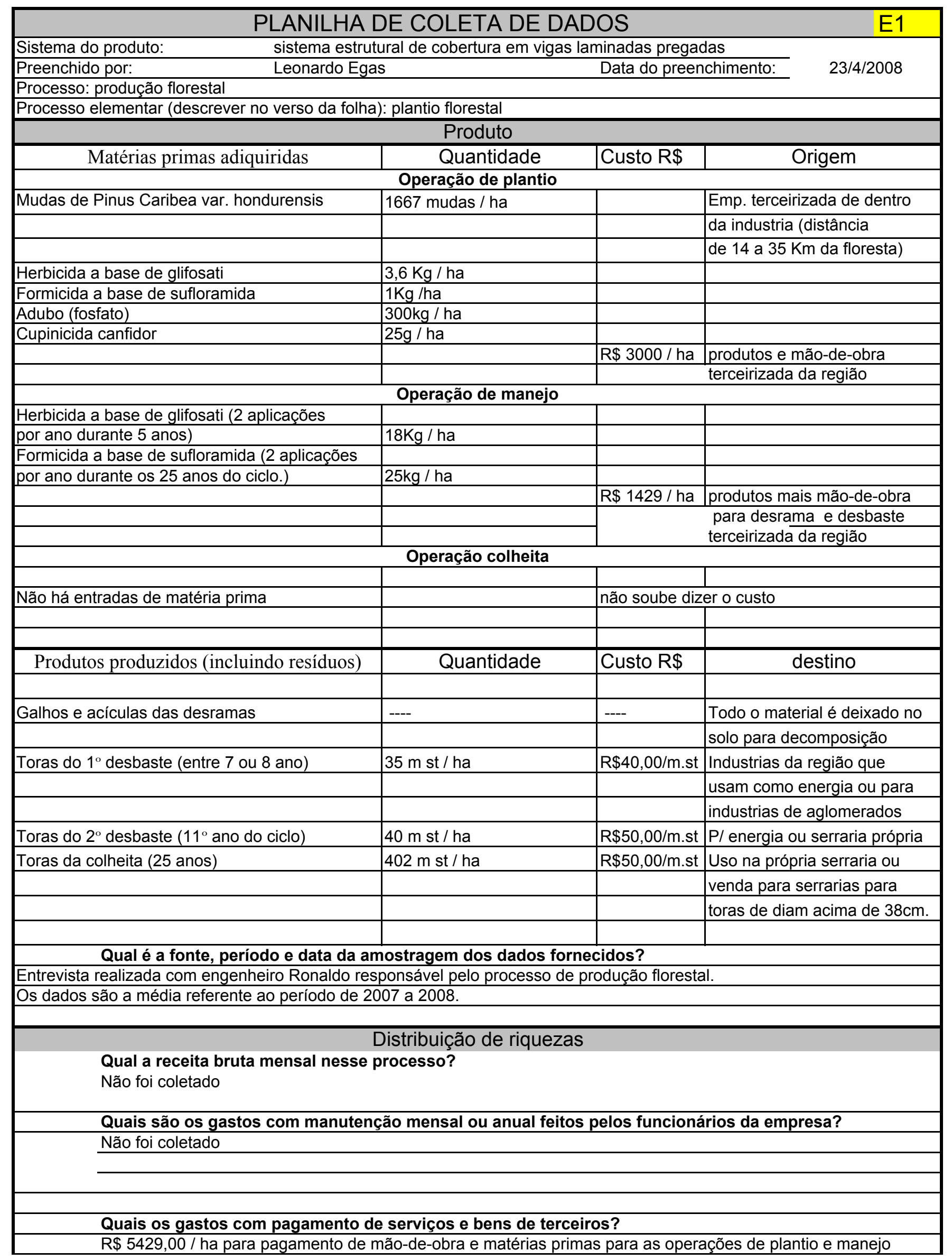


Quais os gastos com pagamento de impostos ao governo?

dado não coletado

\author{
Quais os gastos com os empregados? \\ Salário \\ Encargos previdenciários \\ Benefícios \\ Participação nos resultados \\ Quais os gastos com financiadores? \\ Quais os gastos com acionistas?
}

Qual é lucro retido?

Existe endividamento (financiamento, empréstimo, etc)?

Quais os lucros com receitas financeiras? Se houver.

Portanto a receita liquida é de $=\quad$ A renda líquida, somando-se os lucros retido, de receitra financeira,

Qual é a fonte, período e data da amostragem dos dados fornecidos?

\title{
Investimentos
}

Qual é o investimento em pesquisa e desenvolvimento mais sustentável?

A empresa possui um setor especializado em pesquisas que estuda melhorias dentro das seguintes áreas Solo: estudos de sistema de cultívo mínimo, controle e prevenção de processos erosivos, monitoramento e correção nutricional

Água: estudos para conservação da mata ciliar, análises físico-químicas dos corpos d'água (coleta de 4 amostras por ano tendo 54 parâmetros), padrões rígidos para cruzamento de cursos d'água.

Flora: Demarcação e proteção das áreas de preserva'vão permanente, projetos de recuperação da biodiversidade e preservação permanentek convênio com IEF para trocas de mudas (6 de Pinus por 1 nativa), pesquina de metodologia para restauração de áreas de reserva legal ocupadas atualmente por Pinus, controle mecanico da infestação do Pinus e áreas adjacentes.

Fauna: Monitoramento populacional da fauna de aves e mamiferos presentes nos parques florestais à 12 anos

Fogo: Proteção contra aceiros, consicentização de vizinhos, detecção através de torres e vigilância motorizada Combate pela brigada de incêndio, registro de estatísticas.

A empresa possui certificados de qualidade ambiental como o ISO 14001 e o FSC (certificado reconhecido

internacionalmente na área de plantios e manejo florestal) procurando garantir a qualidade ambiental de seus produtos.

Qual é o investimento na procura de uma maior produtividade?

Criação de um pomar de de sementes clonal próprio, estudo de espécies mais produtivas. Também possui estudos quanto a adubação e controle de pragas.

Qual é o investimento na procura de um aumento na capacidade produtiva?

A emrpesa que antes trabalhava com áreas de plantio florestal terceirizadas já investiu na compra de áreas próprias, paraprodução florestal. 
Qual é o investimento na educação e treinamento de funcionários?

Todos os funcionários passam por treinamento quanto a segurança no trabalho regularmente, além de terem treinamentos de educação ambiental anualmente. Também são oferecidos treinamentos de reciclagem dos funcionários .

Qual é o investimento em programas de auxílio a comunidade?

Além de doações regulares deprodutos para a comunidade a empresa participa de projetos de educação ambiental para a comunidade local, capacitando multiplicadores nas escolas públicas além de oferecer cursos de linguas e música para crianças carentes.

Qual é a fonte, período e data da amostragem dos dados fornecidos?

Entrevista realizada com engenheiro Ronaldo responsável pelo processo de produção florestal. Os dados são a média referente ao período de 2007 a 2008.

\begin{tabular}{|l|c|}
\hline Distribuição de riquezas \\
\hline Custo operacional & $\mathrm{R} \$ 123.182 .000,00$ \\
\hline Pagamento de funcionários & $\mathrm{R} \$ 104.533 .000,00$ \\
\hline Benefícios dos funcionários & $\mathrm{R} \$ 41.039 .000,00$ \\
\hline Impostos & $\mathrm{R} \$ 38.950 .000,00$ \\
\hline Contr. Comunidade & $\mathrm{R} \$ 788.000,00$ \\
\hline Proj. meioambiente & $\mathrm{R} \$ 3.531 .000,00$ \\
\hline lucro operacional & $\mathrm{R} \$ 40.650 .000,00$ \\
\hline Total ou Receita Liquida & $\mathrm{R} \$ 352.673 .000,00$ \\
\hline
\end{tabular}

Distribuição de riquezas

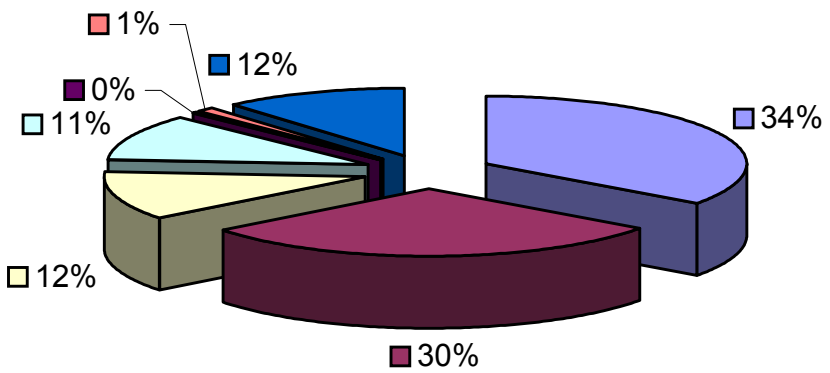

\begin{tabular}{|l|}
\hline Custo operacional \\
$\square$ Pagamento de funcionários \\
$\square$ Benefícios dos funcionários \\
$\square$ Impostos \\
$\square$ Contr. Comunidade \\
$\square$ Proj. meioambiente \\
$\square$ lucro operacional
\end{tabular}




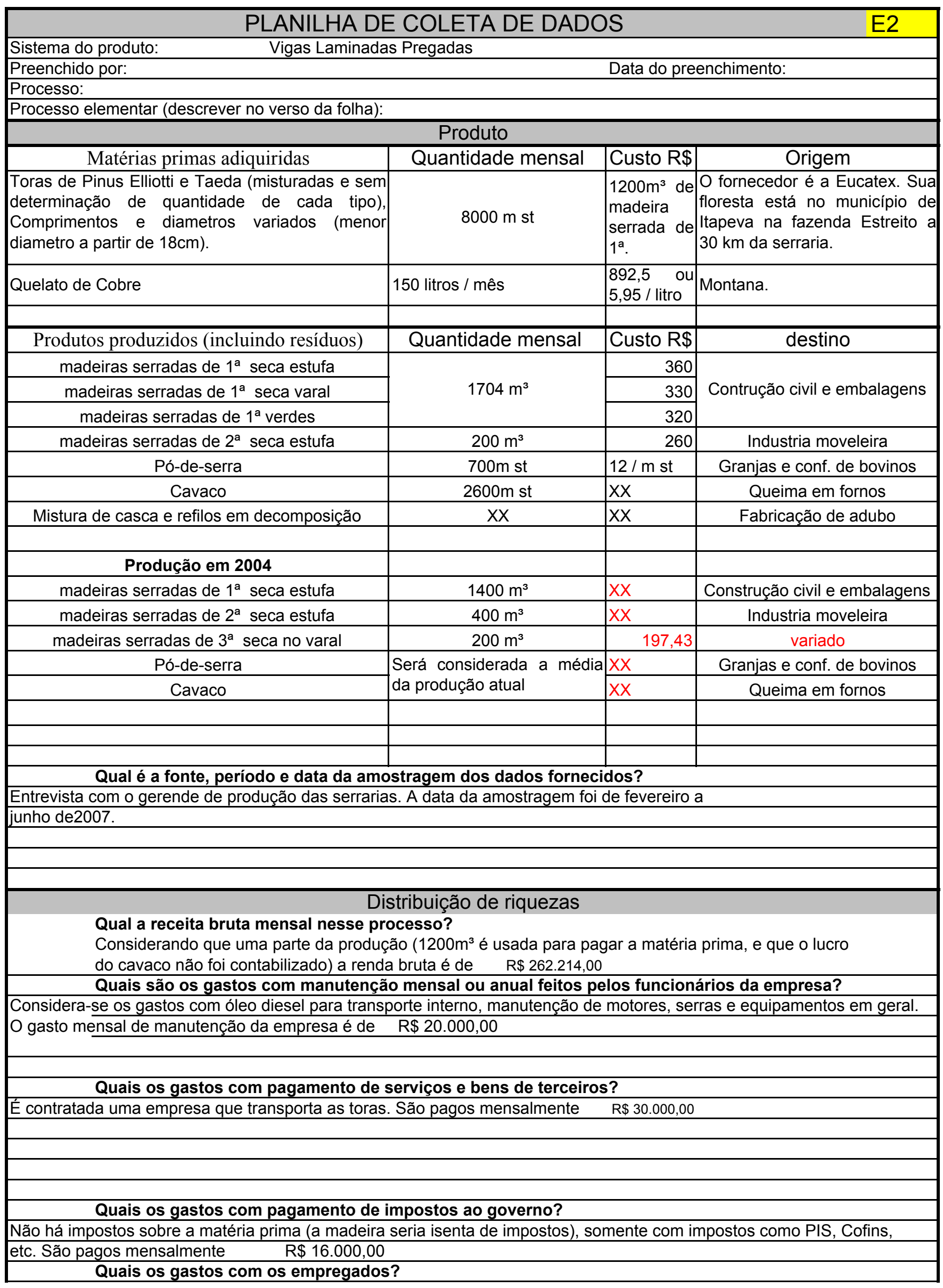


Salário

Encargos previdenciários

Benefícios

Participação nos resultados
$\mathrm{R} \$ 64.000$

dentro da folha de pagamento

Os trabalhadores têm benefício de transporte (próprio da empresa)

sexta básica e plano de saúde privado.

Os funcionários não têm participação nos resultados

Quais os gastos com financiadores?

Informação não coletada

Quais os gastos com acionistas?

Informação não coletada

Qual é lucro retido?

Informação não coletada

Existe endividamento (financiamento, empréstimo, etc)?

Informação não coletada

Quais os lucros com receitas financeiras? Se houver.

Informação não coletada

Portanto a receita liquida é de $=$ A renda líquida, somando-se os lucros retido, de receitra financeira, gastos com acionistas, financiadores e pagamento de emprestimos é de $\mathrm{R} \$ 132.214$

Qual é a fonte, período e data da amostragem dos dados fornecidos?

Entrevista com o gerende de produção das serrarias. A data da amostragem foi de fevereiro a junho de2007.

\section{Investimentos}

Qual é o investimento em pesquisa e desenvolvimento mais sustentável?

Está sendo feita uma sisterna para captação de águas de chuva, para diminuir o uso do poço artesiano.

Também foi implementado o equipamento para fabricar o cavaco com os resíduos do desdobro (refilos e costaneiras e destopos) assim o resíduo agora serve como fonte energética para outros processos.

Qual é o investimento na procura de uma maior produtividade?

Foram feitas mudanças nos tipos de serra utilizadas para obter uma maior produtividade além de adoção de esterias rolantes para o transporte de alguns resíduos.

Qual é o investimento na procura de um aumento na capacidade produtiva?

Não houve investimento na capacidade produtiva pois o mercado madeireiro não está crescendo. Isso se deve ao câmbio do dollar que não está favorecendo a exportação, assim o mercado brasileiro está com sobra de madeira serrada, fazendo com que o preço caia.

Qual é o investimento na educação e treinamento de funcionários?

A empresa procura contratar empregados já capacitados. A procura de melhoria ou treinamento se dá informalmente através da observação dos funcinários durante o trabalho e orientações para melhorias.

Existe um treinamento feito com especialistas em engenharia do trabalho para orientações quanto à segurança no trabalho e prevenção de acidentes.

Qual é o investimento em programas de auxílio a comunidade?

A empresa possui uma fundação (Fundação Brancalhão) que atualmente tem um projeto chamado "Esperança" que cuida de crianças de até 15 anos, oferecendo alimentação e estudos. Também é oferecido assistência a população carente do entorno.

Qual é a fonte, período e data da amostragem dos dados fornecidos?

Entrevista com o gerende de produção das serrarias. A data da amostragem foi de fevereiro a junho de2007. 
Distribuição de riquezas

\begin{tabular}{|l|r|}
\hline Matéria Prima & $\mathrm{R} \$ 440.000,00$ \\
\hline
\end{tabular}

\begin{tabular}{ll}
\hline Lucro operacional (2 pr & $\mathrm{R} \$ 132.214$ \\
\hline
\end{tabular}

\begin{tabular}{|l|r|}
\hline Empregados (82) & $\mathrm{R} \$ 64.000$ \\
\hline
\end{tabular}

Pagamento de terceiro: $\mathrm{R} \$ 30.000,00$

\begin{tabular}{|l|l|}
\hline Manutenção & $\mathrm{R} \$ 20.000,00$ \\
\hline
\end{tabular}

\begin{tabular}{|l|r|}
\hline Impostos & $\mathrm{R} \$ 16.000,00$ \\
\hline
\end{tabular}

\begin{tabular}{|l|l|}
\hline renda bruta total & $\mathrm{R} \$ 682.214,00$ \\
\hline
\end{tabular}

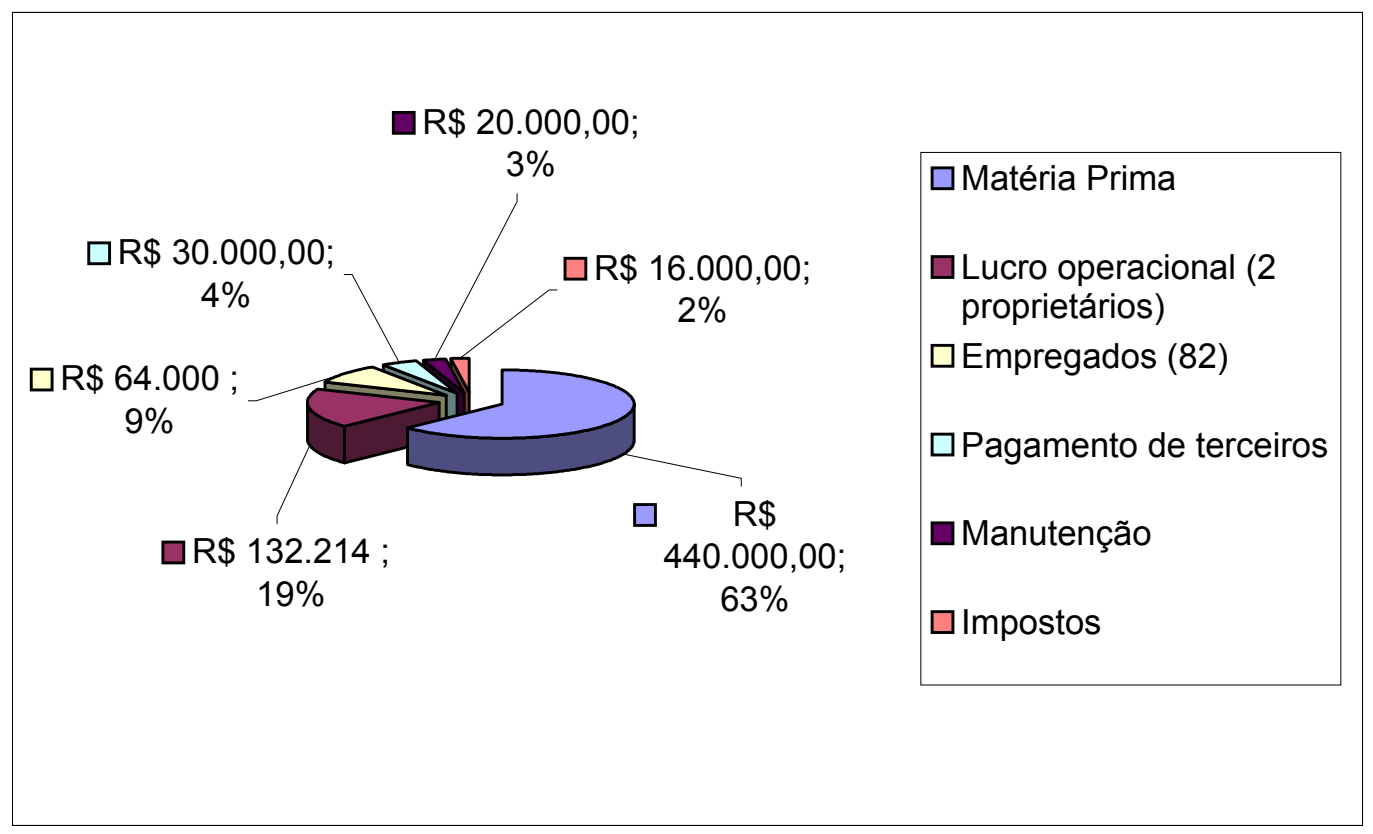




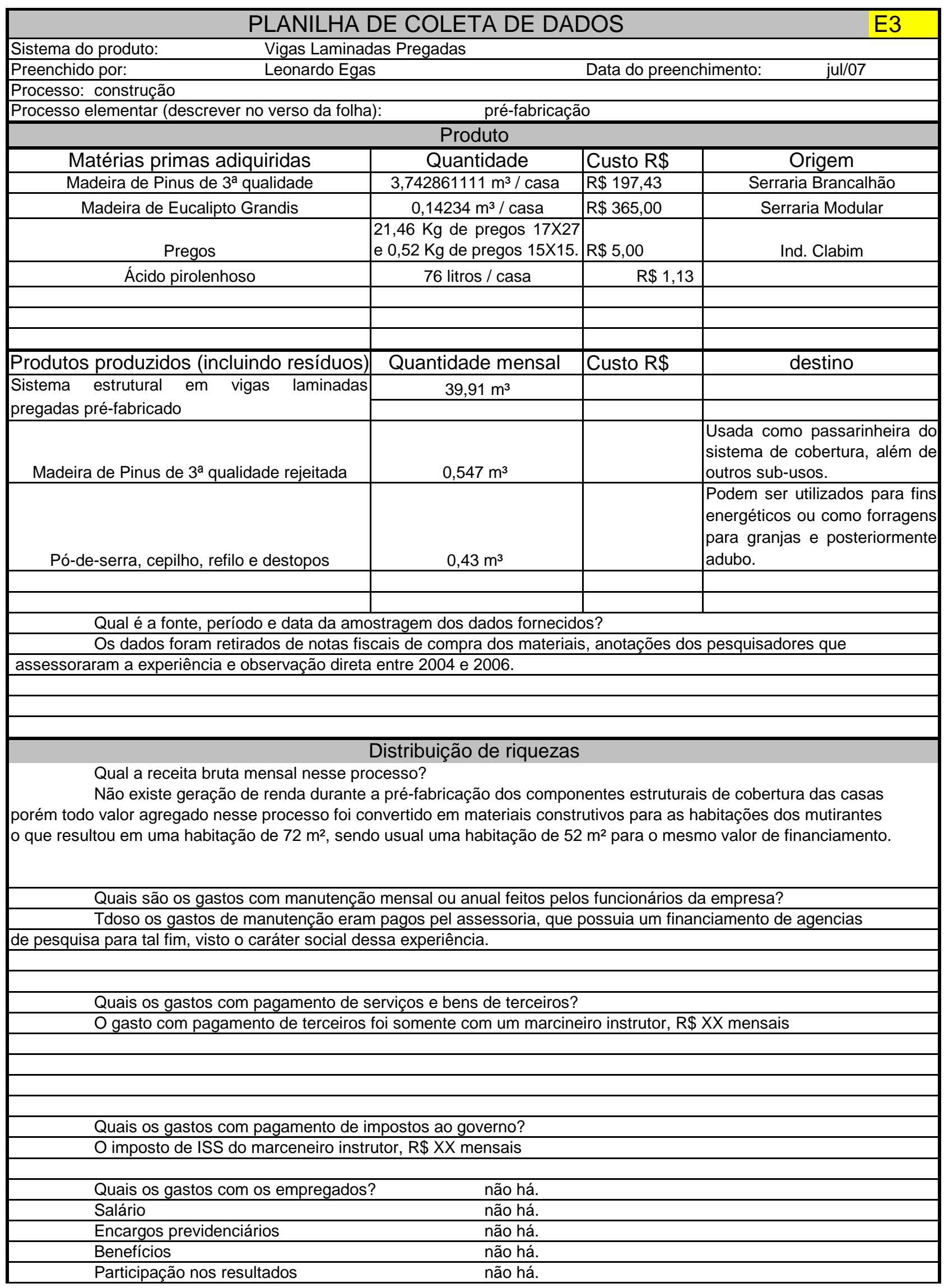




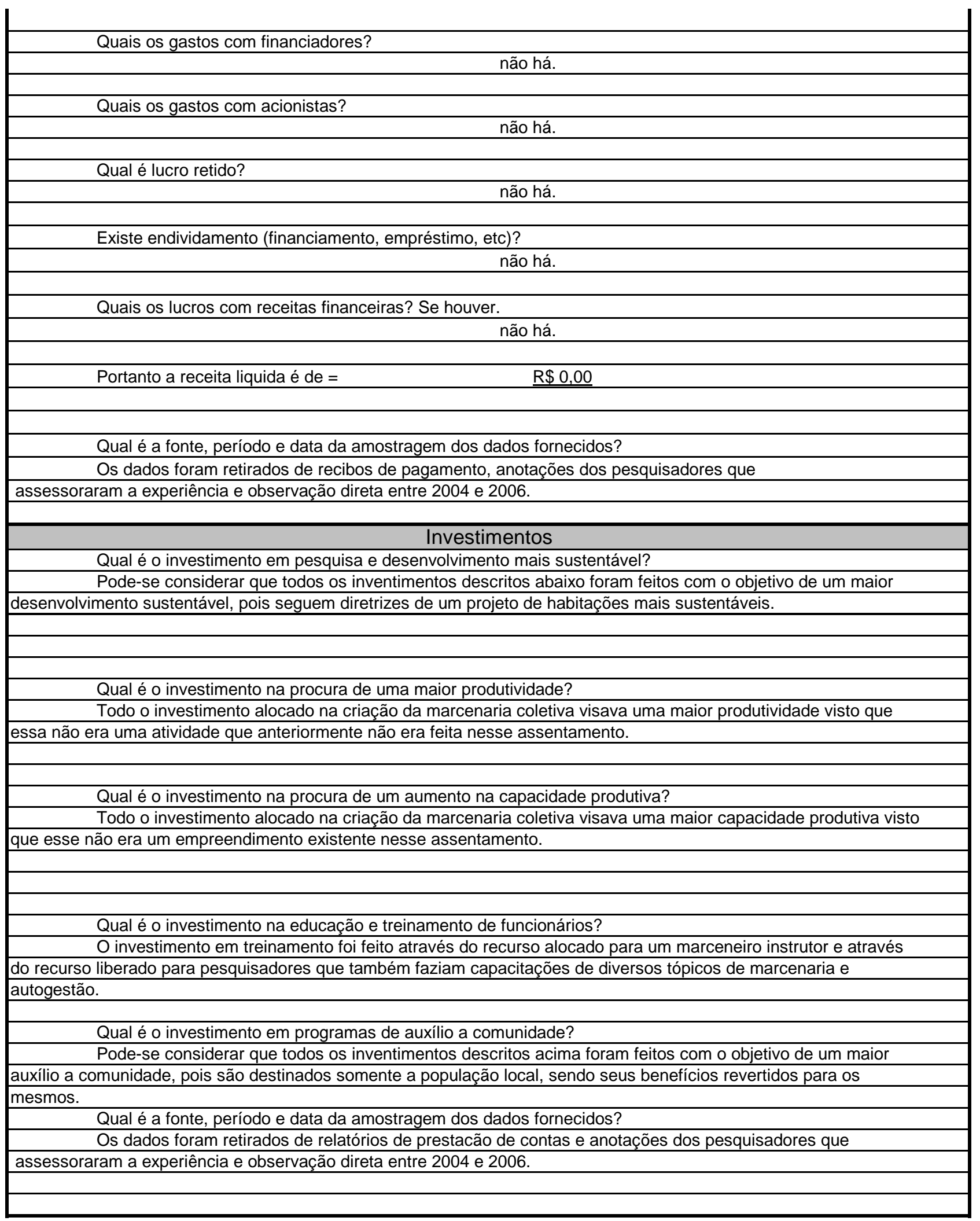




\begin{tabular}{|l|l|l|l|}
\hline \multicolumn{4}{|l|}{ Distribuição de riquezas } \\
\hline material & Quantidade & Preço unit. & total parcial \\
\hline Madeira de pinus & 3,612001 & $\mathrm{R} \$ 197,43$ & $\mathrm{R} \$ 713,12$ \\
\hline Madeira de eucalipto & 0,14234 & $\mathrm{R} \$ 365,00$ & $\mathrm{R} \$ 51,95$ \\
\hline Pregos & 21,98 & $\mathrm{R} \$ 5,00$ & $\mathrm{R} \$ 109,90$ \\
\hline Cabo de aço & 36 & $\mathrm{R} \$ 0,41$ & $\mathrm{R} \$ 14,76$ \\
\hline chapa de aço & 12 & $\mathrm{R} \$ 1,00$ & $\mathrm{R} \$ 12,00$ \\
\hline clips de aço & 6 & $\mathrm{R} \$ 0,32$ & $\mathrm{R} \$ 1,92$ \\
\hline tratamento pentox & 1 & $\mathrm{R} \$ 102,67$ & $\mathrm{R} \$ 102,67$ \\
\hline tratamento \\
pirolenhoso & 76 & $\mathrm{R} \$ 1,13$ & $\mathrm{R} \$ 85,50$ \\
\hline Parafusos & 35 & $\mathrm{R} \$ 0,61$ & $\mathrm{R} \$ 21,35$ \\
\hline total de materiais & total & $\mathrm{R} \$ 1.113,17$ \\
\hline manutenção & & $\mathrm{R} \$ 300,00$ \\
\hline assessoria & & $\mathrm{R} \$ 6.300,00$ \\
\hline
\end{tabular}

\section{Composição de custos do sistema VLP}

$\mathrm{R} \$ 102,67$

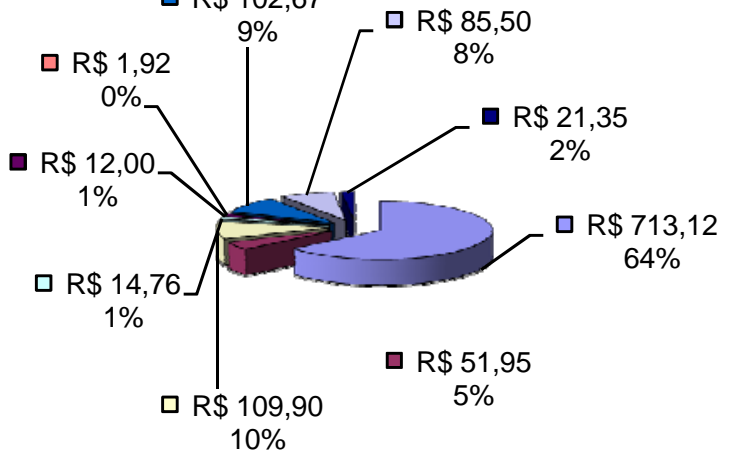

口Madeira de pinus

$\square$ Madeira de eucalipto

口Pregos

-Cabo de aço

-chapa de aço

口clips de aço

口tratamento pentox

口tratamento pirolenhoso

- Parafusos

\begin{tabular}{|l|r|}
\hline \multicolumn{2}{|l|}{ Custos do sist. durante o ciclo de vida } \\
\hline materiais construtivos & $\mathrm{R} \$ 1.113,17$ \\
\hline tratamento preservativo & $\mathrm{R} \$ 102,67$ \\
\hline manutenção & $\mathrm{R} \$ 821,36$ \\
\hline desconstrução & $\mathrm{R} \$ 0,00$ \\
\hline
\end{tabular}

custo ao longo do ciclo de vida

ㅁ $\mathrm{R} \$ 821,36 ;$

$\mathrm{R} \$ 0,00 ; 0 \%$ $40 \%$

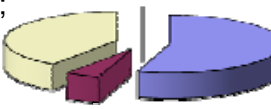

ㅁ $\mathrm{R} \$ 102,67 ; 5 \%$
ㅁ R\$ 1.113,17; $55 \%$ 口materiais construtivos

tratamento preservativo

口manutenção

口desconstrução 


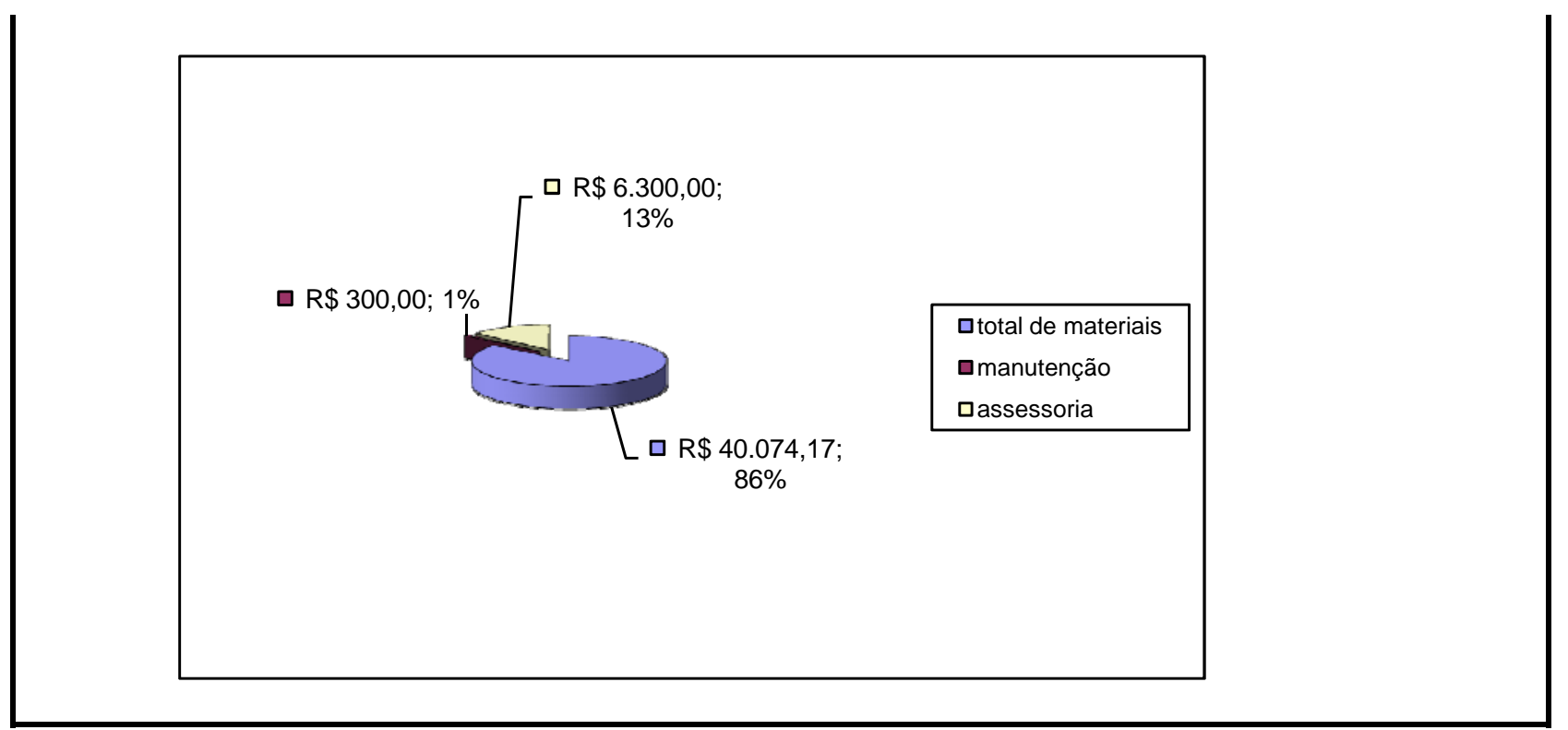




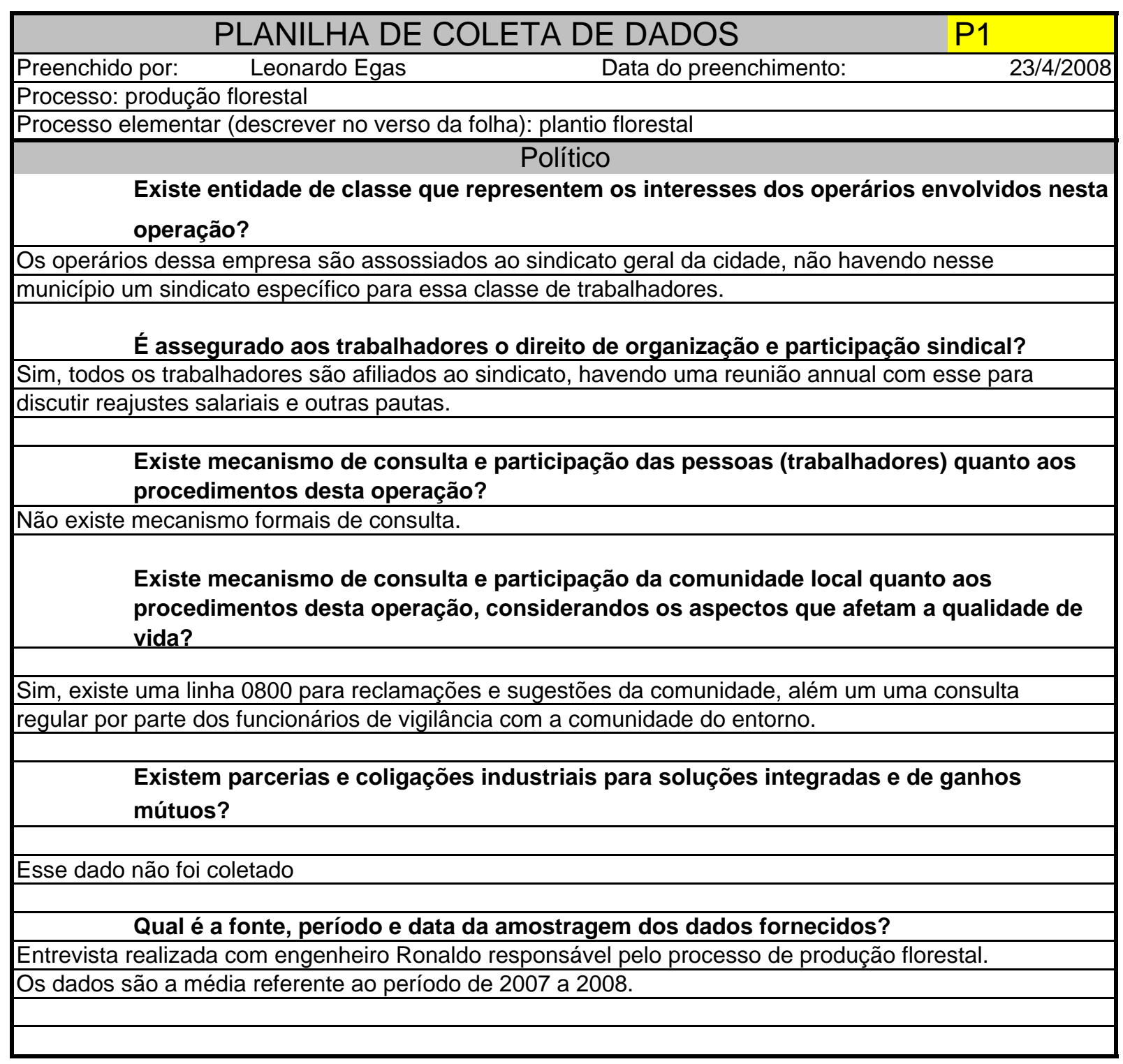




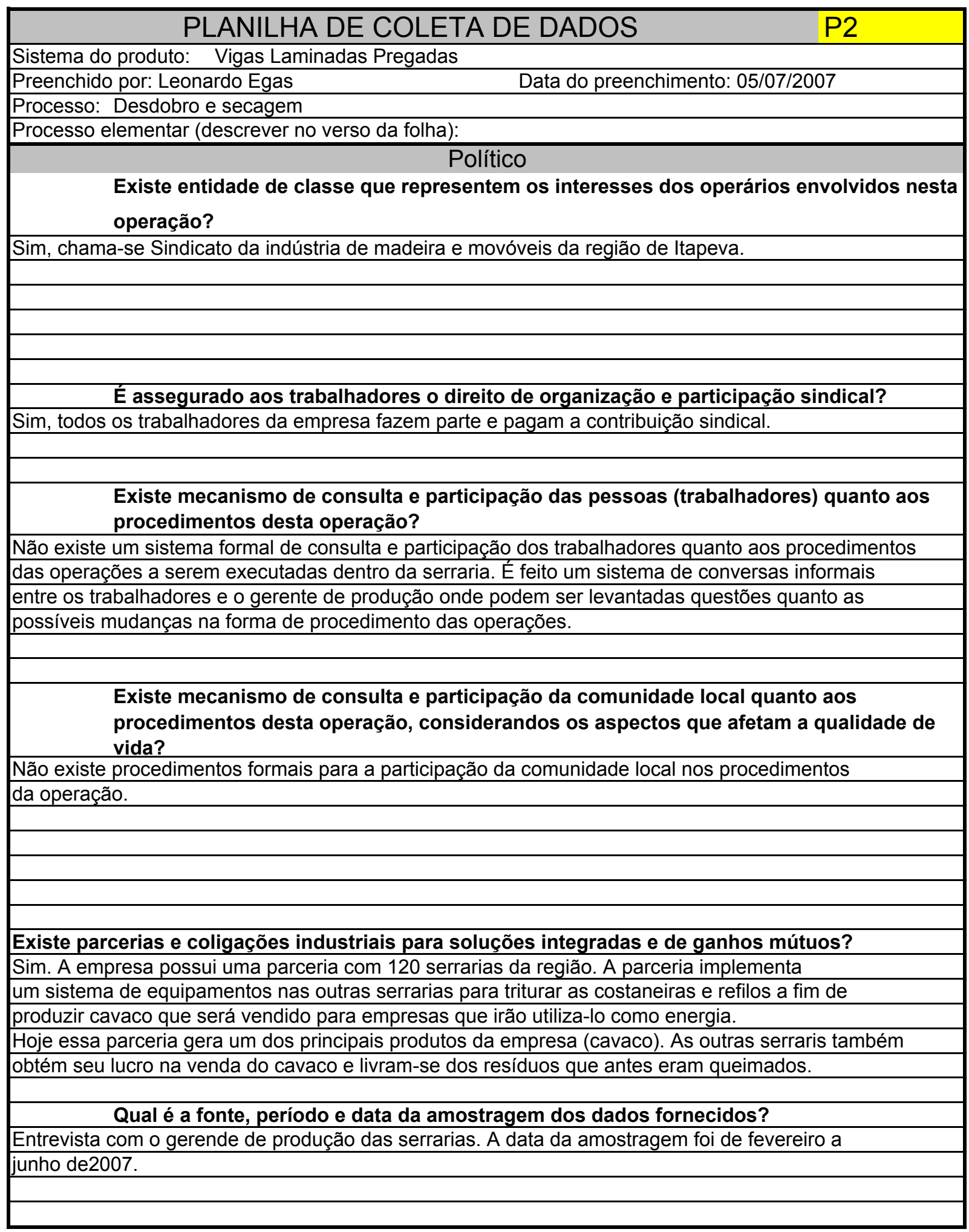




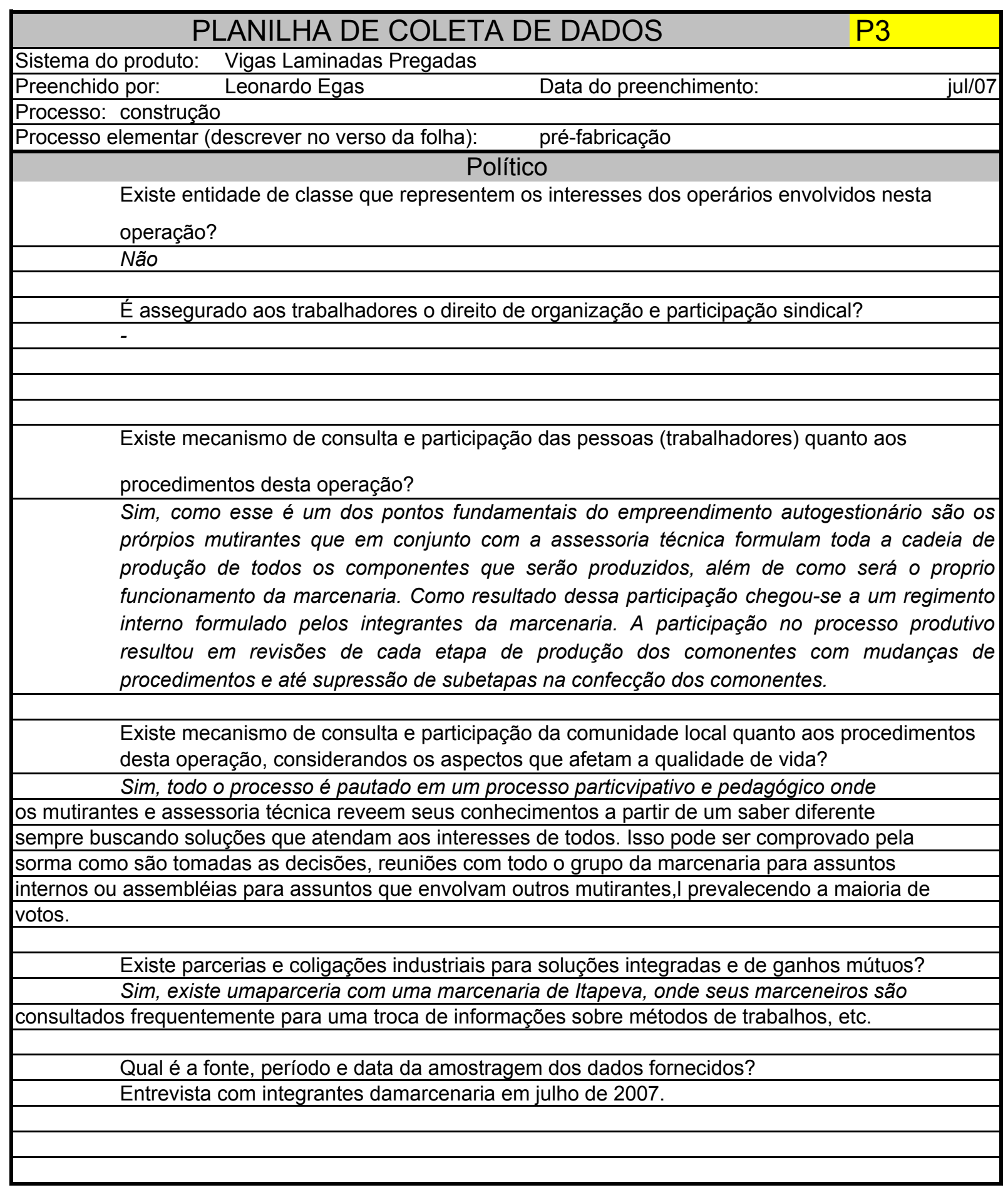




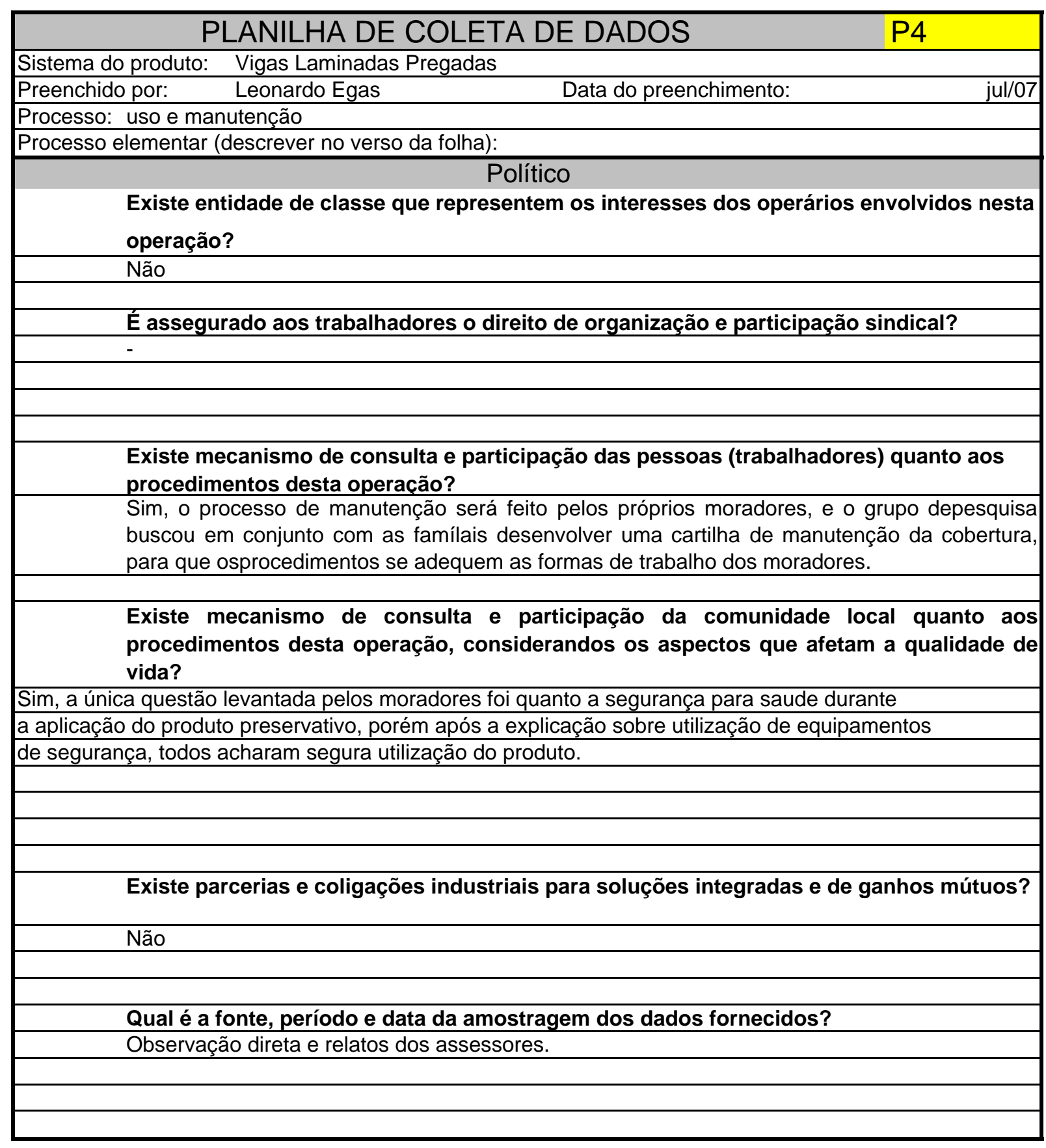




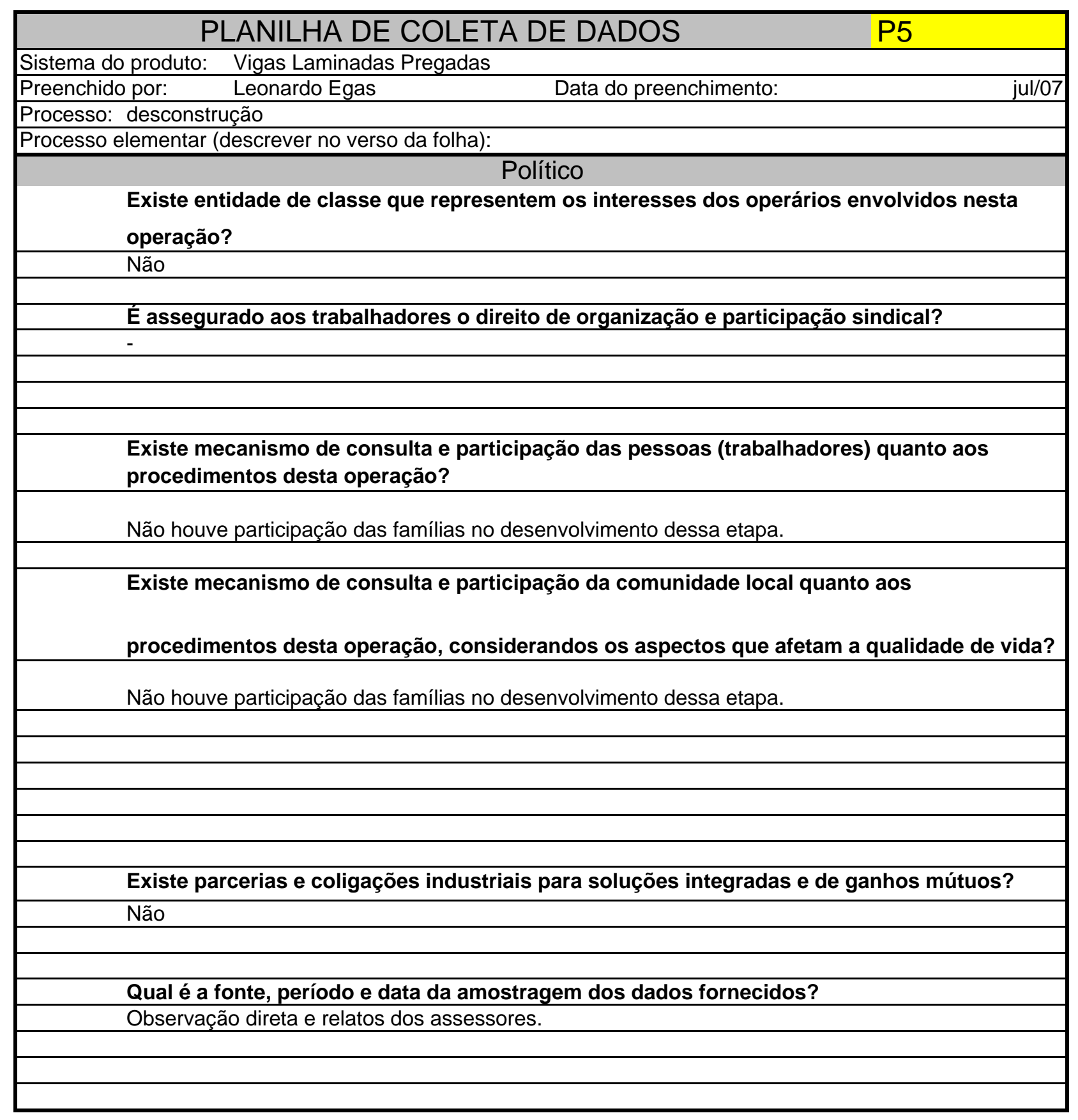

